\title{
WestVirginiaUniversity
}

THE RESEARCH REPOSITORY @ WVU

Graduate Theses, Dissertations, and Problem Reports

2001

\section{Ante- and post-mortem factors affect muscle protein functionality from fish}

Sitima Jittinandana

West Virginia University

Follow this and additional works at: https://researchrepository.wvu.edu/etd

\section{Recommended Citation}

Jittinandana, Sitima, "Ante- and post-mortem factors affect muscle protein functionality from fish" (2001). Graduate Theses, Dissertations, and Problem Reports. 1393.

https://researchrepository.wvu.edu/etd/1393

This Dissertation is protected by copyright and/or related rights. It has been brought to you by the The Research Repository @ WVU with permission from the rights-holder(s). You are free to use this Dissertation in any way that is permitted by the copyright and related rights legislation that applies to your use. For other uses you must obtain permission from the rights-holder(s) directly, unless additional rights are indicated by a Creative Commons license in the record and/ or on the work itself. This Dissertation has been accepted for inclusion in WVU Graduate Theses, Dissertations, and Problem Reports collection by an authorized administrator of The Research Repository @ WVU.

For more information, please contact researchrepository@mail.wvu.edu. 


\title{
ANTE- AND POST-MORTEM FACTORS \\ AFFECT MUSCLE PROTEIN FUNCTIONALITY FROM FISH
}

\author{
Sitima Jittinandana \\ Dissertation submitted to the \\ College of Agriculture, Forestry, and Consumer Sciences \\ at West Virginia University \\ in partial fulfillment of the requirements \\ for the degree of
}

Doctor of Philosophy

in

Animal and Food Sciences

P. Brett Kenney, Ph.D., Chair

Mary Head, Ph.D., R.D.

Patricia Mazik, Ph.D.

Kenneth Semmens, Ph.D.

William Thayne, Ph.D.

Division of Animal and Veterinary Sciences

Morgantown, West Virginia

2001

Keywords: brining protocol, smoked fish, handling stress, frozen storage, cryoprotection, muscle quality 


\section{ABSTRACT \\ Ante- and Post-mortem Factors Affect Muscle Protein Functionality from Fish}

\section{Sitima Jittinandana}

Rainbow trout, Oncorhynchus mykiss, fillets were brined in 8.7 or $17.4 \%$ $(\mathrm{w} / \mathrm{v})$ sodium chloride solution, respectively, for $30,60,90$, or $120 \mathrm{~min}$ at $3^{\circ} \mathrm{C}$. Increased brine concentration decreased brined pH, myosin solubility, brined and cooked moisture content, and water activity, and increased fillet weight loss after brining, cook yield, actin solubility, water-phase salt content, and shear force. Brining time linearly increased myofibrillar protein solubility, fillet weight loss after brining, water-phase salt content, and cooked ash content and linearly decreased water activity and brined and cooked moisture content. An $8.7 \%(\mathrm{w} / \mathrm{v})$ brine and 90-min brining time resulted in maximum texture development while achieving the water-phase salt content $(\geq 3.5 \%)$ required by the Food and Drug Administration.

For ante-mortem handling stress, Arctic charr, Salvelinus alpinus, hatched at 6.5 and $9.5^{\circ} \mathrm{C}$ and categorized as large, medium, and small when 6-m old, were assigned to four handling stress treatments: 1) processing with no stress; 2 ) processing immediately after stress; 3) processing $24 \mathrm{~h}$ after stress, and 4) processing $48 \mathrm{~h}$ after stress. Stress reduced gut weight and muscle $\mathrm{a}^{*}$, increased $L^{*}$ for the $9.5^{\circ} \mathrm{C}$ group, decreased $L^{*}$ for the $6.5^{\circ} \mathrm{C}$ group, and increased fillet weight loss after brining. Fish hatched at $9.5^{\circ} \mathrm{C}$ appeared to be more sensitive to handling stress; fillets from the stressed, $9.5^{\circ} \mathrm{C}$ group absorbed more brine, increasing salt and ash content of smoked products. Resting for 48 $h$ after stress increased gut weight and enhanced $L^{*}$.

Poorer texture quality was observed in smoked products produced from frozen fillets. Stabilization of rainbow trout fillets by water, $1 \%(\mathrm{w} / \mathrm{v})$ sodium lactate, or $8 \%(\mathrm{w} / \mathrm{v})$ sucrose/sorbitol $(1: 1 \mathrm{w} / \mathrm{w})$, alone or in combination with $0.5 \%$ $(\mathrm{w} / \mathrm{v})$ sodium tripolyphosphate/tetrasodium pyrophosphate $(1: 1 \mathrm{w} / \mathrm{w})$ and/or $0.05 \%(\mathrm{w} / \mathrm{v})$ magnesium chloride was investigated. Cryoprotectants minimized the negative effects of $90-\mathrm{d}$ frozen storage at $-20^{\circ} \mathrm{C}$ on total and myofibrillar protein solubility, protein surface hydrophobicity, total, free and disulfide sulfhydryl content, and myosin susceptibility to thermal denaturation. Sucrose/sorbitol provided more effective cryoprotection than sodium lactate in preservation of protein structure and improvement of texture quality in smoked fillets. Phosphate enhanced cryoprotective effect. Magnesium chloride tended to accelerate protein denaturation during frozen storage. 


\section{ACKNOWLEDGEMENTS}

I would like to express my sincerest gratitude to Dr. P. Brett Kenney for his professional guidance, encouragement, and allowing me to work independently during my Ph.D. program. I would like to thank my committee members Drs. Mary Head, Patricia Mazik, Kenneth Semmens, and William Thayne for their suggestions and constructive criticisms. I gratefully acknowledge the technical support offered by Susan Slider and Rodney Kiser. The support offered by Dr. Robert Diener, Resource Management, in availing the Instron Universal Testing Machine for the first and the second studies is greatly appreciated. I am thankful to Jeff Altermus, Department of Anatomy, for his efforts with gel image analysis. I am greatly indebted to Dr. Jim Mahaney, Biochemistry Department, for helping me out with the spectrofluorometer. I gratefully thank Dr. Ben Dawson-Andoh, Division of Forestry, for the differential scanning calorimeter. I thank the faculty, fellow graduate, and undergraduate students of the Division of Animal and Veterinary Sciences, College of Agriculture, Forestry, and Consumer Sciences, West Virginia University, and my colleagues at the Institute of Nutrition, Mahidol University for their support and encouragement.

I gratefully acknowledge the support of USDA/CSREES Special Aquaculture Grant, entitled "Aquaculture Food and Marketing Development Project" in this research. I specially thank the Ministry of Science, Technology, and Environment, Bangkok, Thailand for their financial support.

I would like to thank my parents, Dr. Anucha and Tongyou Jittinandana, for their encouragement. I also thank Somchoke Khunsanong for his love. 


\section{TABLE OF CONTENTS}

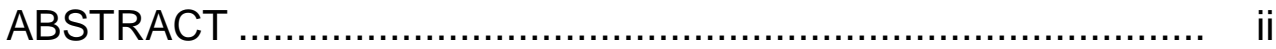

ACKNOWLEDGEMENTS ................................................... iii

TABLE OF CONTENTS …................................................. iv

LIST OF FIGURES ........................................................... vi

LIST OF TABLES ............................................................... viii

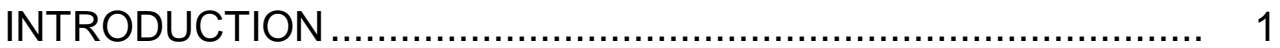

LITERATURE REVIEW

Smoked fish processing............................................... 3

Ante-mortem factors affecting fish protein characteristics... 12

Freezing and subsequent frozen storage ........................ 23

Cryoprotectants stabilization of protein ............................. 35

Antioxidants stabilization of protein................................ 40

References ....................................................... 43

CHAPTER 1 Effect of brine concentration and brining time on quality of smoked rainbow trout, Oncorhynchys mykiss, fillets

Abstract.............................................................. 54

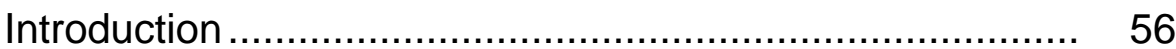

Materials and Methods ............................................ 57

Results and Discussion .......................................... 64

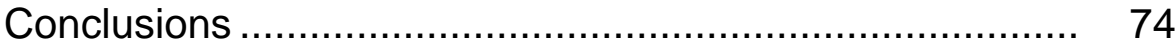

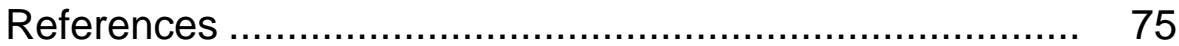

Appendix 1 Thermal processing schedule ........................ 91

Appendix 2 Statistical program ...................................... 92

CHAPTER 2 Effect of handling stress on muscle quality of smoked Arctic char, Salvelinus alpinus, fillets

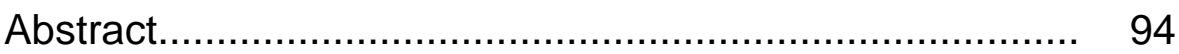

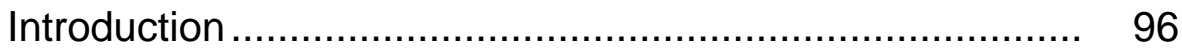

Materials and Methods ……....................................... 97

Results and Discussion

Hatching temperature ............................................... 103

Size category ....................................................... 104

Ante-mortem handling stress .................................. 108 
Hatching temperature and stress interaction ............. 110

Conclusions .............................................................. 114

References …................................................. 115

Appendix 1 Numbers of fish, average fish weight, and biomass after size grading ............................. 127

Appendix 2 Numbers of fish in each treatment combination 128

Appendix 3 Numbers of fillet in each thickness group ....... 129

Appendix 4 Fork length, whole body weight, fillet weight and thickness, and gender of fish in each main plot

Appendix 5 Statistical programs ................................... 131

CHAPTER 3 Frozen storage and cryoprotection effects on physicochemical attributes of intact rainbow trout, Oncorhynchus mykiss, fillets and the quality of smoked products

Abstract

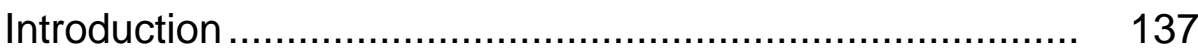

Materials and Methods ............................................... 139

Results and Discussion ............................................ 148

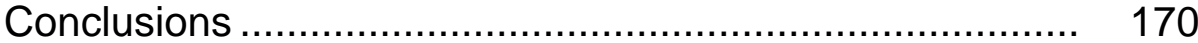

References ................................................................ 173

Appendix 1 Preliminary study: Chemical and physical changes in smoked rainbow trout, Oncorhynchus mykiss, associated with frozen storage........................ 229

Appendix 2 Soluble myofibrillar proteins ........................... 235

Appendix 3 Aliphatic protein surface hydrophobicity........... 237

Appendix 4 Free and total sulfhydryl content .................... 239

Appendix 5 Total myosin............................................. 242

Appendix 6 Differential scanning calorimeter program ....... 244

Appendix 7 Endogenous protease activity ......................... 245

Appendix 8 Statistical programs ...................................... 248

Appendix 9 Electrophoretic gel patterns of fish muscle protein from the no-soak control of fresh and frozen groups 


\section{LIST OF FIGURES}

\section{CHAPTER 1}

Figure 1 Myosin solubility patterns for 8.7 and $17.4 \%(\mathrm{w} / \mathrm{v})$ brine at different brining times

Figure 2 Mince cook yield patterns for 8.7 and $17.4 \%(\mathrm{w} / \mathrm{v})$ brine at different brining times.

Figure 3 Salt content patterns of smoked fillets for 8.7 and $17.4 \%(\mathrm{w} / \mathrm{v})$ brine at different brining times

Figure 4 Hardness patterns of cooked mince for 8.7 and $17.4 \%(\mathrm{w} / \mathrm{v})$ brine at different brining times

Figure 5 Cohesiveness patterns of cooked mince for 8.7 and $17.4 \%(\mathrm{w} / \mathrm{v})$ brine at different brining times

Figure 6 Electrophoretic gel patterns of fish muscle proteins for $8.7 \%(\mathrm{w} / \mathrm{v})$ brine at different brining times.

Figure 7 Electrophoretic gel patterns of fish muscle proteins for $17.4 \%(\mathrm{w} / \mathrm{v})$ brine at different brining times

\section{CHAPTER 3}

Figure 1 Means $\mathrm{pH}$ water, $1 \%(\mathrm{w} / \mathrm{v})$ sodium lactate (SL), and $8 \%(\mathrm{w} / \mathrm{v})$ sucrose/sorbitol $(1: 1 \mathrm{w} / \mathrm{w})$ solutions, alone or in combination with $0.5 \%(\mathrm{w} / \mathrm{v})$ phosphates and/or $0.05 \%(\mathrm{w} / \mathrm{v})$ magnesium chloride

Figure 2 Effect of cryoprotectant on solution uptake 181

Figure 3 Effect of $0.5 \%(\mathrm{w} / \mathrm{v})$ phosphate on solution uptake ...... 182

Figure 4 Effect of $0.05 \%(\mathrm{w} / \mathrm{v})$ magnesium chloride $\left(\mathrm{MgCl}_{2}\right)$ on solution uptake 183

Figure 5 Effect of cryoprotectant on fillet $\mathrm{pH}$ 184

Figure 6 Effect of cryoprotectant on total protein solubility ......... 185

Figure 7 Effect of cryoprotectant on myosin solubility .............. 186

Figure 8 Effect of cryoprotectant on total myosin ..................... 187 
Figure 9 Effect of cryoprotectant on actin solubility .................. 188

Figure 10 Effect of cryoprotectant on surface hydrophobicity....... 189

Figure 11 Effect of cryoprotectant on total sulfhydryl content....... 190

Figure 12 Effect of cryoprotectant on free sulfhydryl content ....... 191

Figure 13 Effect of cryoprotectant with or without $0.05 \%(\mathrm{w} / \mathrm{v})$ magnesium chloride $\left(\mathrm{MgCl}_{2}\right)$ on disulfide sulfide content 193

Figure 14 Effect of cryoprotectant on transition temperature of myosin.

Figure 15 Effect of cryoprotectant on transition temperature of actin

Figure 16 Effect of cryoprotectant on muscle endogenous protease activity

Figure 17 Effect of cryoprotectant on $L^{*}$ value 197

Figure 18 Effect of cryoprotectant on $a^{*}$ value 198

Figure 19 Effect of cryoprotectant on $b^{*}$ value 199

Figure 20 Effect of cryoprotectant on brine uptake 200

Figure 21 Effect of cryoprotectant on mince cook yield 201

Figure 22 Effect of cryoprotectant on fillet cook yield 202

Figure 23 Effect of cryoprotectant on cooked pH 203

Figure 24 Effect of cryoprotectant on salt content of smoked fillets 204

Figure 25 Effect of cryoprotectant on water-phase salt content of smoked fillets

Figure 26 Effect of cryoprotectant on hardness of cooked mince. 206

Figure 27 Effect of cryoprotectant on cohesiveness of cooked mince

Figure 28 Effect of cryoprotectant on fillet shear force. 208 


\section{LIST OF TABLES}

\section{CHAPTER 1}

Table 1 Brined $\mathrm{pH}$, cooked $\mathrm{pH}$, and total protein and actin solubility at various brine concentrations or brining times

Table 2 Estimated ionic strength in brined and cooked fillets at various brine concentrations and/or brining times... 79

Table 3 Brine uptake, fillet cook yield, water-phase salt content, water activity, and fillet shear force at various brine concentrations or brining times.

Table 4 Proximate composition of brined fillets at various brine concentrations or brining times

Table 5 Proximate composition of smoked fillets at various brine concentrations or brining times

\section{CHAPTER 2}

Table 1 Effect of hatching temperature on body characteristics, muscle $b^{*}$, and brine uptake.

Table 2 Effect of size category on body characteristics and muscle color

Table 3 Effect of size category on smoked fillet characteristics

Table 4 Effect of stress on body characteristics, muscle $b^{*}$, and brine uptake

Table 5 Hatching temperature by stress interaction for fillet weight, and muscle $L^{*}$ and $a^{*}$

Table 6 Hatching temperature by stress interaction for proximate composition on smoked fillets

Table $7 \quad$ Hatching temperature by stress interaction for smoked fillets characteristics

Table 8 Hatching temperature by stress interaction for color of smoked fillets 


\section{CHAPTER 3}

Table 1 Effect of frozen storage on physicochemical and quality attributes of intact fillets and smoked products from the no-soak control $(\alpha=0.05)$

Table 2 Effect of $0.5 \%(\mathrm{w} / \mathrm{v})$ phosphate on fillet $\mathrm{pH}$, total protein and myofibrillar protein solubility, and total myosin from fresh and frozen groups.

Table 3 Effect of $0.05 \%(\mathrm{w} / \mathrm{v})$ magnesium chloride $\left(\mathrm{MgCl}_{2}\right)$ on fillet $\mathrm{pH}$, total protein and myofibrillar protein solubility, and total myosin from fresh and frozen groups.

Table 4 Effect of $0.5 \%(\mathrm{w} / \mathrm{v})$ phosphate on surface hydrophobicity and total, free and, disulfide sulfhydryl (SH) content from fresh and frozen groups

Table 5 Effect of $0.05 \%(\mathrm{w} / \mathrm{v})$ magnesium chloride $\left(\mathrm{MgCl}_{2}\right)$ on surface hydrophobicity and total and free sulfhydryl $(\mathrm{SH})$ content from fresh and frozen groups.

Table 6 Effect of $0.5 \%(\mathrm{w} / \mathrm{v})$ phosphate on transition temperatures $\left(T_{M}\right)$ of myofibrillar proteins and endogenous protease activity from fresh and frozen groups

Table 7 Effect of $0.05 \%(\mathrm{w} / \mathrm{v})$ magnesium chloride $\left(\mathrm{MgCl}_{2}\right)$ on transition temperatures $\left(\mathrm{T}_{\mathrm{M}}\right)$ of myofibrillar proteins and endogenous protease activity from fresh and frozen groups

Table 8 Effect of $0.5 \%(\mathrm{w} / \mathrm{v})$ phosphate on muscle $\mathrm{L}^{*}, \mathrm{a}^{*}$, and $b^{*}$ values from fresh and frozen groups.

Table 9 Effect of $0.05 \%(\mathrm{w} / \mathrm{v})$ magnesium chloride $\left(\mathrm{MgCl}_{2}\right)$ on muscle $L^{*}, a^{*}$, and $b^{*}$ values from fresh and frozen groups

Table 10 Effect of $0.5 \%(\mathrm{w} / \mathrm{v})$ phosphate on brine uptake, mince and fillet cook yield, cooked $\mathrm{pH}$, and total and water-phase salt content from fresh and frozen groups 
Table 11 Effect of $0.05 \%(\mathrm{w} / \mathrm{v})$ magnesium chloride $\left(\mathrm{MgCl}_{2}\right)$ on brine uptake, mince and fillet cook yield, cooked $\mathrm{pH}$, and total and water-phase salt content from fresh and frozen groups.

Table 12 Effect of $0.5 \%(\mathrm{w} / \mathrm{v})$ phosphate on hardness and cohesiveness of cooked mince and fillet shear force from fresh and frozen groups

220

Table 13 Effect of $0.05 \%(\mathrm{w} / \mathrm{v})$ magnesium chloride (MgCl2) on hardness and cohesiveness of cooked mince and fillet shear force from fresh and frozen groups.....

Table 14 Effect of cryoprotectant on proximate composition of brined fillets produced from fresh and frozen groups..

222

Table 15 Effect of cryoprotectant on proximate composition of cooked fillets produced from fresh and frozen groups

223

Table 16 Effect of $0.5 \%(\mathrm{w} / \mathrm{v})$ phosphate on proximate composition of brined fillets produced from fresh and frozen groups

224

Table 17 Effect of $0.5 \%(\mathrm{w} / \mathrm{v})$ phosphate on proximate composition of cooked fillets produced from fresh and frozen groups

Table 18 Effect of $0.05 \%(\mathrm{w} / \mathrm{v})$ magnesium chloride $\left(\mathrm{MgCl}_{2}\right)$ on proximate composition of brined fillets produced from fresh and frozen groups

Table 19 Effect of $0.05 \%(\mathrm{w} / \mathrm{v})$ magnesium chloride $\left(\mathrm{MgCl}_{2}\right)$ on proximate composition of cooked fillets produced from fresh and frozen groups 


\section{INTRODUCTION}

Food fish production is poised to become an important aquaculture enterprise in the United States because of a decrease in the supply of wild caught fish while consumer demand continues to increase. Import to meet this increased demand contributes to increased trade deficit. Processed fish are sold to retail markets as fresh and frozen fillets. Curing and smoking can be used to add value to fish as a raw material for muscle foods. These technologies expand marketing opportunities for this raw material. In typical smoked fish processing, brine concentrations range from $15-24 \%(\mathrm{w} / \mathrm{v})$ salt; these concentrations promote dehydration of muscle proteins that, in turn, affects product palatability and acceptability. Insufficient salt concentration and temperature abuse during distribution may cause the germination of Clostridium botulinum spores followed by growth and toxin production in the food. The challenge associated with curing and smoking is the development of optimal texture at a water-phase salt content that would limit growth of spoilage and pathogenic organisms and comply with the Food and Drug Administration Guidelines.

Fish protein is very susceptible to denaturation that is associated with factors that may occur before and after death. The requirement for high quality raw products in the commercial market has stimulated many studies of the effects of stress physiology on post-mortem biochemical changes in muscle. Handling stress in the late ante-mortem period affects rate and extent of postmortem metabolism. Events of post-mortem metabolism can alter protein-protein and protein-water interactions that, in turn, affect protein functionality. Frozen 
storage is important in fish marketing, distribution, and inventory control. However, freeze-induced muscle protein denaturation and related functionality losses are commonly observed. Knowledge of ante- and post-mortem factors responsible for protein functionality loss would be useful to fish producers and processors for preserving protein quality. Use of cryoprotectants to preserve protein functionality may be useful for enhancing stability of intact fillets during frozen storage. Thus the work in this dissertation was addressed: 1) optimizing brining protocol of smoke processing, 2) evaluating effects of ante-mortem handling stress and resting period after stress on muscle and product quality, and 3) determining frozen storage effects and stabilizing effects of cryoprotectants on physicochemical attributes of myofibrillar proteins and quality of smoked products. 


\section{LITERATURE REVIEW}

\section{Smoked fish processing}

Value-added seafood products, such as smoked fish, are available because of unique appearance, texture, and flavor as well as prolonged shelf life and increased profit potential. Smoked fish production includes salting, partial dehydration, and impregnation of smoke components. The traditional process varies among countries. Variation exists in method of salting, concentration of salt, and smoking technique.

Salt (sodium chloride, $\mathrm{NaCl}$ ) is added to the product mainly to improve flavor. Salt also delays microbial spoilage and inhibits Clostridium botulinum Type E during storage. The mechanism whereby salt extends fish shelf life can be explained in terms of the effect of salt on the sorption isotherm and the consequent reduction of moisture content and water activity (Doe et al., 1982). The method of salting can be either dry salting, in which solid salt is rubbed into the fish flesh, or brining. In brining, fish are soaked in a concentrated salt solution. In conventional brining techniques, brine concentration ranges from 15 to $24 \%(\mathrm{w} / \mathrm{v})$ sodium chloride and length of exposure to salt varies from 0.5 to 48 h (Wooton and Ismail, 1986).

Various smoking procedures have been developed. In general, there are principally three smoking protocols: 1) cold smoking at a temperature not exceeding $30^{\circ} \mathrm{C}, 2$ ) hot smoking that causes thermal denaturation of the proteins,

and 3) hot smoke-drying (jerky-like processing) in which thin fish strips are dried and then smoked for only a portion of the drying time. These dehydrated strips 
do not need refrigeration (Doe et al., 1982). Hot smoking requires a short processing time compared to cold smoking. In the heating stage of hot smoking, water evaporation occurs and reduces product moisture content. Smoking gives an appealing smoked flavor and color, and it contributes to preservation. The most important smoked flavor components are phenols. Color characteristics depend on skin pigmentation, quantity and composition of smoke deposits, and their interactions with the tissue. In addition, the skin of hot-smoked fatty fish acquires a characteristic gloss formed by the thin layer of rendered fat. In lean species, the gloss appears if the fish is fresh during brining and some of proteins dissolve in the brine and cover the skin. Bacterial inhibition in smoked fish is attributable to salt and smoke compounds (primarily formaldehyde and phenolic substances), drying, and heating. However, a properly hot-smoked product has a moist consistency and is subject to spoilage. The finished products require refrigeration.

Microbial spoilage of smoked fish

Fish contain microorganisms on the skin and in the gut. Contamination of fish muscle by a wide range of microorganisms occurs during production, transportation, and processing. Improper brining, smoking, packaging, and storage temperature are the major causes of spoilage and foodborne diseases linked to these products.

The largest outbreak of botulism associated with fishery products occurred in smoked whitefish chubs processed in the Great Lakes region (Anonymous, 1963). These fish had low levels of salt, did not contain nitrite, and were 
temperature abused during distribution. This outbreak was caused by $C$. botulinum Type $\mathrm{E}$ and resulted in 9 deaths out of 16 cases. Between 1899 and 1977 , there have been a total of 41 recorded botulism outbreaks caused by fish products. Only 15 outbreaks have occurred from meat products (beef, poultry, and pork) during the same period (Center for Disease Control, 1979). Heinitz and Johnson (1998) reported the incidence of Listeria spp., Salmonella spp., and C. botulinum in smoked fish of different countries from 1991 to $1995 . \quad L$. monocytogenes was isolated from $14 \%$ of 1,080 samples and was higher in coldsmoked products than in hot-smoked samples. Salmonella were isolated from $3.2 \%$ of 156 samples, and C. botulinum spores were not detected in any of the 201 vacuum packed samples.

Guidelines for smoked fish

Investigations on the prevention of toxin production by $C$. botulinum Type E have shown that toxin formation by survivors in smoked fish was dependent on salt content of the smoked fish (Christiansen et al., 1968). A water-phase salt of at least $3 \%$ in the product inhibits spore outgrowth and toxin production. Taking into account incomplete spore inactivation during heating and the possibility of post-processing contamination, a water-phase salt content of at least $3 \%$ throughout the fish should prevent botulism.

Food and Drug Administration Guidelines consider a smoked seafood product in violation if $L$. monocytogenes, Salmonella spp., or preformed C. botulinum toxin is detected (Food and Drug Administration, 1997). Guidelines also consider a product in violation if $C$. botulinum Type $E$ spores are detected 
and the water-phase salt or nitrite level are insufficient; noncompliance contributes to potential toxin production. Water-phase salt guidelines vary depending on smoke processing, packaging, and use of nitrites. Hot-processed, smoked fish require heating to a temperature of at least $62.8^{\circ} \mathrm{C}$ throughout each fish and holding at this temperature for a minimum of $30 \mathrm{~min}$. For vacuum packaged, hot- or cold-smoked fish, and for air-packaged, cold-smoked product, water-phase salt in the dorsal musculature of finished product must be at least $3.5 \%$ when no nitrites are used and at least $3.0 \%$ with at least $100 \mathrm{ppm}$ nitrite. For aerobically packaged, hot-smoked product, water-phase salt must be at least $3.0 \%$ with or without nitrite. Nitrite is permitted in smoked salmon, sable fish, and shad as long as it does not exceed 200 ppm. The antimicrobial mechanism of nitrite is unknown, but it has been suggested that nitrite reacts with sulfhydryl groups to create compounds that are not metabolized by microorganisms under anaerobic conditions (Lindsay, 1996).

\section{Brining techniques}

Christiansen and coworkers (1968) pointed out that, to attain a minimum of $3 \%$ water-phase salt in any part of the smoked product, average water-phase salt for the whole fish must be higher than this figure. Thinner sections of the fish usually have a very high salt content. Variations in thickness contribute to saltiness and dryness in products brined to give $3 \%$ water-phase salt using conventional brining techniques. Non-uniform salt distribution and excessive salt in some sections result in a commercially unacceptable smoked-fish product. 
It is difficult to achieve uniform sodium chloride concentrations in large batches of fish or in parts of the same fish during brining operations. Rate of salt uptake depends on many factors including species, dimension of fish, weight, muscle thickness, muscle characteristics, composition, physiological state, salting method, brine concentration, brining time, and fish-to-salt ratio. Lautenschlager (1985) concluded that sodium chloride diffusion through pork, $M$. longissimus dorsi, was a slowly running process, primarily affected by meat composition and structure, storage, and handling factors. They reported that brine concentration, $\mathrm{pH}$, and temperature had no remarkable influence on salt diffusion. Rubbing or massaging salt into the muscular part of the meat surface can accelerate salt diffusion. Eklund and coworkers (1982) developed a brining step for hot-smoked Chum salmon, Oncorhynchus keta, in regard to timing. After brining, fish steaks were rinsed with fresh water and held in plastic bags for $1 \mathrm{~d}$ at $3.3^{\circ} \mathrm{C}$ before heat processing. Prolonged refrigerated brining and additional storage resulted in uniform distribution of sodium chloride.

Kosak and Toledo (1981) demonstrated a two-stage brining procedure to minimize differences in water-phase salt between thin and thick sections of 1 to 2-Ib mullet, Mugel cephalus, after hot smoking. The objective of the first stage in this procedure is to allow salt penetration into the thickest portion of the fish, while minimizing variation in salt concentration. Because the fillet has variable thickness, thicker sections of the fish reach salt levels and thinner sections become over-salted. The objective of the second stage in the brining procedure is to leach out salt in over-salted areas. The first stage involved soaking in $10 \%$ 
sodium chloride for $15 \mathrm{~h}$ using 1 -lb fish at a fish to brine ratio of approximately 1 $\mathrm{lb}$ to $1 \mathrm{~L}$. This stage was followed by soaking in $2 \%$ sodium chloride for 24 to 48 h. They indicated that variation in weight and fish species may require different brining times to obtain results comparable to those reported in their paper. Kenney and coworkers (1997) studied a two-stage brining protocol of 285-g rainbow trout, Oncorhynchus mykiss, fillets by varying conditions of the first stage and holding the second stage at $2 \%$ sodium chloride for $24 \mathrm{~h}$. They found that brine concentration and brining time of the first stage affected salt content but had no effect on water activity.

Innovative salting techniques including vacuum sealing fish in plastic bags with salt, vacuum tumbling, and salt injection have been reported. Goeller and Lanier (2000) studied effects of vacuum and solute concentration on sorbitol infusion into intact trout muscle. They reported that vacuum did not consistently affect sorbitol uptake. They suggested that an injection method was a much faster process to achieve consistent penetration. Huang (1983) reported that brine injection with and without EDTA and sodium ascorbate produced uniform sodium chloride distribution in mackerel fillets. However, injection followed by dipping in sodium chloride solution was needed in mullet fillets. Injection reduced the time required for producing uniform and effective sodium chloride concentration compared to conventional brining procedures. Consumers detected no significant difference in desirability of smoked fish injected with brine and those soaked in sodium chloride solution. 


\section{Effect of salt on smoked fish characteristics}

To fulfill Food and Drug Administration requirements, a high brine concentration or a long brining time is used in conventional brining approaches. However, products that are too salty are unacceptable to most consumers. Nketsia-Tabiri and Sefa-Dedeh (1995) reported that final moisture, salt content, and sensory quality (texture and overall acceptability) of salted, dried tilapia, Oreochromis niloticus, were dependent on salting time, drying time, and drying temperature. Salt content of products was largely determined by salting time. Highly acceptable products were obtained from tilapia samples salted for relatively short times.

Sodium chloride increases water binding and swelling of meat. The nature of the binding between salt ions and protein is mainly an electrostatic interaction due to the attraction of salt ions by positively or negatively charged groups on the protein. In addition, Van der Waals forces may be effective, particularly with anions of higher molecular weight (Hamm, 1960). Salt effect on water binding properties of protein can be explained by specific ion binding, or the influence of ionic strength. In the acidic $\mathrm{pH}$ range, electrostatic repulsion between positively charged groups of protein is reduced by anion binding. The result of this reaction is a tightening of protein structure and a decrease in water holding capacity. The stronger the ion is bound, or, in other words, the more that positive charges are "screened" by anions, the greater will be protein dehydration. 


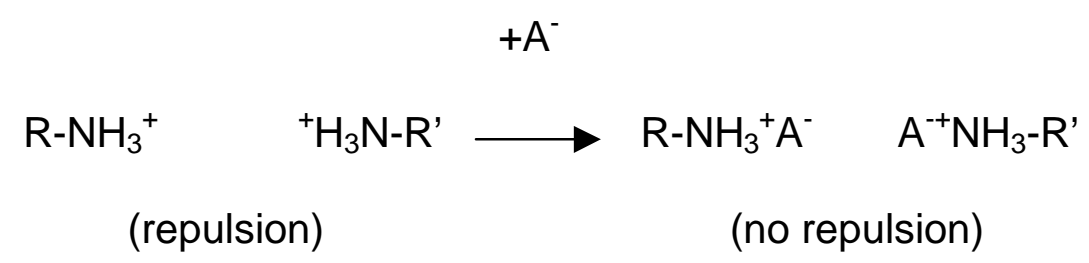

In the basic $\mathrm{pH}$ range, more negatively charged groups are present on the protein that form salt bridges with positive charges. Therefore, anion binding has an opposite effect in the basic $\mathrm{pH}$ range. Widening of the muscle structure occurs, and consequently, water holding capacity and swelling increases. The more tightly the anion is bound, the stronger will be the hydrating effect of the anion.

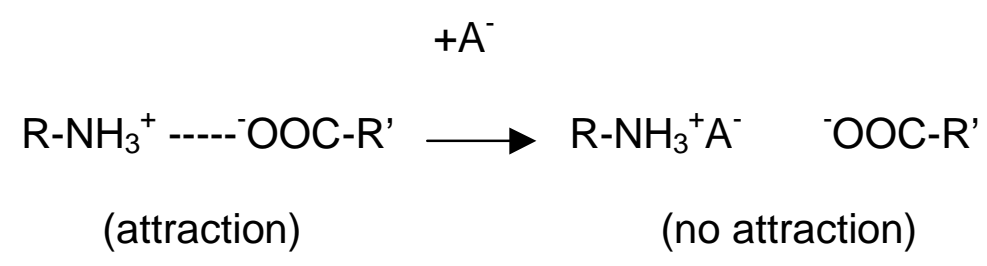

Enhances water binding by sodium chloride is due mainly to the chloride ion. First of all, the isoelectric point of muscle is artificially shifted to a lower $\mathrm{pH}$. Above the isoelectric point, chloride ions increase the net negative charge on the polypeptides that enhances repulsion between polypeptides, and thereby, facilitates imbibition of water by the protein network.

At a low ionic strength $(0.3-1.0 \mathrm{M} \mathrm{NaCl})$, salts increase water binding capacity of proteins. This effect occurs because hydrated salt ions bind weakly to charged groups on proteins. Therefore at low salt concentrations, increased water binding results from water associated with bound ions. However, at a high 
salt concentration, much of the existing water is strongly bound to salt ions. There are not enough water molecules available for protein solvation. Therefore, protein-protein interactions become more powerful than protein-water interactions and lead to aggregation followed by precipitation of protein molecules. This results in dehydration of the protein (Fennema, 1996).

Salt affects product appearance. Salting causes a slight decrease in the breaking strength of connective tissues in hot-smoked fish. This may be due to the fact that salt decreases the rate of moisture loss. Thus, gelatinization of collagen may occur before the connective tissues become dried and impregnated with smoke components. This effect resulted in gaping and tearing of smoked fish (Doe et al., 1982).

$\underline{\text { Salt and health concern }}$

Although debate continues among scientists regarding association between salt intake and risk of developing high blood pressure, the 1995 Dietary Guidelines support the concerns by recommending a diet moderate in salt and sodium. Astawan and coworkers (1994) studied the effect of high salt content of Indonesian dried salted skipjack tuna, Katsuwonus pelamis, on rats. Fish were immersed in $25 \%(\mathrm{w} / \mathrm{v})$ sodium chloride for $24 \mathrm{~h}$ at ambient temperature $\left(28^{\circ} \mathrm{C}\right)$ at a fish to brine ratio of 1:2 (w/v). After salting, fish were dried in a drier for $40 \mathrm{~h}$ at $45^{\circ} \mathrm{C}$. In the final product, moisture and sodium chloride content, and water activity were $33 \%, 23 \%$, and 0.74 , respectively. Dried, salted fish's high salt content significantly increased higher blood pressure, hypertrophy of most 
internal organs, and increased loss of several minerals through urinary excretion in rat.

\section{Ante-mortem factors affecting fish protein characteristics}

Exposure of fish to stress induces responses that are usually considered in terms of primary, secondary and tertiary changes. These changes involve successively higher levels of biological organization starting at the level of the endocrine system and concluding with changes displayed at the whole-animal level.

\section{Primary stress responses - The endocrine system}

The primary stress response process starts when external or internal sense organs detect adverse stimuli that, in turn, relay information to the hypothalamus. Afferent neural pathways run in the nervous system from the hypothalamus to the chromaffin tissue of the head kidney (anterior portion of kidney), and direct stimulation of this tissue causes release of catheolamines (adrenaline and/or noradrenaline). Liberation of catecholamines into the bloodstream initiates a series of secondary responses in other organ systems. Another mechanism of primary stress response results in an increase in corticosteroids from interrenal tissue which is governed by the hypothalamicpituitary-interrenal axis. Following stimulation, the hypothalamus produces corticotropin releasing factors (CRFs). The CRFs stimulate release of adrenocorticotropic hormone $(\mathrm{ACTH})$ from the pituitary gland into the bloodstream. This signal travels to the interrenal cells of the head kidney, where it stimulates production and release of corticosteroid hormones. In most of the 
teleost fish species, cortisol is the major corticorsteroids (Pickering, 1981; Jobling, 1994).

The exposure of salmonid fish to an acute stress, such as handling stress, may lead to a rapid increase of plasma cortisol. This elevation may persist for several hours provided exposure to the stressor has been of short duration. Usually, plasma cortisol concentration will have returned to baseline within $24 \mathrm{~h}$. Study of the effects of thermal stress in sockeye salmon, Oncorhynchus nerka, showed that adrenaline increased during the first $10 \mathrm{~min}$, and then remained steady regardless of stress duration up to $3 \mathrm{~h}$ (Mazeaud et al., 1977). Jobling (1994) reported that when fish are subjected to the stressor, either repeated or chronically, plasma cortisol may remain elevated for several days or even weeks before returning to the baseline value.

Secondary stress responses - Tissue alterations

Release of catecholamines and cortisol triggers a broad suite of biochemical and physiological changes known collectively as the secondary stress responses. Metabolic effects may include hyperglycemia, hyperlacticemia, depletion of tissue glycogen reserves, lipolysis, and inhibition of protein synthesis. There may also be an increase in catabolism of muscle protein and alterations in plasma levels of amino acids, free fatty acids, and cholesterol. Catecholamines cause initial elevation of plasma glucose by mobilizing liver glycogen reserves. Osmotic and ionic disturbances may occur as the result of diuresis and the loss of electrolytes from the blood. A reduction in white blood cells has been reported. Catcholamines have marked influences on 
the cardiovascular system, leading to changes in patterns of blood flow, increased gill perfusion, and alterations in oxygen transport capacity of the blood; whereas, corticosteroids stimulate ion-transporting mechanisms present in the gills and kidney (Pickering, 1981; Jobling, 1994).

Tertiary stress responses - Long-term effects

Exposure of fish to many types of stressors may result in an increased susceptibility to a wide range of common pathogens, a reduction of reproductive success, a depression of growth rates, and decreased disease resistance (Jobling, 1994).

Environmental stressors

Temperature acclimation: Tropical fish and temperate fish myosin have different thermal stabilities, apparently related to their habitat temperatures. These differences in stability affect processing and storage technologies. Comparative studies on tropical and temperate fish confirmed the relationship between myosin thermal stability and habitat temperature for whole muscle and isolated proteins (Davies, 1989; Dogra, 1991).

Johnson and coworkers (1975) compared myofibrillar properties from white muscles of Antarctic fish, Notothenia rossii, and tropical species, Amphiprion sebea. Myofibrillar ATPase from Antarctic fish had a much higher specific activity at low temperatures than did that from the tropical fish. This may be explained in terms of increased weak bond formation in myosin of Antarctic fish. The more compact and rigid myosin structure of tropical fish seems to be necessary for molecular thermal stability at higher environmental temperatures. 
By using differential scanning calorimetry, Nakaya and coworkers (1995) showed that transition temperatures of myosin and rod region prepared from carp, Cyprinus carpio, acclimated to $10^{\circ} \mathrm{C}$ were lower than those prepared from carp acclimated to $30^{\circ} \mathrm{C}$. Structural changes in the myosin molecule induced by lowtemperature acclimation caused acto-S1- $\mathrm{Mg}^{2+}$-dependent ATPase activity to increase at low temperature (Watabe et al., 1992). Furthermore, temperature acclimation caused changes in the rod region of the myosin molecule because the molecular size of light meromyosin from cold-acclimated fish was less than that from warm-acclimated fish (Watabe et al., 1992).

Strange and coworkers (1977) reported that in two groups of cutthroat trout, Salmo clarki clarki, acclimated to the water temperatures of 9 and $23^{\circ} \mathrm{C}$, corticosteroid concentration responded in the same pattern upon continued severe confinement until $40 \mathrm{~min}$. At this time, fish at $23^{\circ} \mathrm{C}$ water failed to maintain an increased corticosteroid concentration in response to continued handling to 70 min compared to fish in cool water. Handling might be expected to generate a greater and continued increase than would temperature. A possible moderating effect of heat on the rise in corticoid concentration was indicated.

Handling stress: After death, fish pass through several stages including rigor mortis, resolution of rigor mortis (autolysis) and bacterial spoilage. Types and rates of quality deterioration vary depending on the physiological state of fish before death and environmental factors after death. Moreover, this variation is species-specific. Capture, handling, and transportation are traumatic procedures 
that may cause considerable physiological reactions in fish. These activities cause the release of adrenaline and cortisol, and are followed by secondary changes such as increased muscle activity and mobilization of energy stores in muscle and liver. Stress and muscle activity during netting and stunning of fish shorten the time for rigor onset. The progression of rigor mortis is used as an index of flesh quality (Lowe et al., 1993). Stressed fish develop stronger rigor mortis that, in turn, affects texture (Sigholt et al., 1997). Therefore, good quality fish can be produced if good handling practices are followed before processing.

Mazeaud and coworkers (1977) studied primary and secondary effects of stress in three salmon species: coho, Oncorhynchus kisutch; sockeye, O. nerka; and Chinook, O. tshawytscha. All types of stress resulted in an increase in plasma catecholamine and corticosteroid concentrations. Adrenaline was predominant; noradrenaline was present at a lower concentration but showed the same relative response to stress. These results for Oncorhynchus species resembled the Salmo species but differed from other teleosts such as the carp. Struggling and hypoxia in coho salmon did not affect adrenaline levels between sexes in either unstressed or stressed groups. However, some data points indicated that females respond to stress faster than males. Therefore, during spawning females were more responsive to stress than males. For secondary effects, hormones disturbed metabolism and osmoregulation in fish. Decreased plasma free fatty acid induced by stress in carp and the opposite pattern in trout are endocrinological issue that have not been clarified yet. Some strains of domesticated rainbow trout responded poorly to catecholamines with respect to 
glucose and lipid metabolism that may be linked to insensitivity to stress. It is well known that many fish turn pale during application of stress. Carp and trout turned pale after approximately 10 min and recovered to a normal color within an hour after removal of the stress. This short-term effect of melanocytes was nearly coincident with the presence of catecholamines in plasma (Mazeaud and Mazeaud, 1981). Crowding mackerel, Scomber scombrus L., caused a change in the overall body color from green to blue. Blue fish were found to have higher blood lactate, cortisol, and sodium ion concentrations. However, these changes did not significantly correlate to body color. The mechanism of color change is unknown (Lockwood et al., 1981).

Alterations in circulating concentrations of adrenaline are probably responsible for the effect of handling stress on water balance. Stress causes a weight loss in seawater fish and a weight gain in fresh water species. This response is explained by the action of adrenaline on gill function that results in increased permeability to water. Stress also affects sodium balance, and a loss of sodium across the gill has been reported in rainbow trout following exercise (Randall et al., 1972). Adrenaline increases sodium uptake in the gill of freshwater-adapted rainbow trout (Richards and Fromm, 1970). Pic and coworkers (1975) indicated that adrenaline blocked sodium and chloride excretion across the gill of seawater-adapted mullet. Exercise or handling in fresh water resulted in hemoconcentration concurrent with a higher water content in other tissues and body weight gain in rainbow trout (Stevens, 1968) and in brook trout, Salvelinus fontinalis (Houston et al., 1971). However, it should be 
kept in mind that, beyond osmotic pressure, there are some specific ionic requirements. For instance, excretion of sodium through the gill is linked to potassium in the external environment (potassium affect) (Maetz, 1969).

The effect of handling are clear; lower creatine phosphate (PCr) and adenosine triphosphate (ATP) and higher inosine monophosphate (IMP) were observed in stressed fish when vigorous muscle activity was induced for $10 \mathrm{~min}$ before bleeding. The lower $\mathrm{pH}$ has generally been attributed to hydrogen ion generation associated with ATP breakdown and lactate production (Hochachka and Mommsen, 1983; Wood and Perry, 1985). Glycogen content at death is a primary determinant of ultimate $\mathrm{pH}$ of meat (Ang and Haard, 1985; Black and Love, 1988).

Lowe and coworkers (1993) studied effect of four capture and handling methods on flesh quality of snapper, Pagrus auratus. Plasma cortisol levels were lowest in resting laboratory acclimated fish and were similar to levels found in commercial, 12-h longline fish. Exercised laboratory fish had a high level of cortisol as did fish from the 2-h longline set. Muscle lactate concentrations negatively correlated with decreased ATP levels. Unstressed fish remained in the lag phase before the onset of rigor mortis for the longest period, followed by the exercised fish, the 12-h longline fish, and the 2-h longline fish. Commercial fishing practices minimizing physiological stress response and utilization of endogenous energy reserves in muscle would provide better flesh quality. Lowe and coworkers (1993) recommended holding fish in tanks as one option to facilitate recovery from stress. 
Ferguson and coworkers (1993) demonstrated that body size influenced white muscle acid-base and metabolic status of rainbow trout before and after exercise. The epaxial white muscle was taken, immediately freeze-clamped in pre-cooled tongs, and stored in liquid nitrogen. The time between removing fish from water and freeze-clamping the tissue was less than $10 \mathrm{~s}$. Following $5 \mathrm{~min}$ of exhaustive exercise, muscle lactate concentration was approximately doubled in larger fish compared to smaller fish. The change in mean intracellular muscle $\mathrm{pH}$ of larger fish was greater than the change in the smallest fish. Associated with this increased lactate was a nearly parallel increased metabolic protons produced by larger fish. They stated that larger fish did not posses a greater non-bicarbonate buffering capacity or soluble protein concentration. ATP and glycogen concentrations remained size-dependent and increased with increasing fish length. The level of PCr was size-independent following exercise. Resting intracellular muscle $\mathrm{pH}$ was size- independent, and $\mathrm{pH}$ was 7.3. White muscle $\mathrm{pH}$ of anesthetized Atlantic salmon, Salmo salar, was held at $7.4 \pm 0.1$. Vigorous muscle activity for up to $30 \mathrm{~s}$ during netting resulted in a $\mathrm{pH}$ reduction to $7.2 \pm 0.1$; whereas $\mathrm{pH}$ fell to $6.8 \pm 0.1$ as a result of ante-mortem anaerobic metabolism when fish were stressed for $1 \mathrm{~h}$ (Erikson et al., 1997). Rainbow trout exercised to exhaustion for $10 \mathrm{~min}$ had muscle $\mathrm{pH}$ that initially dropped and then stabilized at 6.7 to 6.8 when fish were subjected to persistent handling stress (Tang and Boutilier, 1991). Jerrett and coworkers (1996) compared properties of rested (anaesthesia) and exhausted (electrical stimulation) Chinook salmon white muscle. Sharply decreased muscle $\mathrm{pH}$ and increased lactate occurred within 2-h 
post-mortem when stored at $2^{\circ} \mathrm{C}$ and remained stable throughout the storage period. Mean muscle $\mathrm{pH}$ and lactate values for the rested fish gradually decreased with storage time. No difference in $\mathrm{pH}$ and lactate was observed between these two treatments after $40 \mathrm{~h}$.

The negative effect of handling stress on fish flesh quality is similar to the well-known effects on avian and mammalian meat. However post-mortem "tenderization" or autolysis of fish muscle is highly undesirable for processors and consumers (Tsuchiya et al, 1992). Saito and coworkers (1959) first introduced $\mathrm{K}$-value as a freshness indicator. The $\mathrm{K}$-value is calculated as $\mathrm{K}=$ $\{(\mathrm{Hx}+\mathrm{H} x \mathrm{R}) /(\mathrm{Hx}+\mathrm{H} x \mathrm{R}+\mathrm{IMP}+\mathrm{AMP}+\mathrm{ADP}+\mathrm{ATP})\} \times 100 \%$ where $\mathrm{Hx}, \mathrm{HxR}, \mathrm{IMP}$, AMP, ADP, and ATP are the concentrations of hypoxanthine, inosine, inosine monophosphate, adeosine monophosphate, adenosine diphosphate, and adenosine triphosphate, respectively (Erikson et al., 1997). The K-value of very fresh fish suitable for raw consumption should be $<20 \%$ (Hoshi et al., 1991). Handling stress during harvest resulted in higher K-values than in anesthetized sturgeon, Acipenser transmontanus (Izquierdo-Pulido et al., 1992), in rapidly removed of snapper from the holding tank followed by immediate killing (Lowe et al., 1993), and in instantly killed horse mackerel, Trachrus japonicus (Mochizuki and Sato, 1994). It seems that rapid stunning/immobilization of the salmon with minimum muscle activity before bleeding provided the best quality (Erikson et al., 1997). Berg and coworkers (1997) reported that unstressed (anesthetized) salmon contained very little IMP (less than $1 \mu \mathrm{mol} / \mathrm{g}$ dry wt). Rapid netting of individual fish followed by a blow to the head resulted in minor IMP-formation, a 
decrease in ATP, and a large drop in $\mathrm{PCr}$ content. This difference in the distributions of PCr, ATP, and IMP for commercial fish from harvest to ice storage indicated that effects of handling stress were substantial. During subsequent storage, ante-mortem struggle reduced flesh quality as reflected by a higher K-value (Izquiredo-Pulido et al., 1992; Lowe et al., 1993).

Erikson and coworkers (1997) studied three different ante-mortem handling stress scenarios in Atlantic salmon anesthetized (baseline), quickly netted and killed by a blow to the head (unstressed), and chased to exhaustion in the holding tank (stressed). K-value of anesthetized fish muscle did not start to increase until 1-d post-mortem because ATP was retained in the muscle. Rigor onset started about 25-h post-mortem. Fish were still in rigor at $72 \mathrm{~h}$, although not as strong as 48-h post-mortem. Stressed fish developed a strong rigor after 2 to $4 \mathrm{~h}$, which resolved at about 24-h post-mortem. Rigor onset of the unstressed group started between 6-and 24-h post-mortem and it had resolved by 48 -h post-mortem. They indicated an upper K-value of 70 to $80 \%$ for good quality Atlantic salmon and lower than 40 to $50 \%$ for excellent quality. The primary benefits of reducing handling stress were to reduce degree of rigor contraction and to improve texture properties of the muscle. They noted that stressed fish developed a much stronger rigor and a softer muscle texture that was more susceptible to gaping than unstressed fish. Sigholt and coworkers (1997) hypothesized that a strong rigor mortis and rapid decline in post-mortem $\mathrm{pH}$ may increase the degree of protein denaturation, increase the access of substances to proteolytic enzymes, and cause more rapid softening of flesh. 
Higher muscle tensions have been reported in stressed blue tilapia, Oreochromis aureus (Korhonen et al., 1990), and stressed carp (Nakayama et al., 1994). This tension, in turn, made the collagen fibers in stressed fish more susceptible to disintegration resulting in tenderization of the muscle (Ando et. al., 1992). Jerrett and Holland (1998) reported that rigor contraction of Chinook salmon white muscle started when muscle $\mathrm{pH}$ dropped to 6.6 and ended when muscle $\mathrm{pH}$ plateaued at 6.2 to 6.3. Ante-mortem handling stress provided a possible explanation of the apparent increase in rigor contraction intensity with increasing muscle fatigue.

Crawford and coworkers (1970) showed that exercised skipjack tuna went into deep rigor within $30 \mathrm{~min}$; whereas, rested fish showed only weak signs of rigor from the time of sacrifice to canning. Free glucose, glucose phosphate, fructose phosphate and total reducing sugars were lower in exercised than in rested fish after killing and holding in 23 and $0^{\circ} \mathrm{C}\left(74\right.$ and $\left.32^{\circ} \mathrm{F}\right)$ seawater for $6 \mathrm{~h}$ before canning. At both temperatures, lactate was higher in the exercised and rested fish compared to their controls, which were exercised or rested fish that were sacrificed and immediately canned. Frozen storage had a greater effect on canned tuna color than did stress; Little (1972) hypothesized that post-mortem denaturation of myoglobin inhibited conversion to hemochrome, the pigment responsible for the typical color of canned tuna.

Effects of handling stress on muscle protein functionality have been studied. Water-holding capacity is an important protein functionality in processed muscle foods and it influences the texture of fish; it is largely dependent on 
muscle pH. Gomez-Guillen and coworkers (2000) showed that there was slight loss of protein solubility at high ionic strength $(0.85 \mathrm{M} \mathrm{NaCl})$ due to stress in farmed Atlantic salmon. Water-holding capacity was not affected by stress. Shear strength of the myofibrillar fraction was not affected by stress as determined by Warner-Bratzler shear. Shear strength of connective tissue was lower in stressed than in non-stressed fish, indicating susceptibility of collagen fibers to disintegration in stressed fish. However, disintegration of collagen fibers is not in agreement with solubility data. Shear strength of the whole muscle, determined by Kramer shear, was lower in stressed than in non-stressed fish. According to Sigholt and coworkers (1997) and Erikson and coworkers (1997), decreased protein solubility (in $0.85 \mathrm{M} \mathrm{NaCl}$ ) is associated with protein denaturation resulting from rapid onset of rigor mortis in stressed fish. Muscle softening in stressed fish as determined by Kramer shear was due less to weakening of the myotomes than to weakening of the myocomata. They concluded that muscle softening in stressed fish was associated with myofibrillar protein denaturation. Thirty-day starvation increased collagen insolubility leading to muscle hardening. There were no large differences in proximate composition of raw fish having different stress treatments.

\section{Freezing and subsequent frozen storage}

Frozen storage is the one of the most important methods for maintaining chemical and microbiological stability and thereby, extending shelf life of food products. Freezing and subsequent storage at subfreezing temperatures preserve taste, texture, and nutritional value better than any other method. As a 
result, large quantities of food are frozen worldwide including fish and fish products. However, freeze-induced protein denaturation, lipid oxidation, and associated functionality losses are commonly observed in frozen fish. Highquality frozen fish depends upon fish condition before freezing, and on freezing, storage, and thawing parameters.

Fish condition: The strictest attention to fish handling is required to minimize adverse effects induced by various biological characteristics. Shelf life of lean fish is limited by severe protein alterations that cause protein aggregation resulting in firm fillets with low water-holding capacity. The quality of fatty species suffers from oxidative changes to lipids and pigments that are reflected in rancid odor and discolorations of the flesh (Hultin, 1992). Hsu and coworkers (1993) indicated that large variation in their data was due to the quality factors present prior to freezing. These pre-freezing quality characteristics may also affect quality changes during freezing and subsequent storage. Nilsson and Ekstrand (1995a) suggested that fast freezing after rigor mortis was considered optimal for fish. Montecchia and coworkers (1997) showed that fillets from prespawned hake, Merluccius hubbsi, stored at $-20^{\circ} \mathrm{C}$ deteriorated faster than those from post-spawned hake. Protein solubility of 85.5 and $33 \%$ of the total proteins was obtained at the end of $240 \mathrm{~d}$ of storage for post and pre-spawned fillets, respectively.

Freezing rate: Freezing is a physical process involving transformation of water molecules from an amorphous state to ice crystals. Sources of damage are thought to be associated with ice formation through intracellular to 
extracellular migration of water. Freezing rate is an important parameter. During slow freezing, centers of crystallization are first formed in the intercellular spaces. Freezing this water increases the concentration of dissolved solid in the unfrozen aqueous phase and this, in turn, increases the osmotic pressure of liquid in the intercellular spaces. In order to equalize the concentration of solids in the liquid from inside to outside cells, water diffuses from the cells into the intercellular spaces. This migration causes growth of ice crystals and shrinkage of myofibrils. Freezing rate should be fast enough to prevent formation of large ice crystals in the intercellular spaces. In quick freezing, heat removal is sufficient to initiate formation of ice crystals both inside and outside cells. Therefore, osmosis of water from cells does not occur. However, rapid freezing causes significant myofibril damage, looseness of myofibrils, and larger spaces between them than in fresh muscles (Grujic et al., 1993). Results indicated that beef, $M$. longgissimus dorsi, was best frozen at temperatures above the eutectic point (-40 to $-50^{\circ} \mathrm{C}$ ) with freezing rates between $3.33 \mathrm{~cm} / \mathrm{h}$ and $3.95 \mathrm{~cm} / \mathrm{h}$. Muscles frozen under such conditions had the least damage.

Frozen storage condition: Hastings and coworkers (1985) reported that freezing followed by immediate thawing, without frozen storage, had little effect on thermal transitions of cod muscle. However, myosin had undergone some partial denaturation after 2-wk storage at $-10^{\circ} \mathrm{C}$, while frozen storage did not largely affect actin, collagen, and sarcoplasmic proteins. Park and Lanier (1987) reported that amount and composition of protein aggregates increased with prolonged frozen storage of Jumping mullet myofibrils. Biochemical reactions 
that lead to meat deterioration do not stop after prolonged storage even at $-20^{\circ} \mathrm{C}$. These reactions are slowed down; however, they still continue because a part of water in the meat remains liquid at these temperatures. Thus, undesirable changes in product texture and odor occur (Grujic et al., 1993). According to Anderson and Steinsholt (1992), frozen storage at decreasing temperatures between -13 and $-35^{\circ} \mathrm{C}$ significantly increased color retention in salmon. Hsu and coworkers (1993) found that changes in salt-soluble protein extractability, $\mathrm{Ca}^{2+}$-stimulated ATPase acitivity, and shear strain of Pacific whiting, Merluccius productus, fillets stored at $-8^{\circ} \mathrm{C}$ were significantly greater than those stored at lower temperatures. Fillets stored at -34 and $-50^{\circ} \mathrm{C}$ had no significant advantage over those stored at $-20^{\circ} \mathrm{C}$ as measured by salt-soluble protein extractability and $\mathrm{Ca}^{2+}$-stimulated ATPase acitivity.

Thawing method: Nilsson and Ekstrand (1995b) investigated the effect of thawing methods on biochemical attributes of farmed rainbow trout. Slow thawing, in air at $5^{\circ} \mathrm{C}$, resulted in higher membrane disintegration and a larger volume of centrifuged tissue fluid compared to fast thawing in air or in water at $25^{\circ} \mathrm{C}$, regardless of frozen storage time. Lower storage temperature at $-40^{\circ} \mathrm{C}$ did not affect membrane structures after different thawing treatments as much as higher storage temperature at $-18^{\circ} \mathrm{C}$ did. These results together with sensory evaluation of juiciness and firmness indicated that lower storage temperature in combination with fast thawing contributed to the better final fish quality. Using electrophoretic analysis, gradual decreases in myosin, actin, and most other 
myofibrillar proteins occurred in each freeze-thaw cycle of prawns, Machrobrachium rosenbergii (Srinivasan et al., 1997).

Freeze-induced protein denaturation

Proteins are stabilized by the combination of hydrogen and disulfide bonds and electrostatic and hydrophobic interactions. Hydrophobic interactions provide important stability to the three-dimensional native structure of proteins by keeping it folded (Back et al., 1979). Protein denaturation involves alterations of secondary and tertiary structures due to breakage of hydrogen bonds, disulfide bonds, electrostatic interactions and hydrophobic interactions without rupture of the covalent peptide linkages. Denaturation factors bring about a partial or total deconformation of the native molecules. In frozen fish, freeze-induced protein denaturation is usually manifested as aggregation, precipitation, or polymerization of proteins. Aggregation-denaturation of fish muscle proteins primarily involves myosin, actin, tropomyosin, and troponin. Aggregation is considered to be caused by hydrophobic, hydrophilic and ionic interactions and the formation of covalent bonds among protein molecules, lipids, free fatty acids, free amino acids, formaldehyde, and other constituents (Jiang et al., 1986). Disulfide linkages and hydrophobic interactions have been reported in the formation of fish myosin aggregates (Chan et al., 1995).

Three accepted theories explaining freeze-induced protein denaturation are: 1) an increase in solute concentration, 2) cellular dehydration, and 3) autoxidative reactions. 
$\underline{\text { Increased solute concentration }}$

Muscle proteins have been grouped into one of three categories based on their solubility. The sarcoplasmic proteins, or myogen, are soluble in water or dilute salt solutions. Most of these water-soluble proteins are enzymes, such as those involved in glycolysis, and the muscle pigment myoglobin. The salt-soluble proteins have been equated with the myofibrillar proteins and are defined as those soluble in relative high concentration of salt $(0.3-1.0 \mathrm{M} \mathrm{NaCl})$. Defining the salt-soluble proteins as myofibrillar is possibly a reflection of the dominating importance of myosin in establishing the physical properties of muscle proteins. Myosin has been reported generally not to be soluble in salt solutions of ionic strength less than 0.3. This insolubility of myosin at low ionic strength is a consequence of the interactions of myosin rod regions. The insoluble fraction that remains after treatment with salt solutions is stromal proteins, and they consist of connective tissue proteins, membrane proteins, and usually some unextracted myofibrillar proteins (Hultin et al., 1995; Foegeding et al., 1996).

As freezing progresses, mineral salts concentrate in the remaining nonfrozen aqueous phase inside cells. The increase in solute concentration, with corresponding changes in ionic strength and $\mathrm{pH}$, is believed to affect protein native structure by increasing dissociation and/or denaturation. Proteins generally show an increase in solubility (salting-in) with low ionic strength (0.3$1.0 \mathrm{M} \mathrm{NaCl}$ ). At high ionic strength, competition of ionic salts for water may result in a salting-out effect. Water interacting with protein is decreased, in turn, causing decreased solubility. Salting-in has been ascribed to nonspecific 
electrostatic interactions between charged proteins and the ionic environment. Salts that increase solubility of proteins also tend to denature them. Salts are either preferentially bound to proteins or react with them slightly. Sodium chloride, at concentrations from 0.3 to $1.0 \mathrm{M}$, induces a salting-in effect of myofibrillar proteins and should make these proteins less stable. Salting-out is strongly dependent on the salt that is used. In general, the salting-out effect of the anions and cations follow the lyotropic or chaotropic series (Damodaran and Kinsella, 1982):

$$
\begin{aligned}
& \mathrm{SO}_{4}{ }^{2-}>\mathrm{Cl}^{-}>\mathrm{Br}^{-}>\mathrm{NO}_{3}^{-}>\mathrm{ClO}_{4}^{-}>\mathrm{SCN}^{-}>\mathrm{Cl}_{3} \mathrm{CCOO}^{-} \\
& \mathrm{NH}_{4}^{+}>\mathrm{K}^{+}, \mathrm{Na}^{+}>\mathrm{Li}^{+}>\mathrm{Mg}^{2+}>\mathrm{Ca}^{2+}>\mathrm{Ba}^{2+}
\end{aligned}
$$

Salting out is generally ascribed to the loss of a stable hydrophilic surface, causing the exposed hydrophobic areas of proteins to interact, and proteins subsequently aggregate and precipitate. Park and coworkers (1987) reported that sodium chloride accelerated destabilization of muscle proteins in comminuted beef muscle when added prior to freezing. Lin and Park (1998) demonstrated that myosin regained its helix structure with a concomitant loss of solubility due to the dominant hydrophobic interaction among nonpolar amino acid residues at potassium chloride concentration greater than $1 \mathrm{M}$. Arakawa and Timasheff (1984) used the preferential interactions of proteins with the solvent components in a three-component system such as protein-water-salt to explain the manner by which additives affect the solubility and stability of proteins. Those additives that show stabilizing or salting-out effects on macromolecules are characterized by a large preferential hydration of proteins. 
Salting-out and stabilizing or salting-in and destabilizing effectiveness of divalent cation salts, interpreted in terms of the observed preferential interactions of proteins, were in agreement with the cationic lyotropic series. The electrostatic interactions between divalent cations and proteins overcame protein hydrophobic interactions leading to a decrease in the preferential hydration. Magnesium chloride effects were strongly $\mathrm{pH}$ dependent because of protein chargedependent affinity of magnesium ions for proteins, while sodium chloride showed no $\mathrm{pH}$ dependence of the preferential interaction. Fukumi and coworkers (1965) found that freeze-induced denaturation of washed actomyosin from Alaskan Pollock was accelerated by calcium, magnesium, potassium, and sodium ions and reduced by their removal.

\section{Cellular dehydration effect}

In a dehydrated state, protein-water interactions in tissue are disrupted and protein molecules are exposed to an organic environment that is less polar than water. This process results in increased exposure of hydrophobic residues and therefore, changes protein conformation. Gill and coworkers (1992) indicated that exposure of highly non-polar residues (surface hydrophobicity) led to enhanced aggregation of cod, Gadus morhua, myosin when studied in the temperature range between 35 and $55^{\circ} \mathrm{C}$.

\section{$\underline{\text { Autoxidation effects }}$}

Autoxidative reactions such as lipid oxidation cause protein denaturation and deterioration of muscle protein functional attributes by causing cross-linking between protein and lipid oxidation products. Dyer and Dingle (1961) observed 
free fatty acid formation preceded loss of myofibrillar protein extractability during frozen storage and that the latter was more rapid in lean species than in those containing more fat. Miller and coworkers (1980) reported that frozen storage significantly affected thiobarbituric acid (TBA) values of beef fat and peroxide values in pork fat. Malonaldehyde production in beef relative to time of frozen storage occurred at a higher rate than malonaldehyde production in pork. This phenomenon is contrary to expected results since pork contains a higher percentage of unsaturated lipids. This increase is perhaps explained by higher iron-containing pigments in beef muscle; these heme pigments can act as prooxidants. Wang and coworkers (1997) found that lipid and protein oxidation in washed beef heart surimi increased rapidly after 4-wk frozen storage. Both oxidative reactions were minimized at $-70^{\circ} \mathrm{C}$ storage compared to storage at -15 and $-29^{\circ} \mathrm{C}$. Srinivasan and coworkers (1997) showed that shear force of cooked prawns decreased after three freeze-thaw cycles that coincided with accelerated lipid oxidation in raw prawns. However, Han and Liston (1989) indicated that lipid oxidation in salmon and rainbow trout was minimized during frozen storage due to natural antioxidant (astaxanthin) in muscle. High concentrations of salt (2$3 \%$ ) in processed muscle foods are able to catalyse lipid oxidation in both raw and cooked products (Rhee et al. 1983; Kanner et al., 1991). Cross-linking of protein via disulfide linkages, the result of oxidation, are hastened by addition of 0.6 M sodium chloride. In addition, salt at this concentration is capable of catalyzing protein oxidation in beef heart surimi as indicated by increased protein carbonyls (Srinivasan and Xiong, 1996). 


\section{Changes in muscle protein solubility}

Deterioration of fish proteins during frozen storage is reflected mainly as a drastic decrease in solubility. This phenomenon has been thoroughly investigated in muscle foods and in protein solutions to determine which fractions are susceptible to these changes and to elucidate mechanisms of desolubilization. Awad and coworkers (1968) found that total protein, sarcoplasmic protein and actomyosin extractability decreased with frozen storage. There are published data indicating that decreased protein extractability during frozen storage was due to alterations of myofibrillar proteins. Sarcoplasmic proteins do not undergo significant changes (Dyer and Dingle, 1961; Hurling and McArthur, 1996). According to differential scanning calorimetric profiles of cod muscle, actin and sarcoplasmic proteins are less susceptible to thermal denaturation than are collagen and myosin (Hastings et al., 1985). Protein changes reported by Miller and coworkers (1980) supported the theory that lipid oxidative and degradative products formed and interacted with muscle tissue decreasing protein solubility during frozen storage of meat. Hurling and McArthur (1996) studied frozen storage effects in cod and they found that myofibrillar protein solubility decreased from 70 to $22 \%$ of the total protein after $9-\mathrm{m}$ storage at $-30^{\circ} \mathrm{C}$. They also indicated that decline in protein solubility was not caused by complete protein unfolding. Insolubilization of proteins during frozen storage is caused by formation of intermolecular hydrogen and/or hydrophobic bonds as well as disulfide bonds and ionic interaction (Akahane, 1982). Owasu-Ansah and Hultin (1986) reported that the decrease in protein 
extractability of frozen red hake, Urophycis chuss, fillets could be partially reversed by $\beta$-mercaptoethanol. Sodium dodecyl sulfate (SDS) reduced the loss in extractability. Polypeptides that would not enter $10 \%$ polyacrylamide gels after treatment with SDS and $\beta$-mercaptoethanol were formed during frozen storage. The decrease in myosin heavy chain followed first order kinetics with a rate constant of -0.054 per week at $-7^{\circ} \mathrm{C}$; its decrease closely paralleled the appearance of cross-linked peptides. Zotos and coworkers (1995) indicated that the decrease in salt-soluble proteins seemed to be affected by interactions between lipid oxidation products and free amino acids formed during 33-wk storage of mackerel at $-20^{\circ} \mathrm{C}$. Montecchia and coworkers (1997) observed a slight increase in salt-soluble protein from hake after 15-d frozen storage at $-20^{\circ} \mathrm{C}$ followed by gradual decrease until the end of frozen storage. This slightly increased protein solubility might be caused by modifications of chemical groups, especially sulfhydryls. These changes would cause a transitory modification of molecular conformation as was suggested by in vitro experiments with carp actomyosin, myosin, and heavy meromyosin during short term frozen storage (Matsumoto, 1980).

Nakayama and coworkers (1979) reported that significant intermolecular interaction and aggregation occurred between carp actomyosin molecules and continued for a long time at higher actomyosin concentration. Actomyosin aggregation did not take place at low concentration (4.5 mg protein $/ \mathrm{mL})$. Cod actin does not change significantly during prolonged storage at $-14^{\circ} \mathrm{C}$ (Connell, 
1960). del Mazo and coworkers (1999) showed that hake actin in the extracts remained constant with frozen storage.

Changes in muscle protein functionality

Significant deterioration of frozen fish texture can be observed as increased toughness and firmness. According to Connell (1962), toughness and the loss of water-holding capacity are caused by formation of additional linkages and by greater strength of existing linkages between myofibrillar proteins.

Many researchers have studied the relationship between protein solubility, protein functionality and sensory attributes. Connell and Howgate (1968) found that protein extractability, $\mathrm{pH}$, and sensory firmness were significantly correlated, indicating that protein extractability and $\mathrm{pH}$ could be used to predict cooked fish attributes. Borderias and coworkers (1982) reported that decreased firmness of minced trout during frozen storage might have been due to the loss of cohesion between mince particles, but were not directly connected to decreased protein solubility. In contrast, Clarke and coworkers (1994) concluded that protein extractability, $\mathrm{pH}$, thaw drip, trimethylamine (TMA) and dimethylamine (DMA) contents, thiobarbituric acid reactive substances (TBARS), and instrumental texture were unsuitable for assessing quality of frozen cod. Hurling and McArthur (1996) indicated that changes in cod muscle functionality did not validate direct inference to sensory attributes. They suggested that myofibrillar protein solubility data should be used only as an approximate indicator of sensory properties. 
Fish proteins are more sensitive to changes in ionic strength than mammalian or avian proteins. Water-holding capacity was inversely related to salt content (Bligh and Duclos-Rendell, 1986; Alvarez et al., 1995). This trend may be related to competition between salt and protein for the solvent, causing a smaller number of water molecules to interact with proteins. Park and Lanier (1989) showed that addition of $3 \%$ salt to surimi shifted denaturation transitions

of myofibrillar proteins to lower temperatures and decreased enthalpies of heat denaturation.

\section{Cryoprotectants stabilization of protein}

To minimize deterioration of protein in frozen fish, suitable protection should be used. Some methods are common to all species of fish and processed products. However, a particular species of fish or products should be considered differently because of variation in biological characteristics.

Cryoprotectants are compounds that improve quality and extend shelf life of frozen foods. The term cryoprotectant includes all compounds that help to prevent deleterious changes in food caused by freezing, frozen storage, and the thawing process (MacDonald and Lanier, 1997). In cellular foods, such as intact meat, cryoprotectants should stabilize cellular structure and control water movement to prevent cellular collapse, as well as stabilize proteins. Cryoprotectants also increase thermal stability of proteins in general (Ooizumi et al., 1984). However, their importance to food stability during frozen storage may grow in relative significance because solutes become freeze concentrated and, therefore, more reactive. A wide variety of compounds have been used for 
cryoprotection of labile proteins. These compounds include sugars, polyols, carbohydrate polymers, amino acids, and inorganic salts, such as phosphates. Many sugars and polyols are well known as protein cryoprotectants in fish and meat. Park and coworkers (1987) reported that effective cryoprotectants have low volatility, penetrate membranes, are soluble in water with each molecule having an ability to form hydrogen bonds, and increase dissolution of electrolytes.

Lakshmi and Nandi (1976) demonstrated that sucrose and glucose decreased the solubility of phenylalanine, tyrosine, and tryptophan in aqueous solutions and suggested that this was due to increased hydrophobic interactions. In 1979, Back and coworkers proposed a mechanism whereby sugars and polyols increased thermal stability of proteins. Maximum hydrophobic interactions occur when the three-dimensional hydrogen-bonded structure of water is developed. The effects of sucrose and polyols on hydrophobic interactions and, consequently thermal stability of protein should depend on how they affect the structure of water. These authors showed that hydrophobic interactions between pairs of hydrophobic groups were stronger in sucrose and glycerol solutions than in pure water.

Arakawa and Timasheff (1982) reported that glucose and lactose in aqueous solutions of protein increased preferential hydration of proteins or explained the protein stabilization mechanism of these sugars. MacDonald and Lanier (1997) characterized the cryoprotective effect of sugars as cosolvents that preferentially were excluded from protein domains. Preferential exclusion may 
result from an increase in surface tension of water by the cosolvent; in the presence of sugars, the protein is preferentially hydrated and stabilized. In addition, Wang and Kolbe (1990) demonstrated that the initial freezing point decreased with increasing cryoprotectant concentration. Effect of cryoprotectant on water structure optimizes interaction of protein with water during frozen storage.

In cod mince, glucose exhibited a markedly higher protective effect than sucrose (Sikorski et al., 1976), but sucrose is more available than other sugars and polyols. However, many studies have been conducted with other compounds because of the undesirable sweetness and enzymatic browning associated with sucrose. Moral and coworkers (1986) and Tejada and coworkers (1986) used the combination of $3 \%$ sorbitol and $0.5 \%$ monosodium glutamate as cryoprotectants when studying storage temperature and preparation effect respectively on minced trout. Konno and coworkers (1997) demonstrated that turbidity of carp myofibril suspensions decreased in order of lactitol $=$ lactose $=$ maltitol $>$ sorbitol $>$ glucose during heating. Sorbitol promoted solubilization of myofibrillar proteins and reduced sodium chloride required for solubilization. Presently, an $8 \%$ of sucrose/sorbitol mixture in the ratio of 1 to 1 by weight is commercially used in surimi, a freeze-stabilized, semi-processed fish mince (Lee, 1984). Park and coworkers (1987) reported that freezing-accelerated destabilization of beef muscle proteins was reduced most effectively by sucrose/sorbitol mixture followed by Polydextrose ${ }^{\circledR}$. However according to Park and coworkers (1988), Polydextrose ${ }^{\circledR}$ substitution for sucrose/sorbitol 
compromised cryoprotection in Alaskan Pollock surimi. Maltodextrin adversely affected gel-forming properties; although it preserved salt-soluble protein extractability nearly as well as sucrose/sorbitol or Polydextrose ${ }^{\circledR}$.

Mahon and Schneider (1964) reported that dipping fish fillets in a $12.5 \%$ sodium tripolyphosphate solution prior to freezing reduced thawing drip from 6.6 to $0.3 \%$ without significant $\mathrm{pH}$ changes in the flesh. Trout and Schmidt (1983) summarized the mechanism of phosphate action in increasing water-holding capacity of meat products as increasing $\mathrm{pH}$, increasing ionic strength, dissociating actomyosin to actin and myosin, and chelating divalent metal ions. Park and Lanier (1987) investigated the stabilization of Jumping mullet myofibril suspensions against freeze- and heat-induced denaturation by 0.25 or $0.5 \%$ phosphates (sodium tripolyphosphate or neutralized pyrophosphate), alone or in combination with $8 \%$ sucrose/sorbitol or Polydextrose ${ }^{\circledR}$. They concluded that effective cryoprotection was achieved by $0.5 \%$ of either phosphate combined with either carbohydrate treatment. Different scanning calorimetric analysis of the isolated myofibril suspension revealed that phosphate induced stabilization of myosin conformation as observed by a higher transition temperature but it did not affect actin. No differences due to phosphate type were observed in any measured parameter. In contrast, Park and coworkers (1988) indicated that cryoprotection by phosphates seemed to depend on the specific phosphate ion used and/or the $\mathrm{pH}$. Commercial surimi contains a 1:1 mixture of sodium tripolyphosphate and tetrasodium pyrophosphate (Park et al., 1988). Park and coworkers (1993) studied cryostabilization by Polydextrose ${ }^{\circledR}$ in combination with 
phosphates (1:1 mixture of sodium tripolyphosphate and tetrasodium pyrophosphate) in beef. Phosphate did not exert or enhance a cryoprotective effect after $5-\mathrm{m}$ storage at $-28^{\circ} \mathrm{C}$. After $5-\mathrm{m}$ frozen storage, addition of phosphates to muscle enhanced extractability of proteins and thereby enhanced gel-forming and water-retention properties. According to Molins and coworkers (1978), polyphosphate converts to orthophosphate during frozen storage and this hydrolysis may change the properties of polyphosphate. Wright and Wilding (1984) investigated the effects of orthophosphate, pyrophosphate, and tripolyphosphate on the thermal denaturation of rabbit myosin using differential scanning calorimeter. Pyrophosphate destabilized myosin compared to orthophosphate and tripolyphosphate, even though the latter was probably hydrolyzed to orthophosphate and diphosphate.

Noguchi and Matsumoto (1975) reported that, in addition to carbohydrate compounds, carboxylic acids also provided cryoprotection. Sodium lactate protected actomyosin at a level equivalent to sodium glutamate. Stabilization of actomyosin by sodium salts of carboxylic acids, including lactate, was almost proportional to the number of carboxyl groups in their structure (Ooizumi et al., 1984). MacDonald and Lanier (1994) demonstrated that sodium lactate stabilized tilapia (Tilapia nilotica x Tilapia aurea) actomyosin against freeze-thaw and heat denaturation in a model system. Extent of stabilization was dependent on lactate concentration. Optimum cryoprotection was achieved with $6 \%(\mathrm{w} / \mathrm{v})$ sodium lactate. For heat stabilization, sodium lactate was two times more effective than sucrose at an optimum concentration of $25 \%$. They also 
suggested that sodium lactate had potential as a cryoprotectant and actomyosin stabilizer. MacDonald and coworkers (1996) confirmed the effectiveness of sodium lactate as a water structure-maker that, in turn, increased surface tension of solutions.

\section{Antioxidants stabilization of proteins}

To prevent lipid and protein oxidation in frozen fish, many strategies have been applied during fish cultivation, processing, and storage. Bjerkeng and Johnsen (1995) fed rainbow trout with astaxanthin and subsequently studied lipid oxidation at various oxygen transmission rates and illuminations during storage at -13 and $-35^{\circ} \mathrm{C}$. Vacuum packaging retarded oxidative rancidity. Astaxanthin may retard lipid oxidation, especially in fillets subjected to illumination or high oxygen transmission rate packaging material. Moral and coworkers (1986) showed that butylated hydroxy anisol (BHA) and butylated hydroxy toluene (BHT) maintained optimum quality levels of rainbow trout mince over 1-y storage at either $-12,-18$, or $-24^{\circ} \mathrm{C}$. Similar results were reported by Tejada and coworkers (1986) for rainbow trout mince produced from frames after filleting. Hansen and coworkers (1990) succeeded in using an ascorbyl palmitate/ $\alpha$ tocopherol/citric acid mixture to reduce red color loss in various semi-processed products of farmed Atlantic salmon stored at $-30^{\circ} \mathrm{C}$. Turner and coworkers (2000a and b) evaluated the effect of natural antioxidant blends (rosemary extract and tocopherol alone, or with citric acid and ascorbic acid) to control oxidative rancidity in whole fish, fillets, and mince of rainbow trout during 12-m storage at $-29^{\circ} \mathrm{C}$. Natural antioxidant blends retarded development of 
conjugated diene hydroperoxides and malonaldehyde in all samples. Based on sensory evaluation by trained panel, treated samples were less oxidized. However, according to consumer sensory panels, treated and control samples remained acceptable and there was no difference in texture. Srinivasan and Xiong (1997) determined the role of water- and lipid-soluble antioxidants in protecting sulfhydryl oxidation in beef heart surimi. Propyl gallate, $\alpha$-tocopherol, ascorbate, or tripolyphosphate was added to water during muscle washing. Loss of sulfhydryls was prevented by propyl gallate, $\alpha$-tocopherol, and tripolyphosphate. Only propyl gallate decreased loss of sulfhydryls in surimi containing 0.6 M sodium chloride. They also indicated that non-disulfide covalent linkages were nearly absent in the presence of propyl gallate, $\alpha$-tocopherol, and tripolyphosphate. Wang and coworkers (1997) conducted a similar study with respect to the effect on beef heart surimi of propyl gallate in combination with sucrose/sorbitol. Lipid and protein oxidation were monitored during storage at $15,-29$, and $-70^{\circ} \mathrm{C}$ for up to $52 \mathrm{wk}$. Propyl gallate inhibited lipid oxidation (TBARS and dienes), minimized oxidative changes of proteins (loss of sulfhydryls and a reduced formation of carbonyls), but was ineffective against protein conformational changes (surface hydrophobicity and myosin-ATPase). Cryoprotectants protected surimi against protein denaturation (surface hydrophobicity), but promoted lipid oxidation (TBARS) in the absence of propyl gallate. Neither sucrose nor sorbitol has a known prooxidation effect. The mechanism responsible for enhanced lipid oxidation is not clear. Cryoprotectants might create certain aqueous microenvironments in frozen beef heart surimi 
where prooxidants, such as free and complex heme iron, may become more concentrated and, in turn, more catalytically reactive. In addition, increased availability of non-frozen water due to enhanced hydration could aid in diffusion of water-soluble prooxidants (iron and heme) to the lipid-water interface, thereby facilitating lipid oxidation. Whether sucrose and sorbitol act as mediators for lipid oxidation requires further investigation. 


\section{REFERENCES}

Akahane,T. 1982. Denaturation of Fish Muscle Proteins. Ph.D. thesis, Sophia Univ. Tokyo, Japan

Alvarez,C., Couso,I., and Tejada,M. 1995. Sardine gels as affected by salt concentration, blending, heat treatment and moisture. J. Food Sci. 60(3): 622626.

Andersen,U.B. and Steinsholt,K. 1992. Deep frozen salmon: Differences in quality after storage at different temperatures following different storage periods. Norw. J. Agric. Sci. 6: 211-215.

Ando,M., Toyohara,H., and Sakaguchi,M. 1992. Postmortem tenderization of rainbow trout muscle caused by the disintegration of collagen fibers in the pericellular connective tissue. Nippon S. Gakkaishi. 58: 567-570.

Ang,J. and Haard,N.F. 1985. Chemical composition and postmortem changes in soft textured muscle from intensely feeding Atlantic cod, Gadus morhua. J. Food Biochem. 9: 49-64.

Anonymous. 1963. Botulism. Morbid. Mortal. Weekly Rep. 12: 337-339.

Arakawa,T. and Timasheff,S.N. 1982. Stabilization of protein structure by sugars. Biochemistry. 21(25): 6536-6544.

Arakawa,T. and Timasheff,S.N. 1984. Mechanism of protein salting in and salting out by divalent cation salts: balance between hydration and salting binding. Biochemistry. 23(25): 5912-5923.

Astawan,M., Wahyuni,M., Yamada,K., Tadokoro,T., and Maekawa,A. 1994. Effect of high salt content of Indonesian dried-salted fish on rats. J. Agric. Food Chem. 42(10): 2265-2269.

Awad,A., Powrie,W.D., and Fennema,O. 1968. Chemical deterioration of frozen bovine muscle at $-4^{\circ} \mathrm{C}$. J. Food Sci. 33(3): 227-235.

Back,J.F., Oakenfull,D., and Smith,M.B. 1979. Increased thermal stability of proteins in the presence of sugars and polyols. Biochemistry. 18(23): 5191-5196.

Berg,T., Erikson,U., and Nordtvedt,T.S. 1997. Rigor mortis assessment of Atlantic salmon (Salmo salar). J. Food Sci. 62(3): 439-446.

Bjerkeng,B. and Johnsen,G. 1995. Frozen storage quality of Rainbow trout (Oncorhynchus mykiss) as affected by oxygen, illumination, and fillet pigment. J. Food Sci. 60(2): 284-288. 
Black,D. and Love,R.M. 1988. Estimating carbohydrate reserves in fish. J. Fish Biology. 32(3): 335-340.

Bligh,E.G. and Duclos-Rendell,R. 1986. Chemical and physical characteristics of lightly salted minced cod (Gadus morhua). J. Food Sci. 51(1): 76-78.

Borderias,A.J., Moral,A., and Tejada,M. 1982. Stability of whole, filleted, and minced trout (Salmo irideus Gibb) during frozen storage. J. Food Biochem. 6(3): 187-195.

Center for Disease Control. 1979. Botulism in the United States, 1899-1977. In: Handbook for Epidermiologists, Clinicians and Laboratory Workers. Atlanta: Center for Disease Control. p. 25.

Chan,J.K., Gill,T.A., Thompson,J.W., and Singer,D.S. 1995. Herring surimi during low temperature setting, physicochemical and textural properties. J. Food Sci. 60(6): 1248-1253.

Christiansen,L., Deffner,J., Foster,E., and Sugiyama,H. 1968. Survival and outgrowth of Clostridium botulinum Type E spores in smoked fish. Appl. Microbiol. 16(1): 133-137.

Clarke,G.T.E., O'Neill,E.E., and O'Connor,T.P. 1994. Assessment and development of non-sensory techniques to monitor the quality of frozen Atlantic cod (Gadus morhua). In: Proceeding of the 24th annual food science and technology research conference. University College Cork, Ireland.

Connell,J.J. 1960. Changes in the actin of cod flesh during storage at $-14^{\circ}$. J. Sci. Food Agric. 11:515-519.

Connell,J.J. 1962. Changes in amount of myosin extractable from cod flesh during storage at $-14^{\circ}$. J. Sci. Food Agric. 13: 607-617.

Connell,J.J. and Howgate,P.F. 1968. Sensory and objective measurements of the quality of frozen stored cod of different initial freshness. J. Sci. Food Agric. 19(6): 342-354.

Crawford,L., Irwin,E.J., Spinelli,J., and Brown,W.D. 1970. Premortem stress and postmortem biochemical changes in skipjack tuna and their relation to quality of the canned product. J. Food Sci. 35(6): 849-851.

Damodaran,S. and Kinsella,J.E. 1982. Effects of ions on protein conformation and functionality. In: J.P.Cherry, editor. Food Protein Deterioration: Mechanisms and Functionality. Washington, D.C.:American Chemical Society. p. 327-357.

del Mazo,M.L., Torrejon,P., Careche,M., and Tejada,M. 1999. Characteristics of the salt-soluble fraction of hake (Merluccius merluccius) fillets stored at -20 and $-30^{\circ} \mathrm{C}$. J. Agric. Food Chem. 47(4): 1372-1377. 
Doe,P.E. 1982. Fish Drying \& Smoking: Production and Quality. Lancaster:Technomic Publishing Company, Inc. 250 p.

Dyer,W.J. and Dingle,J.R. 1961. Fish proteins with special reference to freezing. In: G.Borgstrom, editor. Fish as food. New York:Academic Press. p. 275.

Eklund,M.W., Peterson,M.E., Paranjpye,R., and Pelroy,G.A. 1988. Feasibility of a heat-pasteurization process for the inactivation of nonproteolytic Clostridium botulinum types $B$ and $E$ in vacuum-packaged, hot-process (smoked) fish. J. Food Prot. 51(9): 720-726.

Erikson,U., Beyer,A.R., and Sigholt,T. 1997. Muscle high-energy phosphates and stress affect K-values during ice storage of Atlantic salmon (Salmo salar). J. Food Sci. 62(1): 43-47.

Fennema,O. 1985. Food Chemistry. New York:Marcel Dekker Inc. 1067 p.

Ferguson,R.A., Kieffer,J.D., and Tufts,B.L. 1993. The effects of body size on the acid-base and metabolite status in the white muscle of rainbow trout before and after exhaustive exercise. J. Exp. Biol. 180: 195-207.

Foegeding,E.A., Lanier,T.C., and Hultin,H.O. 1996. Characteristics of edible muscle tissues. In: O.Fennema, editor. Food chemistry. New York:Marcel Dekker, Inc. p. 915.

Food and Drug Administration. 1997. Food and Drug Administration Compliance Program Guidance Munnual. 17 January, section 7303.842.

Fukumi,T., Tamoto,K., and Hidesato,T. 1965. Mon. Rep. Hokkaido Municipal Fish Exp. Stn. 22: 30. mentioned in Park,J.W., Lanier,T.C., Keeton,J.T., and Hamann,D.D. 1987. Use of cryoprotectants to stabilize funtional properties of prerigor salted beef during frozen storage. J. Food Sci. 52(3): 537-542.

Gill,T.A., Chan,J.K., Phonchareon,K.F., and Paulson,A.T. 1992. Effect of salt concentration and temperature on heat-induced aggregation and gelation of fish myosin. Food Res. Int. 25: 333-341.

Goeller,L.M. and Lanier,T.C. 2000. Optimization of infusion of low molecular weight cryoprotectants into intact muscle. IFT Annual Meeting Book of Abstracts. p. 23.

Gomez-Gilluen,M.C., Montero,P., Hurtado,O., and Borderias,A.J. 2000. Biological characteristics affect the quality of farmed Atlantic salmon and smoked muscle. J. Food Sci. 53(1): 60-65.

Hamm,R. 1960. Biochemistry of meat hydration. Adv. Food Res. 10: 355-463. 
Han,T.J. and Liston,J. 1989. Lipid oxidation protection factors in rainbow trout (Salmo gairdnerii) muscle cytosol. J. Food Sci. 54(4): 809-813.

Hansen,G.T., Nyvold,T.E., Solberg,T., and Ofstad,R. 1990. Frozen storage of various semi-processed products of Atlantic salmon. Science et Technique du froid. 211-217.

Hastings,R.J., Rodger,G.W., Park,R., Matthews,A.D., and Anderson,E.M. 1985. Differential scanning calorimetry of fish muscle: The effect of processing and species variation. J. Food Sci. 50(2): 503-506, 510.

Heinitz,M.L. and Johnson,J.M. 1998. The incidence of Listeria spp., Salmonella spp., and Clostridium botulinum in smoked fish and shellfish. J. Food Prot. 61(3): 318-323.

Hochachka,P.W. and Mommsen,T.P. 1983. Protons and anaerobiosis. Science. 219(4591): 1391-1397.

Hoshi,M., Sasamoto,Y., Nonaka,M., Toyama,K., and Watanabe,E. 1991. Microbial sensor system for nondestructive evaluation of fish meat quality. Biosensors and Bioelectronics. 6(1): 15-20.

Hsu,C.K., Kolbe,E., Morrissey,M.T., and Chung,Y.C. 1993. Protein denaturation of frozen Pacific whiting (Merluccius productus) fillets. J. Food Sci. 58(5): 10551056, 1075.

Huang,Y.W. 1983. Control of Clostridium botulinum outgrowth and toxin production using sodium chloride and additives. Ph.D. Abstract. University of Georia. FirstSearch-Dissertation Abstract Online:http://oclc.org.

Hultin,H.O., Stanley,D.W., and Feng,Y. 1995. A re-examination of muscle protein solubility. J. Muscle Foods. 6(2): 91-107.

Hurling,R. and Mcarthur,H. 1996. Thawing, refreezing and frozen storage effects on muscle functionality and sensory attributes of frozen cod (Gadus morhua). J. Food Sci. 61(6): 1289-1296.

Huston,A.H. and Madden,J.A.W.R.J. 1971. Variations in the blood and tissue chemistry of brook trout, Salvelinus fontinalis, subsequent to handling. J. Fish Res. Board Can. 28: 635-642.

Izquierdo-Pulido,M.L., Hatae,K., and Haard,N.F. 1992. Nucleotide catabolism and changes in texture indices during ice storage of cultured sturgeon, Acipenser transmontanus. J. Food Biochem. 16(2): 173-192.

Jerrett,A.R. and Holland,A.J. 1998. Rigor tension development in excised "rested", "partially exercised" and "exhausted" chinook salmon white muscle. J. Food Sci. 63(1): 48-52. 
Jerrett,A.R., Stevens,J., and Holland,A.J. 1996. Tensile properties of white muscle in rested and exhausted chinook salmon (Oncorhynchus tshawytscha). J. Food Sci. 61(3): 527-532.

Jiang,S.T., Lan,C.C., and Tsao,C.Y. 1986. New approach to improve the quality of minced fish products from freeze-thawed cod and mackerel. J. Food Sci. 51(2): 310-312, 351.

Jobling,M. 1994. Fish Bioenergetics. New York:Chapman \& Hall Inc. 309 p.

Johnson,I.A., Walesby,N.J., Davision,W., and Goldspink,G. 1975. Temperature adaptation in myosin of Antartic fish. Nature. 254(6): 74-75.

Kanner,J., Harel,S., and Joffe,R. 1991. Lipid prooxidation of muscle food as affected by NaCl. J. Agric. Food Chem. 39(6): 1017-1021.

Kenney,P.B., Kiser,R.A., Nayak,R., and Seymour,D.A. 1997. Brine exposure time, sodium chloride concentration, and thermal processing schedule affect quality of smoked rainbow trout. (not published).

Konno,K., Yamanodera,K., and Kiuchi,H. 1997. Solubilization of fish muscle myosin by sorbitol. J. Food Sci. 62(5): 980-984.

Korhonen,R.W., Lanier,T.C., and Giesbrecht,F. 1990. An evaluation of simple methods for following rigor development in fish. J. Food Sci. 55(2): 346-348, 368.

Kosak,P.H. and Toledo,R.T. 1981. Brining procedures to produce uniform salt content in fish. J. Food Sci. 46(3): 874-876.

Lakshmi,T.S. and Nandi,P.K. 1976. Hydrophobic interaction in sugar solutions: results from gel interaction study. J. Chromatography. 116(1): 177-179.

Lautenschlager,R. 1985. Diffusion of sodium chloride and sodium nitrite in raw meat model systems. In: Proceeding of the $41^{\text {st }}$ Int. Cong. Meat Sci. Tech. Vol. 2. San Antanio. p. 507-508.

Lee,C.M. 1984. Surimi process technology. Food Technology. 38(12): 69-80.

Lin,T.M. and Park,J.W. 1998. Solubility of salmon myosin as affected by conformational changes at various ionic strengths and $\mathrm{pH}$. J. Food Sci. 63(2): 215-218.

Lindsay,R.C. 1996. Food additives. In: O.Fennema, editor. Food Chemistry. New York Marcel:Dekker, Inc. p. 778-785.

Little,A.C. 1972. Effect of pre- and post-mortem handling on reflectance characteristics of canned skipjack tuna. J. Food Sci. 37(3): 502. 
Lockwood,S.J., Swift,D.J., Pawson,M.G., Eaton,D.R., Boutilier,R.G., and Aughton,P. 1981. Aspects of stress in mackerel. In: A.D.Pickering, editor. Stress and Fish. New York:Academic Press Inc. p. 347.

Lowe,T.E., Ryder,J.M., Carragher,J.F., and Wells,R.M.G. 1993. Flesh quality in snapper, Pagrus auratus, affected by capture stress. J. Food Sci. 58(4): 770-773, 796.

MacDonald,G.A. and Lanier,T.C. 1994. Actomyosin stabilization to freeze-thaw and heat denaturation by lactate salts. J. Food Sci. 59(1): 101-105.

MacDonald,G.A. and Lanier,T.C. 1997. Cryoprotectants for improving frozenfood quality. In: M.C.Erickson and Y.C.Hung, editors. Quality in Frozen Food. New York:Chapman \& Hall. p. 197-201.

MacDonald,G.A., Lanier,T.C., Swaisgood,H.E., and Hamann,D.D. 1996. Mechanism for stabilization $\mathrm{f}$ fish actomyosin by sodium lactate. J. Agric. Food Chem. 44(1): 106-112.

Maetz,J. 1969. Seawater teleosts: evidence for a sodium potassium exchange in the branchial sodium-excreting pump. Science. 166(3905): 613-615.

Mahon,J.H. and Schneider,C.G. 1964. Minimizing freezing damage and thawing drip in fish fillets. Food Technology. 18(12): 117-118.

Matsumoto,J.J. 1980. Chemical denaturation of muscle proteins during frozen storage. In: J.R.Whitaker and M.Fujiyama, editors. Chemical Denaturation of Proteins. ACS Sympos. Ser. 123. Washington, D.C.:American Chemical Society. p.95-124.

Mazeaud,M.M. and Mazeaud,F. 1981. Adrenergic responses to stress in fish. In: A.D.Pickering, editor. Stress and Fish. New York:Academic Press Inc. p. 65-67.

Mazeaud,M.M., Mazeaud,F., and Donaldson,E.M. 1977. Primary and secondary effects of stress in fish: Some new data with a general review. Tran. Am. Fish. Soc. 106(3): 201-212.

Miller,A.J., Ackerman,S.A., and Palumbo,S.A. 1980. Effects of frozen storage on functionality of meat for processing. J. Food Sci. 45(6): 1466-1471.

Mochizuki,S. and Sato,A. 1994. Effects of various killing procedures and storage temperatures on post-mortem changes in the muscle of horse mackerel. Nippon S. Gakkaishi. 60: 125-130.

Molin,R.A., Kraft,A.A., Walker,H.W., Rust,R.E., Olson,D.G., and Merkenich,K. 1987. Effect of inorganic polyphosphates on ground beef characteristics: some chemical, physical, and sensory effects on frozen beef patties. J. Food Sci. 52(1): 50-52. 
Montecchia,C.L., Roura,S.I., Roldan,H., Perez-Borla,O., and Crupkin,M. 1997. Biochemical and physicochemical properties of actomyosin from frozen pre- and post-spawned hake. J. Food Sci. 62(3): 491-495.

Moral,A., Tejada,M., and Borderias,A.J. 1986. Stability of frozen trout I. Treated and untreated minces stored at $-12,-18$, and $-24^{\circ} \mathrm{C}$. J. Food Biochem. 10(1): 3746.

Nakaya,M. and Watabe,S. 1995. Differences in the thermal stability of acclimation temperature-associated types of carp myosin and its rod on differential scanning calorimetry. Biochemistry. 34(9): 3114-3120.

Nakayama,T., Toyoda,T., and Ooi,A. 1994. Physical property of carp muscle during rigor tension generation. Fish. Sci., 60(6): 717-722.

Nakayama,T., Niwa,E., Hamada,I., and Shin,C. 1979. Viscosity changes of carp actomyosin solutions. J. Food Sci. 44 (4): 1106-1109.

Nilsson,K. and Ekstrand,B. 1995a. Sensory and chemically measured effects of different freeze treatments on the quality of farmed rainbow trout. J. Food Quality. 18(3): 177-191.

Nilsson,K. and Ekstrand,B. 1995b. Frozen storage and thawing methods affect biochemical and sensory attributes of rainbow trout. J. Food Sci. 60(3): 627-630, 635.

Nketsia-Tabiri,J. and Sefa-Dedeh,S. 1995. Optimization of process, conditions and quality of salted dried tilapia (Oreochromis miloticus) using response surface methodology. J. Sci. Food Agric. 69(1): 117-127.

Nuguchi,S. and Matsumoto,J.J. 1975. Studies on the control of the denaturation of the fish muscle proteins during frozen storage-IV. Preventive effect of carboxylic acids. Bull. Japan. Soc. Sci. Fish. 41(3): 329-335.

Ooizumi,T., Nara,Y., and Arai,K. 1984. Protective effect of carboxylic acids, sorbitol and $\mathrm{Na}$ (sodium)-glutamate on heat denaturation of chub mackerel myofibrils. Bull. Japan. Soc. Sci. Fish. 50(5): 875-882.

Owasu-Ansah,A.J. and Hultin,H.O, 1986. Chemical and physical changes in red hake fillets during frozen storage. J. Food Sci. 51(6): 1402-1406.

Park,J.W. and Lanier,T.C. 1987. Combined effects of phosphates and sugar or polyol on protein stabilization of fish myofibrils. J. Food Sci. 52(6): 1509-1513.

Park,J.W. and Lanier,T.C. 1989. Scanning calorimetric behavior of tilapia myosin and actin due to processing of muscle and protein purification. J. Food Sci. 54(1): 49-51. 
Park,J.W., Lanier,T.C., and Green,D.P. 1988. Cryoprotective effects of sugar, polyols, and/or phosphates on Alaska pollock surimi. J. Food Sci. 53(1): 1-3.

Park,J.W., Lanier,T.C., and Pilkington,D.H. 1993. Cryostabilization of functional properties of pre-rigor and post-rigor beef by dextrose polymer and/or phosphates. J. Food Sci. 58(3): 467-472.

Park,J.W., Lanier,T.C., Keeton,J.T., and Hamann,D.D. 1987. Use of cryoprotectants to stabilize functional properties of prerigor salted beef during frozen storage. J. Food Sci. 52(3): 537-542.

Pic,P., Mayer-Gostan,N., and Maetz,J. 1974. Brancial effects of epinephrinein the seawater-adapted mullet I. Water permeability. Am. J. Physiol. 226(3): 698702.

Pickering,A.D. 1981. Stress and Fish. New York:Academic Press Inc. 367 p.

Randall,D.J., Baumgarten,D., and Malysusz,M. 1972. The relationship between gas and ion transfer across gills of fishes. Comp. Biochem. Physiol. 41A: 629637.

Rhee,K.S., Smith,G.C., and Terrell,R.N. 1983. Effect of reduction and replacement of sodium chloride on rancidity development in raw and cooked ground pork. J. Food Prot. 46(7): 578-581.

Richards,B.D. and Fromm,P.O. 1970. Sodium uptake by isolated-perfused gills of rainbow trout, Salmo gairdneri. Comp. Biochem. Physiol. 33: 303-310.

Saito,T., Arai,K., and Matsuyoshi,M. 1959. A new method for estimating the freshness of fish. Bull. Japan. Soc. Sci. Fish. 24: 749-750.

Sigholt,T., Erikson,U., Rustad,T., Johansen,S., Nordtvedt,T.S., and Seland,A. 1997. Handling stress and storage temperature affect meat quality of farmedraised Atlantic salmon (Salmo salar). J. Food Sci. 62(4): 898-905.

Sikorski,Z.E., Olley,J., and Kostuch,S. 1976. Protein changes in frozen fish. Crit. Rev. Food Sci. Nutr. 8(1): 97-129.

Srinivasan,S. and Xiong,Y.L. 1996. Gelation of beef heart surimi as affected by antioxidants. J. Food Sci. 61(4): 707-711.

Srinivasan,S. and Xiong,Y.L. 1997. Sulfhydryls in antioxidant-washed beef heart surimi. J. Muscle Foods. 8(3): 251-263.

Srinivasan,S., Xiong,Y.L., Blanchard,P., and Tidwell,J.H. 1997. Physicochemical changes in prawns (Machrobrachium rosenbergii) subjected to multiple freezethaw cycles. J. Food Sci. 62(1): 123-127. 
Stevens,E.D. 1968. The effect of exercise on the distribution of blood to various organs in rainbow trout. Comp. Biochem. Physiol. 25: 615.

Strange,R.J., Schreck,C.B., and Golden,J.T. 1977. Corticoid stress responses to handling and temperature in salmonids. Tran. Am. Fish. Soc. 106(3): 213-218.

Tang,Y. and Boutilier,R.G. 1991. White muscle intracellular acid-base and lactate status following exhaustive exercise: a comparison between fresh water- and seawater-adapted rainbow trout. J. Exp. Biol. 156: 153-171.

Tejada,M., Borderias,A.J., and Moral,A. 1986. Stability of frozen trout II. Different trout preparations stored at $-18^{\circ} \mathrm{C}$. J. Food Biochem. 10(1): 47-53.

Trout,G.R. and Schmidt,G.R. 1983. Utilization of phosphate in meat products. In: Proceeding of the $36^{\text {th }}$ Annual Reciprocal Meat Conference. Chicago:National Livestock and Meat Board. p. 24-27.

Tsuchiya,H., Kita,S., and Seki,N. 1992. Postmortem changes in a-actinin and connectin in carp and rainbow trout muscles. Nippon S. Gakkaishi. 58: 793-798.

Turner,S.R., Flick,G.J., Duncan,S.E., Haugh,C.G., and Conforti,F.D. 1995a. The efficacy of natural antioxidant blends to control oxidative rancidity in filleted and headed and gutted Rainbow trout (Oncorhynchus mykiss) during frozen storage. Abstract. Virginia Polytech. Inst. and State U., Blackburg, VA. VT Publications no. 178.

Turner,S.R., Flick,G.J., Duncan,S.E., Haugh,C.G., and Conforti,F.D. 1995b. The efficacy of using natural antioxidant blends to control oxidative rancidity in minced Rainbow trout (Oncorhynchus mykiss) during frozen storage. Abstract. Virginia Polytech. Inst. and State U., Blackburg, VA. VT Publications no. 179.

Wang,B., Xiong,Y.L., and Srinivasan,S. 1997. Chemical stability of antioxidantwashed beef heart surimi during frozen storage. J. Food Sci. 62(5): 939-945, 991.

Wang,D.Q. and Kolbe,E. 1990. Thermal conductivity of surimi-Measurement and modeling. J. Food Sci. 55(5): 1217-1221, 1254.

Watabe,S., Hwang,G.C., Nakaya,M., Guo,X.F., and Okamoto,Y. 1992. Fast sketetal myosin isoforms in thermally acclimated carp. J. Biochem. 111(1): 113122.

Wood,C.M. and Perry,S.F. 1985. Respiratory, circulatory, and metabolic adjustments to exercise in fish. In: R.Gilles, editor. Circulation, Respiration, Metabolism. Berlin:Springer-Verlag. p. 2-22. 
Wooton,M. and Ismail,N. 1986. The influence of processing conditions on the properties of dried Nemadectylus macropterus fillets. J. Sci. Food Agric. 37(4): 399-408.

Zotos,A., Hole,M., and Smith,G. 1995. The effect of frozen storage of mackerel (Scomber scombrus) on its quality when hot-smoked. J. Sci. Food Agric. 67(1): 43-48. 


\section{CHAPTER 1}

\section{EFFECT OF BRINE CONCENTRATION AND BRINING TIME ON QUALITY OF SMOKED RAINBOW TROUT, Oncorhynchus mykiss, FILLETS}




\section{ABSTRACT}

Brining is the most important step in smoked fish processing. Optimizing brine concentration and brining time should optimize the balance of proteinprotein and protein-water interactions, texture development, processing yields, product quality, and product safety. Rainbow trout, Oncorhynchus mykiss, fillets that had been frozen for $78 \mathrm{~d}$ were thawed and brined in 8.7 or $17.4 \%(\mathrm{w} / \mathrm{v})$ sodium chloride solution, respectively, for $30,60,90$, or 120 min at $3^{\circ} \mathrm{C}$. Light brown sugar was added to equal $69 \%(\mathrm{w} / \mathrm{w})$ of the sodium chloride required for the brine. A $2 \times 4$ factorial, randomized complete block design with day as block was used. Eight treatments were replicated three times on three separate days. Brined fillets were smoked in a microprocessor-controlled smokeoven to an internal temperature of $65.5^{\circ} \mathrm{C}$ and held for $50 \mathrm{~min}$. Trout mince was also prepared from each treatment. This mince was used for texture (hardness and cohesiveness) and protein solubility (total soluble and myofibrillar proteins) evaluations. Brine uptake, brined and cooked $\mathrm{pH}$, cook yield, shear force, water activity, water-phase salt content, and brined and cooked proximate composition were measured on trout fillets. Increasing brine concentration increased $(p<0.05)$ fillet weight loss after brining, cook yield, water-phase salt content, shear force, brined fat, brined and cooked ash and decreased $(p<0.05)$ water activity, brined $\mathrm{pH}$, brined and cooked moisture. Brining time linearly increased $(\mathrm{p}<0.05)$ myofibrillar protein solubility, fillet weight loss after brining, total and water-phase salt content, and cooked ash content and linearly decreased water activity, brined and cooked moisture content. A quadratic relationship existed $(p<0.05)$ 
between brining time and shear force, with a maximum force at 90 min. At $8.7 \%$ brine, quadratic relationships were observed $(p<0.05)$ between hardness and cohesiveness, and brining time with maximum hardness and cohesiveness at 90 min. Total soluble proteins and cooked $\mathrm{pH}$ were not affected $(\mathrm{p}>0.05)$ by treatment. An $8.7 \%(\mathrm{w} / \mathrm{v})$ brine concentration and $90-\mathrm{min}$ brining time resulted in maximum texture development while achieving the water-phase salt content $(\geq$ 3.5\%) required by the Food and Drug Administration.

Keywords: trout, brining protocol, smoked fish. 


\section{INTRODUCTION}

Trout is the second largest farmed fish produced in the United States. Total sales, excluding eggs, reached nearly 72 million dollars during 1999, an

increase of 4.7\% from 1998 (National Agricultural Statistics Service, 2000). In terms of overall sales, foodsize fish (12 inches and longer) accounted for $84 \%$. Within this number, 64 percent were sold to processors (Economic Research Service, 2000). Production of food fish is poised to become an important aquaculture enterprise in the Northeast region of the United States. Most processed fish are sold to retail market as fillets, steaks, strips, and nuggets in fresh and frozen forms. Nonetheless, other technologies, such as curing and smoking, can be used to add value to fish as a raw material for muscle foods. These technologies expand marketing opportunities for this raw material.

Outbreaks of botulism and the incidence of Listeria spp. and Salmonella spp. in smoked fish have been reported for over 30 years (Anonymous, 1963; Center for Disease Control, 1979; Heinitz and Johnson, 1998; Heinitz et al., 2000); outgrowth of these organisms may be due to insufficient salt and temperature abuse during distribution. To minimize the risk of botulism, waterphase salt in vacuum packed, hot-smoked fish must be at least $3.5 \%$ when no nitrite is added (Food and Drug Administration, 1997). Therefore, brine concentrations that range from 15 to $24 \%(\mathrm{w} / \mathrm{v})$ salt or a long brining time is used to achieve greater than or equal to $3.5 \%$ water-phase salt. However, smoked products that have too much salt are unacceptable to most consumers (Christiansen et al., 1968; Nketsia-Tabiri and Sefa-Dedeh, 1995) and are of 
concern as a risk factor in hypertension (Astawan et al., 1994; Whitney and Rolfes, 1996).

Salt promotes dehydration of muscle proteins, altering the balance of protein-protein and protein-water interactions. The challenge associated with fish curing and smoking is optimal texture development at a water phase salt content that limits growth of spoilage and pathogenic organisms and complies with regulatory guidelines. Therefore, in the context of the hypothesis that increased brine concentration and brining time will promote protein-protein interactions and decrease protein-water interactions, the objectives for this study were to determine: 1) the effect of brine concentration and brining time on protein-water interactions and relate degree of interaction to texture and 2) the effect of brine concentration and brining time on water-phase salt content in smoked product and relate this to safety.

\section{MATERIALS AND METHODS}

\section{Fish samples}

Seventy-two rainbow trout, Oncorhynchus mykiss, were not fed for $3 \mathrm{~d}$ prior to harvest. At harvest, fish $(515.0 \pm 70.8 \mathrm{~g})$ were packed on ice and transported to the West Virginia University meats laboratory for processing within $4.5 \mathrm{~h}$ or harvest. Following filleting, the "fillet" is described as a butterfly fillet. Fillets were vacuum packed (Ultravac ${ }^{\circledR}$, Model UV500, Koch; Kansas City, MO) in polyethylene bags, frozen in a blast freezer, and stored for $78 \mathrm{~d}$ at $-20^{\circ} \mathrm{C}$. 


\section{Brining protocol}

After thawing overnight at $3^{\circ} \mathrm{C}$, fillets were soaked in a separate container containing 8.7 or $17.4 \%(\mathrm{w} / \mathrm{v})$ sodium chloride for $30,60,90$, or 120 min at $3^{\circ} \mathrm{C}$. The $8.7 \%$ concentration was used as a typical industry brine. Three fillets were used in each treatment combination. Light brown sugar was added at $69 \%(\mathrm{w} / \mathrm{w})$ of the sodium chloride required for the brine. A fillet to brine ratio of 1 fillet $(340 \pm 50 \mathrm{~g})$ to $1.4 \mathrm{~L}$ of brine was used. Following brining, fillets were drained and placed on stainless steel expanded metal racks with skin down for $24 \mathrm{~h}$ at $3^{\circ} \mathrm{C}$. This time was chosen to allow brine equilibration and pellicle formation. Fillets were covered with polyethylene wrap $4 \mathrm{~h}$ after draining to prevent excessive drying.

\section{Thermal processing}

Brined fillets were smoked in a microprocessor-controlled smokeoven (Enviro-Pak, Model CVU-490; Clackamas, OR) to an internal temperature of $65.5^{\circ} \mathrm{C}$ and held for $50 \mathrm{~min}$. The heating process met the minimum requirement of the FDA Fish and Fishery Products Hazards and Controls Guide, 21 CFR 123 (Federal Register, 1995). Total cooking time was $4 \mathrm{~h}$. After cooking, fillets were cooled at ambient temperature for $30 \mathrm{~min}$, at $3^{\circ} \mathrm{C}$ for an additional $30 \mathrm{~min}$, and packed in polyethylene bags. Samples were aerobically stored at $3^{\circ} \mathrm{C}$, and analyses were carried out within $24 \mathrm{~h}$. Cooked fillets were used to measure shear force, total and water-phase salt content, $\mathrm{pH}$, water activity, and proximate composition. 


\section{Gel processing}

One brined fillet from each treatment was skinned and minced in a Cuisinart ${ }^{\circledR}$ food processor for three, 15-s intervals, interrupted by two, 15-s intervals. Mince was stuffed into two, 2.8-cm (ID), 50-mL polypropylene centrifuge tubes. Following stuffing, tubes were placed in a $45^{\circ} \mathrm{C}$ water bath until the internal gel temperature reached $42^{\circ} \mathrm{C}$. At this time, water temperature was increased to $72^{\circ} \mathrm{C}$, and gels were removed from the water bath when the internal temperature reached $65.5^{\circ} \mathrm{C}$. Endpoint internal cooking temperature was monitored with a Beckman Industrial Datalogger (Model 205, Beckman Instruments; Fullerton, CA) equipped with a copper-constant thermocouple (Omega Technologies; Stamford, CT). Total cooking time was 45 min. After cooking, gels were cooled to ambient temperature before transfer to $4^{\circ} \mathrm{C}$. Gels were used for texture profile analysis, and the remaining raw mince was used for determination of total soluble proteins, myofibrillar protein solubility, and proximate composition.

\section{Sample preparation for proximate composition}

For raw muscle, three fish fillets were used for proximate analysis. Fillets were skinned, cut into small pieces (excluding belly flap), frozen in liquid nitrogen, and powdered in a pre-chilled commercial Waring Blender for 2-3 min. Following stuffing, the remaining raw mince was also powdered with liquid nitrogen for subsequent analyses. Following shear test, the remaining cooked whole fillets were skinned, cut into small pieces, and chopped in a Cuisinart ${ }^{\circledR}$ 
food processor for $45 \mathrm{~s}$. Samples were stored at $-20^{\circ} \mathrm{C}$ until analyses were performed.

\section{Chemical and physical analysis}

Proximate composition: Proximate composition was determined using AOAC (1990) approved methods.

pH: Sample pH was measured using a pH/ion analyzer 350 (Corning Inc.; Corning, NY) equipped with a flat surface combination probe. The $\mathrm{pH}$ was measured on brined fillets at the cranial, middle, and caudal areas above the lateral line. These values were averaged and used as the observation for that sample. For chopped, cooked samples, five grams were mixed with $50-\mathrm{mL}$ distilled water before analyzing $\mathrm{pH}$ with a general purpose combination probe.

Brine uptake and cook yield: Individual fillets were weighed before brining, after brining, and after cooking. Brine uptake was calculated as the difference between the before and after brining weights. Brined and cooked weights were expressed as a percent of the weight before brining. For the fish mince, individual gels were lightly rolled over filter paper to remove excess moisture and weighed to determine cooked weight. Cook yield was calculated as cooked weight expressed as percent of raw weight.

Total and water-phase salt content: Salt content of cooked fish was determined by the Indicating Strip Method (No. 971.19; AOAC, 1990). This method uses the Quantab ${ }^{\circledR}$ chloride titrator (Environmental Test Systems, Inc.; Elkhart, IN), No.711196, and it has a range of 0.05 to $1.0 \%$ sodium chloride. After 9:1 dilution, the effective sodium chloride range of the product is 0.5 to 
$10 \%$. Ten grams of chopped, cooked sample were mixed with $90 \mathrm{~mL}$ of hot water. The slurry was filtered through Whatman No. 41 filter paper, and sodium chloride content was calculated by multiplying the strip reading for sodium by 10 . Moisture content was determined by drying a 3-g sample at $103 \pm 1^{\circ} \mathrm{C}$ for $24 \mathrm{~h}$. Percent water-phase salt was calculated as (g sodium chloride $\times 100$ ) / (g sodium chloride $+\mathrm{g}$ moisture) (Heinitz and Johnson, 1998).

Water activity (Aw): A water activity meter (Aqua Lab, Model CX-2, Decagon Devices, Inc.; Pullman, WA) was used to measure Aw of chopped, cooked fish at $25 \pm 1^{\circ} \mathrm{C}$.

Protein quantification: Ten grams of raw, minced sample were blended with $50 \mathrm{~mL}$ of $3.8 \%(\mathrm{w} / \mathrm{v})$ sodium chloride (ionic strength 0.65 ) in a Stomacher 400 blender (Tekmar; Cincinnati, $\mathrm{OH}$ ) for $30 \mathrm{~s}$. This aqueous-phase salt concentration was calculated based on the estimated salt content in brined fillets (3\%) containing $76 \%$ moisture content. The slurry was then centrifuged for 30 min at $4^{\circ} \mathrm{C}$ in a Damon IEC B200A (870 head, $8 \times 50 \mathrm{~mL}$ tubes) refrigerated centrifuge (Fisher Scientific Co.; Pittsburgh, PA) at 7000xg, as measured at the top of the centrifuge tube. Supernatant was filtered two times through Whatman No. 41 filter paper. Soluble protein concentration was determined by the Biuret method using bovine serum albumin as the standard (Gornall et al., 1949). Myofibrillar proteins (soluble myosin and actin) were separated using sodium dodecyl sulfate, polyacrylamide gel electrophoresis (SDS-PAGE) (Greaser et al., 1983). A vertical slab gel system (Hoefer Scientific Instruments; San Francisco, CA) was used to prepare $1.5 \mathrm{~mm}$-thick gels. Appropriate quantities of protein 
extract, sample buffer (0.7 M 2-mercaptoethanol; 3\% SDS; $0.05 \mathrm{M}$ tris buffer, $\mathrm{pH}$ 6.8) and $10 \%$ bromophenol blue: glycerol were combined to give a final protein concentration of $1 \mathrm{mg} / \mathrm{mL}$. Twenty microliters of the standardized sample (20 $\mu \mathrm{g}$ protein) were loaded in alternating wells of a $3 \%$ stacking gel, and sample buffer was loaded in empty wells to minimize band diffusion. Ten $\mu \mathrm{L}$ of high (212-40 $\mathrm{kDa})$ and low (31-2.5 kDa) molecular weight markers (Sigma Chemical Co.; St. Louis, MO) were loaded on the left side of each gel, and $5 \mu \mathrm{g}$ each of actin and myosin standard (Sigma Chemical Co.; St. Louis, MO) were loaded on the right side of each gel. A $15 \%$ bis-acrylamide resolving gel was used to separate protein bands. Electrophoresis was conducted at a constant current of $20 \mathrm{~mA}$ per slab until the tracking dye reached the resolving gel, and current was then increased to $30 \mathrm{~mA}$ per slab. Electrophoresis proceeded until the marker dye was $4 \mathrm{~cm}$ from the bottom of the gel. Gels were fixed in $10 \%(\mathrm{w} / \mathrm{v})$ trichloroacetic acid (TCA) for $20 \mathrm{~min}$, stained in a $0.05 \%(\mathrm{w} / \mathrm{v})$ Coomassive brilliant blue G-250 (Eastman Kodak Co.; Rochester, NY), 50\% (v/v) methanol, and 9.2\% (v/v) glacial acetic acid solution for $4 \mathrm{~h}$. Gels were subsequently destained in a solution containing $10 \%(\mathrm{v} / \mathrm{v})$ methanol and $7.5 \%(\mathrm{v} / \mathrm{v})$ glacial acetic acid until the background was clear. Destaining procedures for all gels were standardized. All other reagents used were analytical grade. Following destaining, gels were placed on an illuminator (Northern Light Precision Illuminator Model B90, Imaging Research Inc.; St. Catherines, Ontario, Canada) at a wavelength of $500 \mathrm{~nm}$. Gel images were captured on a video camera (CCD 72, Dage-MTI; Michigan City, IN) for entry into the Optimas Image Analysis system (Optimas Inc.; Edmonds, WA). 
Individual bands of myosin and actin were magnified 200\%, and the perimeter around each band was marked. Gray values of the marked areas were determined, and the inverse log integrated gray value (ILIGV) of sample myosin and actin areas was correlated to the ILIGV for myosin and actin standards in order to quantify these proteins in the sample. Gel background was accounted by calculating the mean ILIGV at six positions on the gel and subtracting this mean background from ILIGV of myosin and actin standards and samples. Soluble myosin and actin ( $\mu \mathrm{g} / \mathrm{mL}$ sample buffer) were calculated as (mean ILIGV; $\mu \mathrm{g} / \mathrm{mL}$ sample buffer) $\times(50$; dilution factor).

Texture characteristics: Fish gel texture was evaluated according to Texture Profile Analysis (Bourne, 1978) using an Instron Universal Testing Machine (Model TM, Instron Corp.; Canton, MA). Gels were cut into cores (1.91 $\mathrm{cm}$ diameter, $1.27 \mathrm{~cm}$ high). Each core was axially compressed at $127 \mathrm{~mm} / \mathrm{min}$ to $50 \%$ of its original height for two cycles in order to determine peak force (hardness) of the first compression cycle and cohesiveness. Cohesiveness is defined as the ratio of positive peak force area during the second compression to that of the first compression (Bourne, 1978). A 50-kg load cell (Model 1520.50, Daytronic; Miamisburg, $\mathrm{OH}$ ) was used as a top plate and a stainless steel base was the other plate. Output signal was sent to a computer equipped with a DT 2805 data acquisition board (Data Translation Inc.; Marlboro, MA) via a Daytronics mainframe equipped with a LVDT conditioner (Model 9130, Daytronic; Miamisburg, $\mathrm{OH}$ ). A $2.54 \times 10 \mathrm{~cm}$ section of the dorsal musculature was cut for fillet texture analyses. Shear force was measured with a Warner-Bratzler shear 
attachment using an Instron Universal Testing Machine and output signal was processed as previously described. Each piece was skinned, and placed beneath the blade with the pellicle side down. Each piece was sheared at 2.54$\mathrm{cm}$ intervals along the length of the strip. These values were averaged and used as the observation for that fillet.

\section{Experimental design}

A two by four factorial, randomized complete block design with day as block was used. Eight treatment combinations, resulting from two brine concentrations ( 8.7 and $17.4 \%(\mathrm{w} / \mathrm{v})$ sodium chloride) and four brining times (30, 60,90 , and $120 \mathrm{~min}$ ) were replicated three times on three separate days. Data were analyzed using the General Linear Model (GLM) procedure of SAS (SAS Institute, Inc., 1989) to establish main and interaction effects. Brine concentration means were separated using the PDIFF of the Ismeans procedure. Orthogonal polynomials were performed to evaluate linear $(-3-1+1+3)$, quadratic $(+1-1-1+1)$, and cubic $(-1+3-3+1)$ relationships between brining time and response variables at a significance level of $p<0.05$.

\section{RESULTS AND DISCUSSION}

pH

The high brine concentration $(17.4 \%)$ decreased $(\mathrm{p}<0.05)$ brined $\mathrm{pH}$ compared to the low brine concentration (8.7\%) (Table 1). Nayak and coworkers (1996) reported that extract $\mathrm{pH}$ decreased from 6.06 to 5.58 in turkey breast muscle and from 6.12 to 5.70 in thigh muscle as sodium chloride concentration 
increased from 0 to $4 \%(\mathrm{w} / \mathrm{v})$. The increase in brining time from 30 to $120 \mathrm{~min}$ did not affect $(p>0.05)$ brined $\mathrm{pH}$ (Table 1$)$.

Cooked $\mathrm{pH}$ was higher than brined $\mathrm{pH}$; however, brine concentration and brining time did not affect cooked $\mathrm{pH}(\mathrm{p}>0.05)$.

\section{Total protein solubility}

Total protein solubility was not affected $(p>0.05)$ by brine concentration and brining time (Table 1). However, total protein solubility was reduced, but not significantly, as brine concentration and brining time increased. Nayak and coworkers (1996) found that protein solubility increased by $25 \%$ in turkey breast muscle and $47 \%$ in thigh muscle as sodium chloride increased from 0 to $4 \%$ $(w / v)$. They also indicated that this increase was probably associated with solubility of myofibrillar proteins. In this study, total protein solubility decreased while myosin and actin solubility increased. This may be caused by the effect of sodium chloride on the salting-out of other proteins that, in turn, decreased total protein solubility.

\section{Myosin solubility}

There was a brine concentration and brining time interaction for myosin solubility $(p<0.05)$. However, as brining time increased for both brine concentrations, myosin solubility linearly increased $(p<0.05$; Figure 1$)$. Ionic strength is estimated (Table 2) for raw and cooked fish muscle at each brine concentration and brining time treatment combination. Myofibrillar proteins are generally soluble at 0.3 to $0.6 \mathrm{M}$ sodium chloride (Hultin et al., 1995). The lower myosin solubility at a higher brine concentration may be due to the higher ionic 
strength in raw fish muscle that promotes salting-out of myosin. Sodium chloride increased myosin and actin solubility in the lower brine concentration, particular myosin, perhaps by enhancing electrostatic repulsion (Hamm, 1960) and dissociating myosin aggregates (Siegel and Schmidt, 1979).

\section{Actin solubility}

The higher brine concentration increased $(p<0.05)$ actin solubility, and as brining time increased, actin solubility linearly increased $(p<0.05$; Table 1$)$. Increased ionic strength up to 0.90 for the $17.4 \%$ brine concentration and 120 min brining time (Table 2) did not affect salting-out of actin, even though myofibrillar proteins are generally soluble at 0.3 to $0.6 \mathrm{M}$ sodium chloride (Hultin et al., 1995).

\section{Brine uptake}

The higher brine concentration caused $(p<0.05)$ dehydration of the fillets (Table 3). Fillets soaked in the high brine concentration lost their weight due to the difference in solute concentration between the brine solution and inherent muscle water; water migrated from fish muscle to the brine solution. Moreover, soaking in the high brine solution may cause salting-out of proteins on the fillet surface that led to precipitation and dehydration of proteins and, in turn, exclusion of water molecules. Nketsia-Tabiri and Sefa-Dedeh (1995) indicated that denaturation of muscle protein facilitated diffusion of water from fish. Decreased brine uptake corresponded with decreased moisture content of brined and cooked fillets. Bligh and Duclos-Rendell (1986) reported that released brine (by vacuum filter press) increased as salt concentration increased from 5 to $28 \%$ 
$(w / w)$ in minced cod. A rapid increase in water loss was observed when more than $9 \%$ salt was reached in the muscle. These data are in agreement with our results confirming that water holding capacity of fish flesh decreases with an increasing salt content.

Brining time linearly increased fillet dehydration $(p<0.05$; Table 3$)$. Lautenschlager (1985) reported that diffusion of salt ions through a meat slice was a very slow process, and it was a function of time. Diffusion occurs until sodium chloride concentration of the system (fish and brine) has equilibrated. A linear relationship in this system indicated that 120-min brining time was not enough for sodium chloride equilibration. In other words, an asymptotic minimum moisture content was not achieved.

\section{Cook yield}

The $17.4 \%$ brine resulted in greater cook yield than did the $8.7 \%$ brine $(p<0.05$; Table 3$)$. The high brine concentration decreased moisture content of both brined and cooked fillets. This increased cook yield may be due to less moisture in the high-brined fillets prior to thermal processing. Therefore, there was less water to lose during heating. Brining time did not affect $(p>0.05)$ cook yield of smoked fillets (Table 3 ).

There was an interaction between brine concentration and brining time on mince cook yield $(p<0.05)$. At a high brine concentration, brining time did not affect mince cook yield ( $p>0.05$; Figure 2). In contrast, at the low brine concentration there was a quadratic relationship between brining time and mince cook yield $(p<0.05)$; mince cook yield at 60 min had the minimum value. Many 
factors influence mince cook yield. Usually, high protein solubility leads to an increase in cook yield due to the increased number of soluble proteins present to unfold, leading to protein-protein and protein-water interactions and aggregation in the gelation process (Cheftel et al., 1985). However, Cheftel and coworkers (1985) indicated that soluble proteins are not always a prerequisite for gelation. Some aqueous or saline dispersions of insoluble or slightly soluble proteins, such as collagen and some myofibrillar proteins, may also form gels. Generally muscle protein gelation occurs in a three-step process as follows: 1) dissociation of myofibrillar structures during solubilization in the presence of high salt concentration, 2) partial unfolding of the protein structure due to increasing temperature, and 3) aggregation of unfolded regions, via hydrogen and disulfide bonds and electrostatic and hydrophobic interactions, to form a threedimensional network (Stone and Stanley, 1992). Hermansson (1978) stated that the slower that protein aggregation was relative to partial unfolding of proteins, the better the denatured chains orient themselves, and the finer the gel network. The variation in gel cook yield for various treatment combinations perhaps was caused by the composition of soluble proteins, a change in protein conformation, and the proportion of soluble and insoluble proteins. In addition, differences in viscosity affect heating rate. In some cases, an increase in aggregation may have occurred so rapidly that the protein did not have an adequate time to unfold and form a proper matrix to hold water. 


\section{Total and water-phase salt content}

Salt preserves fish by dehydrating tissue, increasing water-phase salt, and decreasing water activity. There was a brine concentration by brining time interaction for salt content of smoked products $(p<0.05)$. In general, brining time linearly increased salt content from 30 to $120 \mathrm{~min}(p<0.05$; Figure 3$)$. Salt content of products soaked in higher brine concentration were greater than those from lower brine concentration at the same brining time. Nketsia-Tabiri and Sefa-Dedeh (1995) reported that salting time was a significant variable influencing product salt content.

Increasing brine concentration increased $(p<0.05)$ water-phase salt content of smoked fillets, and brining time linearly increased $(p<0.05)$ waterphase salt content (Table 3). Increased water-phase salt content corresponded with decreased water activity and increased product ash content.

\section{Water activity}

Water activity of smoked products decreased $(p<0.05)$ as brine concentration increased (Table 3$)$. Brining time linearly decreased $(p<0.05)$ water activity (Table 3).

\section{Texture}

$\underline{\text { Fillet }}$

Shear force was greater $(p<0.05)$ for the high brine concentration than the low brine concentration (Table 3) because of the lower moisture content that made smoked fillet texture firmer. Texture of fish muscle has been related to water content and lipid content. Dunajski (1979) stated that water and lipid 
lowered muscle strength; fish higher in lipid or moisture content were softer in texture. Takahashi (1960) also stated that muscle of species with less water and a higher protein became firmer following cooking. Foegeding and coworkers (1996) indicated that, in fish muscle, relative firmness of cooked fish meats has been related primarily to muscle $\mathrm{pH}$ and water content. Hatae and coworkers (1990) reported muscle fiber size and the amount of coagulated sarcoplasmic proteins in the interstitial region between individual muscle fibers could explain the tenderness difference of cooked fish muscle. Smaller fibers, especially when they are immobilized in a coagulum of exuded sarcoplasmic proteins, impart a firm cooked texture.

A quadratic relationship $(p<0.05)$ between shear force and brining time was observed; the 90-min brining time had the maximum shear force (Table 3). Increased shear force from 30 to 90 min corresponded to decreased cooked moisture content. Nketsia-Tabiri and Sefa-Dedeh (1995) reported that salting time influenced sensory hardness of salted-dried tilapia. Salting of tilapia caused moisture losses, and increased salt content. Texture development may be initiated during the salting process. Drying provided a second stage of product quality development. According to their suggestion and the findings of Foegeding and coworkers (1996), increased myosin and actin solubility may be involved in shear force increases from 30 to 90 min. A lower shear force at 120 min compared to that at 90 min may due to a higher product fat content at 120 $\min$. 
Mince

There was an interaction between brine concentration and brining time regarding cooked mince hardness $(p<0.05)$. At the low brine concentration, there was a quadratic relationship between brining time and mince hardness; and at 90 min hardness was maximized $(p<0.05$; Figure 4). A different result was observed at the high brine concentration; a cubic relationship was evident between mince hardness and brining time $(\mathrm{p}<0.05)$.

A brine concentration by brining time interaction was observed for cooked mince cohesiveness $(p<0.05)$. At the low brine concentration, there was a quadratic relationship between brining time and cohesiveness, with maximum cohesiveness at $90 \mathrm{~min}(\mathrm{p}<0.05$; Figure 5$)$. At the high brine concentration, a cubic relationship was observed between brining time and mince cohesiveness $(p<0.05)$.

At $8.7 \%$ brine, increases in hardness and cohesiveness followed the same pattern with regard to brining time, and generally corresponded to increased myosin solubility. However, the highest myosin solubility at this brine concentration did not produce the maximum hardness and cohesiveness. At $17.4 \%$ brine, hardness and cohesiveness followed the opposite pattern of brining time, and traits did not relate to increased myosin solubility. Factors other than protein concentration are important to texture development at $17.4 \%$ brine. Three physicochemical events impact meat protein functional properties in comminuted products. These events are: 1) protein-water interaction, 2) proteinprotein aggregation, and 3) protein-fat association (Acton et al., 1983). 
Environmental factors, such as $\mathrm{pH}$, ionic strength, and protein conformation, that alter the balance of these interactions may influence hardness and cohesiveness of cooked mince. Hastings and coworkers (1985) reported decreased myosin transition temperature and endothermic heat when herring was soaked in $14 \%$ salt. Increased myosin susceptibility to thermal denaturation may rapidly increase aggregation of protein during the gelation process that affects texture development.

\section{Proximate composition}

Prior to any manipulations, average raw fillet composition was $76.24 \%$ moisture, $18.76 \%$ protein, $3.69 \%$ fat, and $1.30 \%$ ash.

Composition of raw, brined fillets was determined after the brining step and following smoking-cooking, cooked composition was determined. Moisture content of brined fillets (Table 4) was less than that of raw fillet. Increasing brine concentration decreased $(p<0.05)$ moisture content of both brined and cooked fillets (Tables 4 and 5). Brining time linearly decreased $(p<0.05)$ moisture content of both brined and cooked fillets (Tables 4 and 5). Nketsia-Tabiri and Sefa-Dedeh (1995) concluded that salting time was the most important processing variable influencing product moisture content. Fish salting leads to a reduction in moisture that has been attributed to the denaturing effect of salt on fish proteins. However, they showed that at each drying temperature there was a critical salting time for achieving minimum moisture levels. The plot between moisture content and prolonged salting time provided a U-shaped curve. 
Fat content of brined fillets increased $(p<0.05)$ with increased brine concentration (Table 4). However, fat content was not different ( $p>0.05)$ after cooking (Table 5). Increased salt promoted protein-protein interactions and decreased protein-water interactions that, in turn, decreased the ability of cooked muscle to hold fat. A Longer brining time did not affect $(p>0.05)$ brined and cooked fat content (Tables 4 and 5).

Protein content of brined fillets (Table 4) was lower than that of raw muscle. Nketsia-Tabiri and Sefa-Dedeh (1995) reported that salting of tilapia caused losses in some macromolecules, including proteins. Protein content of raw, salted, minced cod decreased inversely with increased salt addition (Bligh and Duclos-Rendell, 1986). In this present study, brine concentration and brining time did not affect ( $p>0.05)$ brined and cooked protein content (Tables 4 and 5). This discrepancy may be due to the difference between intact fillet and minced muscle.

Ash content of brined fillets (Table 4) was much higher than that of raw fillet. Increased brine concentration increased $(p<0.05)$ brined and cooked product ash content (Tables 4 and 5). Water losses associated with brining resulted in increased ash content. Brining time did not affect $(p>0.05)$ ash content of brined fillets but linearly increased $(p<0.05)$ ash content of cooked products (Tables 4 and 5). This may be due to the differential effect on protein setting associated with time. Increased cooked ash content corresponded to increased salt content in smoked products. 


\section{CONCLUSIONS}

Brine concentration and brining time affect protein-protein and proteinwater interactions that, in turn, affect processing yields, texture development and water-phase salt content of smoked fillets.

Increasing brine concentration increased fillet weight loss after brining, cook yield, water-phase salt content, shear force, brined fat, brined and cooked ash and decreased water activity, brined $\mathrm{pH}$, brined and cooked moisture. Brining time linearly increased myofibrillar protein solubility, fillet weight loss after brining, total and water-phase salt content, and cooked ash content and linearly decreased water activity, brined and cooked moisture content. A quadratic relationship existed between brining time and shear force, with a maximum force at $90 \mathrm{~min}$. At $8.7 \%$ brine, quadratic relationships were observed between hardness and cohesiveness, and brining time with maximum hardness and cohesiveness at $90 \mathrm{~min}$. According to texture and water-phase salt data, an $8.7 \%$ brine concentration and a $90-\mathrm{min}$ brining time is the appropriate combination for texture development and for addressing water-phase salt content required by the Food and Drug Administration regulation ( $\leq 3.5 \%)$. However, this brine concentration and brining time combination may vary depending on the quality and size of the raw material, and the brining protocol, especially brining time, should be adjusted accordingly. 


\section{REFERENCES}

Acton,J.C. and Dick,R.L. 1984. Protein-protein interaction in processed meats. In: Proceeding of the $37^{\text {th }}$ Annual Reciprocal Meat Conference. Chicago:National Livestock and Meat Board. p. 36-43.

Anonymous. 1963. Botulism. Morbid. Mortal. Weekly Rep. 12: 337-339.

AOAC. 1990. Official Methods of Analysis. $15^{\text {th }}$ ed. Washington, DC.:Association of Official Analytical Chemists.

Astawan,M., Wahyuni,M., Yamada,K., Tadokoro,T., and Maekawa,A. 1994. Effect of high salt content of Indonesian dried-salted fish on rats. J. Agric. Food Chem. 42(10): 2265-2269.

Bligh,E.G. and Duclos-Rendell,R. 1986. Chemical and physical characteristics of lightly salted minced cod (Gadus morhua). J. Food Sci. 51(1): 76-78.

Bourne,M.C. 1978. Texture profile analysis. Food Technology. 32(7): 62-66, 72.

Center for Disease Control. 1979. Botulism in the United States, 1899-1977. In: Handbook for Epidermiologists, Clinicians and Laboratory Workers.

Atlanta:Center for Disease Control. p. 25.

Cheftel,J.C., Cuq,J.L., and Lorient,D. 1985. Amino acids, peptides, and proteins. In: O.Fennema, editor. Food Chemistry. New York:Marcel Dekker Inc. p. 245.

Christiansen,L., Deffner,J., Foster,E., and Sugiyama,H. 1968. Survival and outgrowth of Clostridium botulinum Type E spores in smoked fish. Appl. Microbiol. 16(1): 133-137.

Dunajski,E. 1979. Texture of fish muscle. J. Texture Studies. 10(4): 301-317.

Economic Research Service. 2000. Aquaculture outlook. March 13. U.S. Department of Agriculture. LDP-AQS-11.

Federal Register. 1995. Procedures for the safe and sanitary processing and inporting of fish and fishery products. Federal Register. 60(242): 65161-65163.

Foegeding,E.A., Lanier,T.C., and Hultin,H.O. 1996. Characteristics of edible muscle tissues. In: O.Fennema, editor. Food Chemistry. New York:Marcel Dekker, Inc. p. 915.

Food and Drug Administration. 1997. Food and Drug Administration Compliance Program Guidance Munnual. 17 January, section 7303.842.

Greaser,M.L., Yates,L.D., Krzywicki,K., and Roelke,D.L. 1983. Electrophoretic methods for the separation and identification of muscle proteins. In: Proceeding 
of the $36^{\text {th }}$ Annual Recip. Meat Conf. Chicago:National Livestock and Meat Board. p. 87.

Gornall,A.G., Bardawill,C.T., and David,M.M. 1949. Determination of serum proteins by means of the biuret reaction. J. Biol. Chem. 177(2): 751-766.

Hamm,R. 1960. Biochemistry of meat hydration. Adv. Food Res. 10: 355-463.

Hastings,R.J., Rodger,G.W., Park,R., Matthews,A.D., and Anderson,E.M. 1985. Differential scanning calorimetry of fish muscle: The effect of processing and species variation. J. Food Sci. 50(2): 503-506, 510.

Hatae,K., Yoshimatsu,F., and Matsumoto,J.J. 1990. Role of muscle fibers in contributing firmness of cooked fish. J. Food Sci. 55(3): 693-696.

Heinitz,M.L. and Johnson,J.M. 1998. The incidence of Listeria spp., Salmonella spp., and Clostridium botulinum in smoked fish and shellfish. J. Food Prot. 61(3): 318-323.

Heinitz,M.L., Ruble,R.D., Wagner,D.E., and Tatini,S.R. 2000. Incidence of Salmonella in fish and seafood. J. Food Prot. 63(5): 579-592.

Hermansson,A.M. 1978. Physico-chemical aspects of soy proteins structure formation. J. Texture Studies. 9(1/2): 33-58.

Hultin,H.O., Stanley,D.W., and Feng,Y. 1995. A re-examination of muscle protein solubility. J. Muscle Foods 6(2): 91-107.

Lautenschlager,R. 1985. Diffusion of sodium chloride and sodium nitrite in raw meat model systems. In: Proceeding of the $41^{\text {st }}$ Int.Cong.Meat Sci.Tech. Vol. 2. San Antanio. p. 507-508.

National Agricultural Statistics Service. 2000. Trout production. U.S. Department of Agriculture. www.usda.gov/nass.

Nayak,R., Kenney,P.B., and Slider,S. 1996. Protein extractability of turkey breast and thigh muscle with varying sodium chloride solutions as affected by calcium, magnesium and zinc chloride. J. Food Sci. 61(6): 1149-1154.

Nketsia-Tabiri,J. and Sefa-Dedeh,S. 1995. Optimization of process, conditions and quality of salted dried tilapia (Oreochromis miloticus) using response surface methodology. J. Sci. Food Agric. 69(1): 117-127.

SAS Institute Inc. SAS users guide: Basics version 6.06. Statistical Analysis System Institute Inc. Cary, NC.

Siegel,D.G. and Schmidt,G.R. 1979. Ionic, pH and temperature effects on the binding ability of myosin. J. Food Sci. 44 (6): 1686-1689. 
Stone,A.P. and Stanley,D.W. 1992. Mechanisms of fish muscle gelation. Food Res. Int. 25(5): 381-388.

Takahashi,T. 1960. Shajuku gyokainiku ni tsuite no shogensho. New Food Ind. 2: 38.

Whitney,E.N. and Rolfes,S.R. 1996. Water and the major minerals. In: E.N. Whitney and S.R. Rolfes, editors. Understanding Nutrition. St. Paul:West Publishing Company. p. 441. 
Table 1. Brined $\mathrm{pH}$, cooked $\mathrm{pH}$, and total protein and actin solubility at various brine concentrations or brining times.

\begin{tabular}{l|cc||cccc|c}
\hline \multirow{2}{*}{ Response } & \multicolumn{3}{|l|}{ Brine concentration, \% (w/v) } & \multicolumn{3}{|c|}{ Brining time, min } & \multirow{2}{*}{ Orthogonal } \\
\cline { 2 - 6 } & 8.7 & 17.4 & 30 & 60 & 90 & 120 & comparison \\
\hline Brined pH & $6.42^{\mathrm{b}}$ & $6.37^{\mathrm{a}}$ & 6.39 & 6.38 & 6.40 & 6.40 & - \\
Cooked pH & $6.56^{\mathrm{a}}$ & $6.55^{\mathrm{a}}$ & 6.56 & 6.56 & 6.54 & 6.56 & - \\
Total protein solubility, $\mathrm{mg} / \mathrm{mL}$ & $10.21^{\mathrm{a}}$ & $9.36^{\mathrm{a}}$ & 10.12 & 10.12 & 9.55 & 9.35 & - \\
Actin solubility, $\mu \mathrm{g} / \mathrm{mL}$ & $25.41^{\mathrm{a}}$ & $30.63^{\mathrm{b}}$ & 26.49 & 28.09 & 27.67 & 29.84 & $\mathrm{~L}$ \\
\hline
\end{tabular}

${ }^{a b}$ Means within each response with different superscripts are different $(p<0.05)$.

${ }^{*} \mathrm{~L}$ : Linear relationship between brining time and response $(-3-1+1+3 ; p<0.05)$.

-: Brining time did not affect response $(p>0.05)$. 
Table 2. Estimated ionic strength in brined and cooked fillets at various brine concentrations or/and brining times.

\begin{tabular}{l|cc|cccc}
\hline & \multicolumn{3}{|c|}{ Brine concentration, \% (w/v) } & \multicolumn{4}{|c}{ Brining time, min } \\
\cline { 2 - 6 } & 8.7 & 17.4 & 30 & 60 & 90 & 120 \\
\cline { 2 - 6 } Brined & 0.41 & 0.70 & 0.41 & 0.50 & 0.57 & 0.70 \\
Cooked & 0.79 & 1.25 & 0.82 & 0.92 & 1.06 & 1.29 \\
\hline
\end{tabular}

\begin{tabular}{l|cccc|cccc}
\hline & \multicolumn{3}{|c|}{$8.7 \%(\mathrm{w} / \mathrm{v})$ Brine concentration } & \multicolumn{4}{c}{$17.4 \%(\mathrm{w} / \mathrm{v})$ Brine concentration } \\
\cline { 2 - 9 } & \multicolumn{4}{|c|}{ Brining time, min } & \multicolumn{4}{c}{ Brining time, min } \\
\cline { 2 - 9 } Brined & 30 & 60 & 90 & 120 & 30 & 60 & 90 & 120 \\
\cline { 2 - 9 } Cooked & 0.33 & 0.38 & 0.43 & 0.50 & 0.55 & 0.63 & 0.72 & 0.90 \\
\hline
\end{tabular}


Table 3. Brine uptake, fillet cook yield, water-phase salt content, water activity, and fillet shear force at various brine concentrations or brining times.

\begin{tabular}{|c|c|c|c|c|c|c|c|}
\hline \multirow{2}{*}{ Response } & \multicolumn{2}{|c|}{ Brine concentration, $\%(w / v)$} & \multicolumn{4}{|c|}{ Brining time, $\min$} & \multirow{2}{*}{$\begin{array}{l}\text { Orthogonal } \\
\text { comparison* }\end{array}$} \\
\hline & 8.7 & 17.4 & 30 & 60 & 90 & 120 & \\
\hline Brine uptake, \% & $1.09^{b}$ & $-1.50^{a}$ & 0.15 & -0.04 & -0.18 & -0.76 & $L$ \\
\hline Fillet cook yield, \% & $63.78^{a}$ & $66.39^{b}$ & 64.98 & 65.44 & 64.93 & 64.99 & - \\
\hline Water-phase salt content, \% & $4.65^{\mathrm{a}}$ & $7.33^{b}$ & 4.79 & 5.40 & 6.23 & 7.53 & $L$ \\
\hline Water activity & $0.97^{b}$ & $0.95^{a}$ & 0.96 & 0.96 & 0.95 & 0.95 & $\mathrm{~L}$ \\
\hline Fillet shear force, $\mathrm{g}$ & $671^{a}$ & $784^{b}$ & 657 & 719 & 786 & 747 & Q \\
\hline
\end{tabular}

${ }^{a b}$ Means within each response with different superscripts are different $(p<0.05)$.

${ }^{*} L$ : Linear relationship between brining time and response $(-3-1+1+3 ; p<0.05)$.

$Q:$ Quadratic relationship between brining time and response $(+1-1-1+1 ; p<0.05)$.

-: Brining time did not affect response ( $p>0.05)$. 
Table 4. Proximate composition of brined fillets at various brine concentrations or brining times.

\begin{tabular}{|c|c|c|c|c|c|c|c|}
\hline \multirow{2}{*}{ Composition, \% } & \multicolumn{2}{|c|}{ Brine concentration, $\%(w / v)$} & \multicolumn{4}{|c|}{ Brining time, min } & \multirow{2}{*}{$\begin{array}{l}\text { Orthogonal } \\
\text { comparison* }\end{array}$} \\
\hline & 8.7 & 17.4 & 30 & 60 & 90 & 120 & \\
\hline Moisture & $75.99^{b}$ & $73.81^{a}$ & 79.55 & 75.51 & 74.94 & 73.60 & L \\
\hline Fat & $1.05^{a}$ & $1.90^{b}$ & 1.24 & 0.97 & 1.69 & 2.01 & - \\
\hline Protein & $17.57^{\mathrm{a}}$ & $17.79^{a}$ & 17.75 & 17.65 & 17.72 & 17.61 & - \\
\hline Ash & $2.38^{a}$ & $3.01^{b}$ & 2.58 & 2.74 & 2.77 & 2.69 & - \\
\hline
\end{tabular}

${ }^{\mathrm{ab}}$ Means within each response with different superscripts are different $(\mathrm{p}<0.05)$.

${ }^{*} \mathrm{~L}$ : Linear relationship between brining time and response $(-3-1+1+3 ; p<0.05)$.

-: Brining time did not affect response ( $p>0.05)$. 
Table 5. Proximate composition of smoked fillets at various brine concentrations or brining times.

\begin{tabular}{|c|c|c|c|c|c|c|c|}
\hline \multirow{2}{*}{ Composition, \% } & \multicolumn{2}{|c|}{ Brine concentration, \% (w/v) } & \multicolumn{4}{|c|}{ Brining time, $\min$} & \multirow{2}{*}{$\begin{array}{l}\text { Orthogonal } \\
\text { comparison }\end{array}$} \\
\hline & 8.7 & 17.4 & 30 & 60 & 90 & 120 & \\
\hline Moisture & $60.73^{b}$ & $59.16^{\mathrm{a}}$ & 60.40 & 60.81 & 59.79 & 58.79 & $L$ \\
\hline Fat & $6.51^{a}$ & $6.00^{a}$ & 6.35 & 5.96 & 6.01 & 6.71 & - \\
\hline Protein & $27.42^{a}$ & $27.49^{a}$ & 27.72 & 27.47 & 27.72 & 26.89 & - \\
\hline Ash & $4.11^{\mathrm{a}}$ & $5.46^{b}$ & 4.29 & 4.46 & 4.91 & 5.49 & L \\
\hline
\end{tabular}

${ }^{\mathrm{ab}}$ Means within each response with different superscripts are different $(\mathrm{p}<0.05)$.

${ }^{*} \mathrm{~L}$ : Linear relationship between brining time and response $(-3-1+1+3 ; p<0.05)$.

-: Brining time did not affect response ( $p>0.05)$. 


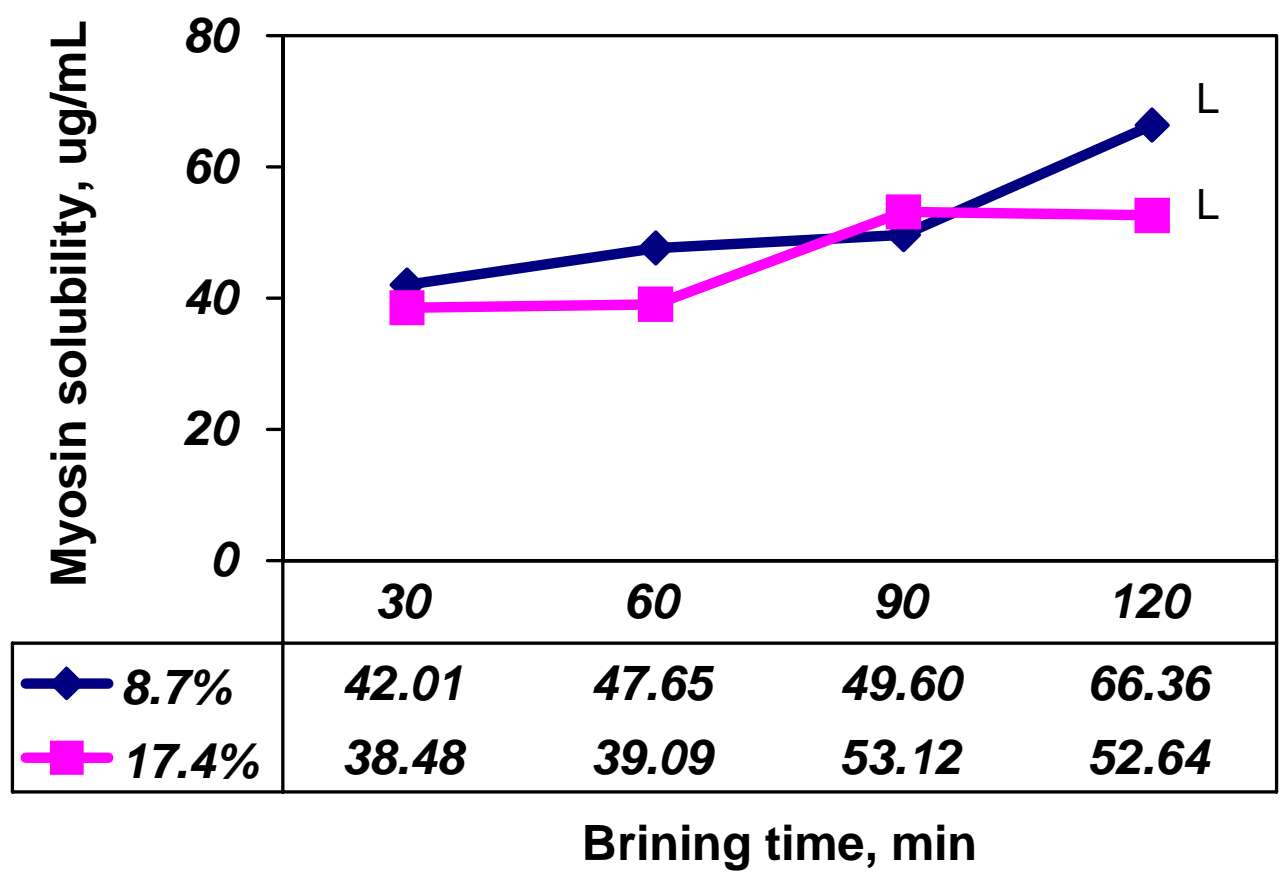

Figure 1. Myosin solubility patterns for 8.7 and $17.4 \%(\mathrm{w} / \mathrm{v})$ brine at different brining times.

L: Linear relationship between brining time and myosin solubility $(-3-1+1+3$; $p<0.05)$. 


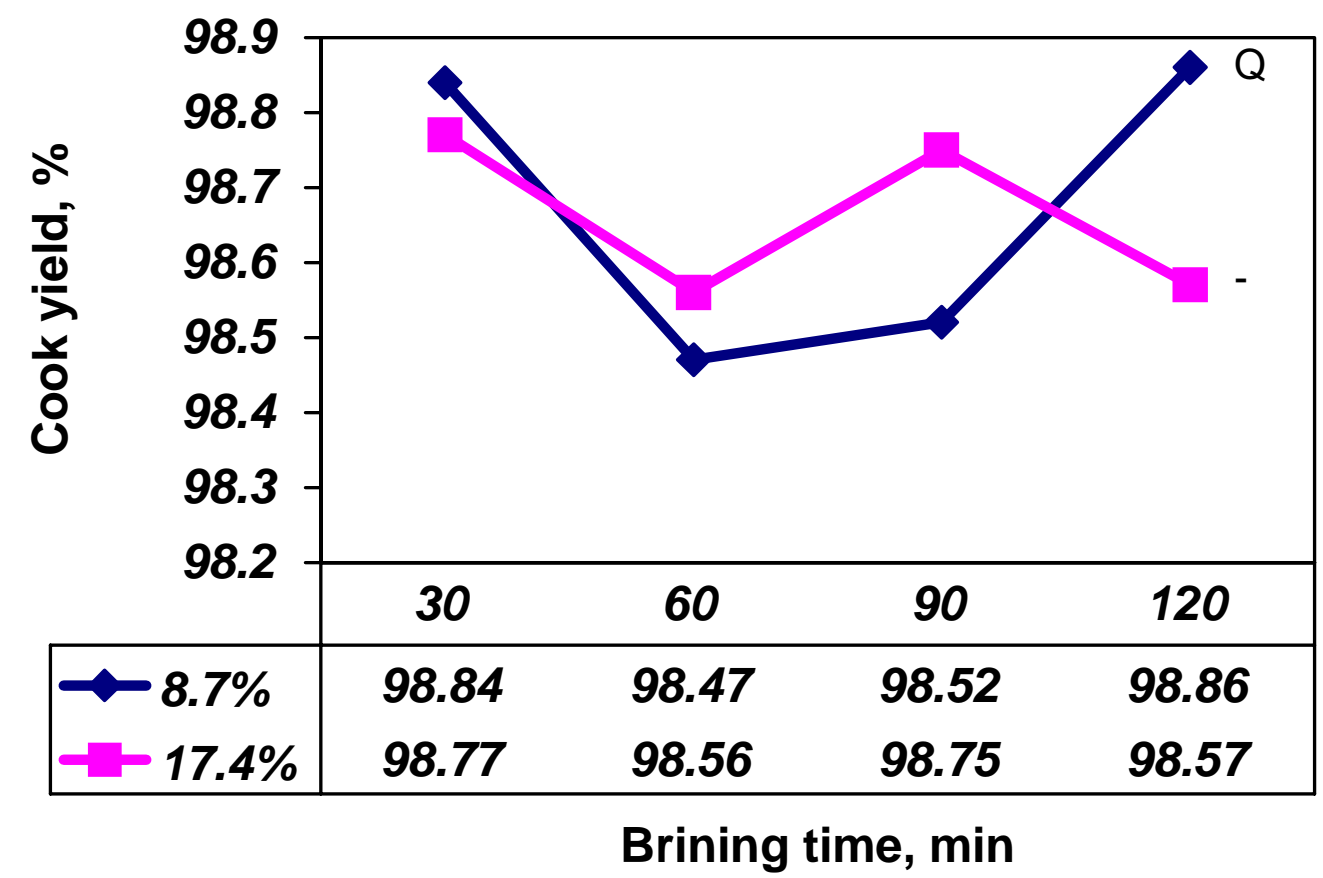

Figure 2. Mince cook yield patterns for 8.7 and $17.4 \%(w / v)$ brine at different brining times.

Q: Quadratic relationship between brining time and cook yield $(+1-1-1+1$; $\mathrm{p}<0.05)$

-: Brining time did not affect cook yield ( $p>0.05)$. 


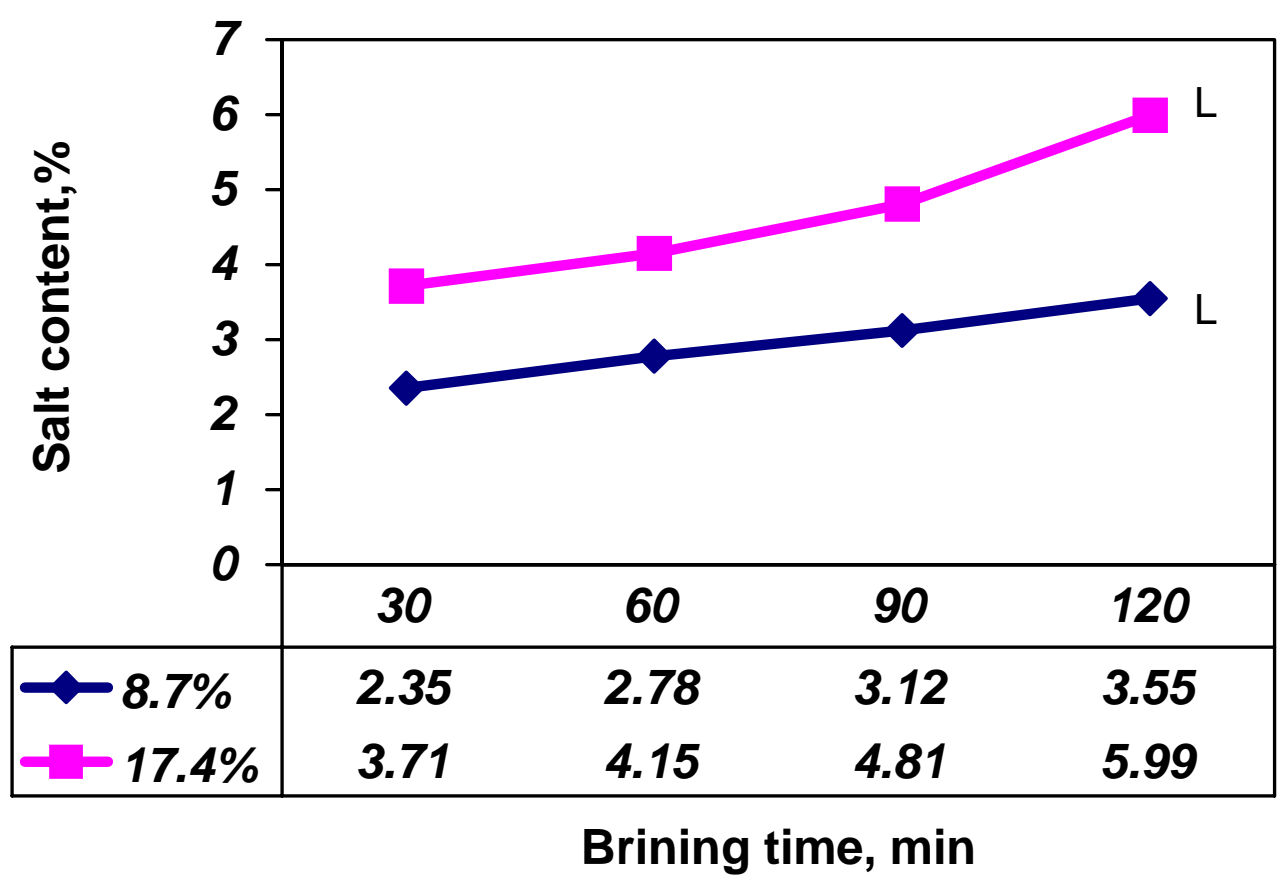

Figure 3. Salt content patterns of smoked fillets for 8.7 and $17.4 \%(w / v)$ brine at different brining times.

L: Linear relationship between brining time and salt content $(-3-1+1+3$; $p<0.05)$. 


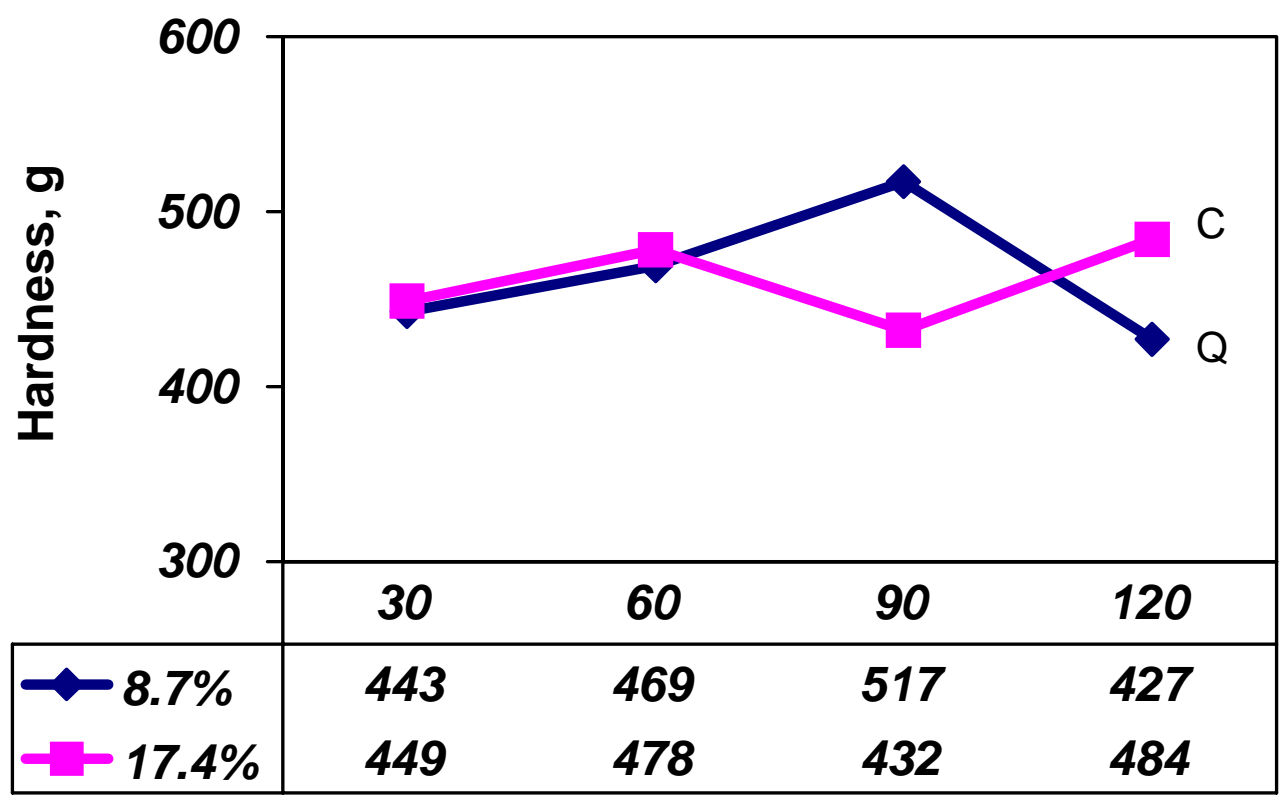

Brining time, min

Figure 4. Hardness patterns of cooked mince for 8.7 and $17.4 \%(w / v)$ brine at different brining times.

Q: Quadratic relationship between brining time and hardness $(+1-1-1+1$; $\mathrm{p}<0.05)$.

C: Cubic relationship between brining time and hardness $(-1+3-3+1$; $p<0.05)$. 


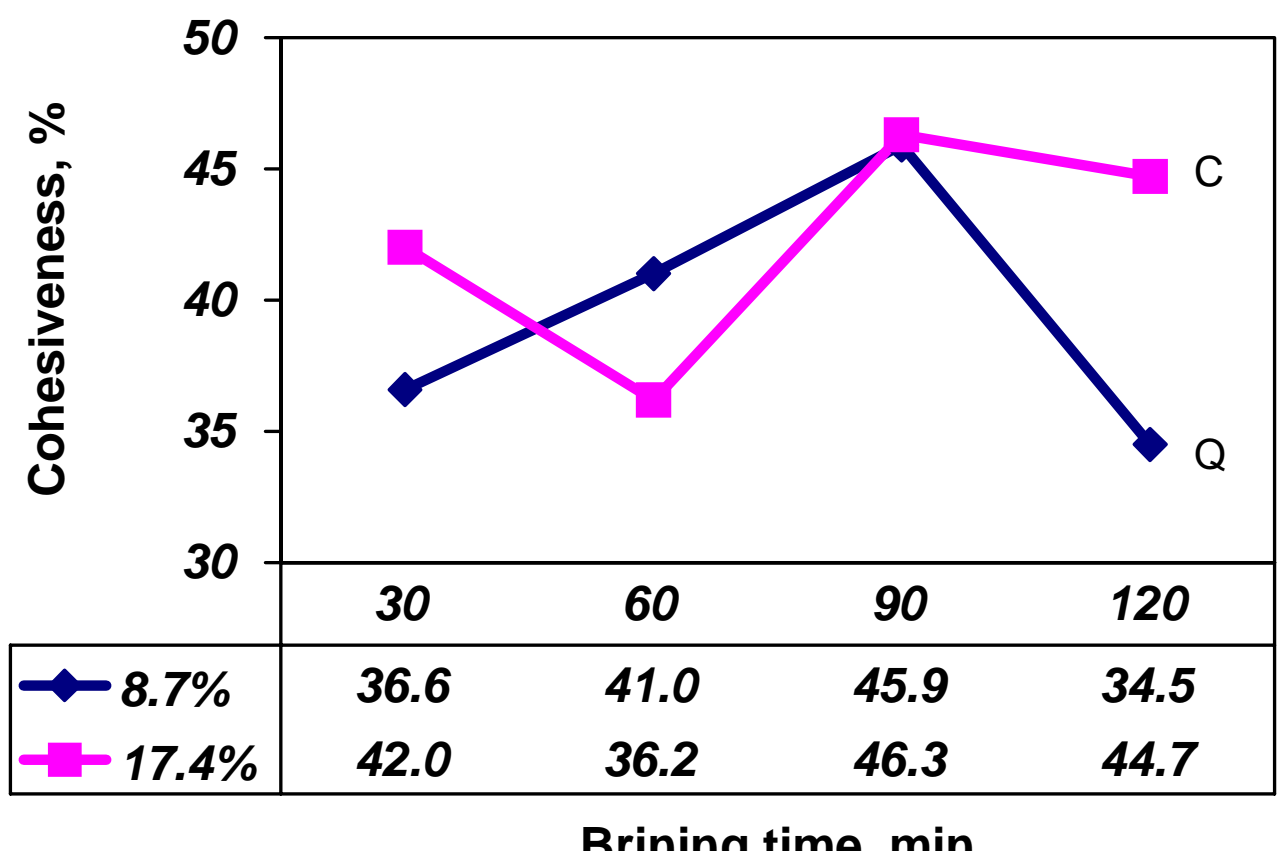

Figure 5. Cohesiveness patterns of cooked mince for 8.7 and $17.4 \%(\mathrm{w} / \mathrm{v})$ brine at different brining times.

Q: Quadratic relationship between brining time and cohesiveness $(+1-1-1+1 ; p<0.05)$.

C: Cubic relationship between brining time and cohesiveness $(-1+3-3+1$; $\mathrm{p}<0.05)$. 
Figure 6. Electrophoretic gel patterns of fish muscle protein for $8.7 \%(\mathrm{w} / \mathrm{v})$ brine at different brining times.

MWS: molecular weight standards

PS: protein standards

M: myosin $5 \mu \mathrm{g}$

A: actin $5 \mu \mathrm{g}$

Figure 7. Electrophoretic gel patterns of fish muscle protein for $17.4 \%(\mathrm{w} / \mathrm{v})$ brine at different brining times.

MWS: molecular weight standards

PS: protein standards

M: myosin $5 \mu \mathrm{g}$

A: actin $5 \mu \mathrm{g}$ 

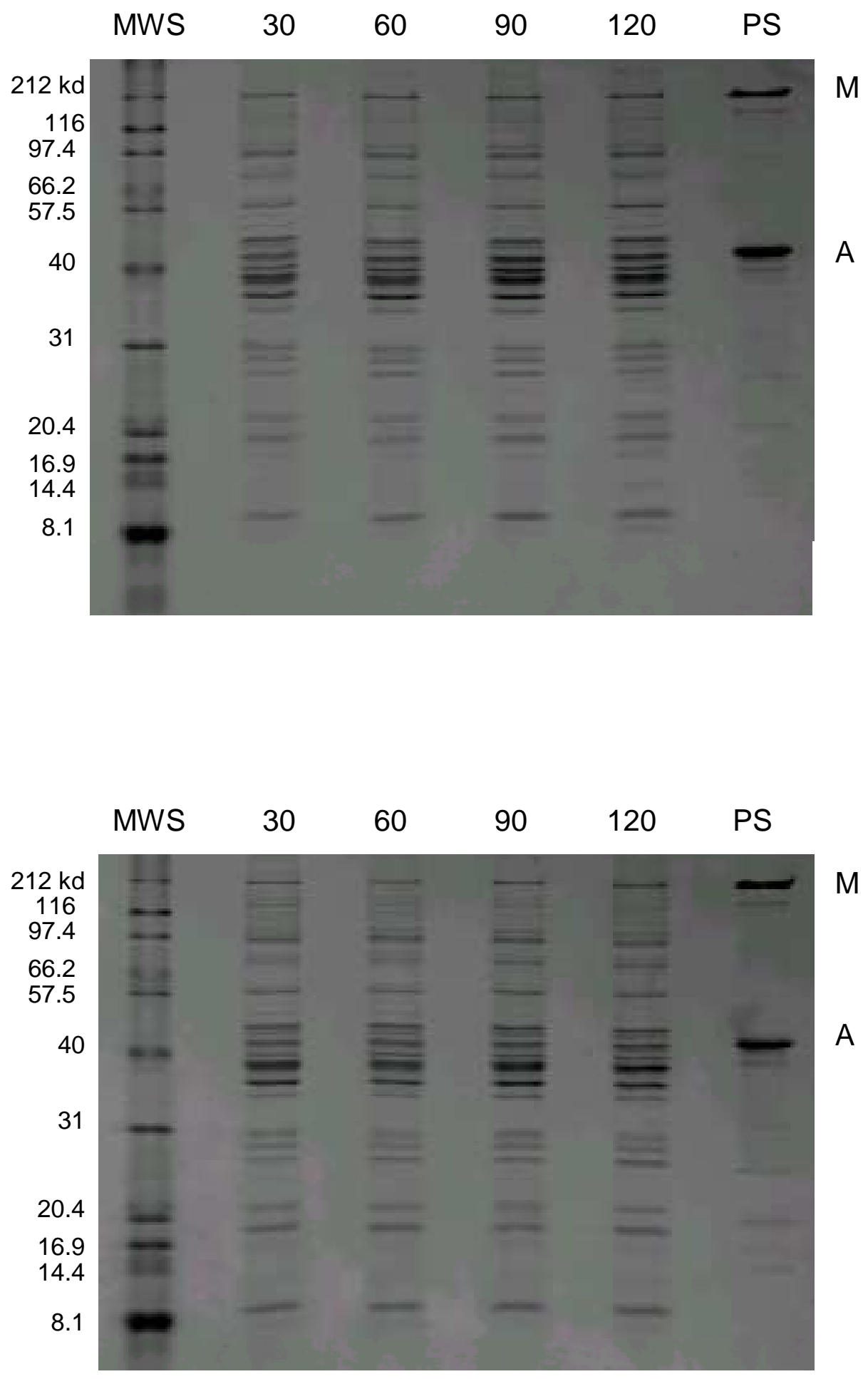


\section{APPENDICES}




\section{APPENDIX 1}

\section{THERMAL PROCESSING SCHEDULE}

\begin{tabular}{ccccccc}
\hline Stage & $\begin{array}{c}\text { Time } \\
\text { h:min }\end{array}$ & $\begin{array}{c}\text { Oven } \\
\text { temp, }{ }^{\circ} \mathrm{C}\end{array}$ & $\begin{array}{c}\text { Core } \\
\text { temp, }{ }^{\circ} \mathrm{C}\end{array}$ & Damper & Blower & Options \\
\hline 1 & $00: 30$ & 32.2 & - & close & high & generate heat \\
2 & $00: 30$ & 43.3 & - & close & high & generate feed \\
3 & $00: 30$ & 54.4 & - & close & high & generate feed \\
4 & $00: 30$ & 65.5 & - & close & high & generate feed \\
5 & - & 71.1 & 65.5 & half & high & generate feed \\
6 & $00: 35$ & 66.7 & - & close & high & generate feed \\
7 & $00: 15$ & - & - & open & off & generate heat \\
\hline
\end{tabular}




\section{APPENDIX 2}

\section{STATISTICAL PROGRAM}

option LS $=80$ pagesize $=60$ nonumber;

title '2X4 FACTORIAL RCB - BRINING PROTOCOL';

data $x x x$; input day conc $\$$ time $\$$ fish $x x x$;

cards;

proc print;

proc glm; classes day conc time fish;

model $x x x=$ day conc|time;

Ismeans conc|time/pdiff;

contrast 'linear' time $-3-1+1+3$;

contrast 'quadratic' time $+1-1-1+1$;

contrast 'cubic' time $-1+3-3+1$;

run; 


\section{CHAPTER 2}

\section{EFFECT OF HANDLING STRESS ON MUSCLE QUALITY OF SMOKED ARCTIC CHARR, Salvelinus alpinus, FILLETS}




\section{ABSTRACTS}

Effects of animal handling on muscle physiology in the late ante-mortem period influence post-mortem biochemical changes in fish muscle. Minimizing stress during handling will decrease rate and extent of muscle metabolism that, in turn, affects quality of raw and smoked fillets. Arctic charr, Salvelinus alpinus, hatched at 6.5 and $9.5^{\circ} \mathrm{C}$ and from large, medium, and small size groups were assigned to: 1) processing with no stress; 2) processing immediately after stress; 3) processing $24 \mathrm{~h}$ after stress; and 4) processing $48 \mathrm{~h}$ after stress. Fish were quickly removed from the water for the no-stress control. Handling stress was mimicked by crowding fish in a net in shallow water for 5 min. A $2 \times 3 \times 4$ factorial, split-plot experimental design was employed. After removal from the water, fish were mechanically stunned. Fork length and whole body, gonad, gut, head, frame, and fillet weights were recorded. Muscle $L^{*}, a^{*}$, and $b^{*}$ values were measured before freezing the fillets for 3 wk at $-20^{\circ} \mathrm{C}$. Brine uptake, brined $\mathrm{pH}$, cook yield, cooked color, total and water-phase salt content, shear force and proximate composition of smoked fillets were evaluated. Stress reduced gut weight and muscle $\mathrm{a}^{*}$ value, increased muscle $\mathrm{L}^{*}$ for the $9.5^{\circ} \mathrm{C}$ group, decreased muscle $L^{*}$ for the $6.5^{\circ} \mathrm{C}$ group, and increased fillet weight loss after brining. Fish hatched at $9.5^{\circ} \mathrm{C}$ appeared to be more sensitive to handling stress than fish hatched at $6.5^{\circ} \mathrm{C}$; fillets from the stressed, $9.5^{\circ} \mathrm{C}$ group absorbed more brine, increasing salt and ash content of smoked products. Resting for $24 \mathrm{~h}$ after stress decreased total and water-phase salt, and ash content. Resting for $48 \mathrm{~h}$ increased gut weight and enhanced muscle $L^{*}$. However, muscle $a^{*}$ was not 
recovered after a 48-h resting period. Muscle from the small size group had a lower $L^{*}$ value compared to the large and medium size groups. Smoked fillets produced from the small size category had a higher protein and fat content, and a lower moisture content compared to the large size category.

Keywords: Arctic charr, handling stress, muscle quality, smoked fish. 


\section{INTRODUCTION}

Stress resulting from animal handling in the late ante-mortem period affects rate and extent of muscle metabolism in the early post-mortem period and thereby affects muscle quality. Rate of onset and resolution of rigor mortis influence appearance and structure of fish muscle, thus impacting muscle quality (Stroud, 1968; Nakayama et al., 1994). When fish are killed while relaxed, creatine phosphate is degraded prior to destruction of adenosine triphosphate (ATP) (Iwamoto et al., 1988). The ATP content begins decreasing when creatine phosphate level reaches about the same concentration as ATP. The muscle enters full rigor mortis when ATP decreases to about $1 \mu \mathrm{mol} / \mathrm{g}$. Rigor occurs when crossbridge cycling between myosin and actin stops, and permanent myosin and actin lingkages are formed (Pate and Brokaw, 1980).

The requirement for high flesh quality in raw products for commercial markets has stimulated many studies of the effects of stress physiology on postmortem biochemical changes in muscle of a variety of fish species. In general, handling stress led to lower muscle creatine phosphate, ATP, and $\mathrm{pH}$; a faster

onset of rigor mortis (Berg et al., 1997; Sigholt et al., 1997); higher plasma cortisol, muscle lactate (Lowe et al., 1993), and K-value (Erikson et al., 1997); and softer muscle texture (Jerrett et al., 1996; Erikson et al., 1997; Sigholt et al., 1997). Unlike meat, post-mortem "tenderization" or autolysis of fish muscle is highly undesirable to processors and consumers (Tsuchiya et al., 1992). Choosing the most suitable method for ante-mortem handling prior to slaughter is an important step in assuring good quality of cultured fish. 
Arctic charr, Salvelinus alpinus, is recognized as an experimental species for aquaculture in the Northeastern region of the United States (Northeastern Regional Aquaculture Center, 1997). Handling effects, immediately prior to and during harvest, on the quality of Arctic charr muscle are not well defined. Therefore, the objectives of this experiment were to 1) evaluate effects of antemortem handling stress on muscle quality and composition of smoked fillets and 2) determine the effect of resting period after stress on recovery of muscle quality attributes.

The experiment was also conducted to determine the association of hatching temperature with biological characteristics of the fish and quality of fresh and smoked fillets.

\section{MATERIALS AND METHODS}

\section{Fish background and experiment}

In December 1996, Arctic Charr eggs (Labrador strain) were incubated and hatched at 6.5 or $9.5^{\circ} \mathrm{C}$ in dark incubators supplied with recirculating pathogen-free spring water. The water temperature was controlled within $\pm 0.5^{\circ} \mathrm{C}$. The insulated, recirculating incubation system included a $\mathrm{CO}_{2}$ stripper, water reservoir, pump, chiller, ultraviolet disinfection unit, and make-up water input. Incubation density was 776 eggs/L.

After hatching, fry were initially held in recirculating system conditions that included the aforementioned components (excluding incubator trays) and bag and bead filters for solid removal. Fry were transferred to a flow-through condition when the make-up water dilution was insufficient to keep unionized 
ammonia below $0.01 \mathrm{ppm}$. Fry were reared in $1.22 \mathrm{~m}$ diameter $\times 0.30 \mathrm{~m}$ deep tanks operated at a $0.12-0.15 \mathrm{~m}$ water depth. Flow orientation was adjusted to provide low rotational velocities during the first feeding. Tanks were kept covered until fry were actively swimming and feeding. When the covers were removed, fish were exposed to ambient photoperiod. Feeding of fry began the day after transfer of incubators to tanks. Throughout the study, fish were fed a salmon diet (Bio-Oregon, Inc; Warrenton, OR and Moore Clark USA; Bellingham, WA) based on the standard diet recommendations for feed size. When fish were free swimming and feeding, approximately 3-m post-hatch, culture temperature was increased to ambient temperature $\left(11.5-12.5^{\circ} \mathrm{C}\right)$. Fish were reared at this temperature until the end of the experiment (approximately 2 years).

In the summer of 1997, each of the two hatching temperature groups was split into large, medium, and small sizes using bar graders (Appendix 1). Although there were different numbers of fish in each tank, density was standardized to $50 \mathrm{~kg} / \mathrm{m}^{3}$. Fish were fed Trout Grower (42\% protein, $15 \%$ fat; Ziegler Bros, Inc.; Gardners, PA) with demand feeders. Two hatching temperatures and three size categories resulted in six groups of fish.

In February 1999, fish of each group were randomly assigned to four antemortem handling stress treatments: 1) processing with no stress (no-stress control); 2) processing immediately after stress (stress without rest); 3) processing $24 \mathrm{~h}$ after stress (stress $+24-\mathrm{h}$ rest); and 4 ) processing $48 \mathrm{~h}$ after stress (stress $+48-\mathrm{h}$ rest). Fish were fasted $48 \mathrm{~h}$ before handling stress was applied. Crowding fish in a net in shallow water for 5 min was used to mimic 
handling stress. Following stress and without feeding, fish were held in recovering tanks for 24 and $48 \mathrm{~h}$ prior to removal. For the no-stress control, fish were removed immediately from the water and for the stress-without-rest treatment, fish were collected immediately following stress.

After removal from the water, fish were mechanically stunned. Whole body weight and fork length were measured. Fish were immediately eviscerated and filleted. Gut, gonad, head, frame, and fillet weights and gender were recorded. Following filleting, the "fillet" is described as a butterfly fillet. Individual fillets were packed in Ziploc ${ }^{\circledR}$ bags, stored on ice, and transported to the processing laboratory. Fish were individually vacuum packed (Ultravac ${ }^{\circledR}$, Model UV500, Koch; Kansas City, MO) and stored for 3 wk at $-20^{\circ} \mathrm{C}$. Time elapsed between removal from the tank until freezing was approximately $8 \mathrm{~h}$.

\section{Fillet processing}

Fillets were thawed at $3^{\circ} \mathrm{C}$ overnight and subsequently soaked in $8.7 \%$ $(\mathrm{w} / \mathrm{v})$ sodium chloride solution for $90 \mathrm{~min}$ at $3^{\circ} \mathrm{C}$. Light brown sugar was added at $69 \%(\mathrm{w} / \mathrm{w})$ of the sodium chloride required for the brine. A fillet to brine ratio of 1 fillet (475-g average weight) to $1.4 \mathrm{~L}$ of brine was used. Following brining, fillets were drained and placed on stainless steel expanded metal racks with skin down for $24 \mathrm{~h}$ at $3^{\circ} \mathrm{C}$. This time was chosen to allow brine equilibration and pellicle formation. Fillets were covered with polyethylene wrap $4 \mathrm{~h}$ after draining to prevent excessive drying.

Brined fillets were thermally processed in a microprocessor-controlled smokeoven (Enviro-Pak, Model CVU-490; Clackamas, OR) to an internal 
temperature of $65.5^{\circ} \mathrm{C}$ and held for $50 \mathrm{~min}$. This heating process met the minimum requirement of the FDA Fish and Fishery Products Hazards and Controls Guide, 21 CFR 123 (Federal Register, 1995). After cooking, smoked fillets were cooled at ambient temperature for $30 \mathrm{~min}$, at $3^{\circ} \mathrm{C}$ for an additional 30 min, and packed in polyethylene bags. Samples were aerobically stored at $3^{\circ} \mathrm{C}$, and analyses were carried out within $24 \mathrm{~h}$. Cooked fillets were used for measurement of color, shear force, total and water-phase salt content, $\mathrm{pH}$, and proximate composition.

\section{Sample preparation}

One side of smoked fillet was randomly selected, and a $2.54 \times 10 \mathrm{~cm}$ piece of the dorsal musculature was used for fillet texture analyses. Dunajski (1979) indicated that the body composition of cultured rainbow trout, Oncorhychus mykiss, did not differ between left and right sides. Immediately following this measurement, the sheared fillet was collected in a whirl-pak ${ }^{\circledR}$ bag for determination of total and water-phase salt.

The remaining half of the smoked fillet was skinned, cut into small pieces, and chopped in a Cuisinart ${ }^{\circledR}$ food processor for $45 \mathrm{~s}$. Samples were stored at $-20^{\circ} \mathrm{C}$ until proximate composition was determined.

\section{Chemical and physical analysis}

Color measurement: Surface color measurements of fresh and smoked fillets were recorded with a chromameter (Minolta, Model CR-300, Minolta Camera Co. Ltd.; Osaka, Japan). The instrument was color calibrated using a standard white plate No.21333180 (CIE L* 93.1; $\left.a^{*} 0.3135 ; b^{*} 0.3198\right)$, and $L^{*}$ 
(lightness), $a^{*}$ (redness), and $b^{*}$ (yellowness) values were recorded from readings at four positions (right and left cranial half and right and left caudal half). These values were averaged and used as the observation for that fillet.

pH: Sample pH was measured using a pH/ion analyzer 350 (Corning Inc.; Corning, NY) equipped with a general combination probe. The $\mathrm{pH}$ was measured on brined fillets at the cranial, middle, and caudal areas above the lateral line. These values were averaged and used as the observation for that fillet.

Brine uptake and cook yield: Individual fillets were weighed before brining, after brining, and after cooking. Brine uptake was calculated as the difference between the before and after brining weights. Brined and cooked weights were expressed as a percent of the weight before brining.

Shear force: Shear force was measured with a Warner-Bratzler shear attachment using an Instron Universal Testing Machine (Model TM, Instron Corp.; Canton, MA). Each piece was skinned and placed beneath the blade with the pellicle side down. Each piece was sheared at $2.54 \mathrm{~cm}$ intervals, along the length of a $10-\mathrm{cm}$ strip at $127 \mathrm{~mm} / \mathrm{min}$. Output signal was sent to a computer equipped with a DT 2805 data acquisition board (Data Translation Inc.; Malboro, MA) via a Daytronics mainframe equipped with a LVDT conditioner (Model 9130, Daytronic; Miamisburg, $\mathrm{OH}$ ). These values were averaged and used as the observation for that fillet.

Total and water-phase salt content: Salt content of cooked fish was determined by the Indicating Strip Method (No. 971.19; AOAC, 1990). This 
method uses the Quantab ${ }^{\circledR}$ chloride titrator (Environmental Test Systems, Inc.; Elkhart, IN), No.711196, and it has a range of 0.05 to $1.0 \%$ sodium chloride. After 9:1 dilution, the effective sodium chloride range for the product is 0.5 to $10 \%$. Ten grams of chopped, cooked sample were mixed with $90 \mathrm{~mL}$ of hot water. The slurry was filtered through Whatman No. 41 filter paper, and sodium chloride content was calculated by multiplying the strip reading for sodium by 10 . Moisture content was determined by drying a 3-g of sample collected from the shear test at $103 \pm 1^{\circ} \mathrm{C}$ for $24 \mathrm{~h}$. Percent water-phase salt was calculated as ( $\mathrm{g}$ sodium chloride $\times 100) /($ g sodium chloride $+g$ moisture) (Heinitz and Johnson, 1998).

Proximate composition: Proximate composition was determined using AOAC (1990) approved procedures.

\section{Experimental design}

Responses prior to thermal processing: A $2 \times 3 \times 4$ factorial, split-plot design was used with hatching temperature $\left(6.5\right.$ and $\left.9.5^{\circ} \mathrm{C}\right)$ and fish size categories (large, medium, and small) as main plot variables. Each temperature by size combination was replicated two times in separate tanks of twenty fish except that the small size group, hatched at $9.5^{\circ} \mathrm{C}$, was replicated only one time using forty fish (Appendix 2). Four handling stress treatments (processing with no stress, processing immediately after stress, processing $24 \mathrm{~h}$ after stress, and processing $48 \mathrm{~h}$ after stress) were randomly assigned to five fish of each tank (ten fish of the small size group of $9.5^{\circ} \mathrm{C}$ ) with the exception that four fish were processed $48 \mathrm{~h}$ 
after stress in the small size group of $6.5^{\circ} \mathrm{C}$ and in the large size group of $9.5^{\circ} \mathrm{C}$. Total fish processed in this experiment were 238.

Responses following thermal processing: A $2 \times 3 \times 4$ factorial, split-plot randomized complete block design was conducted with day as block. All fillet samples were separated into four groups depending on fillet thickness (1.852.70, 2.71-3.00, 3.01-3.30, and 3.31-4.37 cm; Appendix 3). Each group was processed on a separate day. Twenty-four treatment combinations appeared in each thickness group.

Data were analyzed using the General Linear Model (GLM) procedure of SAS (SAS Institute, Inc. 1989) to determine main and interaction effects. The PDIFF of the Ismeans procedure was used for separating means. The following orthogonal comparisons were performed to evaluate: 1) the difference between the no-stress and all stress treatments $(3-1-1-1), 2)$ a linear relationship

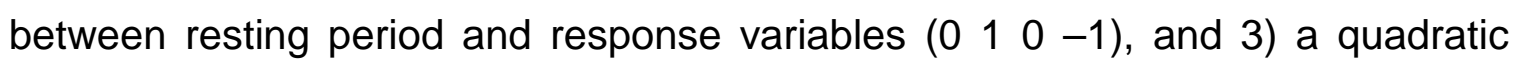
relationship between resting period and response variables $\left(\begin{array}{lll}0 & -1 & 2\end{array}-1\right)$ at a significance level of $p<0.05$.

\section{RESULTS AND DISCUSSION}

\section{Hatching temperature}

Hatching temperature did not affect $(p>0.05)$ fork length, whole body, gut, head and frame weights, and $b^{*}$ value (Table 1). Gonad weights of fish hatched at $6.5^{\circ} \mathrm{C}$ was greater than that of fish hatched at $9.5^{\circ} \mathrm{C}(p<0.10)$. This increased gonad weight was due to difference in the percent of females in each group. 
There were $62 \%$ females in the $6.5^{\circ} \mathrm{C}$ group compared to $42 \%$ females in the 9.5으 group.

After brining, fillets from fish hatched at $6.5^{\circ} \mathrm{C}$ lost less weight $(p<0.05)$ than fillets from fish hatched at $9.5^{\circ} \mathrm{C}$ (Table 1). Fillet surface area influences rate of brine uptake. However, fork length, which would be related to fillet surface area, was not different between hatching temperatures. Possibly incubation and hatching temperature affected early tissue development that manifested itself at harvest as variations in size and metabolism of the muscle. Temperature is known to have a profound influence on organogenesis and rate of development (Jobling et al., 1998). Incubation temperatures may have affected rate of development (Jungwirth and Winkler, 1984; Gillet, 1991; de March, 1995).

\section{Size category}

Fork length and whole body, gut, gonad, head, frame, and fillet weights were not affected $(p>0.05)$ by size category (Table 2$)$. However, the mean of all body characteristics, except gonad weight, slightly decreased but not significantly, from large to small size categories. Even though fish of both hatching temperatures were initially separated into three size groups at approximately $6 \mathrm{~m}$ of age, there was large variation within each size group for both fork length and whole body weight following grow-out at ambient temperature $\left(11.5-12.5^{\circ} \mathrm{C}\right.$; Appendix 4). These numbers overlapped among size groups. Growth rate of charr increases with increasing temperature, reaches a maximum at $12-15^{\circ} \mathrm{C}$, and then declines at higher temperature (Jobling et al., 
1993). Jobling and coworkers (1998) indicated that heterogeneous growth is one of the main problems that has arisen with cultivation of Arctic charr. Heterogeneous growth has frequently been reported when Arctic charr are held in a rearing system under conditions satisfactory for salmonid cultivation. Growth rate is often low and size variation is large when charr are reared in shallowwater tanks (water depth of $30-40 \mathrm{~cm}$ ) at low stocking densities $\left(5-20 \mathrm{~kg} / \mathrm{m}^{3}\right)$. More rapid and homogeneous growth can usually be achieved by holding fish in deeper tanks at higher stocking densities $\left(50-120 \mathrm{~kg} / \mathrm{m}^{3}\right.$ ) (Jobling et al, 1993; Jobling, 1994; de March, 1997). Moreover, farmed charr, especially males, become mature at a young age. Tveiten and coworkers (1996) reported that early maturation among a certain proportion of the males resulted in increased size heterogeneity within the population because differences exist in feeding behavior and growth among mature and immature male fish.

Muscle from the large and medium size categories was darker than that from the small size category (Table $2 ; p<0.05$ ). Muscle $a^{*}$ and $b^{*}$ values were not affected by fish size category ( $p>0.05)$.

Brined $\mathrm{pH}$ gradually decreased as fish size category decreased from large to small (Table 3). There was no difference between brined $\mathrm{pH}$ of medium and either large or small fish ( $p>0.05)$. Ferguson and coworkers (1993) reported white muscle concentrations of ATP, glycogen, and creatine phosphate relative to body size in rainbow trout that ranged in length from 8 to $54 \mathrm{~cm}$. Larger fish possessed a twofold greater concentration of ATP (approximately $7 \mu \mathrm{mol} / \mathrm{g}$ ) than did smaller fish (approximately $3 \mu \mathrm{mol} / \mathrm{g}$ ). Similarly, resting values of muscle 
glycogen ranged from $6 \mu \mathrm{mol} / \mathrm{g}$ in the smallest fish to as high as $15 \mu \mathrm{mol} / \mathrm{g}$ in the largest fish. Resting levels of creatine phosphate, however, were negatively correlated with fish size. Approximately $35 \mu \mathrm{mol} / \mathrm{g}$ of creatine phosphate was found in smaller fish compared to approximately $25 \mu \mathrm{mol} / \mathrm{g}$ in larger species. A greater resting creatine phosphate in smaller fish may be reserved for short-term and fast-acting energy requirements. Watabe and coworkers (1991) characterized the relationship between degradation of creatine phosphate and $\mathrm{pH}$ decline in fast muscle (white muscle) of sardines, Sardinops melanosticta, as follows: 1) creatine phosphate donates its phosphate group to adenosine diphosphate (ADP) to generate ATP, and 2) ATP hydrolysis to ADP produces a proton, thus decreasing intracellular pH. ATP was degraded continuously after the death thereby decreasing muscle $\mathrm{pH}$. However, with creatine phosphate present to regenerate ATP from ADP, ATP concentration remained constant. When creatine phosphate decreased, glycolysis began, and muscle accumulated lactate. From the study of Ferguson and coworkers (1993), larger fish should have a lower ultimate $\mathrm{pH}$ than smaller fish because of higher ATP and glycogen reserves.

Fish size category did not affect $(p>0.05)$ brine uptake, cook yield, total and water-phase salt content of the smoked products (Table 3). However, loss of fillet weight after brining and cook yield increased, although not significantly. This higher cook yield of the small size category may be due to the higher fat content and a greater loss of water than fat during thermal processing. 
Size category did not affect $(p>0.05) L^{*}$ and $a^{*}$ values of smoked products (Table 3). Muscle of fish from the small size group had the lowest $b^{*}$ value before cooking; nonetheless, this difference among the three groups after smoking was not significant. Smoked fillets from the small group had higher b* values than fillets from the large category; whereas, raw muscle $b^{*}$ values of these two categories were not different. Doe (1982) stated that color characteristics of smoked fish depend on skin pigmentation and quantity and composition of the smoke deposits and their interactions with tissue components. Quantity of the smoke deposits may account for the higher $b^{*}$ value of cooked fillets in the small size group. In addition, a greater product fat content for the small size category may be associated with the higher $b^{*}$ value and affinity of smoke deposits for the fillets.

Size catagory did not affect $(p>0.05)$ shear force of smoked fillets (Table 3). Fillets from the small size group had higher shear force values, although not significant, that corresponded to decreased moisture content in cooked products as size category increased from large to small.

Cooked fillets from the large size category had the highest moisture content and the lowest fat and protein content (Table 3). Shearer (1994) concluded that endogenous factors, such as size, sex, and life cycle stage and exogenous factors, such as diet composition, ration level, temperature, and salinity affect proximate composition of cultured fish with emphasis on salmonids. Evidence indicates that protein content of growing salmonids is determined solely by fish size; lipid level is affected by endogenous and exogenous factors; ash 
content is homeostatically controlled; and whole body moisture is inversely related to body lipid. There appears to be no differences in composition between sexes during grow-out. Hatlen and coworkers (1996) reported that changes in composition of Arctic charr fillets were associated with maturation, including an increase in percent water and reductions in the concentrations of protein and lipid. Size category did not affect $(p>0.05)$ fat and ash content of cooked fillets (Table 3).

\section{Ante-mortem handling stress}

This experiment evaluated the effect of handling stress and subsequent recovery from the stress on fillet functionality. Two categories of orthogonal comparisons were conducted to facilitate data interpretation. These are: 1) comparison of the no-stress control to all stress treatments (with and without recovery period), and 2) linear and quadratic relationships for 0,24 , and $48-\mathrm{h}$ resting periods. Linear relationship evaluates whether the effect increases/or decreases linearly as resting period increased from 0 to $48 \mathrm{~h}$; whereas, quadratic relationship evaluates whether the effect is different from 24 to $48 \mathrm{~h}$.

Fork length, and whole body, gonad, head, and frame weights were not affected $(p>0.05)$ by ante-mortem handling stress for all comparisons (Table 4). Handling stress is a short-term effect, while these body characteristics require a long period of time to change. Gut weight was different $(p<0.05)$ between the nostress control and stress treatments, and it increased linearly as resting period

increased from 0 to $48 \mathrm{~h}$. Perhaps stress caused increased diuresis, excretion of waste materials, and mobilization of energy stores. Mazeaud and coworkers 
(1977) indicated increased diuresis when addressing the interrelationship between primary and secondary stress effects in fish. Grafflin (1931) found that undisturbed toad fish, Opsanus tau, and sculpin, Myoxocephalus octodecimospinousus, produced urine at a rate of approximately $4 \mathrm{~mL} / \mathrm{kg} / \mathrm{d}$. Handled or slightly damaged fish produced urine in excess of $30 \mathrm{~mL} / \mathrm{kg} / \mathrm{d}$. Love (1970) reported that, after stress, glycogen broke down within seconds in the muscle and within hours in the liver, and this process was usually followed by a prompt recovery in the liver, although some variation existed. As expected, gut weight gradually increased as fish recovered from the stress. Ante-mortem handling stress did not affect ( $p>0.05)$ muscle $b^{*}$ value (Table 4).

Brine uptake was different $(p<0.05)$ between the control and stressed groups. The no-stress control had the lowest fillet weight loss after brining (Table $4 ; \mathrm{p}<0.05)$. Stress produced softer fillets as evidenced by lower breaking strength in Atlantic salmon, Salmo salar (Sigholt et al., 1997). Jerrett and coworkers (1996) reported that, after 40 -h storage at $2^{\circ} \mathrm{C}$, tensile strength of "rested" king salmon, Oncorhynchus tshawytscha, white muscle was 2.7 times that of the "exhausted" muscle. Hole (1999) also indicated that stress during salmon harvest resulted in a soft flesh. Erikson and coworkers (1997) noted that stressed fish had stronger rigor mortis and softer muscle that was more susceptible to gaping than muscle from unstressed fish. Ando and coworkers (1992) indicated that collagen fibers in stressed fish were more susceptible to disintegration resulting in tenderization of the muscle. Gomez-Guillen and coworkers (2000) found that shear strength of the connective tissue fraction, 
determined by Warner-Bratzler shear was lower in stressed than in non-stressed fish. Wang and coworkers (1998) studied the effect of rigor mortis on equilibrium salt concentration in Atlantic salmon slices. They found that equilibrium salt concentrations of pre-rigor, in-rigor, and post-rigor samples were $0.53,0.66$, and $0.75 \mathrm{~g} / \mathrm{g}$ of salt-free solids, respectively, when samples were soaked in a $20 \%$ $(w / v)$ sodium chloride solution at $10^{\circ} \mathrm{C}$. They explained the higher equilibrium salt concentrations for in-rigor and post-rigor fish compared to pre-rigor fish in terms of enzymatic degradation of cellular structures. Perhaps equilibrium salt concentration was lower in pre-rigor fish slices due to the intact membranes that maintained a certain level of osmotic pressure to balance differential salt concentrations in and outside of the cells. In this study, stress may cause the muscle to be more susceptible to gaping, reduce muscle integrity, and breaking down cells that, in turn, softened fillets and enhanced tissue dehydration during brining. Loss of fillet weight due to brining was still greater at $24 \mathrm{~h}$ after stress and was not recovered after $48 \mathrm{~h}$.

\section{Hatching temperature and handling stress interaction}

To interpret the temperature by stress interaction, data have been presented separately. Orthogonal comparisons, as described previously in the ante-mortem handling stress effect, were made.

Fillet weights of the no-stress treatment were lower than stress treatments for fish hatched at $6.5^{\circ} \mathrm{C}$ (Table 5). It is probably due to the fact that fillets from stressed fish after $24 \mathrm{~h}$ recovery contained more water (Table 6). The fillet weight of fish hatched at $9.5^{\circ} \mathrm{C}$ was not affected $(p>0.05)$ by ante-mortem stress. 
Stress lowered $\mathrm{L}^{*}$ value compared to the control for the $6.5^{\circ} \mathrm{C}$ hatching temperature group (Table $5 ; \mathrm{p}<0.05)$. In contrast, stress increased $L^{*}$ for the $9.5^{\circ} \mathrm{C}$ hatching temperature. Muscles of rested fish had $L^{*}$ values close to the no-stress control. Muscle $a^{*}$ values were affected $(p<0.05)$ by stress treatments for each temperature category (Table 5). Muscles of the no-stressed fish had a higher $\mathrm{a}^{*}$ value than those of the stressed fish. According to Jobling and coworkers (1998), consumers prefer the red color of salmonid flesh. Mazeaud and Mazeaud (1981) observed that bleaching was correlated to the presence of plasma adrenaline in carp. Hole (1999) indicated that stress during salmon harvest resulted in color reduction. Resting until $48 \mathrm{~h}$ did not enhance $(p>0.05)$ muscle $a^{*}$ value.

There were linear and quadratic relationships between resting period and brined $\mathrm{pH}$ of the 6.5 and $9.5^{\circ} \mathrm{C}$ groups, respectively $(\mathrm{p}<0.05$; Table 7$)$. The relationship between ante-mortem handling stress and rate of $\mathrm{pH}$ declined has been reported in both land animals and fish (Bendall and Swatland, 1988; Erikson et al., 1997). Lowe and coworkers (1993) demonstrated that rigor onset and muscle ATP depletion were delayed in unstressed fish and were more rapid in exercised fish. Jerrett and coworkers (1996) concluded that there was no difference in $\mathrm{pH}$ and lactate content between rested and exhausted Chinook salmon white muscle after $40-\mathrm{h}$ ice storage.

Stress did not affect $(p>0.05)$ cook yield for fish hatched at $6.5^{\circ} \mathrm{C}$ (Table 7). There was a quadratic relationship $(p<0.05)$ between resting period and fillet 
cook yield for the $9.5^{\circ} \mathrm{C}$ category. Decreased cook yield was associated with increased product moisture in rested fish from the $9.5^{\circ} \mathrm{C}$ category.

Total and water-phase salt content of products produced from fish hatched at $6.5^{\circ} \mathrm{C}$ was not different $(p>0.05)$ for all stress treatment comparisons (Table 7). In contrast, stress increased total and water-phase salt content of products from fish hatched at $9.5^{\circ} \mathrm{C}$. The effect was minimized after the $24-\mathrm{h}$ resting period. A stress-induced softening of muscle may have enhanced the penetration of salt into the tissues.

Stress did not affect $(p>0.05)$ shear force of fillets from fish hatched at $6.5^{\circ} \mathrm{C}$ (Table 7). Gomez-Guillen and coworkers (2000) reported no differences in shear strength of the myofibrillar fraction between stressed and no-stressed fish as determined by Warner-Bratzler shear. In this work, decreased shear force in the no-stress control of the $9.5^{\circ} \mathrm{C}$ group may have been due to the higher moisture and fat content of these products (Table 6).

$L^{*}, a^{*}$ and $b^{*}$ values of smoked fillets were affected $(p<0.05)$ by stress for the $6.5^{\circ} \mathrm{C}$ hatching temperature group (Table 8). There was no difference ( $p>0.05$ ) for cooked $L^{*}$ for all stress treatment comparisons in the $9.5^{\circ} \mathrm{C}$ group. The control for both temperature groups had higher $a^{*}$ values than the stress without rest treatment. Resting period did not affect $(p>0.05) a^{*}$ of products for the $6.5^{\circ} \mathrm{C}$ group. Cooked $\mathrm{a}^{*}$ and $\mathrm{b}^{*}$ values of fillets from fish hatched at $9.5^{\circ} \mathrm{C}$ was enhanced after resting $24 \mathrm{~h}$. Crawford and coworkers (1970) reported poorer color (brown) in canned skipjack tuna produced from exercised and rested fish held at $0^{\circ} \mathrm{C}$ and frozen. Little (1972) suggested that post-mortem 
denaturation of myoglobin inhibited the conversion to hemochrome, the pigment responsible for the typical color of canned tuna. In the present study, perhaps stress caused biochemical changes in some tissue components that affected the interaction between smoke and those components.

Proximate composition of smoked products was not different between control and stress treatments, except for protein and ash of the $9.5^{\circ} \mathrm{C}$ hatching temperature group (Table 6). Consequences of stress on lipid metabolism, especially on plasma free fatty acid level, are far from clear. Stress may increase or decrease free fatty acid level in carp depending on the experiments (Mazeaud and Mazeaud, 1981). Gomez-Guillen and coworkers (2000) observed that there was no great difference in proximate composition of raw fish having different stress treatments. Variation in fish size within each treatment combination of this experiment may explain the inability to detect differences in composition as a function of stress treatment. The effect of stress treatment and resting period on ash content for the $9.5^{\circ} \mathrm{C}$ group corresponded with those occurring in total and water-phase salt content. In addition, stress may stimulate adrenaline, releasing calcium into muscle and, in turn, affect ash content. Relative to hatching temperature and stress susceptibility, mineral homeostasis may be affected by a greater predisposition to stress by the $9.5^{\circ} \mathrm{C}$ group, resulting in more mineral in the muscle of these fish. 


\section{CONCLUSIONS}

Stress resulted in reduced gut weight and $a^{*}$ value, affected $L^{*}$ value, and increased fillet weight loss after brining. Fish hatched at $9.5^{\circ} \mathrm{C}$ appeared to be more sensitive to handling stress than fish hatched at $6.5^{\circ} \mathrm{C}$ based on salt and ash content of the smoked products. Resting for $24 \mathrm{~h}$ after stress decreased total and water-phase salt, and ash content. Resting $48 \mathrm{~h}$ increased gut weight and enhanced muscle $L^{*}$ but did not enhance muscle $a^{*}$. Because of the variation in fish size, a primary problem in Arctic charr cultivation, differences in cook yield, shear force, and proximate composition could not be determined. Muscle of fish from the small size group was darker compared to the large and medium size groups. Smoked fillets produced from the small size category had a higher protein and fat content, and a lower moisture content compared to the large size category. 


\section{REFERENCES}

Ando,M., Toyohara,H., and Sakaguchi,M. 1992. Postmortem tenderization of rainbow trout muscle caused by the disintegration of collagen fibers in the pericellular connective tissue. Nippon S. Gakkaishi. 58: 567-570.

AOAC. 1990. Official Methods of Analysis. $15^{\text {th }}$ ed. Washington, DC:Association of Official Analytical Chemists.

Bendall,J.R. and Swatland,H.J. 1988. A review of the relationship of $\mathrm{pH}$ with physical aspects of pork quality. Meat Sci. 24(2): 85-126.

Berg,T., Erikson,U., and Nordtvedt,T.S. 1997. Rigor mortis assessment of Atlantic salmon (Salmo salar). J. Food Sci. 62(3): 439-446.

Crawford,L., Irwin,E.J., Spinelli,J., and Brown,W.D. 1970. Premortem stress and postmortem biochemical changes in skipjack tuna and their relation to quality of the canned product. J. Food Sci. 35(6): 849-851.

de March,B.G.E. 1995. Effects of incubation temperature on the hatching success of Arctic charr eggs. The Progressive Fish-Culturist. 57: 495-507.

de March,B.G.E. 1997. Social and genetic determinants of size variation in tanks of Nauyuk, Norwegian and hybrid Arctic charr, Salvelinus alpinus (L.). aquaculture research. $28: 305-315$.

Doe,P.E.. 1982. Fish Drying \& Smoking: Production and Quality. Lancaster:Technomic Publishing Company, Inc. 250 p.

Dunajski,E. 1979. Texture of fish muscle. J. Texture Studies. 10(4): 301-317.

Erikson,U., Beyer,A.R., and Sigholt,T. 1997. Muscle high-energy phosphates and stress affect K-values during ice storage of Atlantic salmon (Salmo salar). J. Food Sci. 62(1): 43-47.

Federal Register. 1995. Procedures for the safe and sanitary processing and importing of fish and fishery products. Federal Register. 60(242): 65161-65163.

Ferguson,R.A., Kieffer,J.D., and Tufts,B.L. 1993. The effects of body size on the acid-base and metabolite status in the white muscle of rainbow trout before and after exhaustive exercise. J. Exp. Biol. 180: 195-207.

Gillet,C. 1991. Egg production in an Arctic charr (Salvelinus alpinus L.) brood stock: effects of temperature on the timing of spawning and the quality of eggs. Aquatic Living Resources. 4: 109-116. 
Gomez-Gilluen,M.C., Montero,P., Hurtado,O., and Borderias,A.J. 2000.

Biological characteristics affect the quality of farmed Atlantic salmon and smoked muscle. J. Food Sci. 53(1): 60-65.

Grafflin,A.L. 1931. Urine flow and diuresis in marine teleost. Am. J. Physiol. 97: 602-610.

Hatlen,B., Arnesen,A.M., and Jobling,M. 1996. Muscle carotenoid concentrations in sexually maturing and imature Arctic charr, Salvelinus alpinus (L.), fed astaxanthin. Aquaculture Nutrition. 2(207): 212.

Heinitz,M.L. and Johnson,J.M. 1998. The incidence of Listeria spp., Salmonella spp., and Clostridium botulinum in smoked fish and shellfish. J. Food Prot. 61(3): 318-323.

Hole,R. 1999. Harvesting salmon for quality. Fish Farmer. 22(6): 43-44.

Iwamoto,M., Yamanaka,H., Watabe,S., and Hashimoto,K. 1987. Effect of storage temperature on rigor-mortis and ATP degradation in plaice (Paralichthys olivaceus) muscle. J. Food Sci. 52(6): 1514-1517.

Jerrett,A.R., Stevens,J., and Holland,A.J. 1996. Tensile properties of white muscle in rested and exhausted chinook salmon (Oncorhynchus tshawytscha). J. Food Sci. 61(3): 527-532.

Jobling,M. 1994. Fish Bioenergetics. New York:Chapman \& Hall Inc. 309p.

Jobling,M., Tveiten,H., and Hatlen,B. 1998. Cultivation of Arctic charr: an update. Aqua. Int. 6(3): 181-196.

Jobling,M., Jorgensen,E.H., Arnesen,A.M., and Ringo,E. 1993. Feeding, growth and environment requirements of Arctic charr: A review of aquaculture potential. Aqua. Int. 1(1): 20-46.

Jungwirth,M. and Winkler,H. 1984. The temperature dependence of embryonic development of grayling (Thymallus thymallus), Danube salmon (Hucho hucho), Arctic charr (Salvelinus alpinus) and brown trout (Salmo trutta fario). Aquaculture. 38(4): 315-327.

Little,A.C. 1972. Effect of pre- and post-mortem handling on reflectance characteristics of canned skipjack tuna. J. Food Sci. 37(3): 502.

Lowe,T.E., Ryder,J.M., Carragher,J.F., and Wells,R.M.G. 1993. Flesh quality in snapper, Pagrus auratus, affected by capture stress. J. Food Sci. 58(4): 770-773, 796.

Mazeaud,M.M. and Mazeaud,F. 1981. Adrenergic responses to stress in fish. In: A.D.Pickering, editor. Stress and Fish. New York:Academic Press Inc. p. 65-67. 
Mazeaud,M.M., Mazeaud,F., and Donaldson,E.M. 1977. Primary and secondary effects of stress in fish: Some new data with a general review. Tran. Am. Fish. Soc. 106(3): 201-212.

Nakayama,T., Toyoda,T., and Ooi,A. 1994. Physical property of carp muscle during rigor tension generation. Fish. Sci. 60(6): 717-722.

Northeastern Regional Aquaculture Center. 2000. Aquaculture species of the Northeast. Factsheet 130.

www.umassd.edu/specialprograms/nrac/factsheets/fact 130.

Pate,E.E. and Brokaw,C.J. 1980. Cross-bridge behavior in rigor-mortis. Biophys. Struct. Mech. 7: 51-54.

SAS Institute Inc. 1989. SAS users guide: Basics version 6.06. Statistical Analysis System Institute Inc. Cary, NC.

Shearer,K.D. 1994. Factors affecting the proximate composition of cultured fishes with emphasis on salmonids. Aquaculture. 119: 63-88.

Sigholt,T., Erikson,U., Rustad,T., Johansen,S., Nordtvedt,T.S., and Seland,A. 1997. Handling stress and storage temperature affect meat quality of farmedraised Atlantic salmon (Salmo salar). J. Food Sci. 62(4): 898-905.

Stroud,G.D. 1968. Rigor in fish-The effect on qulaity. Torry Advisory Note. Issue no.36: 11.

Tsuchiya,H., Kita,S., and Seki,N. 1992. Postmortem changes in actinin and connectin in carp and rainbow trout muscles. Nippon S. Gakkaishi. 58: 793-798.

Tveiten,H., Johnsen,H.K., and Jobling,M. 1996. Influence of maturity status on the annual cycles of feeding and growth in Arctic charr reared at constant temperature. J. Fish Biology. 48(5): 910-924.

Wang,D., Tang,J., Correia,L.R., and Gill,T.A. 1998. Postmortem changes of cultivated Atlantic salmon and their effects on salt uptake. J. Food Sci. 63(4): 634-637.

Watabe,S., Kamal,M., and Hashimoto,K. 1991. Postmortem changes in ATP, creatine phosphate, and lactate in sardine muscle. J. Food Sci. 56(1): 151-153. 
Table 1. Effect of hatching temperature on body characteristics, muscle $b^{*}$, and brine uptake.

\begin{tabular}{lcc}
\hline \multirow{2}{*}{ Trait } & \multicolumn{2}{c}{ Hatching temperature, ${ }^{\circ} \mathrm{C}$} \\
\cline { 2 - 3 } Fork length, mm & 36.5 & 9.5 \\
Whole body wt, g & $717.91^{\mathrm{a}}$ & $359.31^{\mathrm{a}}$ \\
Gut wt, g & $91.72^{\mathrm{a}}$ & $717.47^{\mathrm{a}}$ \\
Gonad wt, g & $57.01^{\mathrm{y}}$ & $76.09^{\mathrm{a}}$ \\
Head wt, g & $79.03^{\mathrm{a}}$ & $35.29^{\mathrm{x}}$ \\
Frame wt, g & $71.08^{\mathrm{a}}$ & $74.67^{\mathrm{a}}$ \\
Muscle b* & $10.52^{\mathrm{a}}$ & $70.47^{\mathrm{a}}$ \\
Brine uptake, \% & $-5.02^{\mathrm{b}}$ & $9.97^{\mathrm{a}}$ \\
\hline
\end{tabular}

${ }^{a b}$ Means within each response with different superscripts are different $(p<0.05)$.

${ }^{x y}$ Means within each response with different superscripts are different $(p<0.10)$. 
Table 2. Effect of size category on body characteristics and muscle color.

\begin{tabular}{|c|c|c|c|}
\hline \multirow{2}{*}{ Trait } & \multicolumn{3}{|c|}{ Size category } \\
\hline & Large & Medium & Small \\
\hline Fork length, mm & $366.07^{a}$ & $363.65^{a}$ & $354.43^{a}$ \\
\hline Whole body wt, g & $731.12^{a}$ & $726.00^{a}$ & $695.95^{a}$ \\
\hline Gut wt, g & $89.85^{a}$ & $89.39^{a}$ & $72.47^{a}$ \\
\hline Gonad wt, g & $52.76^{a}$ & $51.09^{a}$ & $54.60^{\mathrm{a}}$ \\
\hline Head wt, g & $82.49^{a}$ & $75.29^{a}$ & $72.75^{a}$ \\
\hline Frame wt, g & $73.30^{a}$ & $71.69^{a}$ & $67.32^{\mathrm{a}}$ \\
\hline Fillet wt, g & $477.07^{a}$ & $475.84^{\mathrm{a}}$ & $472.77^{a}$ \\
\hline Muscle L* & $49.07^{b}$ & $48.62^{b}$ & $45.85^{a}$ \\
\hline Muscle $a^{*}$ & $-0.70^{a}$ & $-0.72^{a}$ & $-0.51^{a}$ \\
\hline Muscle $b^{*}$ & $10.51^{a}$ & $10.52^{a}$ & $9.72^{a}$ \\
\hline
\end{tabular}

${ }^{a b}$ Means within each response with different superscripts are different $(p<0.05)$. 
Table 3. Effect of size category on smoked fish characteristics.

\begin{tabular}{|c|c|c|c|}
\hline \multirow{2}{*}{ Trait } & \multicolumn{3}{|c|}{ Size category } \\
\hline & Large & Medium & Small \\
\hline Brined $\mathrm{pH}$ & $6.37^{b}$ & $6.32^{\mathrm{ab}}$ & $6.28^{a}$ \\
\hline Brine uptake, \% & $-5.18^{a}$ & $-5.30^{a}$ & $-5.78^{a}$ \\
\hline Cook yield, \% & $74.75^{a}$ & $74.80^{\mathrm{a}}$ & $76.07^{a}$ \\
\hline Salt content, \% & $0.90^{a}$ & $0.92^{a}$ & $0.92^{a}$ \\
\hline Water-phase salt, \% & $1.27^{\mathrm{a}}$ & $1.33^{a}$ & $1.34^{\mathrm{a}}$ \\
\hline$L^{*}$ & $54.30^{a}$ & $54.49^{a}$ & $55.16^{\mathrm{a}}$ \\
\hline$a^{*}$ & $6.54^{a}$ & $6.96^{a}$ & $7.01^{a}$ \\
\hline$b^{*}$ & $38.29^{a}$ & $39.24^{a b}$ & $39.52^{b}$ \\
\hline Shear force, $\mathrm{g}$ & $1997^{a}$ & $2068^{a}$ & $2093^{a}$ \\
\hline Moisture, \% & $66.58^{b}$ & $65.77^{\mathrm{ab}}$ & $64.96^{\mathrm{a}}$ \\
\hline Fat, \% & $5.60^{a}$ & $5.99^{a}$ & $6.56^{a}$ \\
\hline Protein, \% & $24.54^{a}$ & $24.80^{\mathrm{ab}}$ & $25.08^{b}$ \\
\hline Ash, \% & $2.88^{a}$ & $2.89^{a}$ & $2.77^{a}$ \\
\hline
\end{tabular}

${ }^{a b}$ Means within each response with different superscripts are different $(p<0.05)$. 
Table 4. Effect of stress on body characteristics, muscle $b^{*}$, and brine uptake.

\begin{tabular}{|c|c|c|c|c|c|}
\hline \multirow{2}{*}{ Trait } & \multicolumn{4}{|c|}{ Stress treatment } & \multirow{2}{*}{$\begin{array}{l}\text { Orthogonal } \\
\text { comparison** }\end{array}$} \\
\hline & No-stress & Stress without rest & Stress+24-h rest & Stress+48-h rest & \\
\hline Fork length, mm & 362.45 & 357.35 & 360.37 & 365.36 & - \\
\hline Whole body wt, g & 712.21 & 690.54 & 725.30 & 742.70 & - \\
\hline Gut wt, g & 98.44 & 72.13 & 76.89 & 88.16 & $A, L$ \\
\hline Gonad wt, g & 53.29 & 36.80 & 39.04 & 55.47 & - \\
\hline Head wt, $g$ & 76.77 & 75.60 & 78.68 & 76.34 & - \\
\hline Frame wt, $g$ & 67.73 & 69.00 & 73.12 & 73.24 & - \\
\hline Muscle $b^{*}$ & 10.27 & 9.87 & 10.46 & 10.40 & - \\
\hline Brine uptake, \% & -4.99 & -5.23 & -6.10 & -5.37 & $A, Q$ \\
\hline
\end{tabular}

${ }^{* *} A$ : Comparison of the no-stress to all stress treatments $(3-1-1-1 ; p<0.05)$.

$L$ : Linear relationship between resting period and response $(0-101 ; p<0.05)$.

$Q$ : Quadratic relationship between resting period and response $(0-12-1 ; p<0.05)$.

-: There was no difference for all comparisons ( $p>0.05)$. 
Table 5. Hatching temperature by stress interaction for fillet weight, and muscle $L^{*}$ and $a^{*}$.

\begin{tabular}{|c|c|c|c|c|c|c|c|c|c|c|c|}
\hline \multirow[b]{2}{*}{ Trait } & \multicolumn{4}{|c|}{$6.5^{\circ} \mathrm{C}$ Hatching temperature } & \multirow[b]{2}{*}{ 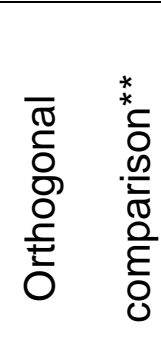 } & \multicolumn{4}{|c|}{$9.5^{\circ} \mathrm{C}$ Hatching temperature } & \multirow[b]{2}{*}{ 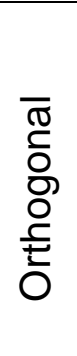 } & \multirow[b]{2}{*}{ 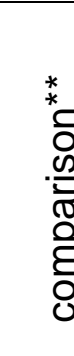 } \\
\hline & $\begin{array}{c}\text { No- } \\
\text { stress }\end{array}$ & $\begin{array}{c}\text { Stress } \\
\text { without } \\
\text { rest }\end{array}$ & $\begin{array}{c}\text { Stress } \\
+ \\
\text { 24-h rest }\end{array}$ & $\begin{array}{c}\text { Stress } \\
+ \\
\text { 48-h rest }\end{array}$ & & $\begin{array}{l}\text { No- } \\
\text { stress }\end{array}$ & $\begin{array}{c}\text { Stress } \\
\text { without } \\
\text { rest }\end{array}$ & $\begin{array}{c}\text { Stress } \\
+ \\
\text { 24-h rest }\end{array}$ & $\begin{array}{c}\text { Stress } \\
+ \\
\text { 48-h rest }\end{array}$ & & \\
\hline Fillet wt, $g$ & 403.22 & 478.49 & 468.39 & 514.43 & A & 518.14 & 464.68 & 499.89 & 472.58 & & - \\
\hline Muscle L* & 50.44 & 47.31 & 48.04 & 49.28 & $A, Q$ & 46.35 & 48.53 & 46.79 & 46.01 & & Q \\
\hline Muscle $a^{*}$ & 0.30 & -0.93 & -1.20 & -1.00 & $A$ & -0.19 & -0.64 & -0.70 & -0.82 & & $A$ \\
\hline
\end{tabular}

${ }^{* *} \mathrm{~A}$ : Comparison of the no-stress to all stress treatments $(3-1-1-1 ; p<0.05)$.

$\mathrm{Q}$ : Quadratic relationship between resting period and response $(0-12-1 ; p<0.05)$.

-: There was no difference for all comparisons ( $p>0.05)$. 
Table 6. Hatching temperature by stress interaction for proximate composition of smoked fillets.

\begin{tabular}{|c|c|c|c|c|c|c|c|c|c|c|c|}
\hline \multirow[b]{2}{*}{ Composition, \% } & \multicolumn{4}{|c|}{$6.5^{\circ} \mathrm{C}$ Hatching temperature } & \multirow{2}{*}{\multicolumn{2}{|c|}{ 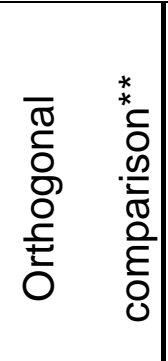 }} & \multicolumn{4}{|c|}{$9.5^{\circ} \mathrm{C}$ Hatching temperature } & \multirow[b]{2}{*}{ 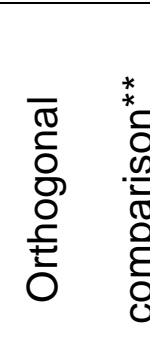 } \\
\hline & $\begin{array}{l}\text { No- } \\
\text { stress }\end{array}$ & $\begin{array}{l}\text { Stress } \\
\text { without } \\
\text { rest }\end{array}$ & $\begin{array}{c}\text { Stress } \\
+ \\
\text { 24-h rest }\end{array}$ & $\begin{array}{c}\text { Stress } \\
+ \\
\text { 48-h rest }\end{array}$ & & & $\begin{array}{c}\text { No- } \\
\text { stress }\end{array}$ & $\begin{array}{c}\text { Stress } \\
\text { without } \\
\text { rest }\end{array}$ & $\begin{array}{c}\text { Stress } \\
+ \\
\text { 24-h rest }\end{array}$ & $\begin{array}{c}\text { Stress } \\
+ \\
\text { 48-h rest }\end{array}$ & \\
\hline Moisture & 65.67 & 65.58 & 65.78 & 66.71 & $\mathrm{~L}$ & L & 65.84 & 65.77 & 65.72 & 66.04 & - \\
\hline Fat & 6.13 & 6.30 & 5.86 & 4.80 & $\mathrm{~L}$ & L & 6.51 & 5.97 & 7.26 & 6.56 & Q \\
\hline Protein & 24.82 & 24.87 & 24.94 & 24.70 & - & - & 24.29 & 24.93 & 25.01 & 24.93 & A \\
\hline Ash & 2.96 & 2.78 & 2.84 & 2.90 & - & - & 2.59 & 3.01 & 2.73 & 2.79 & $A, Q$ \\
\hline
\end{tabular}

${ }^{* *} A$ : Comparison for the no-stress to all stress treatments $(3-1-1-1 ; p<0.05)$.

$L$ : Linear relationship between resting period and response $(0-101 ; p<0.05)$.

$Q:$ Quadratic relationship between resting period and response $(0-12-1 ; p<0.05)$.

-: There was no difference for all comparisons ( $p>0.05)$. 
Table 7. Hatching temperature by stress interaction for smoked fillet characteristics.

\begin{tabular}{|c|c|c|c|c|c|c|c|c|c|c|c|c|}
\hline \multirow[b]{2}{*}{ Trait } & \multicolumn{4}{|c|}{$6.5^{\circ} \mathrm{C}$ Hatching temperature } & \multirow{2}{*}{\multicolumn{2}{|c|}{ 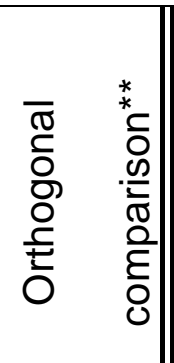 }} & \multicolumn{4}{|c|}{$9.5^{\circ} \mathrm{C}$ Hatching temperature } & \multirow[b]{2}{*}{ 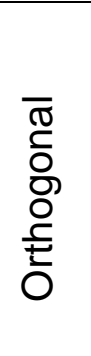 } & \multirow[b]{2}{*}{ 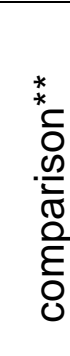 } \\
\hline & $\begin{array}{c}\text { No- } \\
\text { stress }\end{array}$ & $\begin{array}{c}\text { Stress } \\
\text { without } \\
\text { rest }\end{array}$ & $\begin{array}{c}\text { Stress } \\
+ \\
\text { 24-h rest }\end{array}$ & $\begin{array}{c}\text { Stress } \\
+ \\
\text { 48-h rest }\end{array}$ & & & $\begin{array}{l}\text { No- } \\
\text { stress }\end{array}$ & $\begin{array}{c}\text { Stress } \\
\text { without } \\
\text { rest }\end{array}$ & $\begin{array}{c}\text { Stress } \\
+ \\
\text { 24-h rest }\end{array}$ & $\begin{array}{c}\text { Stress } \\
+ \\
\text { 48-h rest }\end{array}$ & & \\
\hline Brine $\mathrm{pH}$ & 6.34 & 6.29 & 6.36 & 6.39 & & L & 6.31 & 6.30 & 6.37 & 6.35 & & Q \\
\hline Cook yield, \% & 74.16 & 76.35 & 75.01 & 73.98 & & - & 76.43 & 73.70 & 75.32 & 74.70 & & Q \\
\hline Salt content, \% & 0.93 & 0.89 & 0.91 & 0.89 & - & - & 0.86 & 1.05 & 0.89 & 0.88 & & Q \\
\hline Water-phase salt, \% & 1.33 & 1.27 & 1.34 & 1.26 & & - & 1.23 & 1.52 & 1.28 & 1.27 & & Q \\
\hline Shear force, $g$ & 2144 & 1976 & 2103 & 2082 & - & - & 1863 & 2046 & 2034 & 2172 & & $A$ \\
\hline
\end{tabular}

${ }^{* *} A$ : Comparison for the no-stress to all stress treatments $(3-1-1-1 ; p<0.05)$.

$L$ : Linear relationship between resting period and response $(0-101 ; p<0.05)$.

$Q$ : Quadratic relationship between resting period response $(0-12-1 ; p<0.05)$.

-: There was no difference for all comparisons ( $p>0.05)$. 
Table 8 . Hatching temperature by stress interaction for color of smoked fillets.

\begin{tabular}{|c|c|c|c|c|c|c|c|c|c|c|c|}
\hline \multirow[b]{2}{*}{ Color } & \multicolumn{4}{|c|}{$6.5^{\circ} \mathrm{C}$ Hatching temperature } & \multirow{2}{*}{\multicolumn{2}{|c|}{ 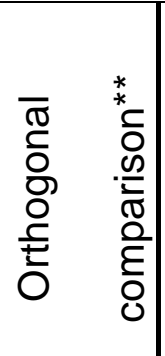 }} & \multicolumn{4}{|c|}{$9.5^{\circ} \mathrm{C}$ Hatching temperature } & \multirow[b]{2}{*}{ 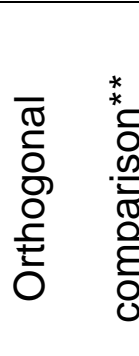 } \\
\hline & $\begin{array}{c}\text { No- } \\
\text { stress }\end{array}$ & $\begin{array}{l}\text { Stress } \\
\text { without } \\
\text { rest }\end{array}$ & $\begin{array}{c}\text { Stress } \\
+ \\
\text { 24-h rest }\end{array}$ & $\begin{array}{c}\text { Stress } \\
+ \\
\text { 48-h rest }\end{array}$ & & & $\begin{array}{l}\text { No- } \\
\text { stress }\end{array}$ & $\begin{array}{l}\text { Stress } \\
\text { without } \\
\text { rest }\end{array}$ & $\begin{array}{c}\text { Stress } \\
+ \\
\text { 24-h rest }\end{array}$ & $\begin{array}{c}\text { Stress } \\
+ \\
\text { 48-h rest }\end{array}$ & \\
\hline$L^{*}$ & 53.48 & 55.76 & 55.40 & 54.34 & $A$ & $A$ & 54.27 & 54.46 & 55.08 & 54.41 & - \\
\hline$a^{*}$ & 7.16 & 6.28 & 6.08 & 6.57 & $A$ & $A$ & 7.54 & 6.34 & 7.59 & 7.12 & $A, Q$ \\
\hline$b^{*}$ & 37.60 & 38.86 & 38.72 & 38.86 & $A$ & $A$ & 39.44 & 38.25 & 40.77 & 39.62 & $Q$ \\
\hline
\end{tabular}

${ }^{* *} A$ : Comparison for the no-stress to all stress treatments $(3-1-1-1 ; p<0.05)$.

$\mathrm{Q}$ : Quadratic comparison between resting period and response $(0-12-1 ; p<0.05)$.

-: There was no difference for all comparisons $(p>0.05)$. 


\section{APPENDICES}




\section{APPENDIX 1}

\section{NUMBERS OF FISH, AVERAGE FISH WEIGHT,}

AND BIOMASS AFTER SIZE GRADING

\begin{tabular}{lcccc}
\hline $\begin{array}{l}\text { Hatching } \\
\text { temperature, }{ }^{\circ} \mathrm{C}\end{array}$ & $\begin{array}{c}\text { Size } \\
\text { grouping }\end{array}$ & $\begin{array}{c}\text { Numbers of } \\
\text { fish }\end{array}$ & $\begin{array}{c}\text { Average } \\
\text { fish wt., } g\end{array}$ & Bio-mass, kg \\
\hline 6.5 & large & 1300 & 10.1 & 17.4 \\
6.5 & medium & 2200 & 8.5 & 19.1 \\
6.5 & small & 3250 & 5.3 & 16.8 \\
9.5 & large & 950 & 34.8 & 33.6 \\
9.5 & & & & 31.6 \\
9.5 & medium & 1350 & 21.0 & 36.0 \\
\hline
\end{tabular}




\section{APPENDIX 2}

\section{NUMBERS OF FISH IN EACH TREATMENT COMBINATION}

\begin{tabular}{|c|c|c|c|c|c|c|c|c|c|c|c|}
\hline \multirow{3}{*}{ Stress treatment } & \multicolumn{6}{|c|}{$6.5^{\circ} \mathrm{C}$ Hatching temperature } & \multicolumn{5}{|c|}{$9.5^{\circ} \mathrm{C}$ Hatching temperature } \\
\hline & \multicolumn{2}{|c|}{ Large $^{*}$} & \multicolumn{2}{|c|}{ Medium } & \multicolumn{2}{|c|}{ Small } & \multicolumn{2}{|c|}{ Large } & \multicolumn{2}{|c|}{ Medium } & \multirow{2}{*}{$\begin{array}{c}\text { Smal } \\
\mathrm{R} 1\end{array}$} \\
\hline & $\mathrm{R} 1^{\text {**}}$ & R2 & R1 & R2 & R1 & $\mathrm{R} 2$ & R1 & $\mathrm{R} 2$ & R1 & R2 & \\
\hline No-stress & 5 & 5 & 5 & 5 & 5 & 5 & 5 & 5 & 5 & 5 & 10 \\
\hline Stress without rest & 5 & 5 & 5 & 5 & 5 & 5 & 5 & 5 & 5 & 5 & 10 \\
\hline Stress +24 -h rest & 5 & 5 & 5 & 5 & 5 & 5 & 5 & 5 & 5 & 5 & 10 \\
\hline Stress + 48-h rest & 5 & 5 & 5 & 5 & 5 & 4 & 5 & 4 & 5 & 5 & 10 \\
\hline Total fish in main plot & 20 & 20 & 20 & 20 & 20 & 19 & 20 & 19 & 20 & 20 & 40 \\
\hline Total fish & \multicolumn{11}{|c|}{238} \\
\hline
\end{tabular}

* Size catagory.

${ }^{* *}$ Replication. 


\section{APPENDIX 3}

\section{NUMBERS OF FILLET IN EACH THICKNESS GROUP}

\begin{tabular}{lcc}
\multicolumn{2}{c}{ Thickness, cm } & Numbers of fillet \\
\hline $1.85-2.70$ & $(0.85)$ & 59 \\
$2.71-3.00$ & $(0.29)$ & 55 \\
$3.01-3.30$ & $(0.29)$ & 56 \\
$3.31-4.37$ & $(1.06)$ & 68 \\
\hline
\end{tabular}

Numbers in parenthesis represent the difference between the upper and the lower level. 


\section{APPENDIX 4}

FORK LENGTH, WHOLE BODY WEIGHT,

FILLET WEIGHT AND THICKNESS, AND FISH GENDER IN EACH MAIN PLOT

\begin{tabular}{|c|c|c|c|c|c|c|c|}
\hline & \multirow{2}{*}{ Overall } & \multicolumn{3}{|c|}{$6.5^{\circ} \mathrm{C}$ Hatching temperature } & \multicolumn{3}{|c|}{$9.5^{\circ} \mathrm{C}$ Hatching temperature } \\
\hline & & Large $^{*}$ & Medium & Small & Large & Medium & Small \\
\hline Fork length, mm & $279-469$ & $307-436$ & $310-422$ & $279-432$ & $300-419$ & $289-469$ & $285-442$ \\
\hline Whole wt, g & $261-1736$ & $350-1223$ & $344-1185$ & $340-1102$ & $359-1216$ & $409-1736$ & 261-1272 \\
\hline Fillet wt, $g$ & $155-1243$ & 209-899 & $187-879$ & $155-763$ & $229-884$ & $246-1243$ & 179-952 \\
\hline Fillet thickness, cm & $1.85-4.37$ & $1.99-4.29$ & $1.63-4.37$ & $1.90-4.20$ & $2.35-3.83$ & $1.85-4.09$ & $1.89-4.01$ \\
\hline Gender ${ }^{\star *}$ fish & $108-115-15$ & $14-24-2$ & $11-23-6$ & $16-20-3$ & $22-15-2$ & $21-19-0$ & $24-12-2$ \\
\hline
\end{tabular}

*Size category.

${ }^{* *}$ Male-female-unidentified gender. 


\section{APPENDIX 5}

\section{STATISTICAL PROGRAM}

\section{FOR RESPONSES PRIOR TO THERMAL PROCESSING}

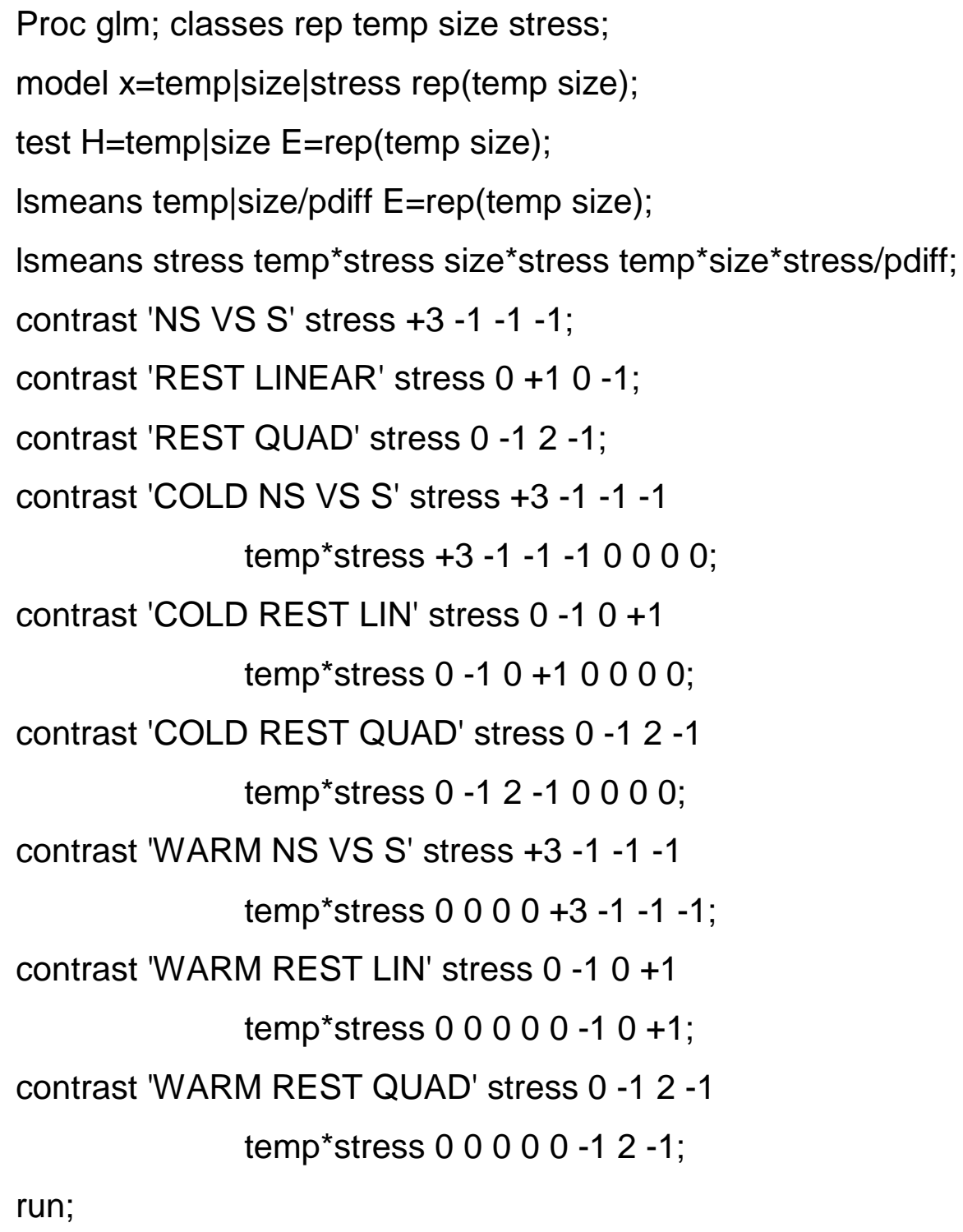




\section{STATISTICAL PROGRAM}

\section{FOR RESPONSES FOLLOWING THERMAL PROCESSING}

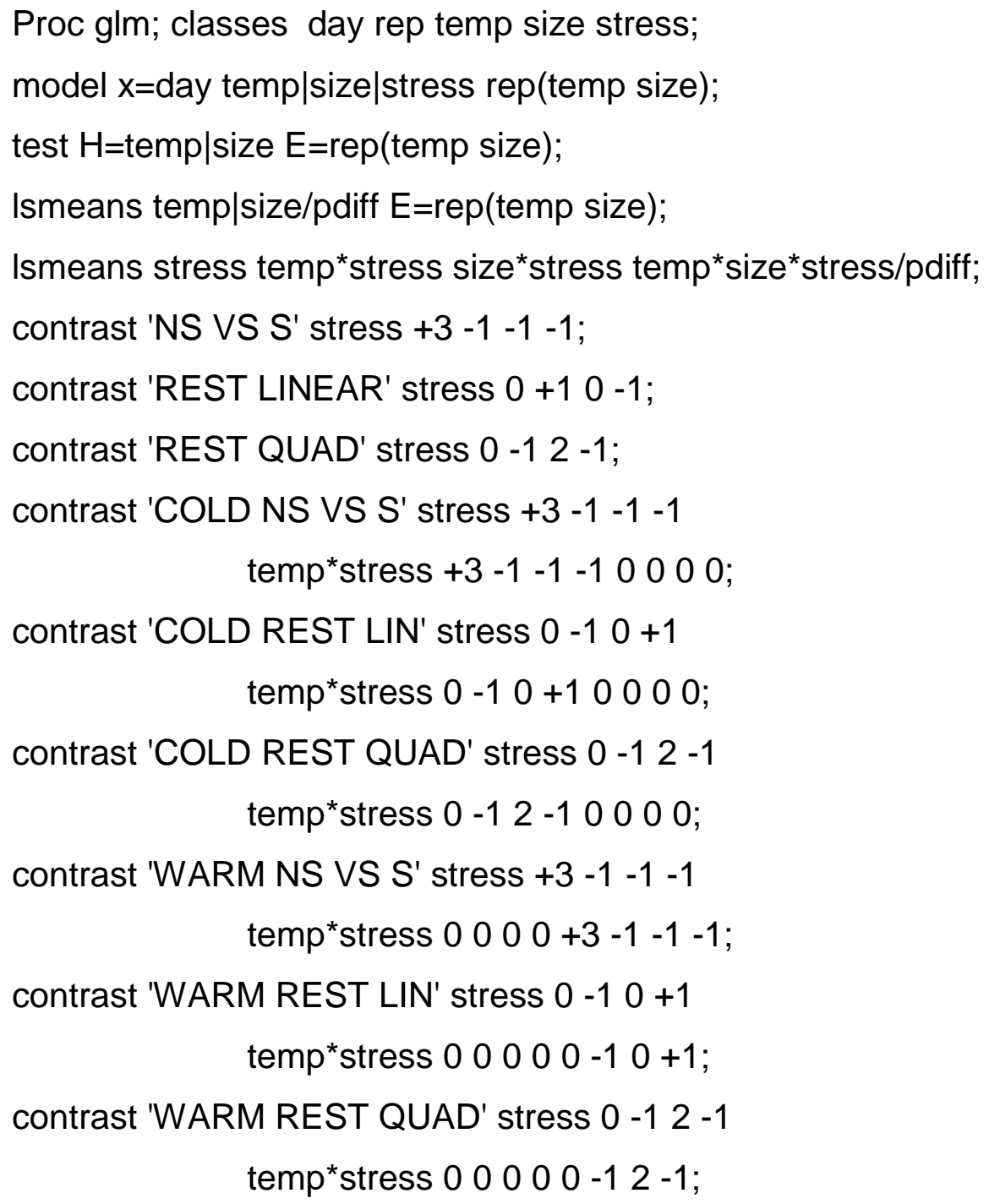

run; 


\section{CHAPTER 3}

FROZEN STORAGE AND CYOPROTECTION EFFECTS ON HYSICOCHEMICAL ATTRIBUTES OF

INTACT RAINBOW TROUT, Oncorhynchus mykiss, FILLETS

AND THE QUALITY OF SMOKED PRODUCTS 


\section{ABSTRACT}

Quality deterioration associated with freeze-induced protein denaturation is commonly observed in frozen fish. Cryoprotectants would minimize deleterious effects of frozen storage on physiochemical properties of myofibrillar proteins and improve texture development, processing yields, and quality of smoked fish products produced from these frozen fillets. Rainbow trout, Oncorhynchus mykiss, were filleted within $3 \mathrm{~h}$ of harvest and held overnight at $3^{\circ} \mathrm{C}$ before cryoprotectant treatments were applied. Stabilization of trout fillets by water, $1 \%(\mathrm{w} / \mathrm{v})$ sodium lactate, or $8 \%(\mathrm{w} / \mathrm{v})$ sucrose/sorbitol $(1: 1 \mathrm{w} / \mathrm{w})$, alone or in combination with $0.5 \% \quad(\mathrm{w} / \mathrm{v})$ sodium tripolyphosphate/tetrasodium pyrophosphate $(1: 1 \mathrm{w} / \mathrm{w})$ and/or $0.05 \%(\mathrm{w} / \mathrm{v})$ magnesium chloride was investigated. A $3 \times 2 \times 2$ factorial, randomized incomplete block design was conducted with three replications. Treatments were nested within cryoprotectant. After soaking in aforementioned treatment solutions, fillets were vacuum packed and stored at $-20^{\circ} \mathrm{C}$ for 90 days. In addition, fillets without soaking were assigned as another control. Total protein and myofibrillar protein solubility, total myosin, aliphatic hydrophobicity, total, free and disulfide sulfhydryl content, myosin and actin transition temperatures, and endogenous protease activity were determined. Smoked fillets and trout mince were prepared, and muscle color, brined and cooked $\mathrm{pH}$, brine uptake, cook yield, shear force, total and waterphase salt content, and proximate composition were measured. Mince was used for texture profile (hardness and cohesiveness) evaluations. All responses were determined prior to and after frozen storage. The general linear model procedure 
of SAS was used to determine main and interaction effects. Cryoprotectants minimized the negative effects of frozen storage on physiochemical traits of myofibrillar proteins. Sucrose/sorbitol and sodium lactate increased total protein and myofibrillar protein solubility, and decreased surface hydrophobicity, total, free and disulfide sulfhydryl content, and myosin susceptibility to thermal denaturation $(p<0.05)$ compared to the no-soak control. There were no differences $(p>0.05)$ in total protein solubility and actin susceptibility to thermal denaturation between cryoprotectants and the water control. Phosphate enhanced the cryoprotective effect on myofibrillar protein solubility, surface hydrophobicity, and myosin susceptibility to thermal denaturation $(p<0.05)$. Magnesium chloride tended to accelerate protein denaturation during frozen storage by decreasing myosin solubility, and increasing disulfide sulfhydryl content $(p<0.05)$. Treatments did not affect total myosin and endogenous protease activity. $L^{*}, a^{*}$, and $b^{*}$ values of fillets following treatment with cryoprotectants and freezing, were lower than untreated and water-soaked fillets. Cryoprotectants preserved quality of frozen trout fillets that were subsequently used for smoked trout production. Sucrose/sorbitol and sodium lactate improved hardness and cohesiveness of cooked mince. These cryoprotectants increased cook yield, $\mathrm{pH}$, and fat content of smoked fillets compared to the no-soak and water controls $(p<0.05)$. Frozen storage increased $(p<0.05)$ fillet weight loss after brining, total and water-phase salt content, brined and cooked ash, and decreased $(p<0.05)$ fillet shear force. Sucrose/sorbitol provided more effective 
cryoprotection than sodium lactate in preservation of protein structure and improved the quality of smoked products.

Keywords: trout, cryoprotection, sucrose/sorbitol, sodium lactate, phosphate, magnesium chloride, proteins, physicochemical traits, smoked fish 


\section{INTRODUCTION}

Frozen storage is an excellent preservation method for extended periods of time. It maintains chemical and microbiological stability of food products without causing major changes in size, shape, texture, color, and flavor. However, deterioration of food texture, resulting from biochemical, enzymatic, and functional changes in proteins is a problem associated with formation of ice crystals that is an integral part of the freezing process. Ice crystals penetrate fragile membranes causing release of enclosed contents and change the microenvironments within the food. Freeze-induced protein denaturation and related functionality losses are commonly observed in frozen muscle foods, especially fish (Sikorski et al., 1976; Miller et al., 1980; Borderias et al., 1982; Hsu et al., 1993; Zotos et al., 1995; Hurling and McArthur, 1996).

Three accepted theories are presented to explain alterations in the protein microenvironment that cause protein denaturation during freezing and frozen storage. They are: 1) an increase in solute concentration, 2) dehydration of the cell, and 3) autoxidative changes that alter the balance of protein-protein and protein-water interactions. As freezing progresses, proteins are exposed to increased ionic strength in the non-frozen aqueous phase that leads to extensive modification of protein native structure (Fukumi et al., 1965; Park et al., 1987b; Lin and Park, 1998). In a dehydrated state, protein-water interactions in tissue are disrupted and protein molecules are exposed to an organic environment that is less polar than water. These changes result in increased exposure of hydrophobic side chains and therefore changes in protein conformation (Privalov 
et al., 1986; Franks, 1995). Recent studies have demonstrated that autoxidative changes, such as lipid oxidation, are involved in denaturation and deterioration of muscle protein functionality by causing cross-linking between protein and lipid oxidation products (Wang et al., 1997; Srinivasan and Xiong., 1996; Srinivasan and Xiong, 1997).

In a preliminary study of the chemical and physical changes in smoked rainbow trout associated with frozen storage, $78-\mathrm{d}$ storage at $-20^{\circ} \mathrm{C}$ produced poorer quality fish compared to fresh product (Appendix 1). Frozen storage increased total soluble proteins, and decreased myosin and actin solubility. These changes were observed as reduced hardness of cooked mince and shear force of smoked fillets by $86 \%$ and $55 \%$, respectively, and it tended to decrease cohesiveness. Decreased fat content of the smoked products prepared from frozen fillets may have been due to decreased structural integrity and reduced ability to retain fat.

Cryoprotectants improve quality and extend shelf life of frozen foods by preventing deleterious changes in myofibrillar proteins caused by freezing, frozen storage, and thawing (MacDonald and Lanier, 1997). There are many cryoprotectants used in various frozen foods. A sucrose/sorbitol mixture is commercially used in minced fish products because of availability and low cost (Lee, 1984). However, there is an interest in identifying other cryoprotectants with reduced sweetness and potential for Maillard browning reaction (Park et al., 1987a; Park et al, 1988; Park and Lanier, 1987). MacDonald and Lanier (1994) reported that sodium lactate stabilized tilapia actomyosin in model systems 
against freeze-thaw and heat denaturation. Sodium lactate was more effective than sucrose at the same concentration. They suggested that sodium lactate had good potential as a cryoprotectant and actomyosin stabilizer. Phosphate have been reported to enhance protein functionality during frozen storage (Mahon and Schneider, 1964; Park and Lanier, 1987; Park et al., 1988) and magnesium chloride facilitated protein-water interactions and texture development in low fat, low sodium restructured beef and beef batter (Pojedinec, 1999; Pigott et al., 1999). Rainbow trout is an important farm fish produced in the northeast region of the United States. Increased trout production will require frozen storage for distribution and inventory control. In the context of the hypothesis that cryoprotectants will minimize the deleterious effect of frozen storage on physicochemical properties of myofibrillar proteins, this experiment was conducted to evaluate the effectiveness of sucrose/sorbitol or sodium lactate as cryoprotectants and determine if phosphate or magnesium chloride had an additive effect on stabilizing physicochemical attributes of intact frozen fillets. In addition, the utility of these frozen fillets in smoked trout production was evaluated.

\section{MATERIALS AND METHODS}

\section{Chemicals}

Pure sucrose, sodium lactate $(60 \% \mathrm{w} / \mathrm{w})$, and magnesium chloride were purchased from Sigma-Aldrich (St. Louis, MO). Pure Sorbitol was purchased from Fisher Scientific Co. (Pittsburgh, PA). Sodium tripolyphosphate (food 
grade) and tetrasodium pyrophosphate (food grade) were purchased from FMC Corp. (Princeton, NJ).

Fish samples

Rainbow trout, Oncorhynchus mykiss, were obtained from one farm. These fish were starved for $3 \mathrm{~d}$ prior to harvest. At harvest, fish $(362 \pm 50 \mathrm{~g})$ were taken directly from the water, packed on ice, and transported to the processing laboratory where fish were immediately filleted. Following filleting, the "fillet" is described as a butterfly fillet. Transit time did not exceed $3.5 \mathrm{~h}$. Fillets were washed in dilute ice brine and rinsed under cold tap water to remove blood and waste. Following cleaning, fillets were drained overnight at $3^{\circ} \mathrm{C}$ to remove excess water and allow muscle $\mathrm{pH}$ to reach its ultimate value.

\section{Cryoprotectant soaking protocol}

Three cryoprotectant treatments (water, $1 \%(\mathrm{w} / \mathrm{v})$ sodium lactate, and $8 \%$ $(\mathrm{w} / \mathrm{v})$ sucrose/sorbitol $(1: 1 \mathrm{w} / \mathrm{w}))$ by two phosphate treatments $(0$ and $0.5 \%(\mathrm{w} / \mathrm{v})$ sodium tripolyphosphate/tetrasodium pyrophosphate) by two magnesium chloride treatments $(0$ and $0.05 \%)$ resulted in twelve treatment combinations. After draining, eight fillets were soaked in each treatment combination solution for 90 min at $3^{\circ} \mathrm{C}$. A fillet to solution ratio of $1 \mathrm{~kg}$ of fillet to $2 \mathrm{~L}$ of solution was used. Additionally, fillets that were not soaked represented a control. Following soaking, fillets were drained for $30 \mathrm{~s}$. Four of the eight fillets were randomly sampled at either 0 (fresh) or following 90-d frozen storage. Each group was vacuum packed (Ultravac ${ }^{\circledR}$, Model UV500, Koch; Kansas City, MO) in a polyethylene bag and stored overnight at $3^{\circ} \mathrm{C}$ for cryoprotectant equilibration. On 
the following day, fillets assigned to the frozen storage group were transferred to frozen storage $\left(-20^{\circ} \mathrm{C}\right)$.

\section{Fillet processing}

Fillets were soaked in $8.7 \%(\mathrm{w} / \mathrm{v})$ sodium chloride solution for $90 \mathrm{~min}$ at $3^{\circ} \mathrm{C}$. Frozen fillets were thawed at $3^{\circ} \mathrm{C}$ overnight before processing. Light brown sugar was added at $69 \%(\mathrm{w} / \mathrm{w})$ of the sodium chloride required for the brine. A fillet to brine ratio of 1 fillet (approximately $246 \pm 35 \mathrm{~g}$ ) to $1.4 \mathrm{~L}$ of brine was used. Fillets from each treatment combination were brined in separate containers. Following brining, fillets were drained and placed on stainless steel expanded metal racks with skin down for $24 \mathrm{~h}$ at $3^{\circ} \mathrm{C}$. This time was chosen to allow brine equilibration and pellicle formation. Fillets were covered with polyethylene wrap $4 \mathrm{~h}$ after draining to prevent excessive drying.

Brined fillets were processed in a microprocessor-controlled smokeoven (Enviro-Pak, Model CVU-490; Clackamas, OR) to an internal temperature of $65.5^{\circ} \mathrm{C}$ and held for $50 \mathrm{~min}$. The heating process met the minimum requirements described by the FDA Fish and Fishery Products Hazards and Controls Guide, 21 CFR 123 (Federal Register, 1995). After cooking, smoked fillets were cooled at ambient temperature for $30 \mathrm{~min}$, at $3^{\circ} \mathrm{C}$ for an additional $30 \mathrm{~min}$, and packed in polyethylene bags. Samples were stored at $3^{\circ} \mathrm{C}$, and cooked product analyses were carried out within $24 \mathrm{~h}$.

\section{Gel processing}

One brined fillet from each treatment combination was skinned and minced in a Cuisinart ${ }^{\circledR}$ food processor for three, 15-s intervals, interrupted by 
two, 15-s intervals. Mince was stuffed into two, 2.8-cm (ID), 50-mL polypropylene, centrifuge tubes. Following stuffing, tubes were placed in a $45^{\circ} \mathrm{C}$ water bath until the gel temperature reached $42^{\circ} \mathrm{C}$. At this time, water bath temperature was increased to $72^{\circ} \mathrm{C}$, and gels were removed from the water bath when the internal temperature reached $65.5^{\circ} \mathrm{C}$. Internal temperature was monitored with a Beckman Industrial Datalogger (Model 205, Beckman Instruments; Fullerton, CA) equipped with a copper-constant thermocouple (Omega Technologies; Stamford, CT). Total cooking time was 45 min. After cooking, gels were cooled to ambient temperature before transfer to $4^{\circ} \mathrm{C}$. Gels were used for texture profile analysis, and the remaining raw mince was used for determination of proximate composition.

\section{Sample preparation for physicochemical analysis of raw fillets}

Before smoke processing, one fillet was randomly selected for physicochemical analyses. Fillets were skinned, cut into small pieces (excluding belly flap), frozen in liquid nitrogen, and powdered in a pre-chilled commercial Waring Blender for 2-3 min. Powdered samples were used for protein qualification and quantification and for determination of endogenous muscle protease activity. Powdered samples were stored at $-70^{\circ} \mathrm{C}$ until analyses for total myosin were performed.

\section{Sample preparation for determining smoked fillet quality}

One side of each smoked fillet was randomly selected, and a $2.54 \times 8 \mathrm{~cm}$ strip of the dorsal musculature was cut for fillet texture analyses. Dunajski (1979) indicated that body composition of cultured rainbow trout, Oncorhynchus mykiss, 
was not different based on side. Immediately following this measurement, the sheared fillet was collected in a whirl-pak ${ }^{\circledR}$ bag for determination of total and water-phase salt.

The remaining side was skinned, cut into small pieces, frozen in liquid nitrogen, and powdered in a pre-chilled commercial Waring Blender for 2-3 min. Samples were stored at $-20^{\circ} \mathrm{C}$ until cooked $\mathrm{pH}$ and proximate composition were determined.

\section{Chemical and physical analysis}

Color measurement: Surface color was measured with a chromameter (Minolta, Model CR-300, Minolta Camera Co. Ltd.; Osaka, Japan) before freezing for fresh samples (after soaking in treatment combination solutions) and after thawing for frozen samples. The instrument was calibrated using a standard white plate No.21333180 (CIE L* 93.1; $a^{*} 0.3135 ; b^{*} 0.3198$ ), and L* (lightness), $a^{*}$ (redness), and $b^{*}$ (yellowness) values were recorded at two randomly chosen locations at the cranial and caudal end of the fillet. These values were averaged and used as the observation for that fillet.

pH: Sample pH was measured using a pH/ion analyzer 350 (Corning Inc.; Corning, NY) equipped with a flat surface combination probe. The $\mathrm{pH}$ was recorded for all fillets prior to soaking (muscle raw $\mathrm{pH}$ ), after soaking for fillets in the fresh group, and after thawing for fillets in the frozen group. Fillet $\mathrm{pH}$ was measured at the cranial end of the dorsal musculature above the lateral line. Five grams of powdered, cooked sample were mixed with $50-\mathrm{mL}$ distilled water 
for $\mathrm{pH}$ determination. The $\mathrm{pH}$ of treatment combination solutions were recorded (Figure 1).

Solution uptake: Individual fillets in the fresh group were weighed before and after soaking in treatment solutions. Solution uptake was calculated as the difference between the before and after soaking weights, and expressed as percent of the fillet weight.

Brine uptake and cook yield: Fillets were weighed before brining. This weight corresponds to 1) the weight after soaking in treatment solutions for the fresh group, and 2) the weight after thawing for fillets in the frozen group. Fillets were also weighed after brining and again after thermal processing. Brine uptake was calculated as the difference between the before and after brining weights, and it was expressed as percent of the weight before brining. Cook yield was expressed as percent of the pre-brined fillet weight. For the fish gel, individual gels were lightly rolled over filter paper to remove excess moisture and weighed to determine cooked weight. For cook yield, cooked weight was expressed as a percent of the raw mince weight.

Total and water-phase salt content: Salt content of cooked fish was determined by the Indicating Strip Method (No. 971.19; AOAC, 1990). This method uses the Quantab ${ }^{\circledR}$ chloride titrator (Environmental Test Systems, Inc.; Elkhart, IN), No.711196, and has a range of $0.05-1.0 \%$ sodium chloride. After 9:1 dilution, the effective sodium chloride range for the product is 0.5 to $10 \%$. Ten grams of chopped, cooked sample were mixed with $90 \mathrm{~mL}$ of hot water. The slurry was filtered through Whatman No. 41 filter paper, and sodium chloride 
content was calculated by multiplying the strip reading for sodium by 10 . Moisture content was determined by drying a 3-g of sample collected from the shear test at $103 \pm 1^{\circ} \mathrm{C}$ for $24 \mathrm{~h}$. Percent water-phase salt was calculated as (g sodium chloride $\times 100) /(g$ sodium chloride $+\mathrm{g}$ moisture) (Heinitz and Johnson, 1998).

Proximate composition: Proximate composition was determined using AOAC (1990) approved methods.

Protein qualification and quantification: Ten grams of raw, powdered sample were blended with $100 \mathrm{~mL}$ of $2.56 \%(\mathrm{w} / \mathrm{v})$ sodium chloride solution (ionic strength 0.44; $\mathrm{pH}$ 6.5) in a Stomacher 400 blender (Tekmar; Cincinnati, $\mathrm{OH}$ ) for $30 \mathrm{~s}$. This slurry was centrifuged for $30 \mathrm{~min}$ at $4^{\circ} \mathrm{C}$ in a Damon IEC B200A (870 head, $8 \times 50 \mathrm{~mL}$ tubes) refrigerated centrifuge (Fisher Scientific Co.; Pittsburgh, PA) at $7000 \mathrm{xg}$, as measured at the top of the centrifuge tube. The supernatant was filtered two times through Whatman No. 41 filter paper. The filtrate was then used in analysis of total protein solubility, protein surface hydrophobicity, and sulfhydryl and disulfide content. Total soluble protein concentration was determined by the Biuret method using bovine serum albumin as the standard (Gornall et al., 1949). Aliphatic surface hydrophobicity was determined using cisparinaric acid (CPA) (Molecular Probes, Inc.; Eugene, OR) as a probe according to the procedure of Kato and Nakai (1980) with modifications described by Kenney and coworkers (1992) and Lin and Park (1998). Surface hydrophobicity was expressed as the slope of relative fluorescent intensity versus protein concentration. Free sulfhydryls and sulfhydryls derived from disulfide linkages 
were quantified using Ellman's reagent, 5,5'-dithiobis-2-nitrobenzoic acid (SigmaAldrich; St. Louis, MO) as described by Beveridge and coworkers (1974). Myofibrillar proteins (soluble myosin and actin) were separated using sodium dodecyl sulfate, polyacrylamide gel electrophoresis (SDS-PAGE) (Greaser et al., 1983). One gram of raw, powdered sample was homogenized with $100 \mathrm{~mL}$ of cold deionized, distilled water with a Polytron homogenizer (Model Polytron PT10-35, Fisher Scientific Co.; Pittsburgh, PA) for 1 min (Srinivasan et al., 1997). Total myosin was determined using sodium dodecyl sulfate, polyacrylamide gel electrophoresis (SDS-PAGE) (Fritz et al., 1989).

Differential scanning calorimetry (DSC): Differential scanning calorimetry was performed on a TA Instruments DSC 2910 (TA Instruments, Inc.; New Castle, DE). Raw, powdered samples weighing 10-15 mg, to an accuracy of $\pm 0.01 \mathrm{mg}$, were sealed in a volatile sample pan (hermetic pan; part no. 900796.901). Reference pans contained an equal weight of deionized, distilled water. Samples were scanned at a heating rate of $10^{\circ} \mathrm{C} / \mathrm{min}$ from 20 to $95^{\circ} \mathrm{C}$. Duplicate samples were analyzed at a calorimetric sensitivity of $3 \mu \mathrm{w}$. Peak temperatures corresponding to transition temperatures for myosin and actin were recorded. Since baseline was difficult to mark, apparent enthalpies of denaturation (peak areas) were not estimated.

Protease activity: Measurement of endogeneous protease activity was performed as described by An and coworkers (1994a), and Wang and Xiong (1998). Crude enzyme extract was prepared by blending raw, powdered sample with cold deionized, distilled water at a 1:1 ratio in a Stomacher 400 blender 
(Tekmar; Cincinnati, OH) for 2 min. This slurry was centrifuged for 30 min at $4^{\circ} \mathrm{C}$ in a Damon IEC B200A (870 head, $8 \times 50 \mathrm{~mL}$ tubes) refrigerated centrifuge (Fisher Scientific Co.; Pittsburgh, PA) at $17500 \times x$, as measured at the top of the centrifuge tube. The supernatant was collected and used as crude enzyme extract. Results from the preliminary experiment showed the dependence of endogenous protease activity on $\mathrm{pH}$ and temperature. Optimum activity was observed at $60^{\circ} \mathrm{C}$ for $\mathrm{pH} 5$ and at $70^{\circ} \mathrm{C}$ for $\mathrm{pH} 6.5$. To determine proteolytic activity in the present study, the reacting medium was adjusted to $\mathrm{pH} 6.5$ using Mcllvaine's buffer and samples were incubated at $70^{\circ} \mathrm{C}$ for $1 \mathrm{~h}$. This $\mathrm{pH}$ is similar to the $\mathrm{pH}$ of fish muscle and temperature is near the end point cooking temperature of smoked fillets and model system gels.

Texture characteristics: Gel texture was evaluated according to Texture Profile Analysis (Bourne, 1978) using a Texture Analyser (Model TA-HDi ${ }^{\circledR}$, Texture Technologies Corp.; Scarsdale, NY). Gels were cut into cores $(1.91 \mathrm{~cm}$ diameter, $1.27 \mathrm{~cm}$ high). For two cycles, each core was axially compressed between two parallel plates at $127 \mathrm{~mm} / \mathrm{min}$ to $50 \%$ of its original height. Hardness is defined as peak force of the first compression and cohesiveness is defined as the ratio of positive peak force area during the second compression to that of the first compression (Bourne, 1978). For cooked fillets, a $2.5 \times 8 \mathrm{~cm}$ strip of the dorsal musculature was removed. Shear force was measured with a 5blade Kramer shear attachment. The piece was skinned, weighed, and placed beneath the blades with the pellicle side down. Peak shear force and treatment values were expressed as $g$ force/g of sampleExperimental design 
This study was conducted a $3 \times 2 \times 2+1$ factorial, randomized incomplete block design. Factor A consisted of two types of cryoprotectant; $1 \%(\mathrm{w} / \mathrm{v})$ sodium lactate and $8 \%(\mathrm{w} / \mathrm{v})$ sucrose/sorbitol mixture $(1: 1 \mathrm{w} / \mathrm{w})$, and water as a control. Factor B was the level of sodium tripolyphosphate/tetrasodium pyrophosphate mixture $(1: 1 \mathrm{w} / \mathrm{w})$ at 0 and $0.50 \%(\mathrm{w} / \mathrm{v})$. Factor $\mathrm{C}$ was the level of magnesium chloride at 0 and $0.05 \%(\mathrm{w} / \mathrm{v})$. Day was the blocking factor and treatments were nested within type of cryoprotectant. In addition, fillets without soaking were assigned as another control in each block. Thus, thirteen treatments were replicated three times. Responses were determined at $0 \mathrm{~d}$ and 90- $d$ frozen storage.

The General Linear Model (GLM) procedure of SAS (SAS Institute, Inc., 1989) was conducted to establish main and interaction effects. The PDIFF of the Ismeans procedure was used to separate means. A significance level of $p<0.05$ was accepted. The following three, statistical analyses were performed: 1) frozen storage effects for the no-soak control, 2) treatment effects prior to freezing, and 3) treatment effects following frozen storage.

\section{RESULTS AND DISCUSSION}

Frozen storage affected physicochemical attributes of intact fillets and the quality of smoked products (Table 1). Total and myofibrillar protein solubility, transition temperature of myosin, $L^{*}$ and $a^{*}$ values, brine uptake, hardness and cohesiveness of cooked mince, and fillet shear force decreased following frozen storage $(p<0.05)$. There were the increases $(p<0.05)$ in protein surface hydrophobicity, total, free and disulfide sulfhydryl content, total and water-phase 
salt content, brined and cooked ash. Muscle $\mathrm{pH}$, total myosin, transition temperature of actin, endogenous protease activity, $b^{*}$ value, brined moisture, fat

and protein content, and cook yield, $\mathrm{pH}$, moisture, fat, and protein content of smoked fillets were not affected by frozen storage $(p>0.05)$.

\section{Solution uptake}

Solution uptake was greatest $(p<0.05)$ for fillets soaked in water followed by $1 \%$ sodium lactate (Figure 2 ). A small weight loss was observed after soaking in $8 \%$ sucrose/sorbitol solution. Osmosis depends on the concentration of solute in tissues relative to solute concentration of the surrounding solution. A high concentration of sucrose/sorbitol caused water to migrate from the fillets. Phosphate and magnesium chloride did not affect $(p>0.05)$ solution uptake (Figures 3 and 4).

\section{Muscle pH}

The $\mathrm{pH}$ of water, $1 \%$ sodium lactate, and $8 \%$ sucrose/sorbitol solutions was $7.34,6.49$, and 7.85 , respectively (Figure 1 ). Addition of $0.5 \%$ phosphate increased $\mathrm{pH}$ of water and cryoprotectant solutions. Water $\mathrm{pH}$ decreased as $0.05 \%$ magnesium chloride was added. When magnesium chloride was added with phosphate, the increase in $\mathrm{pH}$ was not as great as phosphate alone.

The ultimate $\mathrm{pH}$ of the no-soaked fillets was 6.43. Foegeding and coworkers (1996) reported a range of 6.2-6.6 for ultimate $\mathrm{pH}$ of lean white fish. After soaking in water and cryoprotectant solutions, muscle pH increased to 6.446.47 , depending on the $\mathrm{pH}$ of the solutions (Figure 5). A slightly lower $\mathrm{pH}$ was observed after frozen storage. This lower $\mathrm{pH}$ may be due to increased solute 
concentration. Park and coworkers (1993) reported that $\mathrm{pH}$ of pre- (6.5) and post-rigor (5.6) beef tissues gradually decreased to 5.4 after 5-m frozen storage at $-28^{\circ} \mathrm{C}$.

Phosphate increased $(p<0.05)$ muscle $\mathrm{pH}$ by 0.06 units relative to untreated, water and cryoprotectant-soaked fillets in the fresh group (Table 2). Magnesium chloride did not affect $(p>0.05) \mathrm{pH}$ of fresh and frozen muscle (Table 3).

\section{Total protein solubility (TPS)}

Sodium lactate and sucrose/sorbitol increased $(p<0.05)$ TPS compared to the no-soak control for fresh and frozen products (Figure 6). These increases are probably associated with the solubility of myofibrillar proteins. However, cryoprotectant provided no significant increase compared to water ( $p>0.05)$.

Frozen storage decreased TPS. Grujic and coworkers (1993) indicated that muscle fiber damage during slow freezing was caused by intercellular ice crystal formation. Myofibrils were compressed and deformed. Fissures were noted in the Z-line region, caused by loss of water and its movement from hydration centers on the protein chain. These changes facilitated formation of cross bonds and protein denaturation. Decreases in protein solubility during frozen storage have been reported in minced trout (Moral et al., 1986), hake fillets (Owusu-Ansah and Hultin, 1986), minced cod (Tejada et al., 1996), and hake actomyosin (del Mazo et al., 1999). Park and coworkers (1993) reported that rate of decline in total extractable protein was greatest during the first $3 \mathrm{~m}$ of frozen storage and had little change from 3 to $5 \mathrm{~m}$. The decline in total 
extractable protein during $3 \mathrm{~m}$ corresponded to decline in $\mathrm{pH}$ over the same period. The greatest decline in TPS occurred in the water treatment. Cryoprotectant treatments maintained a higher TPS than the no-soak treatment during frozen storage. Sucrose/sorbitol caused the highest TPS in frozen samples. This supports the ability of sucrose/sorbitol to reduce protein denaturation; sodium lactate had less ability to reduce protein denaturation during frozen storage.

Phosphate increased $(p<0,05)$ TPS in fresh and frozen groups compared to the no-soak control (Table 2). TPS, although not significantly different, compared to water- and cryoprotectant-soaked treatments. Park and coworkers (1993) reported a slight increase and a pronounced effect on total extractable protein for polydextrose, and phosphate, respectively, in post-rigor, ground beef muscle. Phosphate effects on TPS may be due to phosphate formation of complexes with calcium that, in turn, loosens tissue structure (Lindsay, 1996). Magnesium chloride did not affect $(p>0.05)$ TPS (Table 3$)$.

\section{Myosin solubility}

Initially, there was no difference $(p>0.05)$ in myosin solubility among nosoak, water, and cryoprotectant treatments (Figure 7). MacDonald and Lanier (1994) measured the recovered $\mathrm{Ca}^{2+}$-stimulated ATPase activity as an indication of protein denaturation and found that increasing concentrations of sucrose and sodium lactate depressed $\mathrm{Ca}^{2+}$-stimulated ATPase activity of unfrozen tilapia actomyosin. They suggested that this response is due to the structuring effect of sucrose and sodium lactate on water that, in turn, reduced the mobility of water 
molecules and slowed the rate of ATP hydrolysis. It may also be due to ability of sucrose and sodium lactate to increase the surface tension of water, and in turn excludes solutes from protein and its hydration area. MacDonald and coworkers (1996) hypothesized that lactate bound calcium ions and would reduce $\mathrm{Ca}^{2+}$ stimulated ATPase activity with increasing sodium lactate concentration. After 90 $d$ of frozen storage, the decrease in myosin solubility occurred in the no-soaked fillets (Table $1 ; p<0.05)$. Changes that proteins undergo during freezing and frozen storage promote protein-protein interactions, reducing protein extractability in sodium chloride solution. Buttkus (1970) reported decreased protein solubility in trout myosin solutions stored at $0,-10,-20$, and $-30^{\circ} \mathrm{C}$ for 14 d. He noted that the general patterns of decline of myosin solubility in whole muscle and in purified myosin samples during frozen storage are similar; nonetheless denaturation of purified myosin was accelerated. When myosin was frozen in a solution of $0.45 \mathrm{M}$ potassium chloride containing $0.026 \mathrm{M}$ mono- and dipotassium phosphate $(\mathrm{pH}$ 6.9, ionic strength 0.5$)$, large molecular weight aggregates formed that could be centrifuged out of solution at low centrifuged fields. del Mazo and coworkers (1999) reported that extracted protein decreased as frozen storage progressed, with myosin solubility most affected. Changes were apparent in the myosin heavy chain. Myosin solubility of fillets soaked in sodium lactate and sucrose/sorbitol solutions was higher compared to both controls following frozen storage (Figure $7 ; \mathrm{p}<0.05$ ). MacDonald and Lanier (1994) found that increasing the concentration of sucrose (up to 25\%) and sodium lactate (up to $6 \%$ ) increased $\mathrm{Ca}^{2+}$-stimulated ATPase activity in the 
freeze-thaw samples. Following freezing, increased myosin solubility $(p<0.05)$ was observed in the water control compared to the no-soak treatment. Increased water uptake during soaking may decrease solute concentration prior to freezing that minimizes protein denaturation following frozen storage.

Phosphate increased $(p<0.05)$ myosin solubility in frozen samples relative to both controls (Table 2); this response may be due to the increase in $\mathrm{pH}$ or the ability to dissociate actomyosin (Trout and Schmidt, 1983). Srinivasan and Xiong (1997) found that the formation of nondisulfide linkages were almost absent in washed beef heart surimi when sodium tripolyphosphate was used. Paredi and coworkers (1996) indicated that polyphosphates delayed the decrease in $\mathrm{Mg}^{2+}$ dependent ATPase activity of actomyosin.

Prior to freezing, magnesium chloride did not affect $(p>0.05)$ myosin solubility (Table 3). Pojedinec (1999) reported that magnesium chloride tended to increase myosin solubility in low fat, low sodium restructured beef. Perhaps the magnesium chloride effect was not significant because of the small amount absorbed by the tissue. In addition, differences in product ionic strength and species may account for the different effect of magnesium chloride on myosin solubility. Following frozen storage, magnesium chloride caused decreased $(p<0.05)$ myosin solubility compared to the magnesium chloride control. This may be associated with its contribution to solute concentration and composition during freezing and frozen storage, causing protein denaturation and decreasing myosin solubility. Fukumi and coworkers (1965) reported that freeze-induced denaturation of washed actomyosin from Alaskan Pollock was accelerated by 
magnesium chloride. Sarkar (1950) explained that divalent ions, particularly magnesium, had a great affinity for myosin. At $0.001 \mathrm{M}$ magnesium chloride, there is a shift from an isoelectric point pH of 5.4 in a salt free solution to $\mathrm{pH} 7.6$. This shift at such low levels demonstrated a strong affinity of magnesium for myosin. When magnesium chloride concentration increased from 0.01 to $0.3 \mathrm{M}$, the isoelectric point $\mathrm{pH}$ remained at 7.6 , but there was a great extension of the zone of precipitation, indicating protein-protein interactions.

\section{Total myosin}

There was no difference $(p>0.05)$ in total myosin with regard to frozen storage, cryoprotectant, phosphate, and magnesium chloride (Figure 8 and Tables 2 and 3).

\section{Actin solubility}

Sodium lactate increased $(p<0.05)$ actin solubility of fresh fillets while sucrose/sorbitol had no effect compared to the no-soak and water controls (Figure 9). Frozen storage decreased $(p<0.05)$ actin solubility of the no-soak treatment (Table 1). del Mazo and coworkers (1999) reported that the proportion of actin in natural hake actomyosin remained constant as frozen storage was extended to 49 wk. However, in their previous studies on cod muscle, myosin and actin became less extractable in $0.6 \mathrm{M}$ sodium chloride during frozen storage due to changes in protein-protein bonds formed (Careche et al., 1998). Increased actin solubility in sodium lactate and sucrose/sorbitol treatments demonstrated the protein stabilizing effect of these compounds. The increased $(p<0.05)$ actin solubility of frozen, water-soaked fillets compared to the no-soak 
control may be due to water's dilution of solutes to the point that their contribution to protein denaturation is minimized.

Phosphate increased $(p<0.05)$ actin solubility in fresh and frozen fillets (Table 2). Trout and Schmidt (1983) suggested that phosphate effects on protein solubility are due, in part, to an ability to dissociate actomyosin to actin and myosin. Magnesium chloride increased $(p<0.05)$ actin solubility in frozen samples (Table 3). Such a small amount was used that the response may be due to a specific ion effect. Pojedinec (1999) reported that magnesium chloride effects were dependent on muscle maturity. In C-maturity products containing magnesium chloride, actin solubility was more than in products without magnesium chloride.

\section{Protein surface hydrophobicity $\left(\mathbf{S}_{0}\right)$}

Surface hydrophobicity is a measure of exposed hydrophobic groups on the protein. A higher value suggests increased protein unfolding or denaturation. Surface hydrophobicity can be classified as aliphatic hydrophobicity due to aliphatic amino acid side chains or as aromatic hydrophobicity due to the aromatic amino acid side chains. The cis-parinaric acid (CPA) probe is useful for determining aliphatic hydrophobicity, whereas 1-anilino-8-naphthalene sulfonate (ANS) is useful for determining aromatic hydrophobicity (Kato and Nakai, 1980). In this study, aliphatic hydrophobicity was evaluated.

There was no difference $(p>0.05)$ in surface hydrophobicity between treatments for fresh samples (Figure 10 and Tables 4 and 5). The unsoaked fillets exhibited surface hydrophobicity at 3784. Kenney and coworkers (1992) 
reported a surface hydrophobicity in fish surimi of 4193 . Frozen storage increased $(p<0.05)$ surface hydrophobicity in the no-soak treatment $($ Table 1$)$. According to Ang and Hultin (1989), surface hydrophobicity of cod myosin suspension increased about 10 - and 20 -fold within the initial hour of freezing at -80 and $-25^{\circ} \mathrm{C}$, respectively. At either freezing temperature, no further increase in hydrophobicity occurred during storage up to $40 \mathrm{~h}$. del Mazo and coworkers (1999) reported significant changes in CPA (aliphatic) and ANS (aromatic) hydrophobicity with respect to time from 0 to 50 wk in natural actomyosin extracts from hake. No differences were reported between storage at -20 and $-30^{\circ} \mathrm{C}$. Aliphatic hydrophobicity increased to a greater degree than did aromatic hydrophobicity over storage time. Aliphatic and aromatic hydrophobicity increased from the first weeks of frozen storage, reaching a maximum value after 15 wk. Wang and coworkers (1997) reported that ANS hydrophobicity of cryoprotectant-free beef heart surimi increased markedly after 12 wk when stored at -15 and $-29^{\circ} \mathrm{C}$. The dramatic increase in hydrophobicity in the present study, relative to the aforementioned work, may be due to a slower freezing rate or the difference in protein stability associated with specie. Water, sodium lactate and sucrose/sorbitol decreased $(p<0.05)$ surface hydrophobicity compared to the nosoak control of the frozen group. Sucrose/sorbitol provided the lowest hydrophobicity value. During freezing, Wang and coworkers (1997) indicated that increased ANS hydrophobicity was minimized when sucrose/sorbitol was added to surimi. Hydrophobic interaction is generally considered the most important factor in stabilizing three-dimensional structure of proteins. Back and 
coworkers (1979) showed that hydrophobic interactions between pairs of hydrophobic groups were stronger in sucrose and glycerol solutions than in pure water. The effect of sugars and polyols on hydrophobic interaction depends on how they affect water structure. Perhaps sodium lactate elicits a similar structure-making effect.

Phosphate decreased $(p<0.05)$ surface hydrophobicity compared to the no-soak and water controls for frozen fillets (Table 4). Magnesium chloride in water and cryoprotectant solutions did not affect $(p>0.05)$ surface hydrophobicity (Table 5). However, soaking with or without magnesium chloride decreased $(p<0.05)$ surface hydrophobicity in frozen fillets compared to the no-soak control. del Mazo and coworkers (1999) suggested that changes in extract composition had to be taken into account because myosin, the major protein in the extracts, decreased over time. These variables could affect interpretation of surface hydrophobicity data. Lin and Park (1998) showed that in the absence of potassium chloride and when $\mathrm{pH}$ was decreased from 3 to 2 or increased from 8 to 10, ANS hydrophobicity increased. However, surface hydrophobicity of myosin from $\mathrm{pH} 4$ to 7 could not be measured due to the insolubility of myosin under these conditions. They demonstrated that ANS hydrophobicity increased as potassium chloride increased from 0.02 to $3.8 \mathrm{M}$. This response was due to rupture of ionic linkages, destabilization of the protein structure, and increased exposure of hydrophobic residues.

\section{Total sulfhydryl, free sulfhydryl, and disulfide sulfhydryl content}


Total, free, and disulfide sulfhydryl content are indicators of oxidative changes and the degree of protein polymerization and aggregation. Wang and coworkers (1997) stated that sulfhydryl groups of cysteinyl residues in beef heart muscle were particularly susceptible to oxidation during surimi preparation and subsequent freezing.

Total sulfhydryl content (total SH): The water- and cryoprotectant-soaked treatments resulted in a lower total SH content $(p<0.05)$ than the no-soak control for fresh and frozen groups (Figure 11). Even though myosin is the major component in the extract, changes in extractability of proteins other than myosin may influence total SH content. Frozen storage increased $(p<0.05)$ total $\mathrm{SH}$ in the no-soak treatment (Table 1). Sucrose/sorbitol resulted in the lowest total SH content in frozen fillets that was significantly different $(p<0.05)$ from the no-soak and water controls (Figure 11). Sodium lactate effects on total SH were only lower $(p<0.05)$ than the no-soak control. According to del Mazo and coworkers (1999), changes in total SH were not consistent throughout a 50 -wk storage period. Total $\mathrm{SH}$ content was greater than the initial concentration until approximately $35 \mathrm{wk}$ and then there was a sharp decrease to a concentration less than the initial level. Wang and coworkers (1997) reported total SH progressively decreased during frozen storage and that the concentration was lower than that of fresh beef heart surimi. Their results revealed no difference in total SH concentration over time between cryoprotectant and control treatments. A decrease in total SH content caused by cryoprotectants in the frozen group corresponded with increased soluble myofibrillar proteins. Differences due to 
changes in protein composition of the extracts may account for this negative relationship. Phosphate had no affect $(p>0.05)$ on total $\mathrm{SH}$ in fresh and frozen fillets (Table 4). Magnesium chloride increased $(p<0.05)$ total $\mathrm{SH}$ of the extract compared to water- and cryoprotectant-soaked treatments, but these values were lower $(p<0.05)$ than the no-soak control for frozen samples (Table 5). Lin and Park (1998) reported that a constant total SH content associated with potassium chloride concentration, suggested that salt did not cause disruption or formation of disulfide bonds.

Free sulfhydryl content (free $\mathrm{SH})$ : There was no difference $(p>0.05)$ in free SH among fresh treatments (Figure 12 and Tables 4 and 5). Frozen storage increased $(p<0.05)$ free $\mathrm{SH}$ content in the no-soak control (Table 1). Since increased surface hydrophobicity suggested protein unfolding due to frozen storage, ruptured and unfolded protein structures may have more exposed free $\mathrm{SH}$ groups. Sucrose/sorbitol and sodium lactate lowered free $\mathrm{SH}$ groups compared to both controls, and sucrose/sorbitol was more effective than sodium lactate. This response indicated that sucrose/sorbitol and sodium lactate stabilized protein structure during frozen storage. Jiang and coworkers (1986) reported 56.6 and $50.2 \%$ SH groups in 3-m frozen cod and mackerel actomyosin at $-20^{\circ} \mathrm{C}$, respectively. They suggested that disulfide formation caused protein aggregation during frozen storage that, in turn, decreased $\mathrm{SH}$ groups. Wang and coworkers (1997) reported decreased available SH groups due to frozen storage, and cryoprotectants did not affect the concentration of the available sulfhydryl during frozen storage. Phosphate and magnesium chloride in water and 
cryoprotectant solutions did not affect $(p>0.05)$ free $\mathrm{SH}$ content in fresh and frozen fillets (Tables 4 and 5).

Disulfide sulfhydryl content: Frozen storage induced protein oxidation as observed by increased disulfide sulfhydryl content in the no-soak control (Table $1 ; p<0.05)$. Increasing disulfide covalent bonds during frozen storage has been previously reported (Buttkus, 1970; Jiang et al., 1986; Owusu Ansah and Hultin, 1986; Tejada et al., 1996; del Mazo et al., 1999). Water and cryoprotectants without magnesium chloride decreased $(p<0.05)$ disulfide sulfhydryl content compared to the no-soak control in fresh and frozen groups (Figure 13). This observation indicates that water, sucrose/sorbitol and sodium lactate decreased the degree of protein oxidation during frozen storage. Magnesium chloride in water increased $(p<0.05)$ disulfide sulfhydryl content of fresh and frozen samples, indicats magnesium chloride promoted protein oxidation. Srinivasan and Xiong (1997) observed that protein crosslinking via disulfide bonds was hastened by addition of 0.6 M sodium chloride. Lin and Park (1998) indicated that when ionic linkages of protein structure were ruptured by potassium chloride, protein was partially unfolded. Phosphate did not influence $(p>0.05)$ disulfide formation (Table 4).

\section{Myofibrillar protein susceptibility to thermal denaturation}

Differential scanning calorimetry (DSC) is a useful technique for studying thermal behavior of muscle proteins as a means of gaining information about protein folding and stability in biochemical systems (Wright et al., 1977). This technique has allowed study of thermally induced transitions in fish proteins as a 
function of specie and processing condition (Hastings et al., 1985; Park and Lanier, 1989). DSC results are recorded as "thermograms", which are plots of the differential heat input against temperature. As temperature rises, heatinduced, endothermic protein unfolding occurs. Changes in protein structure during DSC analysis are referred to as "transition" changes, and peak temperatures are used to represent transition temperatures. A lower transition temperature indicates that the protein is more susceptible to thermal denaturation. Different fish species possess different transition temperatures for myofibrillar proteins (Hastings et al., 1985). The transition temperatures of myosin and actin in fresh rainbow trout muscle are 47.98 and $78.02^{\circ} \mathrm{C}$, respectively.

Myosin susceptibility to thermal denaturation: Frozen storage increased $(p<0.05)$ myosin susceptibility to thermal denaturation by lowering the transition temperature from 47.98 to $46.67^{\circ} \mathrm{C}$ (Table 1). Cryoprotectants increased myosin transition temperature compared to the no-soak and water controls in fresh and frozen samples (Figure 14). Sucrose/sorbitol and sodium lactate enhanced myosin stability in fresh samples. Addition of $50 \%(\mathrm{w} / \mathrm{w})$ glucose, sucrose and sorbitol have been reported to raise the transition temperatures of $\alpha$ chymotrypsinogen in glycine buffer, conalbumin in phosphate buffer, and lysozyme (Back et al., 1979). They concluded that this stabilization was due to the effects of sugars and polyols on hydrophobic interactions. The extent of stabilization by different sugars and polyols was explained by their different influences on water structure. Polydextrose ${ }^{\circledR}$ increased myosin transition 
temperature in unfrozen ground beef (Park et al., 1993). Hastings and coworkers (1985) reported that freezing followed by immediate thawing had little effect on thermal transitions in cod muscle. However, after 2 wk at $-10^{\circ} \mathrm{C}$, a greater myosin susceptibility to thermal denaturation occurred. Little change in myosin transition temperature was observed subsequently until 10 wk. Park and coworkers (1993) reported that decreased myosin transition temperatures in post-rigor ground beef were due to frozen storage. Results, comparable to the present study, have been reported when using Polydextrose ${ }^{\circledR}$ as a cryoprotectant in fresh and frozen samples (Park et al., 1993).

Phosphate decreased $(p<0.05)$ myosin susceptibility to thermal denaturation in frozen samples (Table 6). Park and coworkers (1993) found that phosphate decreased the shift in transition temperature of these peaks that have been increased by Polydextrose ${ }^{\circledR}$. Findlay and Barbut (1992) indicated that tripolyphosphate did not affect transition temperature of myosin. Transition temperature of myosin was lower, although not significant, in the presence of magnesium chloride (Table 7). Varunsatian and coworkers (1983) reported that denaturation temperature of whey protein concentrates decreased in the presence of magnesium chloride. This trend observed for myosin may be due to magnesium's affinity for myosin that affected its conformational stability.

Actin susceptibility to thermal denaturation: Cryoprotectants did not affect $(p>0.05)$ the transition temperature of actin for fresh fillets (Figure 15). Cryoprotectants reduced $(p<0.05)$ actin susceptibility to thermal denaturation during frozen storage compared to the no-soak control but the effects were not 
significantly different from the water control. Water soaking decreased $(p<0.05)$ actin susceptibility to thermal denaturation when compared to the no-soak control for frozen fillets. This result may be due to water's dilution of solutes thereby lowering ionic strength. Phosphate reduced $(p<0.05)$ actin susceptibility to thermal denaturation compared to the no-soak treatment for fresh fillets, but the effect did not different $(p>0.05)$ from the water control (Table 6). Magnesium chloride enhanced $(p<0.05)$ actin susceptibility to heat denaturation in frozen fillets (Table 7). Hastings and coworkers (1985) indicated that actin quality, as measured by DSC, was unaffected by frozen storage. Park and Lanier (1993) reported decreased transition temperatures for actin due to frozen storage in both pre- and post-rigor ground beef. However, the effect of Polydextrose ${ }^{\circledR}$ and phosphate on the transition temperatures of actin was inconclusive. They noted that DSC was an insensitive method, since differences in transition temperatures or total enthalpies (area under curve) were small.

\section{Protease activity}

Gel weakening occurs in fish surimi during thermal processing (Lanier et al., 1981; Morrissey et al., 1993). When minces or surimi from these fish are heated slowly from 60 to $70^{\circ} \mathrm{C}$, a reduction in gel strength is observed. The primary cause for temperature-dependent gel weakening is believed to be certain enzymes that hydrolyze myofibrillar proteins, especially myosin, into small fragments. Recent studies demonstrated that capthepsins $B$ and $L$ are responsible for gel softening of fish surimi prepared from Pacific whiting and mackerel (An et al., 1994b; Jiang et al., 1994, 1996, 1997) Cathepsin B and L 
hydrolyze myofibrillar proteins at $\mathrm{pH}$ 6.5-7.5, supporting their involvement in gel weakening of some fish surimi (Jiang et al., 1997). In the present study, fresh samples possessed an initial proteolytic activity of 0.05 . Water, cryoprotectants, phosphate and magnesium chloride did not affect $(p>0.05)$ proteolytic activity (Figure 16 and Tables 6 and 7). Frozen storage may cause denaturation of some proteolytic enzymes reducing their activity following storage to the point that treatment effects were not discernable.

\section{Muscle color}

For fresh fillets soaked in sucrose/sorbitol and sodium lactate solutions, higher $L^{*}$ values $(p<0.05)$ were observed compared to water-soaked fillets (Figure 17). $L^{*}$ value decreased $(p<0.05)$ following frozen storage in the no-soak treatment (Table 1). Frozen fillets soaked in cryoprotectant solution had lower $(p<0.05) L^{*}$ values than those soaked in water, but the effects were not difference ( $p>0.05)$ from the no-soak treatment. Simpson and coworkers (1994) reported significantly lower whiteness value in 6-m frozen stabilized Pacific whiting mince; they suggested that this response was due to denaturation of the heme pigments. Conflicting results have been reported in salmon mince, that became lighter, more yellow, and less red during frozen storage (Hansen et al., 1990). According to Anderson and Steinsholt (1992), frozen storage between -13 and $-35^{\circ} \mathrm{C}$ significantly increased color retention. Fish species and processing condition differences may account for these conflicting results. Fresh fillets soaked in cryoprotectants had lower $\mathrm{a}^{*}$ (less redness) and $\mathrm{b}^{*}$ (less yellowness) values than the water control (Figures 18 and 19). Frozen storage decreased 
$(p<0.05) a^{*}$, but did not affect $(p>0.05) b^{*}$ values (Table 1). Sucrose/sorbitol elicited the lowest $b^{*}$ value in fresh and frozen samples $(p<0.05)$. The amount of water in fillets following thawing may influence the scattering of light.

Phosphate decreased $(p<0.05) L^{*}$ value and increased, although not significantly, $b^{*}$ value in fresh and frozen samples (Table 8 ). Phosphate effects may be due to increased water holding capacity as $\mathrm{pH}$ increased. When moisture is bound more tightly by myofibrillar proteins, less moisture is expressed on the meat surface. This effect results in less reflected light from the meat surface, yielding the dark appearance (Faustman, 1994). Magnesium chloride did not affect $(p>0.05)$ muscle color for fresh and frozen fillets (Table 9).

\section{Brine uptake}

Frozen storage increased $(p<0.05)$ fillet weight loss after brining may be associated with disintegration of muscle integrity (Table 1). Since freezing rate in the present study was slow, formation of large ice crystals intercellularly damaged cells and thus, disrupted muscle structure. Protein denaturation by slow freezing has been reported (Grujic et al., 1993). This damage may enhance the movement of water from tissues to the surrounding brine solution as a result of the salt concentration gradient.

The high brine uptake in the fresh, no-soaked fillets was because those fillets had never been soaked in water or cryoprotectant solution prior to brining (Figure 20). Increased fillet water uptake of the water control during cryoprotectant soaking increased fillet weight loss of fresh samples during brining due to water migration from fillets. Perhaps water loss from fillets during 
cryoprotectant soaking explains fillet weight gain of fresh samples during brining. Phosphate and magnesium chloride did not affect brine uptake $(p>0.05)$ in fresh and frozen fillets (Tables 10 and 11).

\section{Cook yield}

Mince cook yield: Frozen storage lowered mince cook yield, although not significantly (Table 1), due to decreased solubility of myofibrillar proteins, especially myosin. Imbalance between myosin and actin concentration decreases gel-forming ability (Foegeding et al., 1996). In gelation, myosin is an important component with respect to gel matrix formation. Actin assists in this process by forming F-actomyosin that, in turn, interacts with free myosin. In addition, conformational change of proteins due to structure unfolding promoted protein-protein interactions and reduced protein-water interactions. This change contributed to the loss of water holding capacity that decreased cook yield.

Cryoprotectants, phosphate, and magnesium chloride did not affect ( $p>0.05)$ mince cook yield in fresh and frozen groups (Figure 21 and Tables 10 and 11).

Fillet cook yield: Fresh unsoaked fillets had the highest cook yield $(p<0.05)$ compared to soaked treatments (Figure 22). This effect may be associated with a decreased amount of water/solution to lose during thermal processing. Cryoprotectant treatments produced higher cook yields than the water control for the fresh group $(p<0.05)$. Frozen storage lowered cook yield of smoked products produced from the no-soak treatment, although not significantly (Table 1). Cryoprotectants increased $(p<0.05)$ cook yield of frozen fillets 
compared to the no-soak and water controls. The ability of sucrose/sorbitol and sodium lactate to preserve protein native structure explains these results. Borderias and coworkers (1982) observed cooking drip during frozen storage of trout fillets and mince. They indicated that this drip be connected to the slight decrease in protein solubility. Increased myofibrillar protein solubility due to cryoprotectants corresponded to increased cook yield in the present study. Phosphate and magnesium chloride did not affect $(p>0.05)$ cook yield of smoked trout fillets (Tables 10 and 11).

\section{Cooked pH}

Cooked $\mathrm{pH}$ values were higher than raw $\mathrm{pH}$ for all treatments. Sodium lactate caused higher cooked $\mathrm{pH}$ values $(\mathrm{p}<0.05)$ than the no-soak and water control treatments for fresh and frozen samples (Figure 23). Phosphate increased $(p<0.05)$ cooked $\mathrm{pH}$ compared to the no-phosphate control (Table 10). However, it was not different $(p>0.05)$ from the no-soak control of fresh and frozen fillets. Fillets soaked in magnesium chloride solution produced the lowest cooked $\mathrm{pH}$ when compared to both fresh fillet controls (Table $11 ; \mathrm{p}<0.05$ ). Pojedinec (1999) reported that magnesium chloride decreased cooked $\mathrm{pH}$ compared to products without magnesium chloride. Magnesium chloride did not affect $(p>0.05) \mathrm{pH}$ of smoked products produced from frozen fillets.

\section{Total and water-phase salt content}

Increasing total and water-phase salt content in frozen fillets (Table 1; $p<0.05)$ was associated with the dehydrating effect of the brine. Tissue damage and reduced muscle integrity were responsible for the increased total and water- 
phase salt content. Cryoprotectants, phosphate, and magnesium chloride did not affect ( $p>0.05)$ total and water-phase salt content (Figures 24 and 25, and Tables 10 and 11).

\section{Texture}

Hardness: For fresh fillets, the no-soak treatment produced the highest hardness value (Figure 26). Sodium lactate decreased $(p<0.05)$ hardness compared to the no soak. Sucrose/sorbitol did not affect $(p>0.05)$ hardness of cooked mince produced from fresh fillets when compared to the no-soak and water control treatments. Frozen storage decreased $(p<0.05)$ hardness in the no-soak control (Table 1), and cryoprotectants increased $(p<0.05)$ hardness compared to controls. Dias and coworkers (1994) reported a significant increase in hardness of frozen black and scabbard fish subsequently thawed and cooked. Phosphate and magnesium chloride did not affect ( $p>0.05)$ hardness (Tables 12 and 13).

Cohesiveness: Cohesiveness of cooked mince derived from fresh fish was lower $(p<0.05)$ for sucrose/sorbitol and sodium lactate (Figure 27). Frozen storage decreased $(p<0.05)$ cohesiveness of the no-soak treatment $($ Table 1$)$. For frozen raw material, cohesiveness was improved by cryoprotectants compared to controls, and values were similar to fresh, no-soaked fillet values. Borderias and coworkers (1982) observed decreased firmness of trout mince up to $30-75 \mathrm{~d}$ of frozen storage. They explained that this decreased firmness was due to the loss of cohesion between mince particles; they indicated that it was not directly related to decreased protein solubility but might be more closely 
related to pre-rigor events and the onset of rigor mortis. Relative to frozen storage effects on hardness and cohesiveness and cryoprotectant effects in the present study, values are positively related to amount of soluble myofibrillar proteins. Cryoprotection by sucrose/sorbitol improved gel forming ability and texture development (Park and Lanier, 1987; Park et al., 1987a, 1988).

Phosphate and magnesium chloride did not affect cohesiveness of cooked mince in fresh and frozen samples compared to the no-soak control (Tables 12 and 13). Even though these salts caused some change in physiochemical attributes of proteins, the magnitude of the change was not large enough to cause differences in texture development.

Shear force: Frozen storage decreased $(p<0.05)$ shear force compared to products derived from fresh fillets (Table 1). Similar results have been reported in a preliminary study. Decreased shear force may be due to decreased myofibrillar protein solubility, especially myosin. No differences in fillet shear force were found for cryoprotectants, phosphate and magnesium chloride (Figure 28 and Tables 12 and 13).

\section{Proximate composition}

Composition of brined fillets was determined after brining. Cooked proximate composition was determined from smoked products.

Frozen storage did not affect ( $p>0.05)$ brined and cooked moisture, fat and protein, but increased $(p<0.05)$ brined ash $(2.19$ vs $2.08 \%)$ and cooked ash $(3.23$ vs $3.02 \%$ ) compared to fresh counterparts (Table 1). Increased brined and 
cooked ash corresponded to increased total and water-phase salt content in smoked products.

Brined fat of the sodium lactate treated fresh fillets was greater $(p<0.05)$ than sucrose/sorbitol (Table 14). Sucrose/sorbitol increased brined fillet protein, while sodium lactate had the lowest brined fillet protein for fresh fillets. No difference $(p>0.05)$ in brined fillet fat and protein was observed among treatments in the frozen group.

Cooked moisture and fat of fresh fillets was lowest $(p<0.05)$ for sucrose/sorbitol compared to both controls (Table 15). No difference in cooked moisture of frozen samples was observed as a function of cryoprotectant $(p>0.05)$. Cooked fat of frozen fillets was greatest $(p<0.05)$ in the sodium lactate treatment. Cryoprotectants increased $(p<0.05)$ cooked protein of smoked fillets derived from the frozen group compared to the water control; cryoprotectant treatments were not different $(p>0.05)$ from the no-soak control.

Addition of phosphate (Tables 16 and 17) or magnesium chloride (Tables

18 and 19) in water and cryoprotectant did not affect proximate composition of brined and cooked fillets for fresh and frozen groups.

\section{CONCLUSIONS}

Frozen storage at $-20^{\circ} \mathrm{C}$ for $90 \mathrm{~d}$ decreased total protein and myofibrillar protein solubility, and increased protein surface hydrophobicity, total, free and disulfide sulfhydryl content, and myosin susceptibility to thermal denaturation. Among these changes, surface hydrophobicity drastically increased. 
Cryoprotectants minimized the negative effects of frozen storage on physiochemical traits of myofibrillar proteins. Sucrose/sorbitol and sodium lactate increased total protein and myofibrillar protein solubility and decreased surface hydrophobicity, total, free and disulfide sulfhydryl content, and myosin susceptibility to thermal denaturation compared to the no-soak control. There was no difference in total protein solubility and actin susceptibility to thermal denaturation between cryoprotectants and the water control. Phosphate enhanced the cryoprotective effect on myofibrillar protein solubility, surface hydrophobicity, and myosin susceptibility to thermal denaturation. The addition of magnesium chloride tended to accelerate protein denaturation during frozen storage by decreasing myosin solubility and increasing disulfide sulfhydryl content.

$L^{*}, a^{*}$, and $b^{*}$ values of fillets, treated with cryoprotectants and frozen, were lower than untreated and water-soaked fillets. Cryoprotection in frozen fillets preserved quality of frozen trout fillets that were subsequently used for smoked trout production. Sucrose/sorbitol and sodium lactate improved hardness and cohesiveness of cooked mince. These cryoprotectants increased cook yield, $\mathrm{pH}$, and fat content of smoked fillets compared to the opposite effects for the no-soak and water controls after frozen storage. Frozen storage increased fillet weight loss after brining, total and water-phase salt content, brined and cooked ash, and decreased fillet shear force. 
Sucrose/sorbitol provided more effective cryoprotection than sodium lactate in preservation of protein structure and in improvement smoked product quality. 


\section{REFERENCES}

An,H., Seymour,T.A., Wu,J., and Morrissey,M.T. 1994a. Assay systems and characterization of Pacific whiting (Merluccius productus) protease. J. Food Sci. 59(2): 277-281.

An,H., Weerasinghe,V., Seymour,T.A., and Morrissey,M.T. 1994b. Cathepsin degradation of Pacific whiting surimi proteins. J. Food Sci. 59(5): 1013-1017, 1033.

Andersen,U.B. and Steinsholt,K. 1992. Deep frozen salmon: Differences in quality after storage at different temperatures following different storage periods. Norw. J. Agric. Sci. 6: 211-215.

Ang,J.F. and Hultin,H.O. 1989. Denaturation of cod myosin during freezing after modification with formaldehyde. J. Food Sci. 54(4): 814-818.

AOAC. 1990. Official Methods of Analysis. $15^{\text {th }}$ ed. Washington, DC:Association of Official Analytical Chemists.

Back,J.F., Oakenfull,D., and Smith,M.B. 1979. Increased thermal stability of proteins in the presence of sugars and polyols. Biochemistry. 18(23): 5191-5196.

Behringer,M.P. 1973. Techniques and materials in biology. New York:McGrawHill Co. 600 p.

Beveridge,T., Toma,S.J., and Nakai,S. 1974. Determination of SH- and SSgroups in some food proteins using Ellman's reagent. J. Food Sci. 39(1): 49-51.

Borderias,A.J., Moral,A., and Tejada,M. 1982. Stability of whole, filleted, and minced trout (Salmo irideus Gibb) during frozen storage. J. Food Biochem. 6(3): 187-195.

Bourne,M.C. 1978. Texture profile analysis. Food Technology. 32(7): 62-66, 72.

Buttkus,H. 1970. Accelerated denaturation of myosin in frozen solution. J. Food Sci. 35(5): 558-562.

Careche,M., del Mazo,M.L., Torrejon,P., and Tejada,M. 1998. Importance of frozen storage temperature in the type of aggregation of myofibrillar proteins in cod (Gadus morhua) fillets. J. Agric. Food Chem. 46(4): 1539-1546.

del Mazo,M.L., Torrejon,P., Careche,M., and Tejada,M. 1999. Characteristics of the salt-soluble fraction of hake (Merluccius merluccius) fillets stored at -20 and $30^{\circ} \mathrm{C}$. J. Agric. Food Chem. 47(4): 1372-1377. 
Dias,J., Nunes,M.L., and Mendes,R. 1994. Effect of frozen storage on the chemical and physical properties of black and silver scabbardfish. J. Sci. Food Agric. 66(3): 327-335.

Dunajski,E. 1979. Texture of fish muscle. J. Texture Studies. 10(4): 301-317.

Faustman,C. 1994. Postmorten changes in muscle foods. In: D.M.Kinsman, A.W.Kotula and B.C.Breidenstein, editors. Muscle Foods: Meat Poultry and Seafood Technology. New York:Chapman \& Hall Inc. p. 74.

Federal Register. 1995. Procedures for the safe and sanitary processing and importing of fish and fishery products. Federal Register. 60(242): 61561-61563.

Findley,C.J. and Barbut,S. 1992. A repsponse surface investigation of the effects of sodium of chloride and tripolyphosphate on the thermal properties of beef muscle. Meat Sci. 31(2): 155-164.

Foegeding,E.A., Lanier,T.C., and Hultin,H.O. 1996. Characteristics of edible muscle tissues. In: O.Fennema, editor. Food Chemistry. New York:Marcel Dekker, Inc. p. 915.

Franks,F. 1995. Protein destabilization at low temperature. Adv. Prot. Chem. 46: 105-139.

Fritz,J.D., Swart,D.R., and Greaser,M.L. 1989. Factors affecting polyacrylamide gel electrophoresis and electroblotting of high-molecular-weight myofibrillar proteins. Anal. Biochem. 180: 205-210.

Fukumi,T., Tamoto,K., and Hidesato,T. 1965. Mon. Rep. Hokkaido Municipal Fish Exp. Stn. 22: 30. mentioned in Park,J.W., Lanier,T.C., Keeton,J.T., and Hamann,D.D. 1987. Use of cryoprotectants to stabilize functional properties of prerigor salted beef during frozen storage. J. Food Sci. 52(3): 537-542.

Gornall,A.G., Bardawill,C.T., and David,M.M. 1949. Determination of serum proteins by means of the biuret reaction. J. Biol. Chem. 177(2): 751-766.

Greaser,M.L., Yates,L.D., Krzywicki,K., and Roelke,D.L. 1983. Electrophoretic methods for the separation and identification of muscle proteins. In: Proceeding of the $36^{\text {th }}$ Annual Recip. Meat Conf. Chicago:National Livestock and Meat Board. p. 87.

Grujic,R., Petrovic,L., Pikula,B., and Amidzic,L. 1993. Definition of the optimum freezing rate -1 . Investigation of structure and ultrastructure of beef $M$. longgissimus dorsi frozen at different freezing rates. Meat Sci. 33(3): 301-318.

Hansen,G.T., Nyvold,T.E., Solberg,T., and Ofstad,R. 1990. Frozen storage of various semi-processed products of Atlantic salmon. Science et Technique du froid. 211-217. 
Hastings,R.J., Rodger,G.W., Park,R., Matthews,A.D., and Anderson,E.M. 1985. Differential scanning calorimetry of fish muscle: The effect of processing and species variation. J. Food Sci. 50(2): 503-506, 510.

Heinitz,M.L. and Johnson,J.M. 1998. The incidence of Listeria spp., Salmonella spp., and Clostridium botulinum in smoked fish and shellfish. J. Food Prot. 61(3): 318-323.

Hsu,C.K., Kolbe,E., Morrissey,M.T., and Chung,Y.C. 1993. Protein denaturation of frozen Pacific whiting (Merluccius productus) fillets. J. Food Sci. 58(5): 10551056, 1075.

Hurling,R. and Mcarthur,H. 1996. Thawing, refreezing and frozen storage effects on muscle functionality and sensory attributes of frozen cod (Gadus morhua). J. Food Sci. 61(6): 1289-1296.

Jiang,S.T., Lan,C.C., and Tsao,C.Y. 1986. New approach to improve the quality of minced fish products from freeze-thawed cod and mackerel. J. Food Sci. 51(2): 310-312, 351.

Jiang,S.T., Lee,J.J., and Chen,H.C. 1994. Purification and characterization of cathepsin B from ordinary muscle of mackerel (Scomber australasicus). J. Agric. Food Chem. 42(5): 1073-1079.

Jiang,S.T., Lee,J.J., and Chen,H.C. 1996. Proteolysis of actomyosin by cathepsin B, L, L-like and X from mackerel (Scomber australasicus). J. Agric. Food Chem. 44(3): 769-773.

Jiang,S.T., Lee,B.L., Tsao,C.Y., and Lee,J.J. 1997. Mackerel cathepsin B and L effects on thermal degradation of surimi. J. Food Sci. 62(2): 310-315.

Kato,A. and Nakai,S. 1980. Hydrophobicity determined by a fluorescent probe method and its correlation with surface properties of proteins. Biochimica et Biophysica Acta. 624(1): 13-20.

Kenney,P.B., Kastner,C.L., and Kropf,D.H. 1992. Muscle washing and raw material source affect quality and physicochemical properties of low-salt, low-fat, resutructured beef. J. Food Sci. 57(3): 545-550, 589.

Lanier,T.C., Lin,T.S., Hamann,D.D., and Thomas,F.B. 1981. Effects of alkaline protease in minced fish on texture of heat processed gels. J. Food Sci. 46(6): 1643-1645.

Lee,C.M. 1984. Surimi process technology. Food Technology. 38(12): 69-80.

Lin,T.M. and Park,J.W. 1998. Solubility of salmon myosin as affected by conformational changes at various ionic strengths and pH. J. Food Sci. 63(2): 215-218. 
Lindsay,R.C. 1996. Food additives. In: O.Fennema, editor. Food Chemistry. New York:Marcel Dekker, Inc. p. 778-785.

MacDonald,G.A. and Lanier,T.C. 1994. Actomyosin stabilization to freeze-thaw and heat denaturation by lactate salts. J. Food Sci. 59(1): 101-105.

MacDonald,G.A. and Lanier,T.C. 1997. Cryoprotectants for improving frozenfood quality. In: M.C.Erickson and Y.C.Hung, editors. Quality in Frozen Food. New York:Chapman \& Hall. p. 197-201.

MacDonald,G.A., Lanier,T.C., Swaisgood,H.E., and Hamann,D.D. 1996. Mechanism for stabilization of actomy0sin by sodium lactate. J. Agric. Food Chem. 44(1): 106-112.

Mahon,J.H. and Schneider,C.G. 1964. Minimizing freezing damage and thawing drip in fish fillets. Food Technology. 18(12): 117-118.

Miller,A.J., Ackerman,S.A., and Palumbo,S.A. 1980. Effects of frozen storage on functionality of meat for processing. J. Food Sci. 45(6): 1466-1471.

Moral,A., Tejada,M., and Borderias,A.J. 1986. Stability of frozen trout I. Treated and untreated minces stored at $-12,-18$, and $-24^{\circ} \mathrm{C}$. J. Food Biochem. 10(1): 3746.

Morrissey,M.T., Wu,J.W., Lin,D., and An,H. 1993. Protease inhibitor effects on torsion measurements and autolysis of Pacific whiting surimi. J. Food Sci. 58(5): 1050-1054.

Owasu-Ansah,A.J. and Hultin,H.O. 1986. Chemical and physical changes in red hake fillets during frozen storage. J. Food Sci. 51(6): 1402-1406.

Paredi,M.E., Mattio,N.A., and Crupkin,M. 1996. Biochemical properties of actomyosin and expressible moisture of frozen stored striated adductor muscle of Aulacomya ater ater (Milina): Effects of polyphosphates. J. Agric. Food Chem., 44(10): 3108-3112.

Park,J.W. and Lanier,T.C. 1987. Combined effects of phosphates and sugar or polyol on protein stabilization of fish myofibrils. J. Food Sci. 52(6): 1509-1513.

Park,J.W. and Lanier,T.C. 1989. Scanning calorimetric behavior of tilapia myosin and actin due to processing of muscle and protein purification. J. Food Sci. 54(1): 49-51.

Park,J.W., Lanier,T.C., and Green,D.P. 1988. Cryoprotective effects of sugar, polyols, and/or phosphates on Alaska pollock surimi. J. Food Sci. 53(1): 1-3. 
Park,J.W., Lanier,T.C., and Pilkington,D.H. 1993. Cryostabilization of functional properties of pre-rigor and post-rigor beef by dextrose polymer and/or phosphates. J. Food Sci. 58(3): 467-472.

Park,J.W., Lanier,T.C., Keeton,J.T., and Hamann,D.D. 1987a. Use of cryoprotectants to stabilize functional properties of prerigor salted beef during frozen storage. J. Food Sci. 52(3): 537-542.

Park,J.W., Lanier,T.C., Swaisgood,H.E., Hamann,D.D., and Keeton,J.T. 1987b. Effects of cryoprotectants in minimizing physicochemical changes of bovine natural actomyosin during frozen storage. J. Food Biochem. 11(2): 143-161.

Pigott,R.S., Kenney,P.B., Slider,S., and Head,M.K. 2000. Formulation protocol and dicationic salts effect protein functionality on model beef batters. J. Food Sci. 65(7): 1151-1154.

Pojedinec,S.L. 1999. Effect of maturity and divalent salts on quality of low-fat, low-sodium restructured beef. Master Thesis, West Virginia University. 95 p.

Privalov,R.L., Griko,Y.V., Venyaminov,Y.S., and Kutyshenko,V.P. 1986. Cold denaturation of myoglobin. J. Mol. Biol. 190(3): 487-498.

Sarkar,N.K. 1950. The effect of ions and ATP on myosin and actomyosin. Enzymologia. 14(4): 237-245.

SAS Institute Inc. 1989. SAS users guide: Basics version 6.06. Statistical Analysis System Institute Inc. Cary, NC.

Sikorski,Z.E., Olley,J., and Kostuch,S. 1976. Protein changes in frozen fish. Crit. Rev. Food Sci. Nutr. 8(1): 97-129.

Simpson,R., Morrissey,M.T., Kolbe,E., Lanier,T.C., and MacDonald,G.A. 1994. Effects of varying sucrose concentrations in Pacific whiting (Merluccius productus) stabilized mince used for surimi production. J. Aqua. Food Prod. Tech. 3(4): 41-52.

Srinivasan,S. and Xiong,Y.L. 1996. Gelation of beef heart surimi as affected by antioxidants. J. Food Sci. 61(4): 707-711.

Srinivasan,S. and Xiong,Y.L. 1997. Sulfhydryls in antioxidant-washed beef heart surimi. J. Muscle Foods. 8(3): 251-263.

Srinivasan,S., Xiong,Y.L., Blanchard,P., and Tidwell,J.H. 1997. Physicochemical changes in prawns (Machrobrachium rosenbergii) subjected to multiple freezethaw cycles. J. Food Sci. 62(1): 123-127. 
Tejada,M., Careche,M., Torrejon,P., del Mazo,M.L., Solas,M.T., Garcia,M.L., and Barba,C. 1996. Protein extracts and aggregates forming in minced cod (Gadus morhua) during frozen storage. J. Agric. Food Chem. 44(10): 3308-3314.

Trout,G.R. and Schmidt,G.R. 1983. Utilization of phosphate in meat products. In: Proceeding of the $36^{\text {th }}$ Annual Reciprocal Meat Conference. Chicago:National Livestock and Meat Board. p. 24-27.

Varunsatian,S., Watanabe,K., Hayakawa,S., and Nakamura,R. 1983. Effects of $\mathrm{Ca}^{++}, \mathrm{Mg}^{++}$and $\mathrm{Na}^{+}$on heat aggregation of whey protein concentrates. J. Food Sci. 48(1): 42-46, 70.

Wang,B., Xiong,Y.L., and Srinivasan,S. 1997. Chemical stability of antioxidantwashed beef heart surimi during frozen storage. J. Food Sci. 62(5): 939-945, 991.

Wright,D.J., Leach,I.B., and Wilding,P. 1977. Differential scanning calorimetric studies of muscle and its constituent proteins. J. Sci. Food Agric. 28(6): 557-564.

Zotos,A., Hole,M., and Smith,G. 1995. The effect of frozen storage of mackerel (Scomber scombrus) on its quality when hot-smoked. J. Sci. Food Agric. 67(1): 43-48. 
Figure 1. Mean $\mathrm{pH}$ water, $1 \%(\mathrm{w} / \mathrm{v})$ sodium lactate $(\mathrm{SL})$, and $8 \%(\mathrm{w} / \mathrm{v})$ sucrose/sorbitol $(1: 1 \mathrm{w} / \mathrm{w})$ solutions, alone or in combination with $0.5 \%$ $(\mathrm{w} / \mathrm{v})$ phosphates $\left(\mathrm{PO}_{4}\right)$ and/or $0.05 \%(\mathrm{w} / \mathrm{v})$ magnesium chloride $\left(\mathrm{MgCl}_{2}\right)$. 


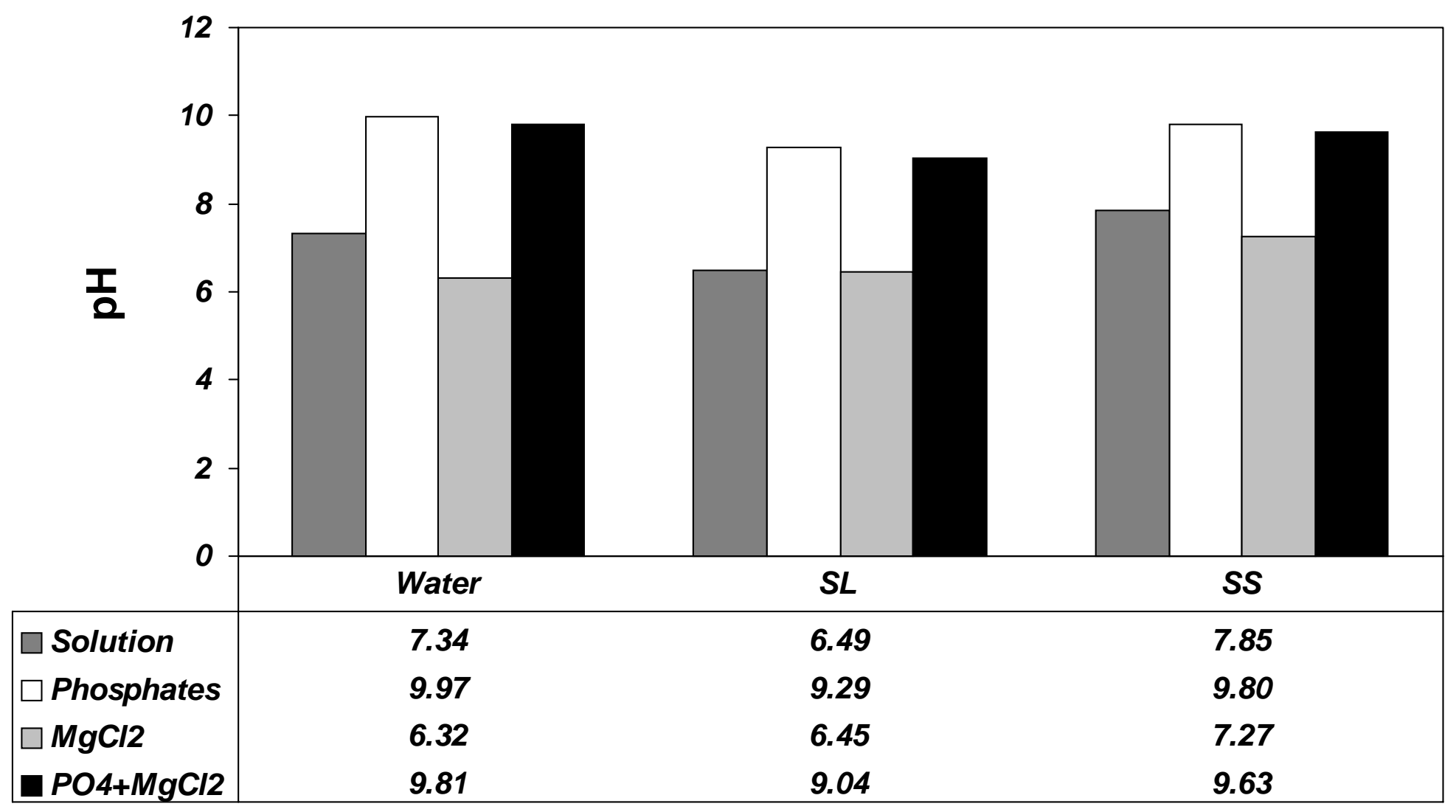




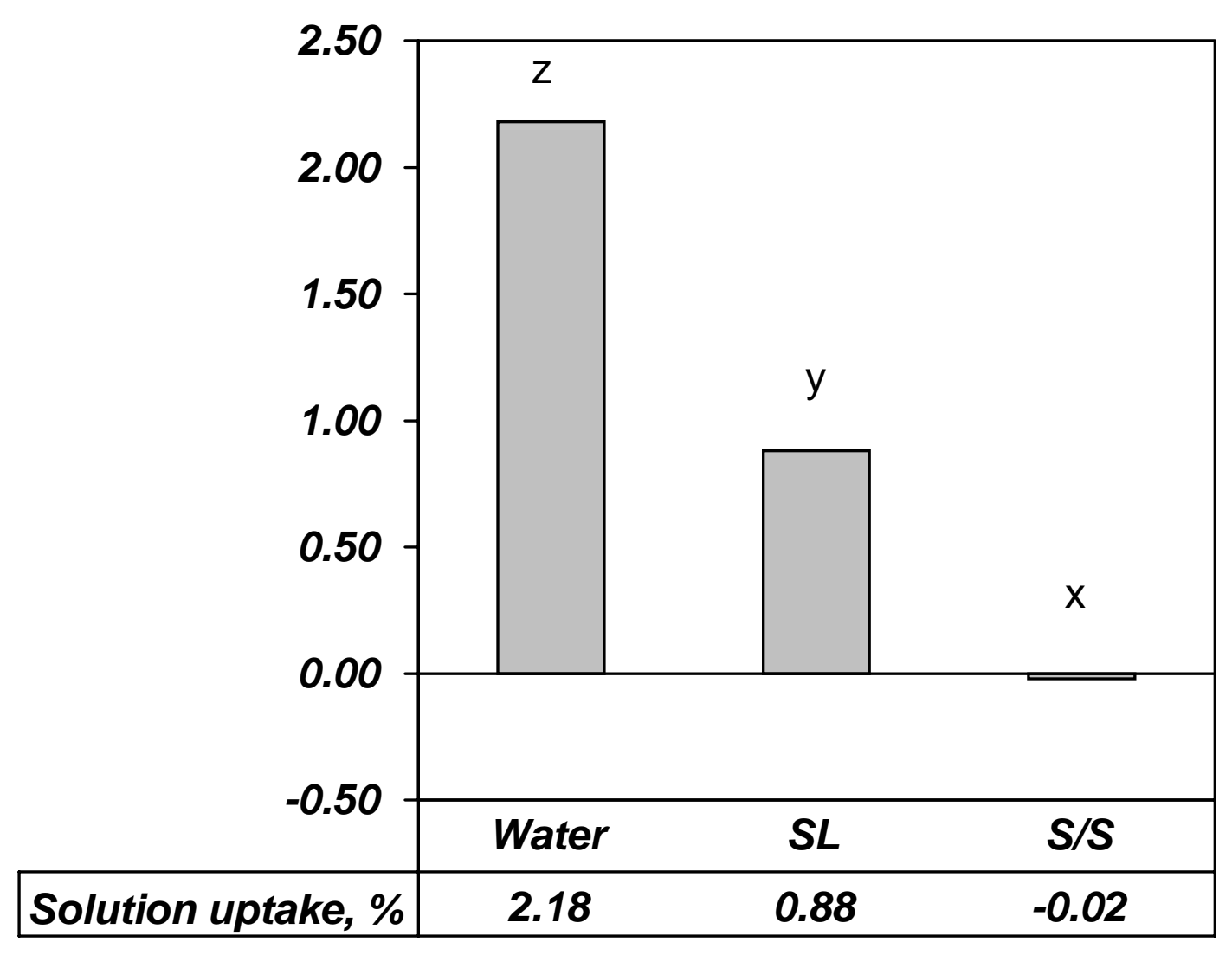

Figure 2. Effect of cryoprotectant on solution uptake.

$S L=1 \%(w / v)$ sodium lactate solution

$\mathrm{S} / \mathrm{S}=8 \%(\mathrm{w} / \mathrm{v})$ sucrose/sorbitol $(1: 1 \mathrm{w} / \mathrm{w})$ solution

${ }^{x y z}$ Means with different superscripts are different $(p<0.05)$. 


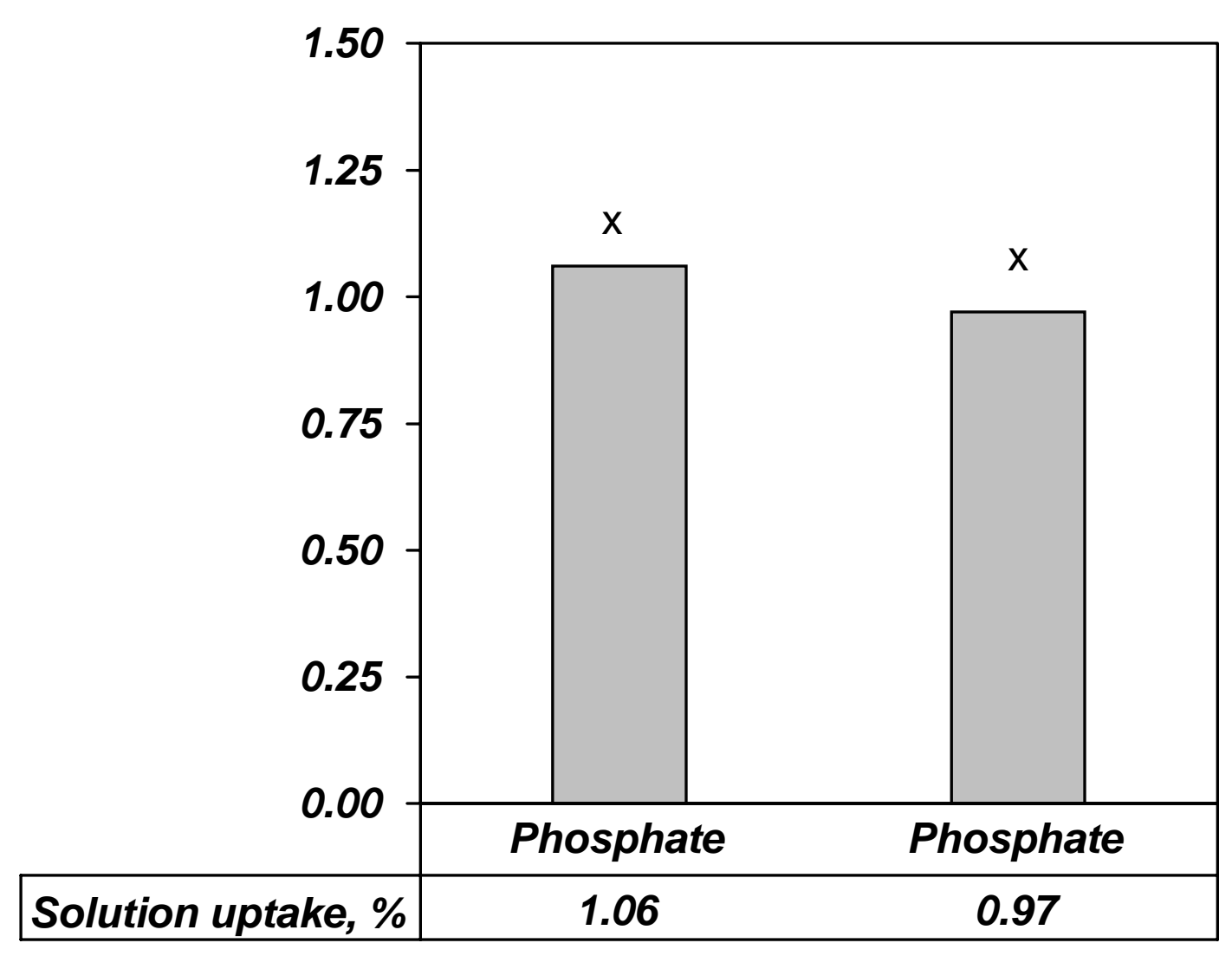

Figure 3. Effect of $0.5 \%(\mathrm{w} / \mathrm{v})$ phosphate on solution uptake.

${ }^{x y}$ Means with different superscripts are different $(p<0.05)$. 


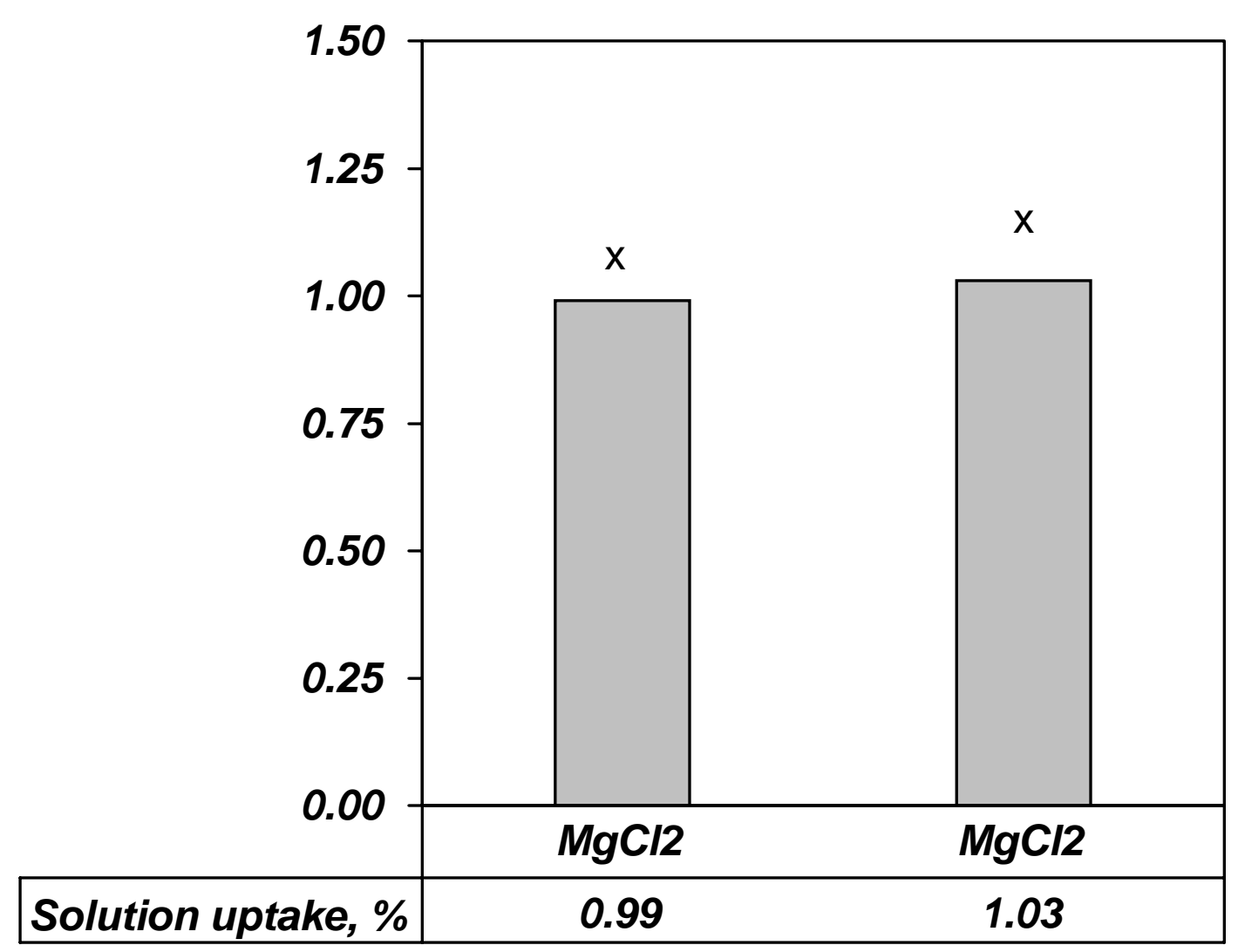

Figure 4. Effect of $0.05 \%(\mathrm{w} / \mathrm{v})$ magnesium chloride $\left(\mathrm{MgCl}_{2}\right)$ on solution uptake.

${ }^{x y}$ Means with different superscripts are different $(p<0.05)$. 


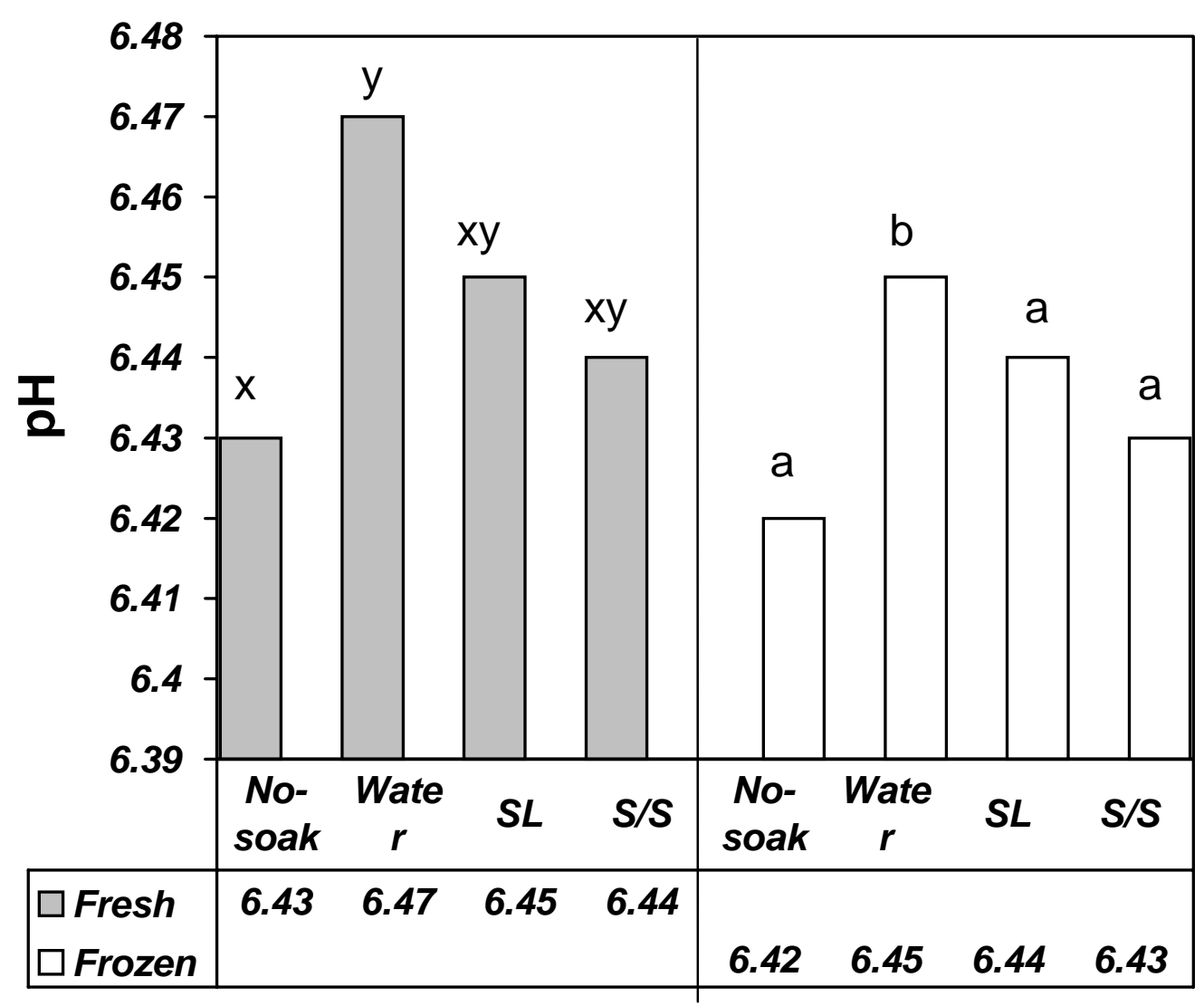

Figure 5. Effect of cryoprotectant on fillet $\mathrm{pH}$.

No-soak= Fillets without soaking treatment

Water= Fillets soaked in water

$\mathrm{SL}=1 \%(\mathrm{w} / \mathrm{v})$ sodium lactate solution

$\mathrm{S} / \mathrm{S}=8 \%(\mathrm{w} / \mathrm{v})$ sucrose/sorbitol $(1: 1 \mathrm{w} / \mathrm{w})$ solution

${ }^{x y z}$ Means within fresh condition with different superscripts are different $(p<0.05)$.

${ }^{a b c}$ Means within frozen condition with different superscripts are different $(p<0.05)$. 


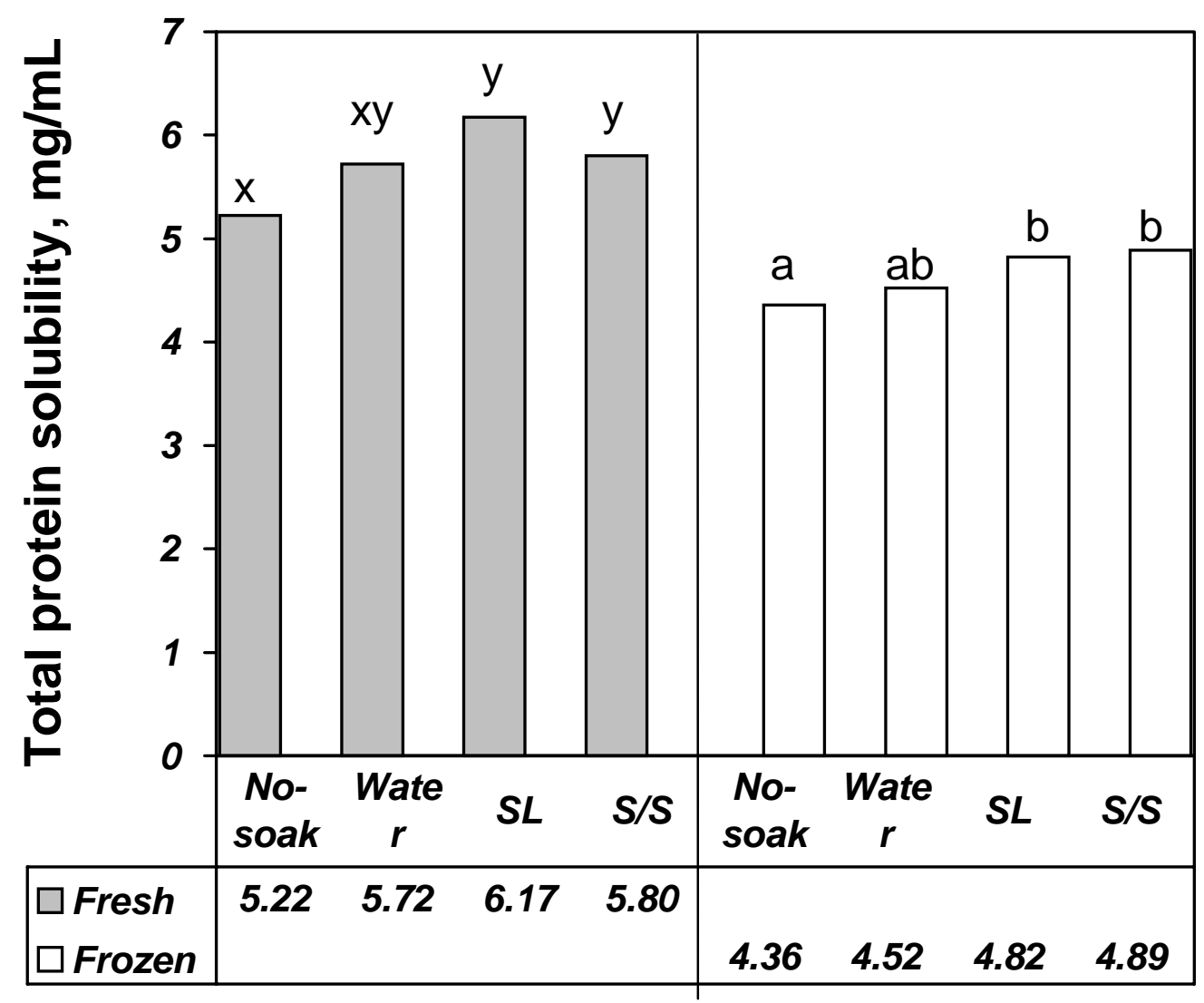

Figure 6. Effect of cryoprotectant on total protein solubility.

No-soak= Fillets without soaking treatment

Water= Fillets soaked in water

$\mathrm{SL}=1 \%(\mathrm{w} / \mathrm{v})$ sodium lactate solution

$\mathrm{S} / \mathrm{S}=8 \%(\mathrm{w} / \mathrm{v})$ sucrose/sorbitol $(1: 1 \mathrm{w} / \mathrm{w})$ solution

${ }^{x y z}$ Means within fresh condition with different superscripts are different $(p<0.05)$.

${ }^{a b c}$ Means within frozen condition with different superscripts are different $(p<0.05)$. 


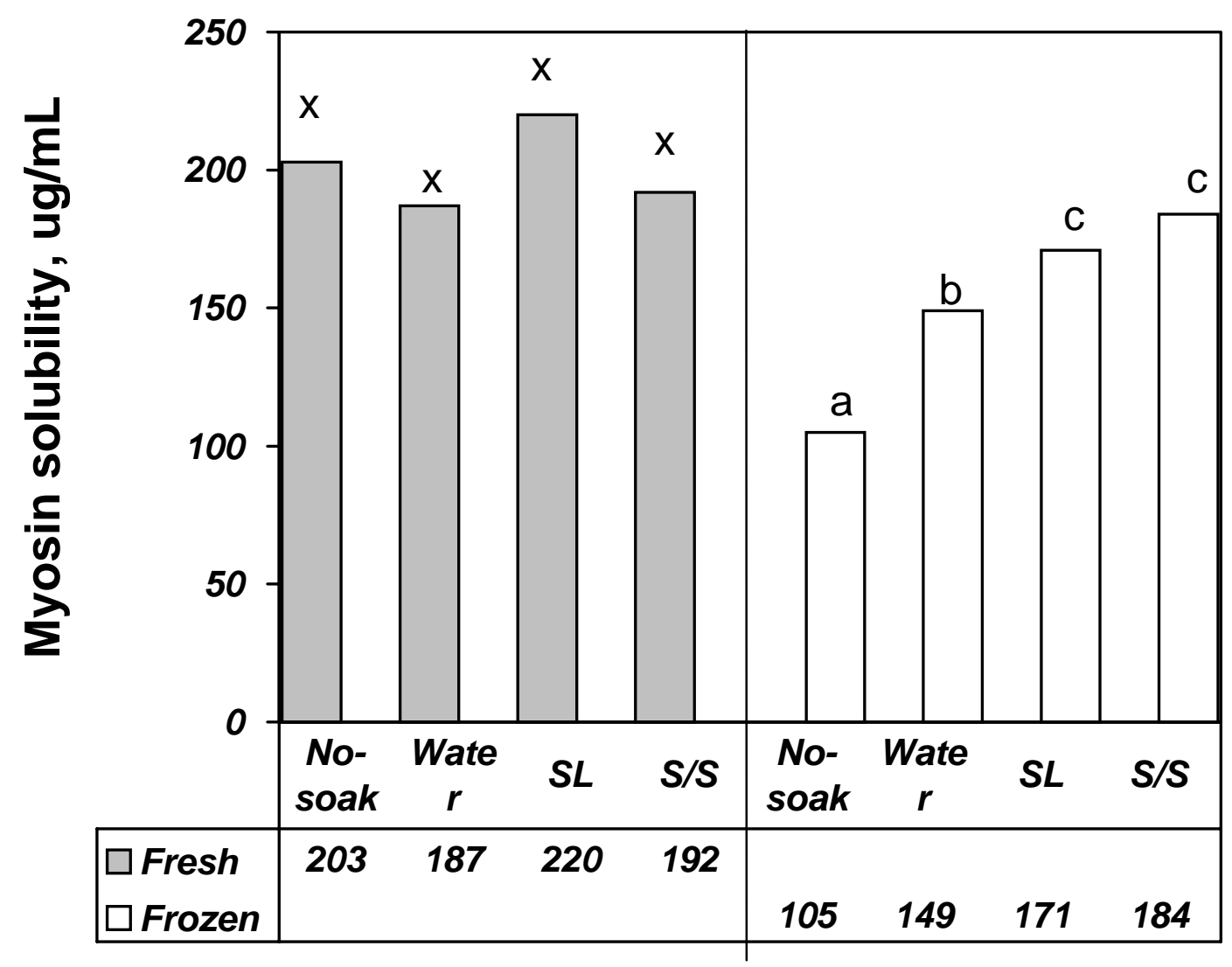

Figure 7. Effect of cryoprotectant on myosin solubility.

No-soak= Fillets without soaking treatment

Water= Fillets soaked in water

$\mathrm{SL}=1 \%(\mathrm{w} / \mathrm{v})$ sodium lactate solution

$S / S=8 \%(w / v)$ sucrose/sorbitol $(1: 1 \mathrm{w} / \mathrm{w})$ solution

${ }^{x y z}$ Means within fresh condition with different superscripts are different $(p<0.05)$.

${ }^{a b c}$ Means within frozen condition with different superscripts are different $(p<0.05)$. 


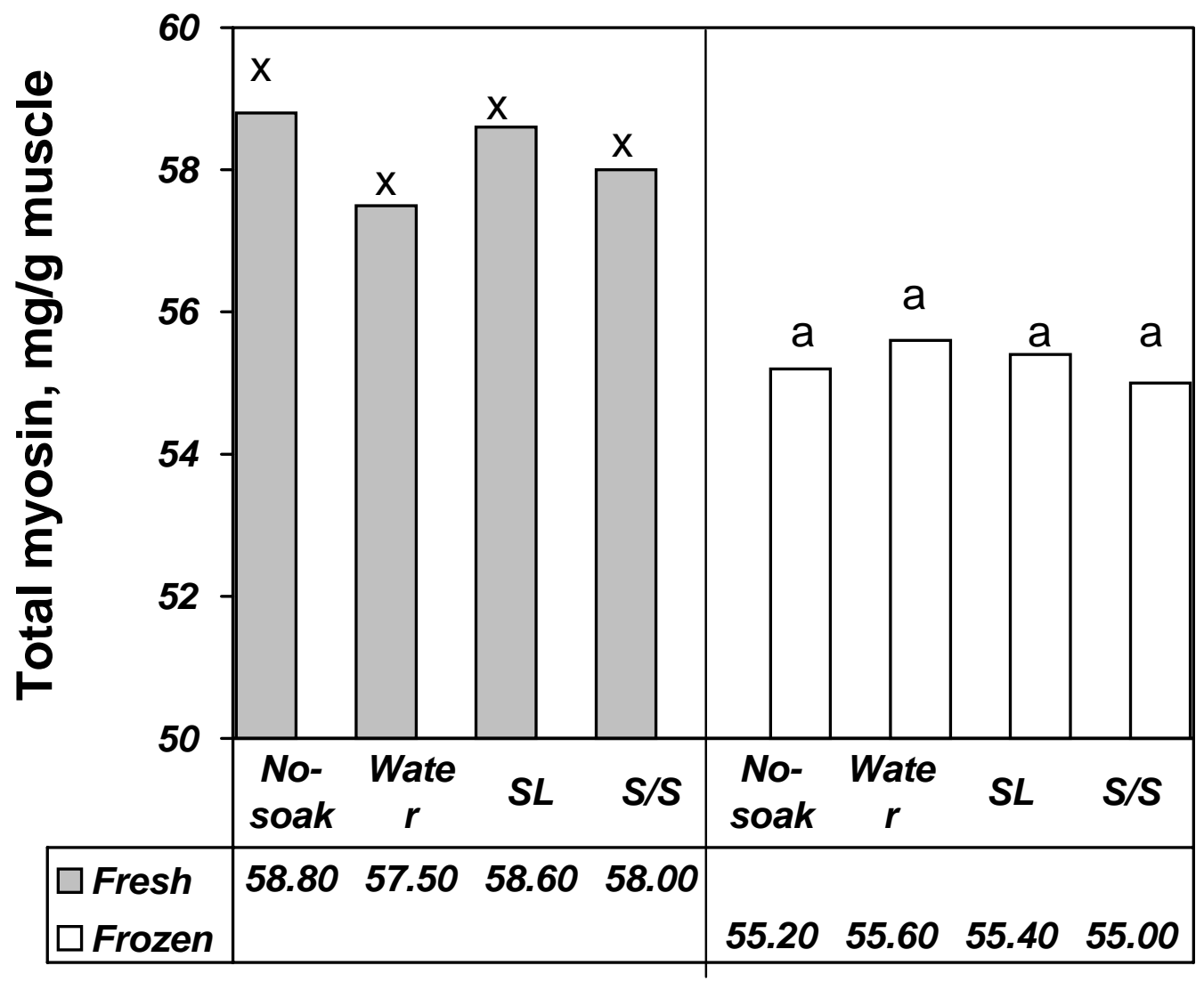

Figure 8. Effect of cryoprotectant on total myosin.

No-soak= Fillets without soaking treatment

Water= Fillets soaked in water

$\mathrm{SL}=1 \%(\mathrm{w} / \mathrm{v})$ sodium lactate solution

$\mathrm{S} / \mathrm{S}=8 \%(\mathrm{w} / \mathrm{v})$ sucrose/sorbitol $(1: 1 \mathrm{w} / \mathrm{w})$ solution

${ }^{x y z}$ Means within fresh condition with different superscripts are different $(p<0.05)$.

${ }^{a b c}$ Means within frozen condition with different superscripts are different $(p<0.05)$. 


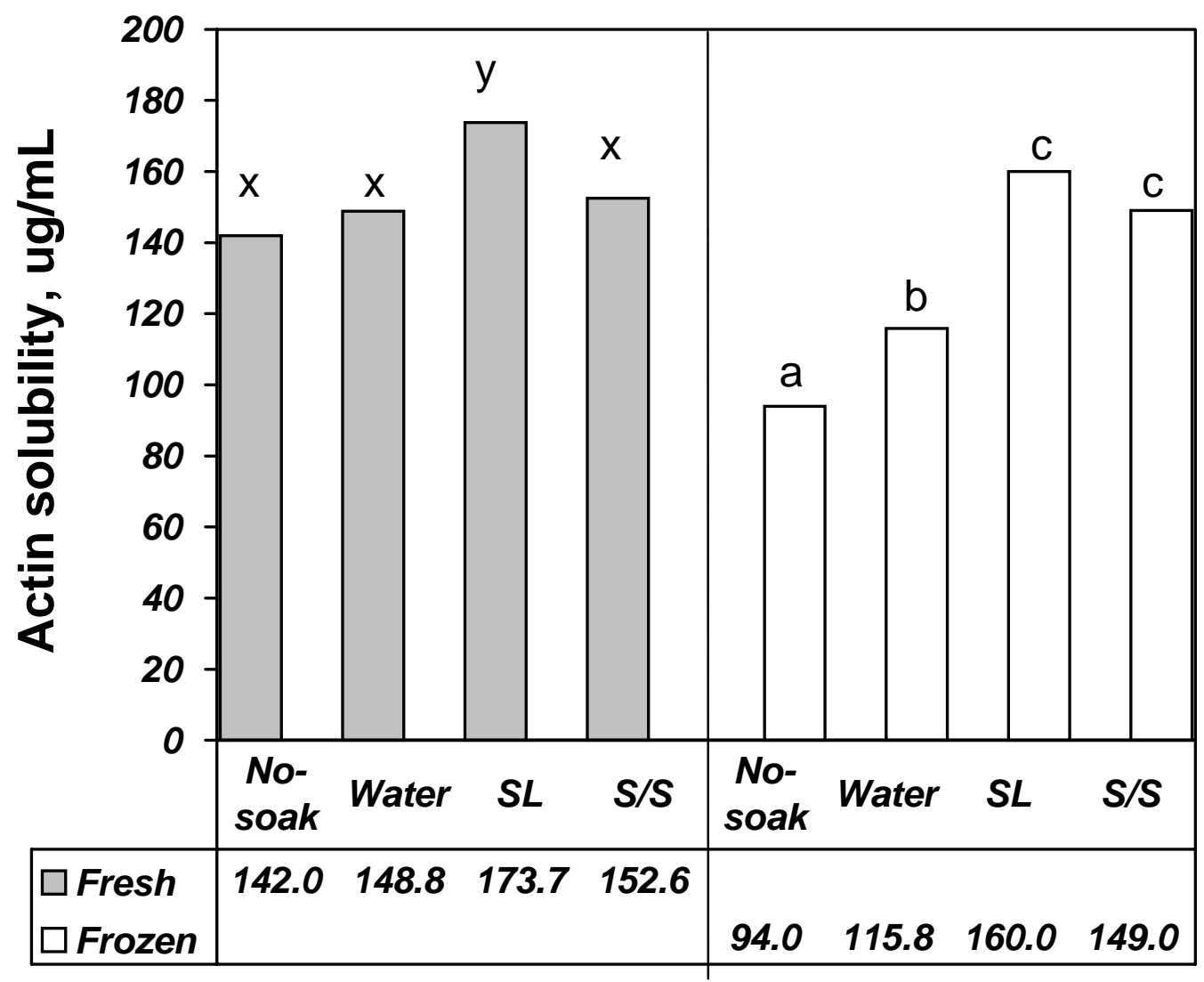

Figure 9. Effect of cryoprotectant on actin solubility.

No-soak= Fillets without soaking treatment

Water= Fillets soaked in water

$\mathrm{SL}=1 \%(\mathrm{w} / \mathrm{v})$ sodium lactate solution

$\mathrm{S} / \mathrm{S}=8 \%(\mathrm{w} / \mathrm{v})$ sucrose/sorbitol $(1: 1 \mathrm{w} / \mathrm{w})$ solution

${ }^{x y z}$ Means within fresh condition with different superscripts are different $(p<0.05)$.

${ }^{a b c}$ Means within frozen condition with different superscripts are different $(p<0.05)$. 


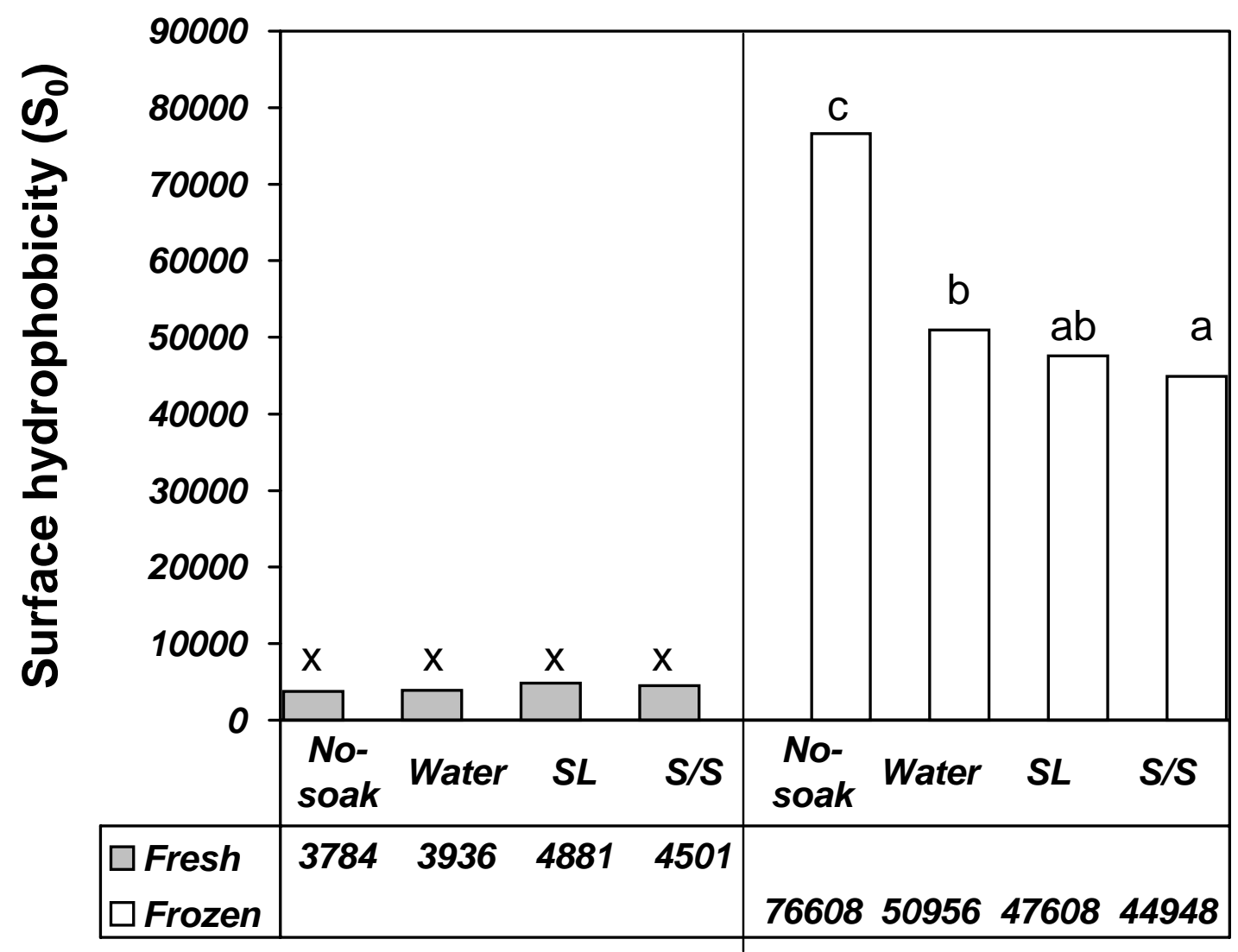

Figure 10. Effect of cryoprotectant on surface hydrophobicity.

No-soak= Fillets without soaking treatment

Water= Fillets soaked in water

$\mathrm{SL}=1 \%(\mathrm{w} / \mathrm{v})$ sodium lactate solution

$\mathrm{S} / \mathrm{S}=8 \%(\mathrm{w} / \mathrm{v})$ sucrose/sorbitol $(1: 1 \mathrm{w} / \mathrm{w})$ solution

${ }^{x y z}$ Means within fresh condition with different superscripts are different $(p<0.05)$.

${ }^{a b c}$ Means within frozen condition with different superscripts are different $(p<0.05)$. 


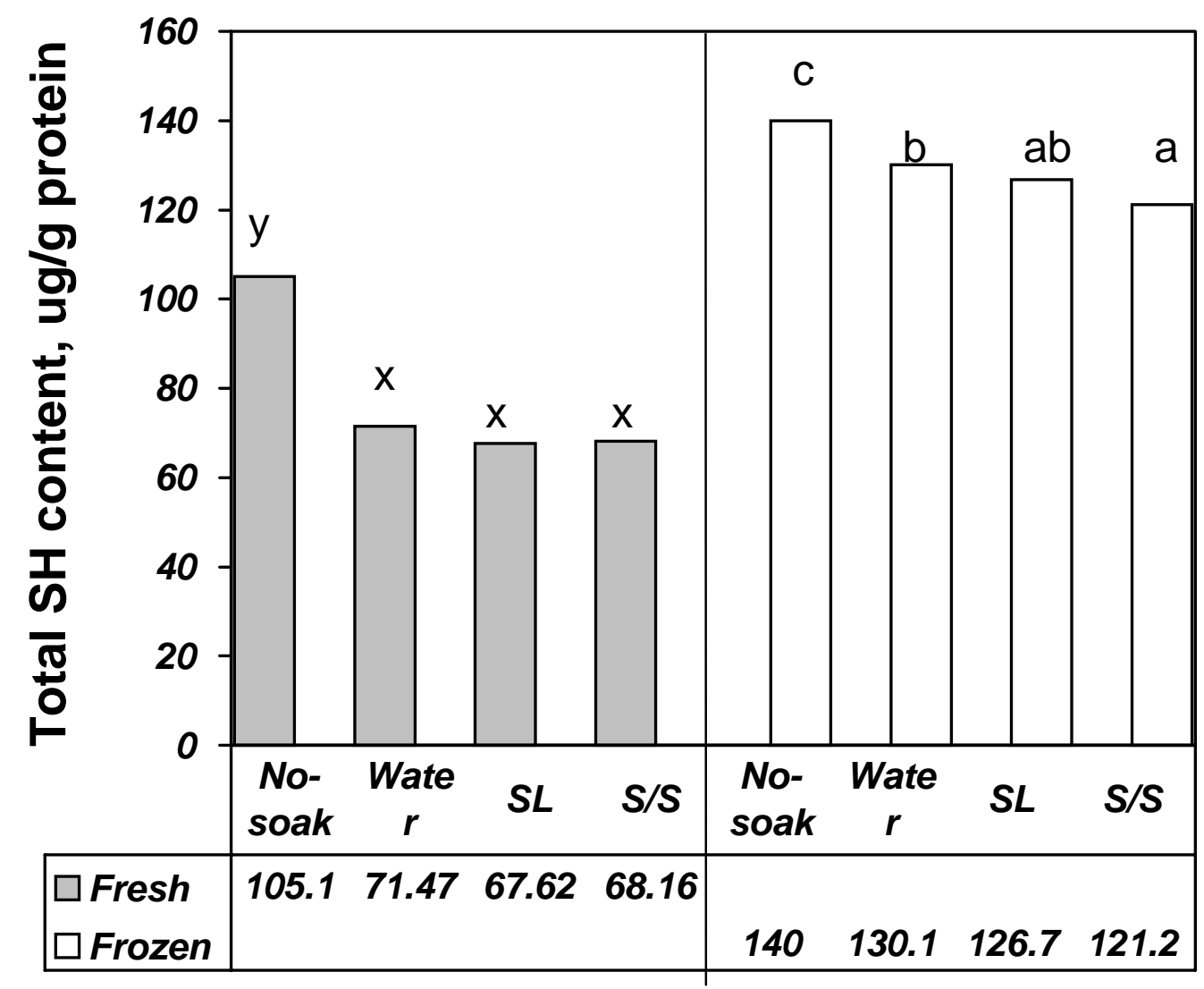

Figure 11. Effect of cryoprotectant on total sulfhydryl content.

No-soak= Fillets without soaking treatment

Water= Fillets soaked in water

$\mathrm{SL}=1 \%(\mathrm{w} / \mathrm{v})$ sodium lactate solution

$\mathrm{S} / \mathrm{S}=8 \%(\mathrm{w} / \mathrm{v})$ sucrose/sorbitol $(1: 1 \mathrm{w} / \mathrm{w})$ solution

${ }^{x y z}$ Means within fresh condition with different superscripts are different $(p<0.05)$.

${ }^{a b c}$ Means within frozen condition with different superscripts are different $(p<0.05)$. 


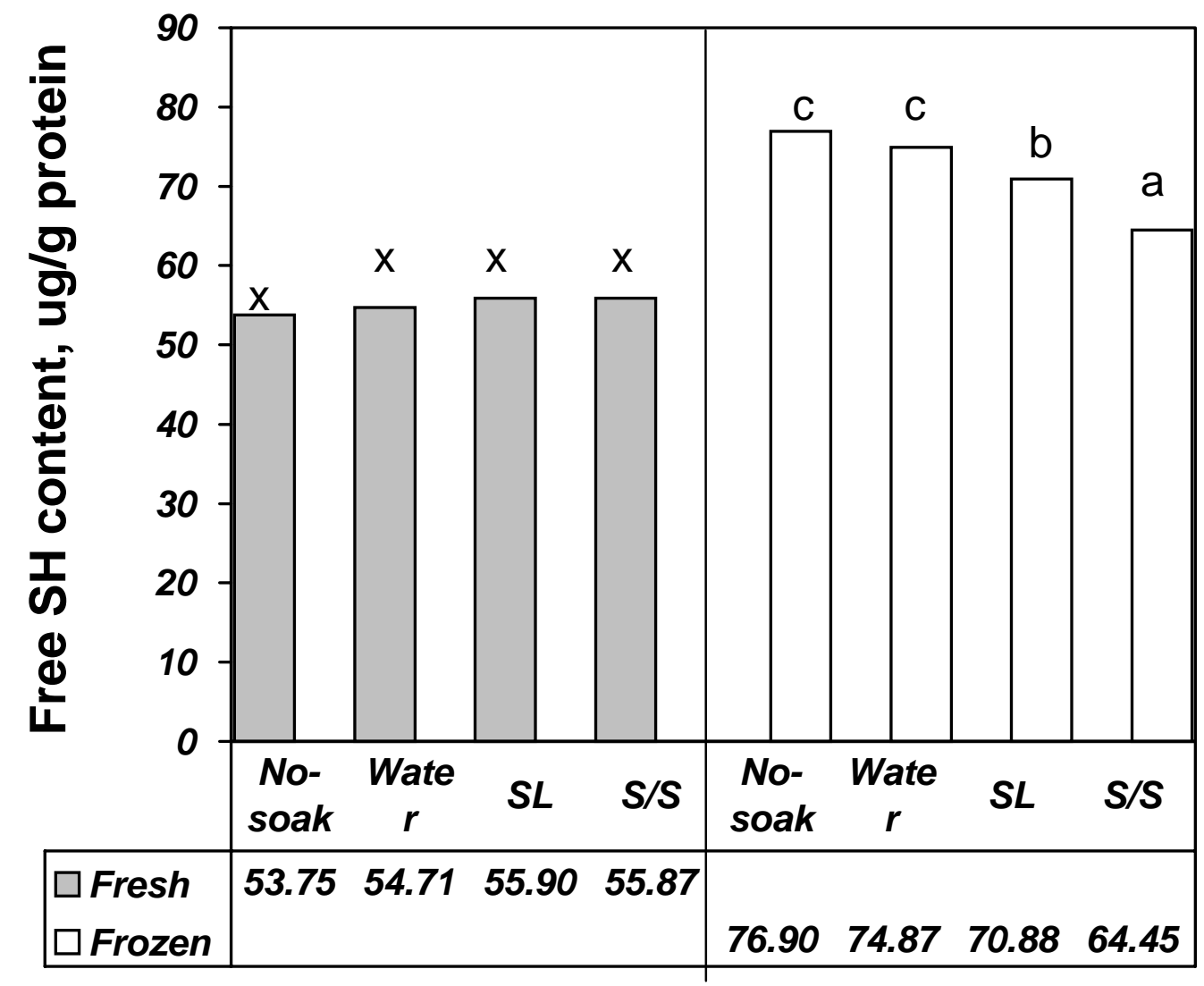

Figure 12. Effect of cryoprotectant on free sulfhydryl content.

No-soak= Fillets without soaking treatment

Water= Fillets soaked in water

$\mathrm{SL}=1 \%(\mathrm{w} / \mathrm{v})$ sodium lactate solution

$\mathrm{S} / \mathrm{S}=8 \%(\mathrm{w} / \mathrm{v})$ sucrose/sorbitol $(1: 1 \mathrm{w} / \mathrm{w})$ solution

${ }^{x y z}$ Means within fresh condition with different superscripts are different $(p<0.05)$.

${ }^{a b c}$ Means within frozen condition with different superscripts are different $(p<0.05)$. 
Figure 13. Effect of cryoprotectant with or without $0.05 \%(w / v)$ magnesium chloride $\left(\mathrm{MgCl}_{2}\right)$ on disulfide sulfhydryl content.

Cont= Fillets without soaking treatment

Water $=$ Fillets soaked in water

$S L=1 \%(w / v)$ sodium lactate solution

$\mathrm{S} / \mathrm{S}=8 \%(\mathrm{w} / \mathrm{v})$ sucrose/sorbitol $(1: 1 \mathrm{w} / \mathrm{w})$ solution

${ }^{x y z}$ Means within fresh condition with different superscripts are different $(p<0.05)$.

${ }^{a b c}$ Means within frozen condition with different superscripts are different $(p<0.05)$. 


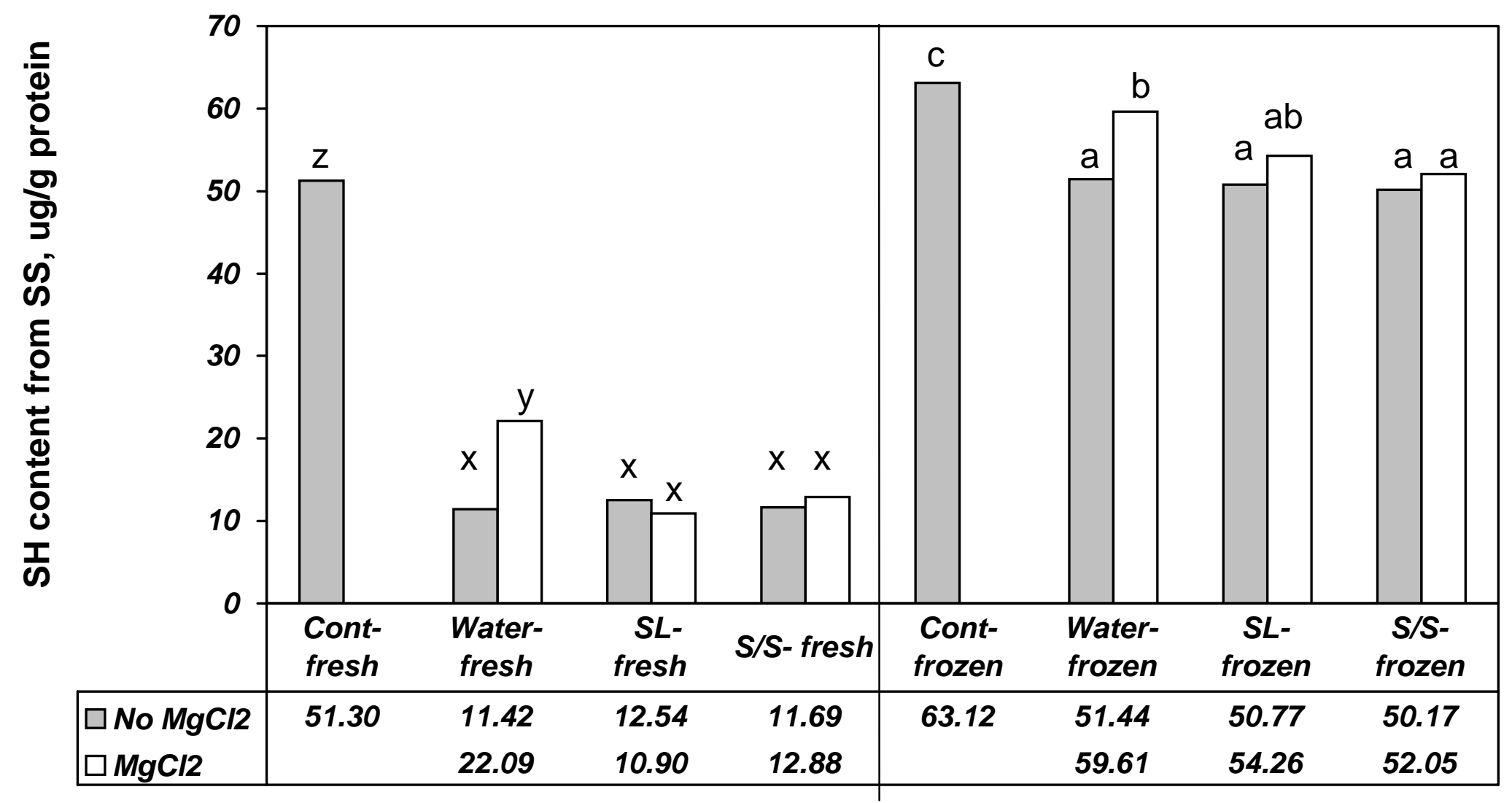




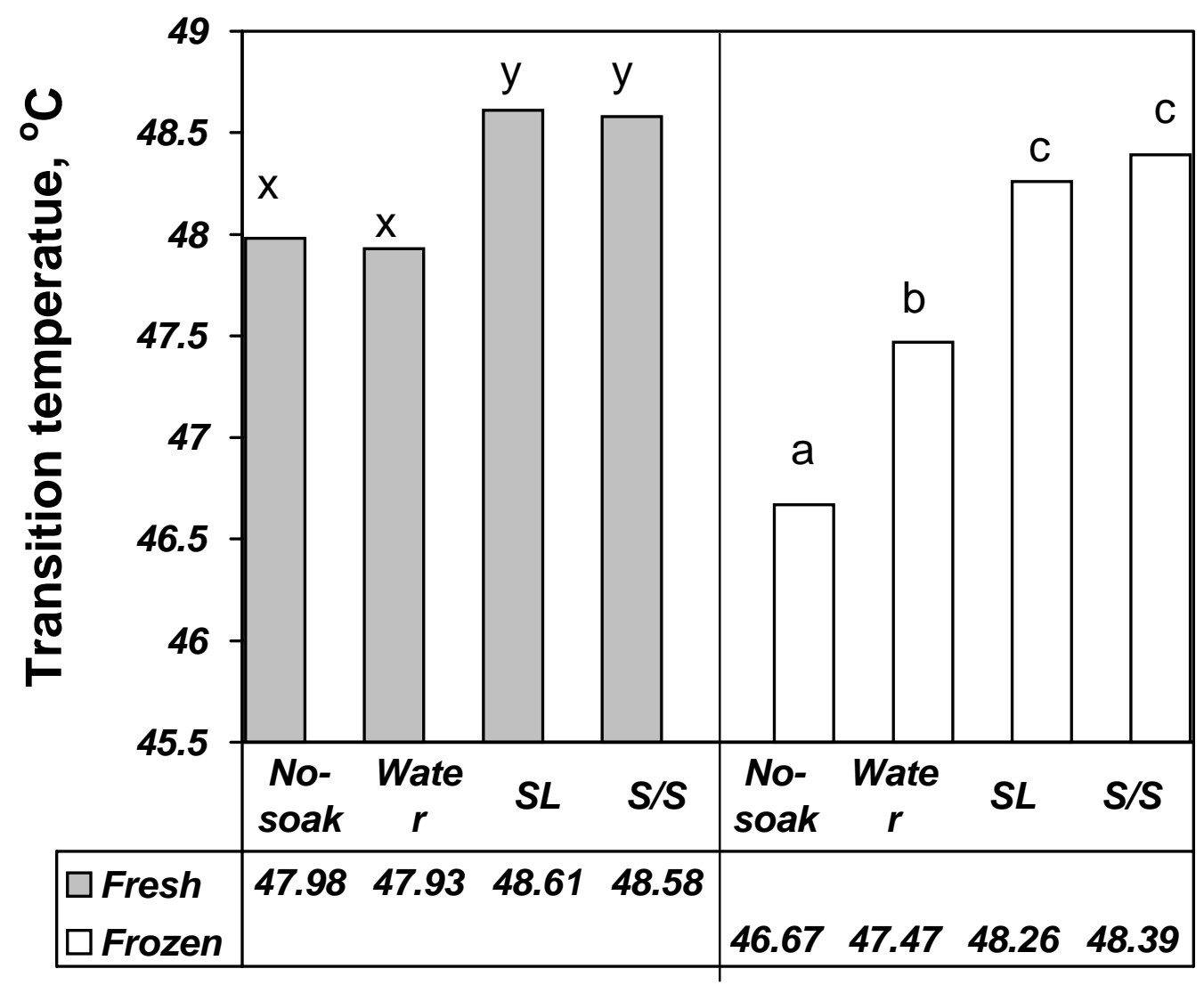

Figure 14. Effect of cryoprotectant on transition temperature of myosin.

No-soak= Fillets without soaking treatment

Water= Fillets soaked in water

$\mathrm{SL}=1 \%(\mathrm{w} / \mathrm{v})$ sodium lactate solution

$\mathrm{S} / \mathrm{S}=8 \%(\mathrm{w} / \mathrm{v})$ sucrose/sorbitol $(1: 1 \mathrm{w} / \mathrm{w})$ solution

${ }^{x y z}$ Means within fresh condition with different superscripts are different $(p<0.05)$.

${ }^{a b c}$ Means within frozen condition with different superscripts are different $(p<0.05)$. 


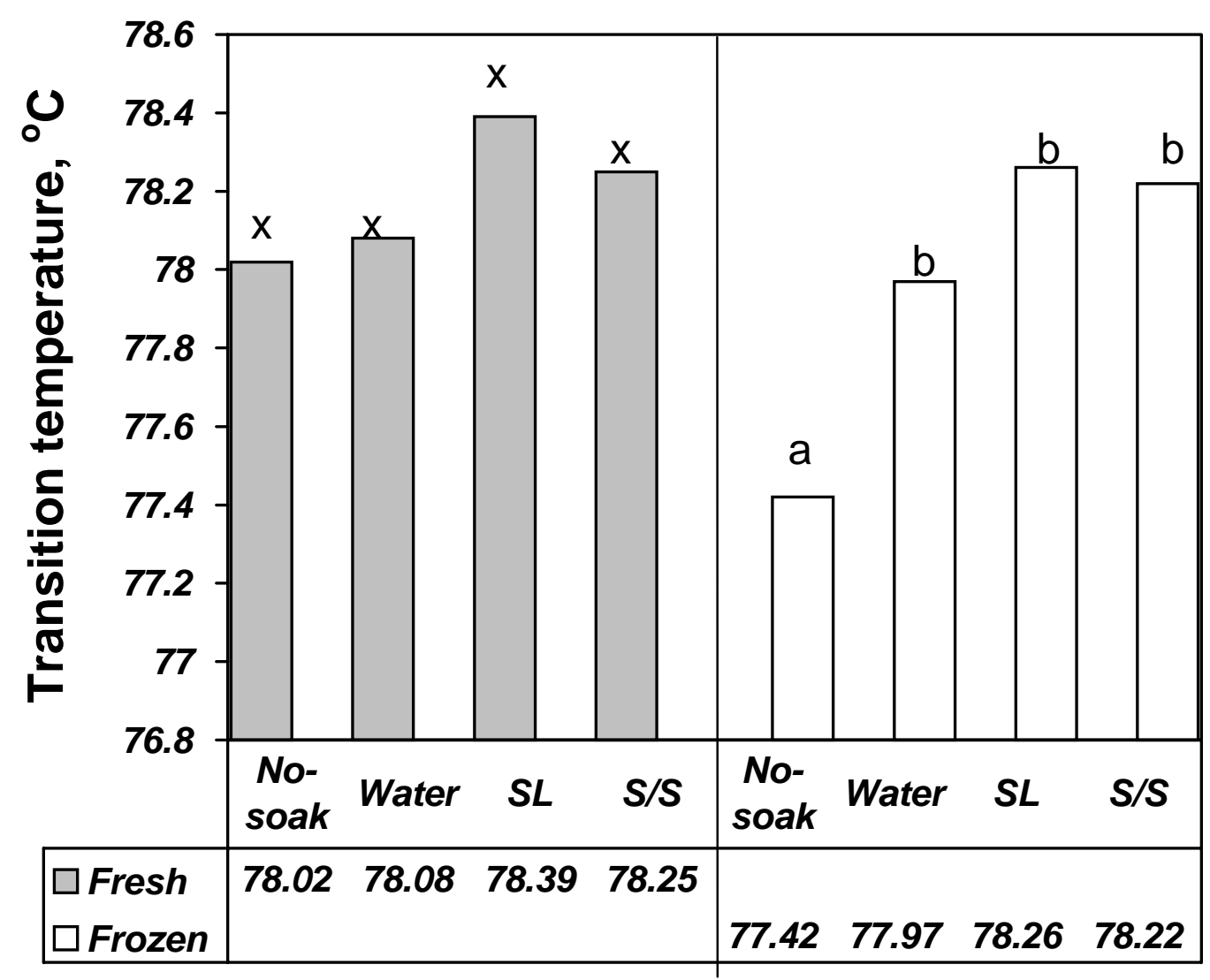

Figure 15. Effect of cryoprotectant on transition temperature of actin.

No-soak= Fillets without soaking treatment

Water= Fillets soaked in water

$S L=1 \%(w / v)$ sodium lactate solution

$\mathrm{S} / \mathrm{S}=8 \%(\mathrm{w} / \mathrm{v})$ sucrose/sorbitol $(1: 1 \mathrm{w} / \mathrm{w})$ solution

${ }^{x y z}$ Means within fresh condition with different superscripts are different $(p<0.05)$.

${ }^{a b c}$ Means within frozen condition with different superscripts are different $(p<0.05)$. 


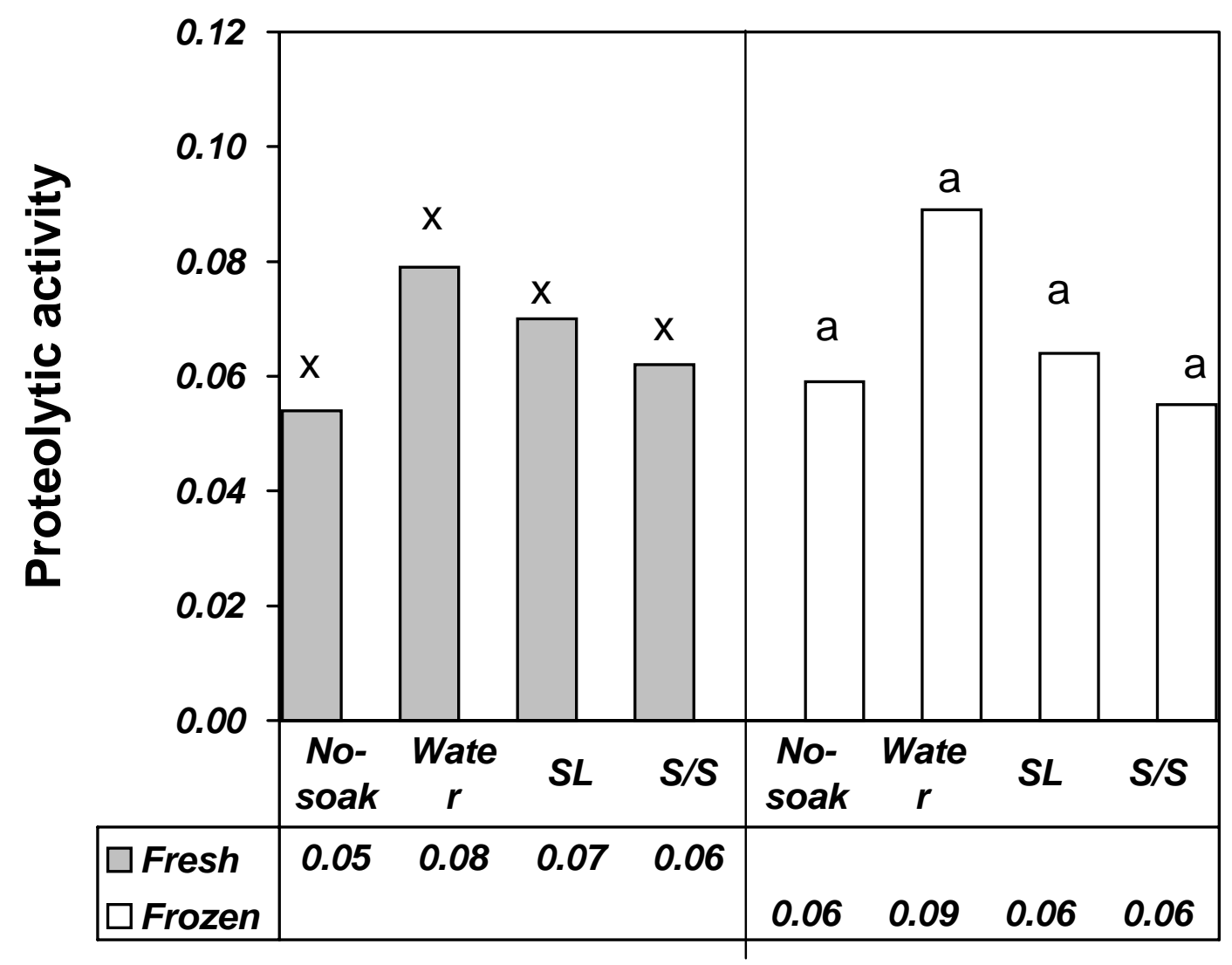

Figure 16. Effect of cryoprotectant on muscle endogenous protease activity. No-soak= Fillets without soaking treatment

Water= Fillets soaked in water

$\mathrm{SL}=1 \%(\mathrm{w} / \mathrm{v})$ sodium lactate solution

$\mathrm{S} / \mathrm{S}=8 \%(\mathrm{w} / \mathrm{v})$ sucrose/sorbitol $(1: 1 \mathrm{w} / \mathrm{w})$ solution

${ }^{x y z}$ Means within fresh condition with different superscripts are different $(p<0.05)$.

${ }^{a b c}$ Means within frozen condition with different superscripts are different $(p<0.05)$. 


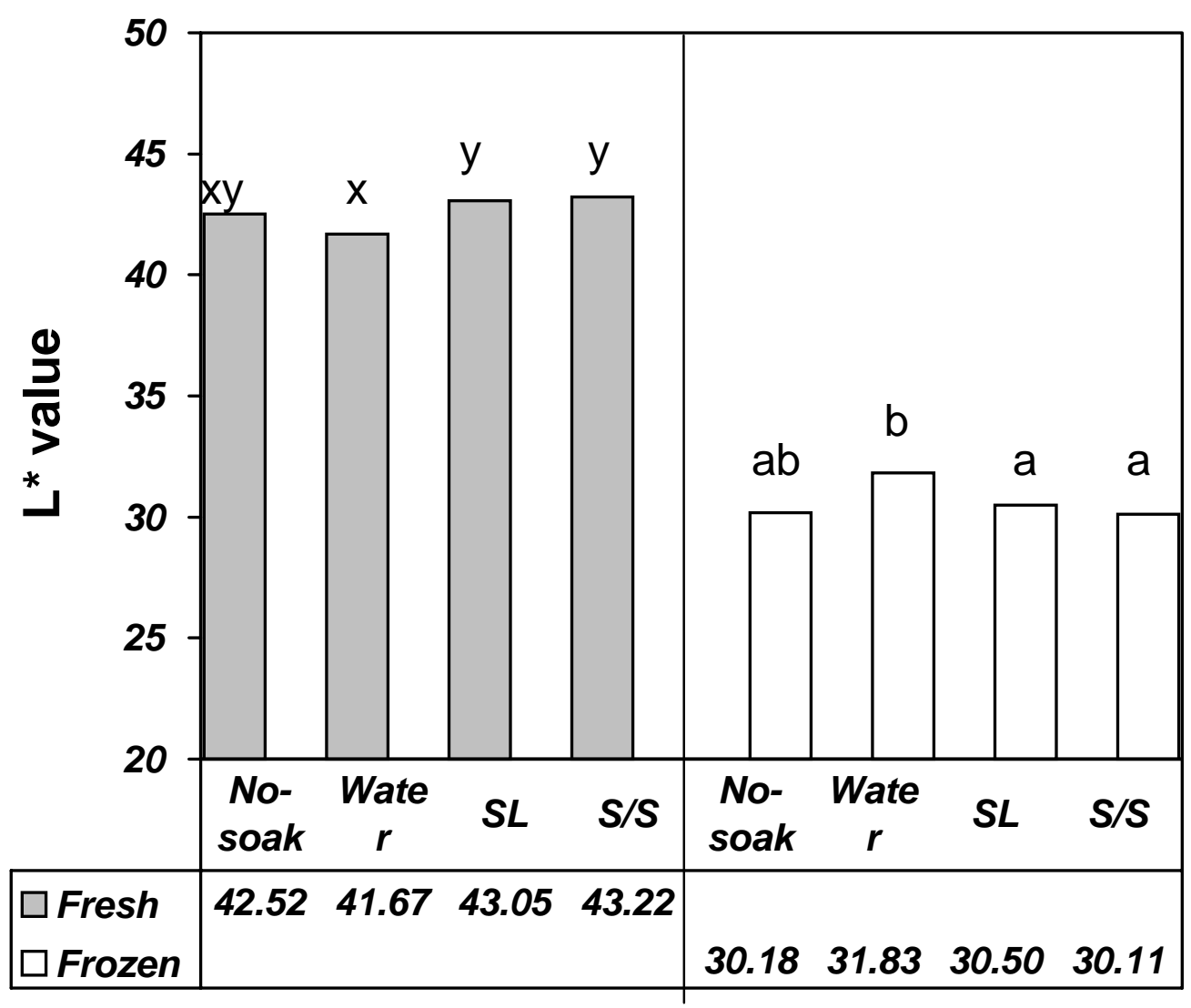

Figure 17. Effect of cryoprotectant on $L^{*}$ value.

No-soak= Fillets without soaking treatment

Water= Fillets soaked in water

$S L=1 \%(w / v)$ sodium lactate solution

$\mathrm{S} / \mathrm{S}=8 \%(\mathrm{w} / \mathrm{v})$ sucrose/sorbitol $(1: 1 \mathrm{w} / \mathrm{w})$ solution

${ }^{x y z}$ Means within fresh condition with different superscripts are different $(p<0.05)$.

${ }^{a b c}$ Means within frozen condition with different superscripts are different $(p<0.05)$. 


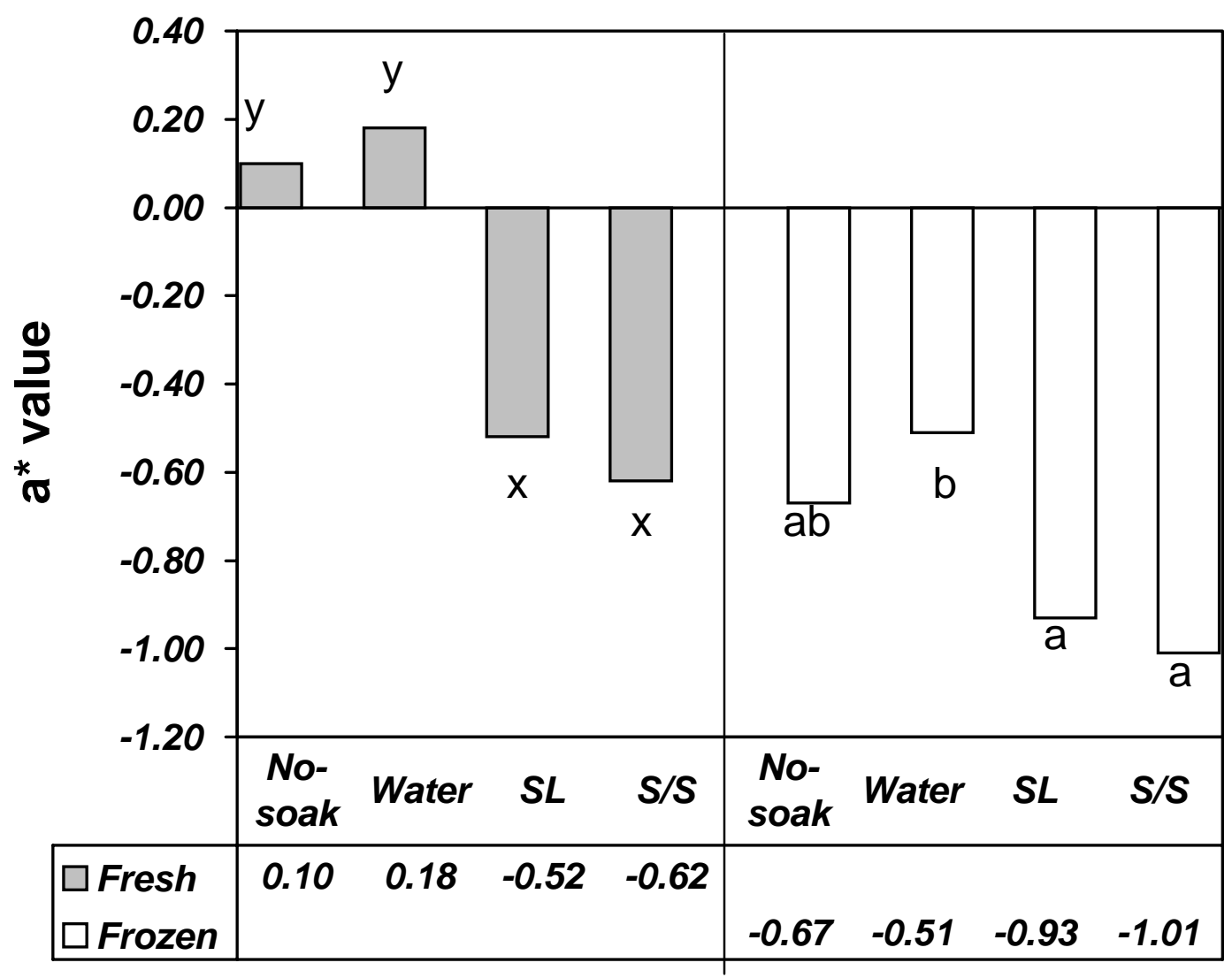

Figure 18. Effect of cryoprotectant on $a^{*}$ value.

No -soak= Fillets without soaking treatment

Water= Fillets soaked in water

$S L=1 \%(w / v)$ sodium lactate solution

$\mathrm{S} / \mathrm{S}=8 \%(\mathrm{w} / \mathrm{v})$ sucrose/sorbitol $(1: 1 \mathrm{w} / \mathrm{w})$ solution

${ }^{x y z}$ Means within fresh condition with different superscripts are different $(p<0.05)$.

${ }^{a b c}$ Means within frozen condition with different superscripts are different $(p<0.05)$. 


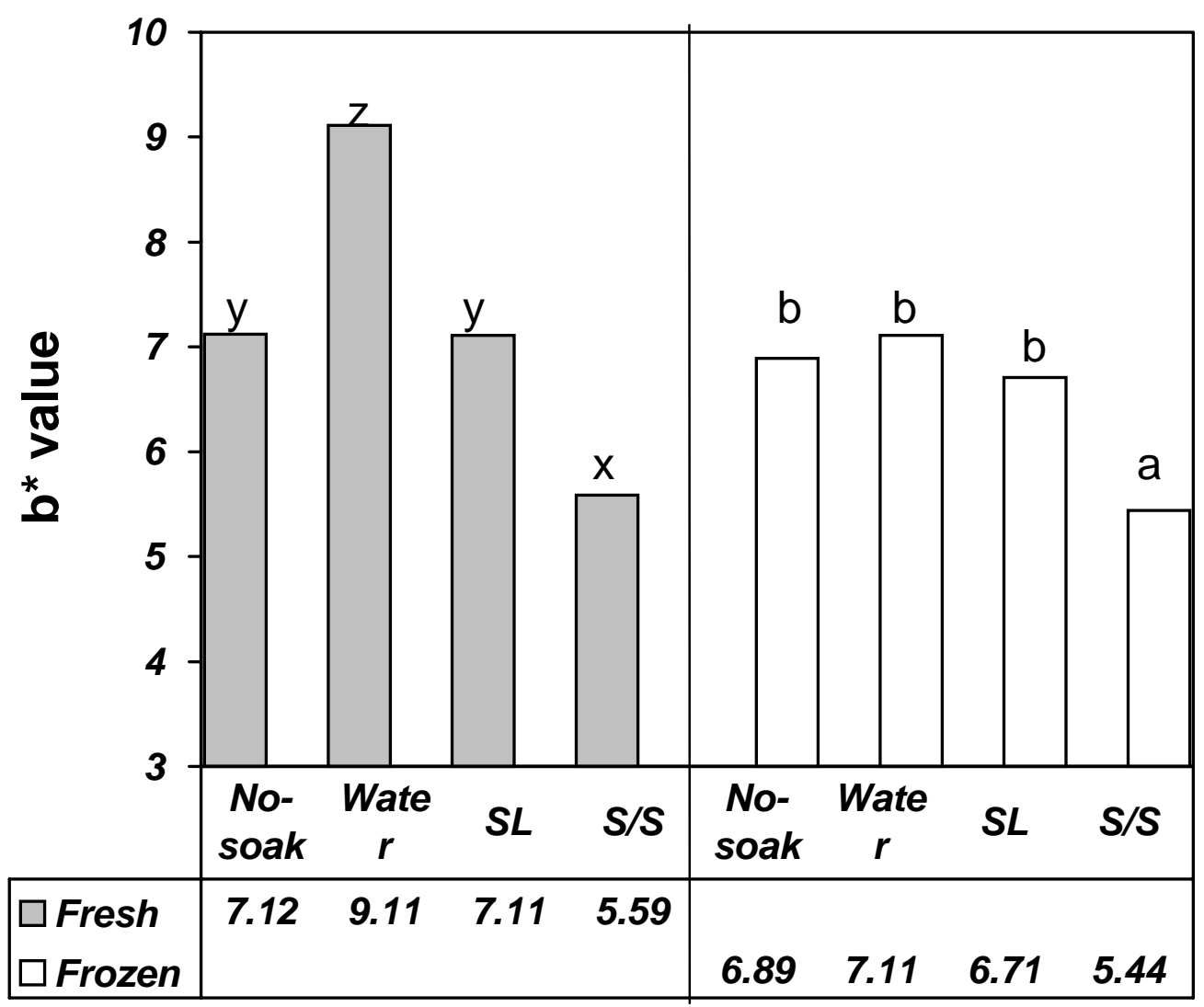

Figure 19. Effect of cryoprotectant on $b^{*}$ value.

No-soak= Fillets without soaking treatment

Water= Fillets soaked in water

$S L=1 \%(w / v)$ sodium lactate solution

$\mathrm{S} / \mathrm{S}=8 \%(\mathrm{w} / \mathrm{v})$ sucrose/sorbitol $(1: 1 \mathrm{w} / \mathrm{w})$ solution

${ }^{x y z}$ Means within fresh condition with different superscripts are different $(p<0.05)$.

${ }^{a b c}$ Means within frozen condition with different superscripts are different $(p<0.05)$. 


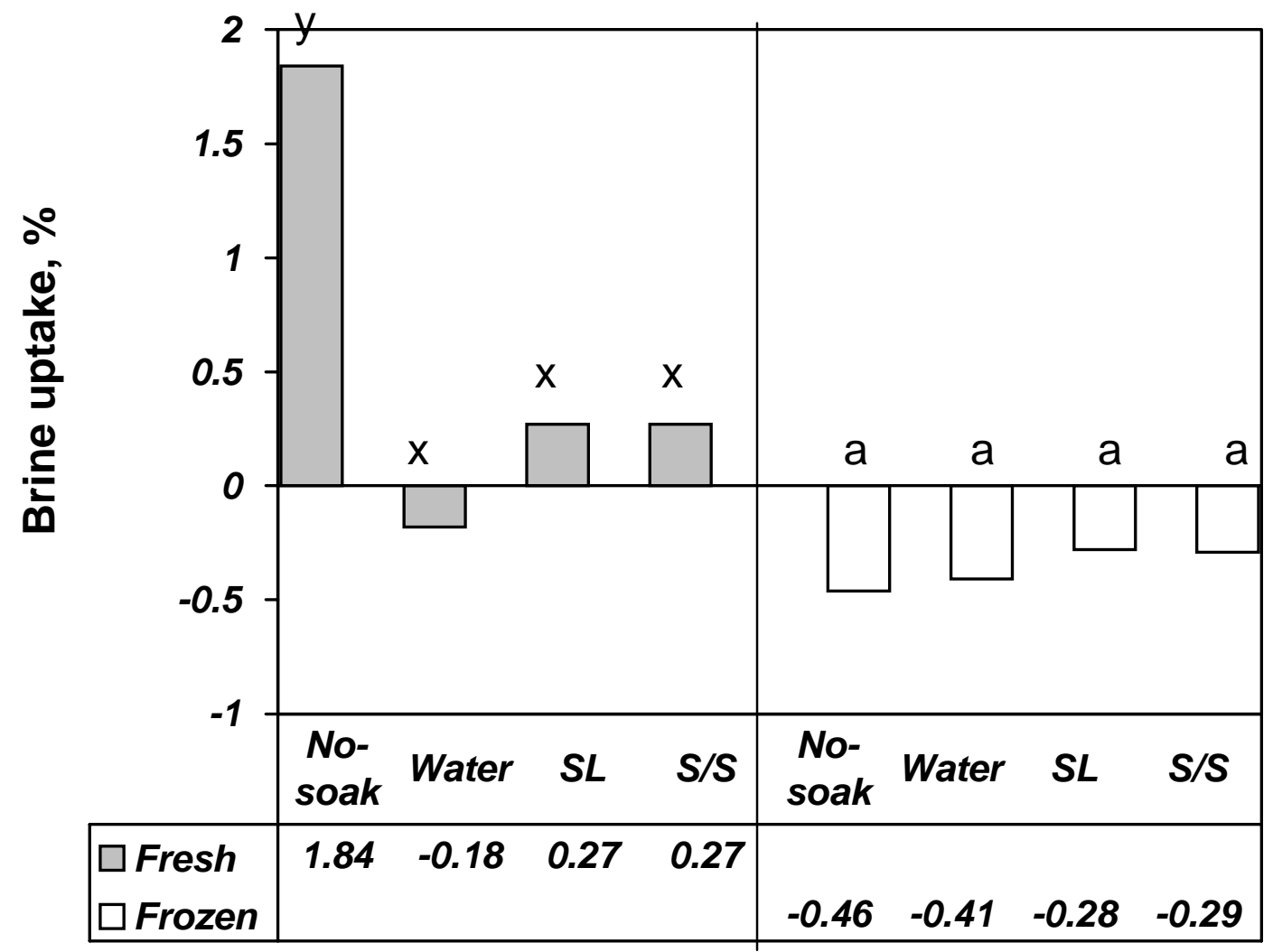

Figure 20. Effect of cryoprotectant on brine uptake.

No-soak= Fillets without soaking treatment

Water $=$ Fillets soaked in water

$S L=1 \%(w / v)$ sodium lactate solution

$\mathrm{S} / \mathrm{S}=8 \%(\mathrm{w} / \mathrm{v})$ sucrose/sorbitol $(1: 1 \mathrm{w} / \mathrm{w})$ solution

${ }^{x y z}$ Means within fresh condition with different superscripts are different $(p<0.05)$.

${ }^{a b c}$ Means within frozen condition with different superscripts are different $(p<0.05)$. 


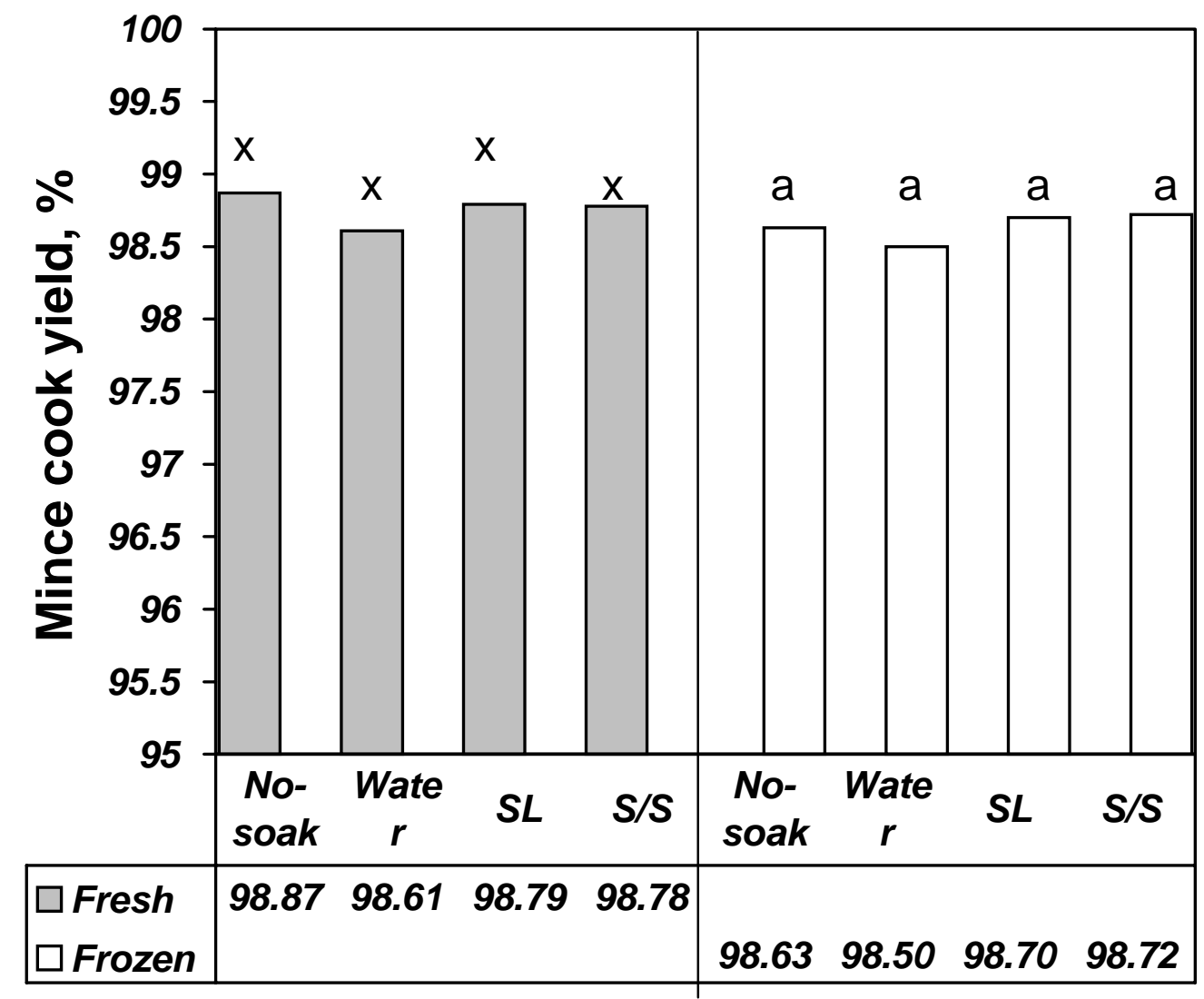

Figure 21. Effect of cryoprotectant on mince cook yield.

No-soak= Fillets without soaking treatment

Water= Fillets soaked in water

$\mathrm{SL}=1 \%(\mathrm{w} / \mathrm{v})$ sodium lactate solution

$\mathrm{S} / \mathrm{S}=8 \%(\mathrm{w} / \mathrm{v})$ sucrose/sorbitol $(1: 1 \mathrm{w} / \mathrm{w})$ solution

${ }^{x y z}$ Means within fresh condition with different superscripts are different $(p<0.05)$.

${ }^{a b c}$ Means within frozen condition with different superscripts are different $(p<0.05)$. 


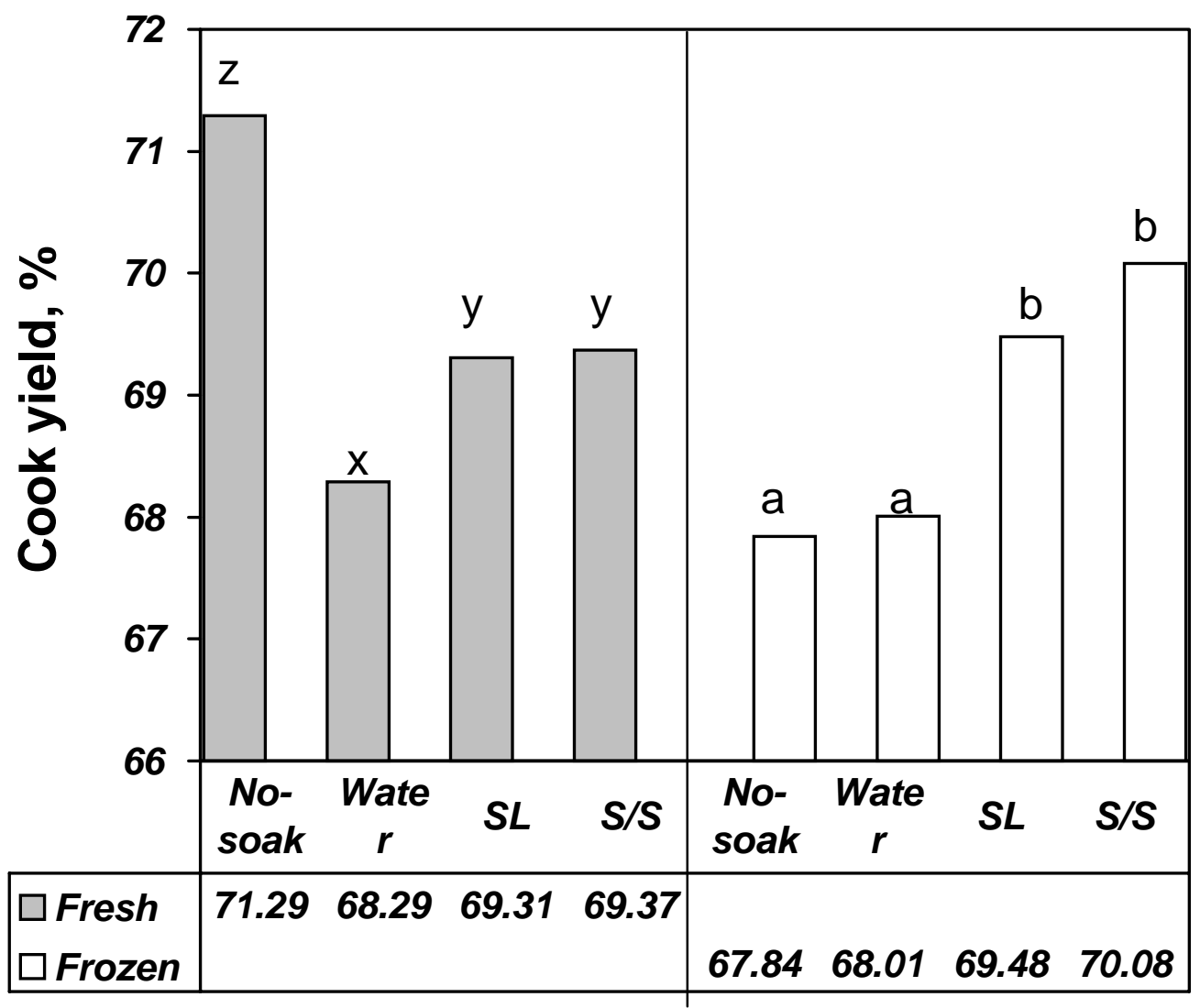

Figure 22. Effect of cryoprotectant on fillet cook yield.

No-soak= Fillets without soaking treatment

Water= Fillets soaked in water

$S L=1 \%(w / v)$ sodium lactate solution

$\mathrm{S} / \mathrm{S}=8 \%(\mathrm{w} / \mathrm{v})$ sucrose/sorbitol $(1: 1 \mathrm{w} / \mathrm{w})$ solution

${ }^{x y z}$ Means within fresh condition with different superscripts are different $(p<0.05)$.

${ }^{a b c}$ Means within frozen condition with different superscripts are different $(p<0.05)$. 


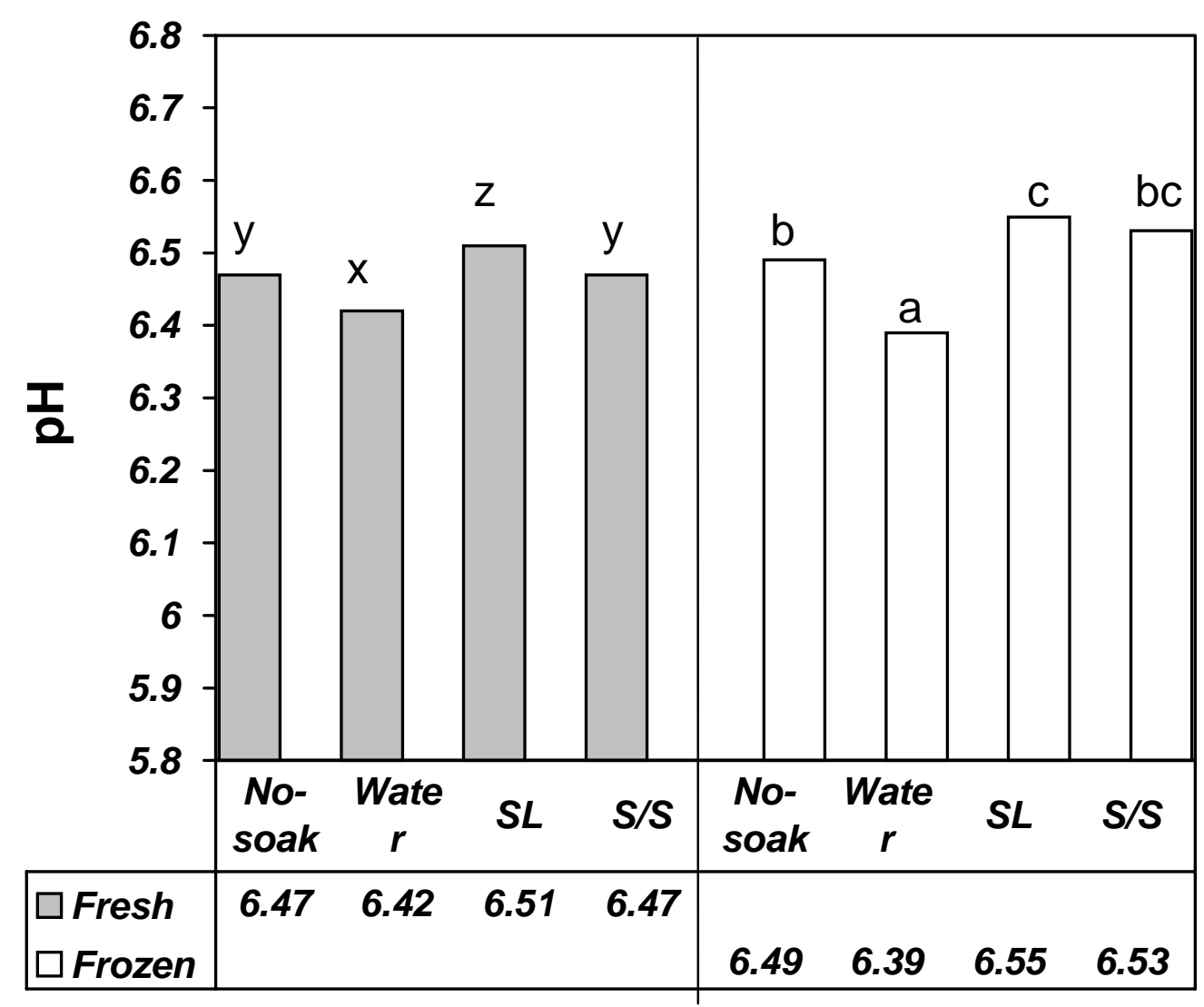

Figure 23. Effect of cryoprotectant on cooked pH.

No-soak= Fillets without soaking treatment

Water= Fillets soaked in water

$\mathrm{SL}=1 \%(\mathrm{w} / \mathrm{v})$ sodium lactate solution

$\mathrm{S} / \mathrm{S}=8 \%(\mathrm{w} / \mathrm{v})$ sucrose/sorbitol $(1: 1 \mathrm{w} / \mathrm{w})$ solution

${ }^{x y z}$ Means within fresh condition with different superscripts are different $(p<0.05)$.

${ }^{a b c}$ Means within frozen condition with different superscripts are different $(p<0.05)$. 


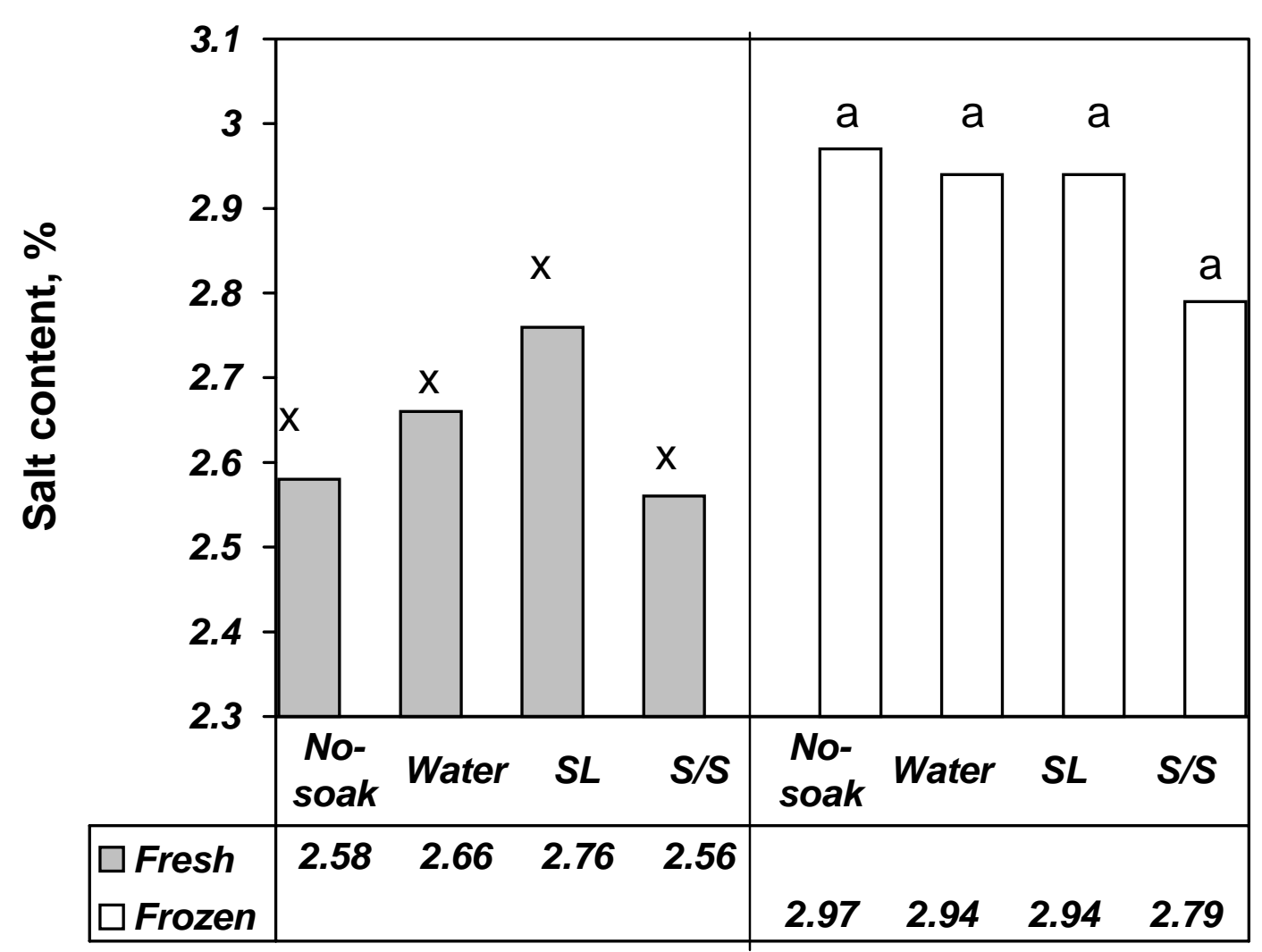

Figure 24. Effect of cryoprotectant on salt content of smoked fillets.

No-soak= Fillets without soaking treatment

Water $=$ Fillets soaked in water

$\mathrm{SL}=1 \%(\mathrm{w} / \mathrm{v})$ sodium lactate solution

$\mathrm{S} / \mathrm{S}=8 \%(\mathrm{w} / \mathrm{v})$ sucrose/sorbitol $(1: 1 \mathrm{w} / \mathrm{w})$ solution

${ }^{x y z}$ Means within fresh condition with different superscripts are different $(p<0.05)$.

${ }^{a b c}$ Means within frozen condition with different superscripts are different $(p<0.05)$. 


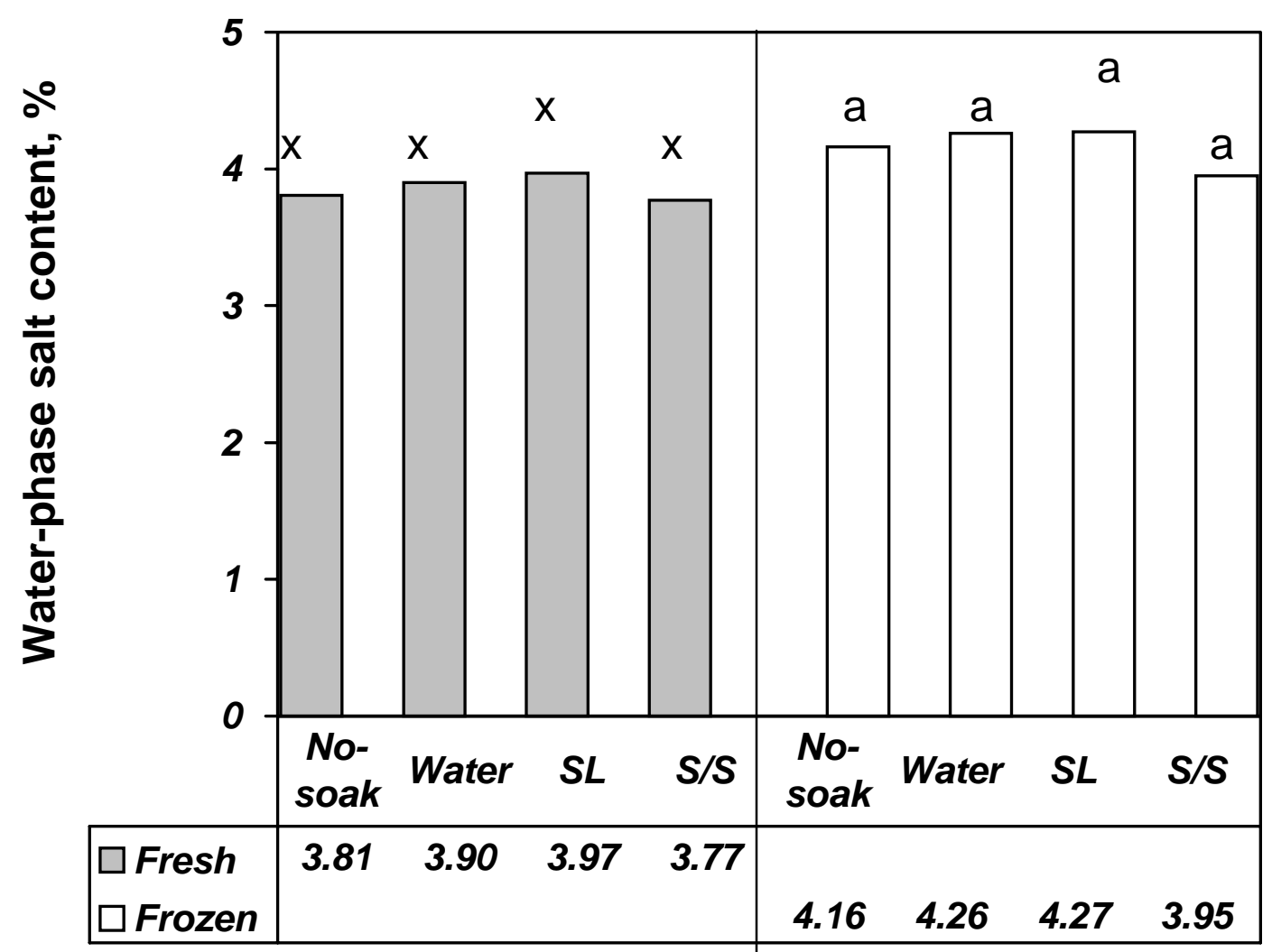

Figure 25. Effect of cryoprotectant on water-phase salt content of smoked fillets. No-soak= Fillets without soaking treatment Water $=$ Fillets soaked in water

$\mathrm{SL}=1 \%(\mathrm{w} / \mathrm{v})$ sodium lactate solution $\mathrm{S} / \mathrm{S}=8 \%(\mathrm{w} / \mathrm{v})$ sucrose/sorbitol $(1: 1 \mathrm{w} / \mathrm{w})$ solution ${ }^{x y z}$ Means within fresh condition with different superscripts are different $(p<0.05)$. ${ }^{a b c}$ Means within frozen condition with different superscripts are different $(p<0.05)$. 


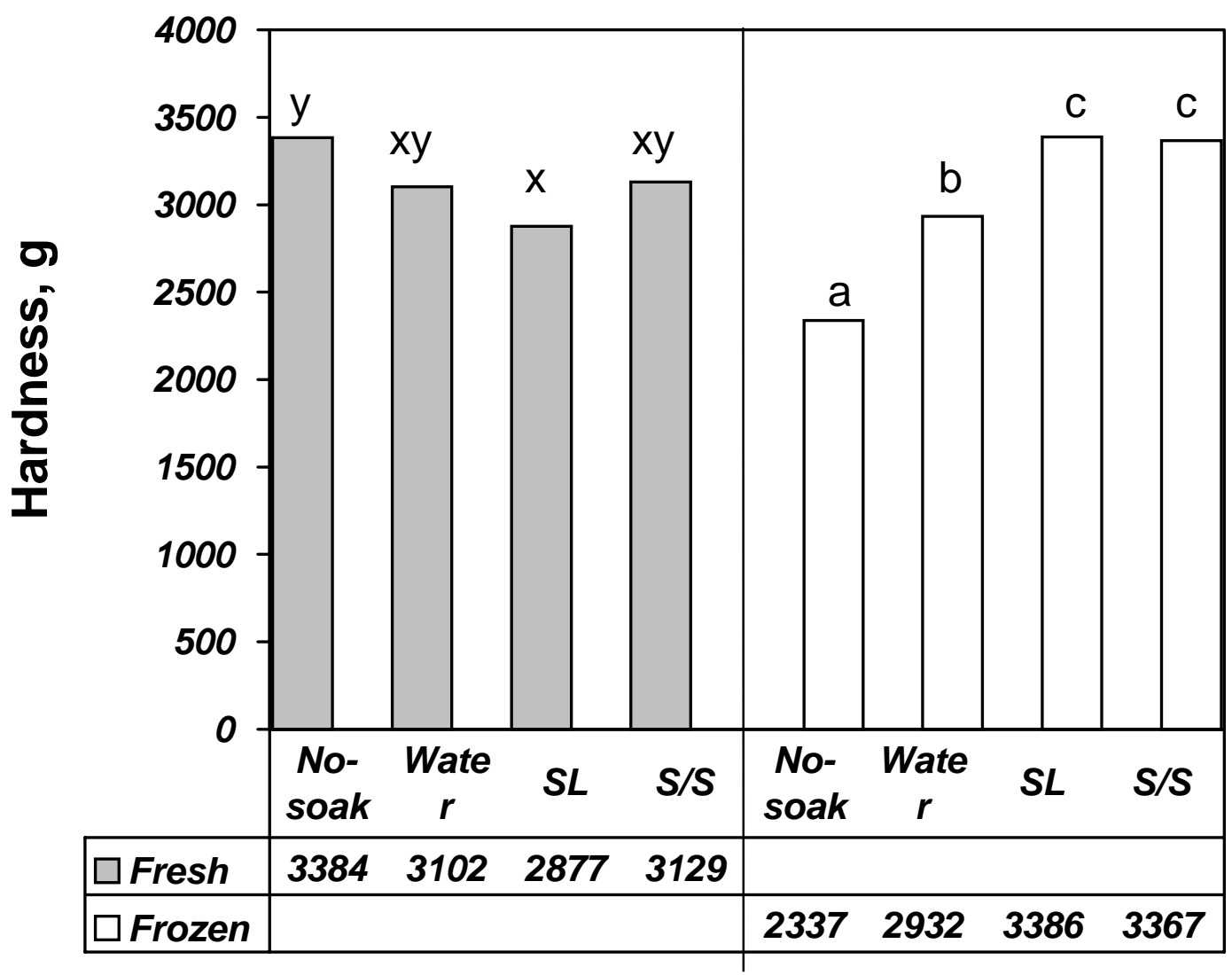

Figure 26. Effect of cryoprotectant on hardness of cooked mince.

No-soak= Fillets without soaking treatment

Water= Fillets soaked in water

$\mathrm{SL}=1 \%(\mathrm{w} / \mathrm{v})$ sodium lactate solution

$S / S=8 \%(w / v)$ sucrose/sorbitol $(1: 1 \mathrm{w} / \mathrm{w})$ solution

${ }^{x y z}$ Means within fresh condition with different superscripts are different $(p<0.05)$.

${ }^{a b c}$ Means within frozen condition with different superscripts are different $(p<0.05)$. 


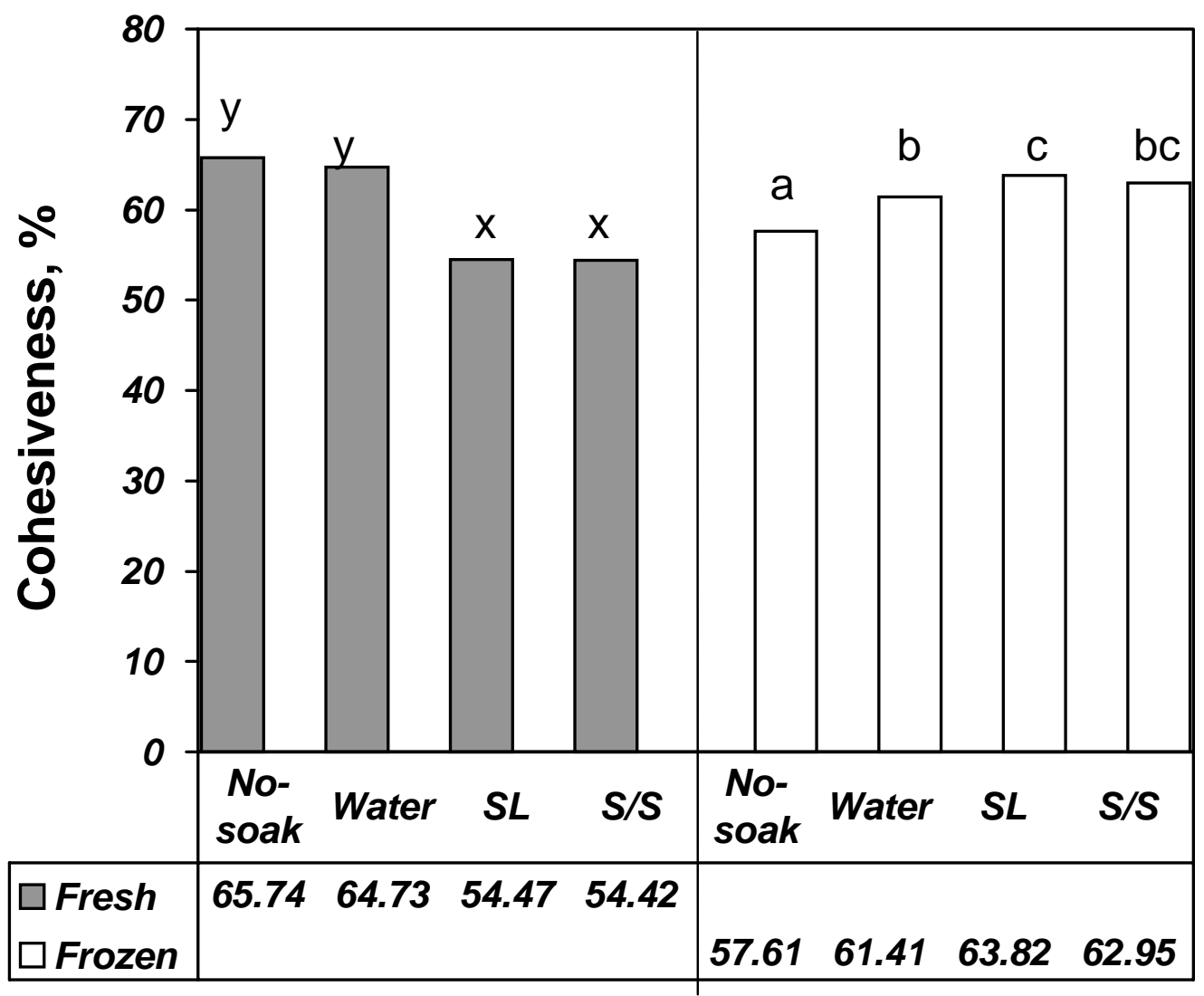

Figure 27. Effect of cryoprotectant on cohesiveness of cooked mince.

No-soak= Fillets without soaking treatment

Water= Fillets soaked in water

$\mathrm{SL}=1 \%(\mathrm{w} / \mathrm{v})$ sodium lactate solution

$\mathrm{S} / \mathrm{S}=8 \%(\mathrm{w} / \mathrm{v})$ sucrose/sorbitol $(1: 1 \mathrm{w} / \mathrm{w})$ solution

${ }^{x y z}$ Means within fresh condition with different superscripts are different $(p<0.05)$.

${ }^{a b c}$ Means within frozen condition with different superscripts are different $(p<0.05)$. 


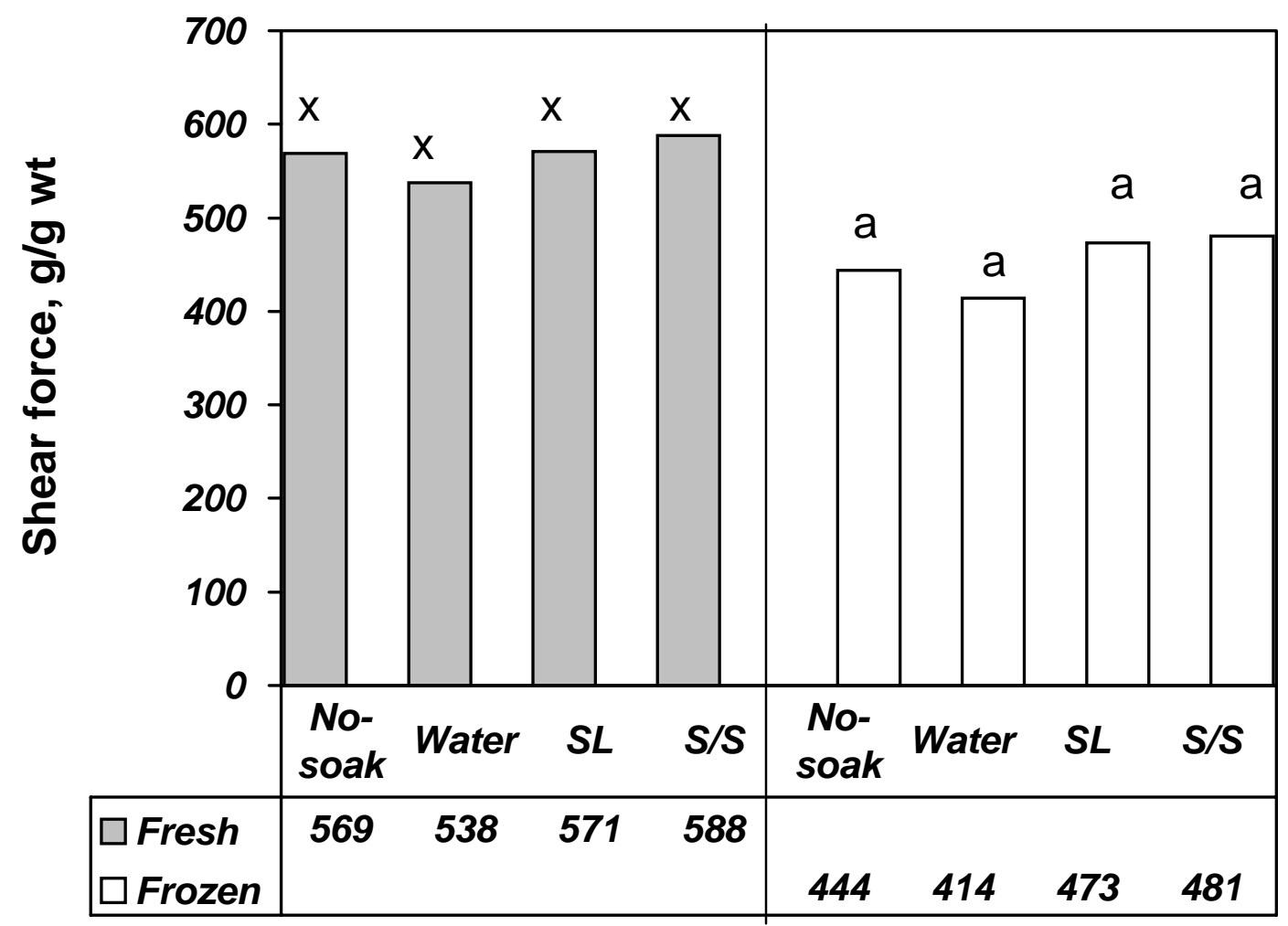

Figure 28. Effect of cryoprotectant on fillet shear force.

No-soak= Fillets without soaking treatment

Water $=$ Fillets soaked in water

$S L=1 \%(w / v)$ sodium lactate solution

$\mathrm{S} / \mathrm{S}=8 \%(\mathrm{w} / \mathrm{v})$ sucrose/sorbitol $(1: 1 \mathrm{w} / \mathrm{w})$ solution

${ }^{x y z}$ Means within fresh condition with different superscripts are different $(p<0.05)$.

${ }^{a b c}$ Means within frozen condition with different superscripts are different $(p<0.05)$. 
Table 1. Effect of frozen storage on physicochemical and quality attributes of intact fillets and smoked products from the no-soak control $(\alpha=0.05)$.

\begin{tabular}{lll}
\hline Decreased & Increased & No effect (trend) \\
\hline Total protein solubility & Hydrophobicity & Muscle pH (decreased) \\
Myofibrillar protein solubility & Total, and free sulfhydryls & Transition temperature of actin (decreased) \\
Transition temp of myosin & Sulfhydryls from disulfides & Total myosin (increased) \\
Muscle L $^{*}$ and $\mathrm{a}^{*}$ values & Total and water-phase salt & Endogenous protease activity (increased) \\
Brine uptake & Brined and cooked ash & Muscle b* value (increased) \\
Hardness and cohesiveness & & Mince and fillet cook yield (decreased) \\
Fillet shear force & & Cooked pH (increased) \\
& & Brined moisture, fat, and protein (increased) \\
& & Cooked moisture and fat (decreased) \\
& & Cooked protein (increased) \\
\hline
\end{tabular}


Table 2. Effect of $0.5 \%(\mathrm{w} / \mathrm{v})$ phosphate on muscle $\mathrm{pH}$, total protein and myofibrillar protein solubility, and total myosin from fresh and frozen groups.

\begin{tabular}{|c|c|c|c|c|c|c|}
\hline \multirow[b]{2}{*}{ Trait } & \multicolumn{3}{|c|}{ Fresh } & \multicolumn{3}{|c|}{ Frozen } \\
\hline & No-soak* & No phosphate & Phosphate & No-soak & No phosphate & Phosphate \\
\hline Muscle pH & $6.43^{x}$ & $6.43^{x}$ & $6.49^{y}$ & $6.42^{a}$ & $6.41^{a}$ & $6.47^{b}$ \\
\hline Total protein solubility, $\mathrm{mg} / \mathrm{mL}$ & $5.22^{x}$ & $5.69^{x y}$ & $6.11^{y}$ & $4.36^{a}$ & $4.84^{b}$ & $5.21^{b}$ \\
\hline Myosin solubility, $\mu \mathrm{g} / \mathrm{mL}$ & $203^{y}$ & $184^{x}$ & $215^{y}$ & $105^{a}$ & $150^{b}$ & $186^{c}$ \\
\hline Total myosin, mg/g muscle & $58.80^{x}$ & $57.69^{x}$ & $57.20^{x}$ & $55.20^{a}$ & $55.42^{a}$ & $55.57^{a}$ \\
\hline Actin solubility, $\mu \mathrm{g} / \mathrm{mL}$ & $142^{x}$ & $153^{y}$ & $164^{z}$ & $94^{\mathrm{a}}$ & $122^{b}$ & $155^{c}$ \\
\hline
\end{tabular}

${ }^{*}$ No-soak = Fillets without soaking treatment

${ }^{x y z}$ Means within fresh condition with different superscripts are different $(p<0.05)$.

${ }^{a b c}$ Means within frozen condition with different superscripts are different $(p<0.05)$. 
Table 3. Effect of $0.5 \%(\mathrm{w} / \mathrm{v})$ magnesium chloride $\left(\mathrm{MgCl}_{2}\right)$ on muscle $\mathrm{pH}$, total protein and myofibrillar protein solubility, and total myosin from fresh and frozen groups.

\begin{tabular}{l|ccc||ccc}
\hline \multirow{2}{*}{ Trait } & \multicolumn{3}{|c||}{ Fresh } & \multicolumn{3}{c}{ Frozen } \\
\cline { 2 - 5 } & No-soak & No $\mathrm{MgCl}_{2}$ & $\mathrm{MgCl}_{2}$ & No-soak & No $\mathrm{MgCl}_{2}$ & $\mathrm{MgCl}_{2}$ \\
\hline Muscle $\mathrm{pH}$ & $6.43^{\mathrm{x}}$ & $6.46^{\mathrm{y}}$ & $6.45^{\mathrm{y}}$ & $6.42^{\mathrm{a}}$ & $6.44^{\mathrm{b}}$ & $6.45^{\mathrm{b}}$ \\
Total protein solubility, $\mathrm{mg} / \mathrm{mL}$ & $5.22^{\mathrm{x}}$ & $6.01^{\mathrm{y}}$ & $5.79^{\mathrm{y}}$ & $4.36^{\mathrm{a}}$ & $5.10^{\mathrm{b}}$ & $4.94^{\mathrm{b}}$ \\
Myosin solubility, $\mu \mathrm{g} / \mathrm{mL}$ & $203^{\mathrm{x}}$ & $199^{\mathrm{x}}$ & $200^{\mathrm{x}}$ & $105^{\mathrm{a}}$ & $176^{\mathrm{c}}$ & $160^{\mathrm{b}}$ \\
Total myosin, $\mathrm{mg} / \mathrm{g} \mathrm{muscle}$ & $58.80^{\mathrm{x}}$ & $57.73^{\mathrm{x}}$ & $57.45^{\mathrm{x}}$ & $55.20^{\mathrm{a}}$ & $55.59^{\mathrm{a}}$ & $55.36^{\mathrm{a}}$ \\
Actin solubility, $\mu \mathrm{g} / \mathrm{mL}$ & $142^{\mathrm{x}}$ & $155^{\mathrm{y}}$ & $163^{\mathrm{z}}$ & $94^{\mathrm{a}}$ & $128^{\mathrm{b}}$ & $149^{\mathrm{c}}$ \\
\hline
\end{tabular}

${ }^{*}$ No-soak = Fillets without soaking treatment

${ }^{x y z}$ Means within fresh condition with different superscripts are different $(p<0.05)$.

${ }^{a b c}$ Means within frozen condition with different superscripts are different $(p<0.05)$. 
Table 4. Effect of $0.5 \%(\mathrm{w} / \mathrm{v})$ phosphate on surface hydrophobicity and total, free, and disulfide sulfhydryl (SH) content from fresh and frozen groups.

\begin{tabular}{|c|c|c|c|c|c|c|}
\hline \multirow[b]{2}{*}{ Trait } & \multicolumn{3}{|c|}{ Fresh } & \multicolumn{3}{|c|}{ Frozen } \\
\hline & No-soak* & No phosphate & Phosphate & No-soak & No phosphate & Phosphate \\
\hline Surface hydrophobicity & $3784^{x}$ & $4442^{x}$ & $4436^{x}$ & $76608^{c}$ & $60238^{b}$ & $56544^{a}$ \\
\hline Total SH, $\mu \mathrm{g} / \mathrm{g}$ protein & $105.05^{y}$ & $67.11^{x}$ & $71.05^{x}$ & $140.01^{b}$ & $125.67^{a}$ & $126.35^{a}$ \\
\hline Free $\mathrm{SH}, \mu \mathrm{g} / \mathrm{g}$ protein & $53.75^{x}$ & $54.39^{x}$ & $56.60^{x}$ & $76.90^{b}$ & $70.19^{a}$ & $69.94^{a}$ \\
\hline Disulfide $\mathrm{SH}, \mu \mathrm{g} / \mathrm{g}$ protein & $51.30^{y}$ & $14.46^{\mathrm{x}}$ & $12.72^{x}$ & $63.12^{b}$ & $56.41^{a}$ & $55.48^{a}$ \\
\hline
\end{tabular}

${ }^{\star}$ No-soak = Fillets without soaking treatment

${ }^{x y z}$ Means within fresh condition with different superscripts are different $(p<0.05)$.

${ }^{a b c}$ Means within frozen condition with different superscripts are different $(p<0.05)$. 
Table 5. Effect of $0.5 \%(\mathrm{w} / \mathrm{v})$ magnesium chloride $\left(\mathrm{MgCl}_{2}\right)$ on surface hydrophobicity and total and free sulfhydryl $(\mathrm{SH})$ content from fresh and frozen groups.

\begin{tabular}{|c|c|c|c|c|c|c|}
\hline \multirow[b]{2}{*}{ Trait } & \multicolumn{3}{|c|}{ Fresh } & \multicolumn{3}{|c|}{ Frozen } \\
\hline & No-soak* & No $\mathrm{MgCl}_{2}$ & $\mathrm{MgCl}_{2}$ & No-soak & No $\mathrm{MgCl}_{2}$ & $\mathrm{MgCl}_{2}$ \\
\hline Surface hydrophobicity & $3784^{x}$ & $4477^{x}$ & $4401^{x}$ & $76608^{b}$ & $59282^{a}$ & $57500^{a}$ \\
\hline Total $\mathrm{SH}, \mu \mathrm{g} / \mathrm{g}$ protein & $105.05^{y}$ & $69.70^{x}$ & $68.46^{x}$ & $140.01^{c}$ & $123.65^{\mathrm{a}}$ & $128.37^{b}$ \\
\hline Free $\mathrm{SH}, \mu \mathrm{g} / \mathrm{g}$ protein & $53.75^{x}$ & $54.26^{x}$ & $56.72^{x}$ & $76.90^{b}$ & $68.21^{a}$ & $71.92^{a}$ \\
\hline
\end{tabular}

${ }^{*}$ No-soak = Fillets without soaking treatment

${ }^{x y z}$ Means within fresh condition with different superscripts are different $(p<0.05)$.

${ }^{a b c}$ Means within frozen condition with different superscripts are different $(p<0.05)$. 
Table 6 . Effect of $0.5 \%(\mathrm{w} / \mathrm{v})$ phosphate on transition temperatures $\left(\mathrm{T}_{\mathrm{M}}\right)$ of myofibrillar proteins and endogenous protease activity from fresh and frozen groups.

\begin{tabular}{|c|c|c|c|c|c|c|}
\hline \multirow[b]{2}{*}{ Trait } & \multicolumn{3}{|c|}{ Fresh } & \multicolumn{3}{|c|}{ Frozen } \\
\hline & No-soak* & No phosphate & Phosphate & No-soak & No phosphate & Phosphate \\
\hline $\mathrm{T}_{\mathrm{M}}$ of myosin, ${ }^{\circ} \mathrm{C}$ & $47.98^{x}$ & $48.57^{x y}$ & $48.61^{y}$ & $46.67^{a}$ & $46.79^{a}$ & $48.14^{b}$ \\
\hline $\mathrm{T}_{\mathrm{M}}$ of actin, ${ }^{\circ} \mathrm{C}$ & $78.02^{x}$ & $78.14^{x y}$ & $78.40^{y}$ & $77.42^{a}$ & $78.01^{b}$ & $78.23^{b}$ \\
\hline Protease activity & $0.05^{x}$ & $0.10^{x}$ & $0.07^{x}$ & $0.06^{a}$ & $0.08^{a}$ & $0.07^{\mathrm{a}}$ \\
\hline
\end{tabular}

${ }^{*}$ No-soak = Fillets without soaking treatment

${ }^{x y z}$ Means within fresh condition with different superscripts are different $(p<0.05)$.

${ }^{a b c}$ Means within frozen condition with different superscripts are different $(p<0.05)$. 
Table 7. Effect of $0.5 \%(\mathrm{w} / \mathrm{v})$ magnesium chloride $\left(\mathrm{MgCl}_{2}\right)$ on transition temperatures $\left(\mathrm{T}_{\mathrm{M}}\right)$ of myofibrillar proteins and endogenous protease activity from fresh and frozen groups.

\begin{tabular}{l|ccc||ccc}
\hline \multirow{2}{*}{ Trait } & \multicolumn{3}{|c||}{ Fresh } & \multicolumn{3}{c}{ Frozen } \\
\cline { 2 - 6 } & No-soak & No MgCl & $\mathrm{MgCl}_{2}$ & No-soak & $\mathrm{No} \mathrm{MgCl}_{2}$ & $\mathrm{MgCl}_{2}$ \\
\hline $\mathrm{T}_{\mathrm{M}}$ of myosin, ${ }^{\circ} \mathrm{C}$ & $47.98^{\times}$ & $48.68^{\mathrm{x}}$ & $48.51^{\times}$ & $46.64^{\mathrm{a}}$ & $47.51^{\mathrm{a}}$ & $47.42^{\mathrm{a}}$ \\
$\mathrm{T}_{\mathrm{M}}$ of actin, ${ }^{\circ} \mathrm{C}$ & $78.02^{\mathrm{x}}$ & $78.43^{\mathrm{y}}$ & $78.11^{\mathrm{xy}}$ & $77.42^{\mathrm{a}}$ & $78.29^{\mathrm{c}}$ & $77.95^{\mathrm{b}}$ \\
Proteolytic activity & $0.05^{\mathrm{x}}$ & $0.08^{\mathrm{x}}$ & $0.06^{\mathrm{x}}$ & $0.06^{\mathrm{a}}$ & $0.07^{\mathrm{a}}$ & $0.07^{\mathrm{a}}$ \\
\hline
\end{tabular}

${ }^{*}$ No-soak = Fillets without soaking treatment

${ }^{x y z}$ Means within fresh condition with different superscripts are different $(p<0.05)$.

${ }^{a b c}$ Means within frozen condition with different superscripts are different $(p<0.05)$. 
Table 8. Effect of $0.5 \%(w / v)$ phosphate on muscle $L^{*}, a^{*}$, and $b^{*}$ values from fresh and frozen groups.

\begin{tabular}{l|ccc||ccc}
\hline \multirow{2}{*}{ Color } & \multicolumn{3}{|c||}{ Fresh } & \multicolumn{3}{c}{ Frozen } \\
\cline { 2 - 5 } & No-soak & No phosphate & Phosphate & No-soak & No phosphate & Phosphate \\
\hline $\mathrm{L}^{*}$ & $42.52^{\mathrm{x}}$ & $43.12^{\mathrm{y}}$ & $42.55^{\mathrm{x}}$ & $30.18^{\mathrm{a}}$ & $30.86^{\mathrm{b}}$ & $30.37^{\mathrm{a}}$ \\
$\mathrm{a}^{*}$ & $0.10^{\mathrm{x}}$ & $0.03^{\mathrm{x}}$ & $-0.03^{\mathrm{x}}$ & $-0.67^{\mathrm{a}}$ & $-0.87^{\mathrm{a}}$ & $-0.76^{\mathrm{a}}$ \\
$\mathrm{b}^{*}$ & $7.12^{\mathrm{x}}$ & $7.23^{\mathrm{x}}$ & $7.31^{\mathrm{x}}$ & $6.89^{\mathrm{b}}$ & $6.30^{\mathrm{a}}$ & $6.55^{\mathrm{ab}}$ \\
\hline
\end{tabular}

${ }^{*}$ No-soak = Fillets without soaking treatment

${ }^{x y z}$ Means within fresh condition with different superscripts are different $(p<0.05)$.

${ }^{a b c}$ Means within frozen condition with different superscripts are different $(p<0.05)$. 
Table 9. Effect of $0.5 \%(\mathrm{w} / \mathrm{v})$ magnesium chloride $\left(\mathrm{MgCl}_{2}\right)$ on muscle $\mathrm{L}^{*}, \mathrm{a}^{*}$, and $\mathrm{b}^{*}$ values from fresh and frozen groups.

\begin{tabular}{l|ccc||ccc}
\hline \multirow{2}{*}{ Color } & \multicolumn{3}{|c||}{ Fresh } & \multicolumn{3}{c}{ Frozen } \\
\cline { 2 - 6 } & No-soak & No MgCl & $\mathrm{MgCl}_{2}$ & No-soak & No $\mathrm{MgCl}_{2}$ & $\mathrm{MgCl}_{2}$ \\
\hline $\mathrm{L}^{*}$ & $42.52^{\mathrm{x}}$ & $42.30^{\times}$ & $42.99^{\times}$ & $30.18^{\mathrm{a}}$ & $30.39^{\mathrm{a}}$ & $30.17^{\mathrm{a}}$ \\
$\mathrm{a}^{*}$ & $0.10^{\mathrm{x}}$ & $0.01^{\mathrm{x}}$ & $-0.01^{\times}$ & $-0.67^{\mathrm{a}}$ & $-0.92^{\mathrm{a}}$ & $-0.71^{\mathrm{a}}$ \\
$\mathrm{b}^{*}$ & $7.12^{\mathrm{x}}$ & $7.50^{\mathrm{y}}$ & $7.04^{\mathrm{x}}$ & $6.89^{\mathrm{a}}$ & $6.59^{\mathrm{a}}$ & $6.52^{\mathrm{a}}$ \\
\hline
\end{tabular}

${ }^{*}$ No-soak = Fillets without soaking treatment

${ }^{x y z}$ Means within fresh condition with different superscripts are different $(p<0.05)$.

${ }^{a b c}$ Means within frozen condition with different superscripts are different $(p<0.05)$. 
Table 10. Effect of $0.5 \%(\mathrm{w} / \mathrm{v})$ phosphate on brine uptake, fillet and mince cook yield, cooked $\mathrm{pH}$, and total and waterphase salt content from fresh and frozen groups.

\begin{tabular}{|c|c|c|c|c|c|c|}
\hline \multirow[b]{2}{*}{ Trait } & \multicolumn{3}{|c|}{ Fresh } & \multicolumn{3}{|c|}{ Frozen } \\
\hline & No-soak $^{*}$ & No phosphate & Phosphate & No-soak & No phosphate & Phosphate \\
\hline Brine uptake, \% & $1.84^{y}$ & $0.11^{x}$ & $0.14^{x}$ & $-0.46^{a}$ & $-0.28^{a}$ & $-0.37^{a}$ \\
\hline Fillet cook yield, \% & $71.29^{y}$ & $68.68^{x}$ & $68.70^{x}$ & $67.84^{a}$ & $68.38^{b}$ & $68.57^{b}$ \\
\hline Cook pH & $6.47^{x y}$ & $6.46^{x}$ & $6.48^{y}$ & $6.49^{b}$ & $6.47^{a}$ & $6.50^{b}$ \\
\hline
\end{tabular}

*No-soak = Fillets without soaking treatment

${ }^{x y z}$ Means within fresh condition with different superscripts are different $(p<0.05)$.

${ }^{a b c}$ Means within frozen condition with different superscripts are different $(p<0.05)$. 
Table 11. Effect of $0.5 \%(\mathrm{w} / \mathrm{v})$ magnesium chloride $\left(\mathrm{MgCl}_{2}\right)$ on brine uptake, mince and fillet cook yield, cooked $\mathrm{pH}$, and total and water-phase salt content from fresh and frozen groups.

\begin{tabular}{|c|c|c|c|c|c|c|}
\hline \multirow[b]{2}{*}{ Color } & \multicolumn{3}{|c|}{ Fresh } & \multicolumn{3}{|c|}{ Frozen } \\
\hline & No-soak* $^{*}$ & No $\mathrm{MgCl}_{2}$ & $\mathrm{MgCl}_{2}$ & No-soak & No $\mathrm{MgCl}_{2}$ & $\mathrm{MgCl}_{2}$ \\
\hline Brine uptake, \% & $1.84^{y}$ & $0.06^{x}$ & $0.19^{x}$ & $-0.46^{a}$ & $-0.37^{a}$ & $-0.27^{a}$ \\
\hline Mince cook yield, \% & $98.87^{y}$ & $98.68^{x}$ & $98.79^{x}$ & $98.63^{a}$ & $98.65^{b}$ & $98.64^{b}$ \\
\hline Fillet cook yield, \% & $71.29^{y}$ & $69.70^{x}$ & $69.30^{x}$ & $67.84^{\mathrm{a}}$ & $68.73^{b}$ & $68.53^{b}$ \\
\hline Cooked pH & $6.47^{y}$ & $6.48^{y}$ & $6.45^{x}$ & $6.49^{a}$ & $6.48^{a}$ & $6.50^{a}$ \\
\hline Salt content, \% & $2.58^{x}$ & $2.63^{x}$ & $2.69^{x}$ & $2.97^{a}$ & $2.86^{a}$ & $2.93^{a}$ \\
\hline Water-phase salt content, \% & $3.81^{x}$ & $3.83^{x}$ & $3.93^{x}$ & $4.16^{a}$ & $4.10^{a}$ & $4.22^{a}$ \\
\hline
\end{tabular}

${ }^{*}$ No-soak = Fillets without soaking treatment

${ }^{x y z}$ Means within fresh condition with different superscripts are different $(p<0.05)$.

${ }^{a b c}$ Means within frozen condition with different superscripts are different $(p<0.05)$. 
Table 12. Effect of $0.5 \%(\mathrm{w} / \mathrm{v})$ phosphate on hardness and cohesiveness of cooked mince and fillet shear force from fresh and frozen groups.

\begin{tabular}{|c|c|c|c|c|c|c|}
\hline \multirow[b]{2}{*}{ Texture } & \multicolumn{3}{|c|}{ Fresh } & \multicolumn{3}{|c|}{ Frozen } \\
\hline & No-soak* & No phosphate & Phosphate & No-soak & No phosphate & Phosphate \\
\hline Hardness & $3384^{y}$ & $3076^{x}$ & $2996^{x}$ & $2337^{a}$ & $2934^{b}$ & $3126^{b}$ \\
\hline Cohesiveness & $65.74^{y}$ & $57.80^{x}$ & $57.95^{x}$ & $57.61^{a}$ & $62.66^{b}$ & $62.81^{b}$ \\
\hline Fillet shear force & $569^{x}$ & $549^{x}$ & $582^{x}$ & $444^{a}$ & $450^{a}$ & $462^{a}$ \\
\hline
\end{tabular}

${ }^{\star}$ No-soak = Fillets without soaking treatment

${ }^{x y z}$ Means within fresh condition with different superscripts are different $(p<0.05)$.

${ }^{a b c}$ Means within frozen condition with different superscripts are different $(p<0.05)$. 
Table 13. Effect of $0.5 \%(\mathrm{w} / \mathrm{v})$ magnesium chloride $\left(\mathrm{MgCl}_{2}\right)$ on hardness and cohesiveness of cooked mince and fillet shear force from fresh and frozen groups.

\begin{tabular}{l|ccc||ccc}
\hline \multirow{2}{*}{ Texture } & \multicolumn{3}{|c||}{ Fresh } & \multicolumn{3}{c}{ Frozen } \\
\cline { 2 - 5 } & No-soak & No MgCl & $\mathrm{MgCl}_{2}$ & No-soak & $\mathrm{No} \mathrm{MgCl}_{2}$ & $\mathrm{MgCl}_{2}$ \\
\hline Hardness & $3384^{\mathrm{y}}$ & $3041^{\mathrm{x}}$ & $3030^{\times}$ & $2337^{\mathrm{a}}$ & $3109^{\mathrm{b}}$ & $2951^{\mathrm{b}}$ \\
Cohesiveness & $65.74^{\mathrm{y}}$ & $57.85^{\mathrm{x}}$ & $57.90^{\mathrm{x}}$ & $57.61^{\mathrm{a}}$ & $62.34^{\mathrm{b}}$ & $63.12^{\mathrm{b}}$ \\
Fillet shear force & $569^{\mathrm{x}}$ & $569^{\mathrm{x}}$ & $562^{\mathrm{x}}$ & $444^{\mathrm{a}}$ & $446^{\mathrm{a}}$ & $446^{\mathrm{a}}$ \\
\hline
\end{tabular}

${ }^{*}$ No-soak = Fillets without soaking treatment

${ }^{x y z}$ Means within fresh condition with different superscripts are different $(p<0.05)$.

${ }^{a b c}$ Means within frozen condition with different superscripts are different $(p<0.05)$. 
Table 14. Effect of cryoprotectant on proximate composition of brined fillets produced from fresh and frozen groups.

\begin{tabular}{|c|c|c|c|c|c|c|c|c|}
\hline \multirow[b]{2}{*}{ Composition, \% } & \multicolumn{4}{|c|}{ Fresh } & \multicolumn{4}{|c|}{ Frozen } \\
\hline & No-soak* & Water & SL & $\mathrm{S} / \mathrm{S}$ & No-soak & Water & SL & $\mathrm{S} / \mathrm{S}$ \\
\hline Moisture & $72.89^{x}$ & $72.13^{x}$ & $73.50^{x}$ & $73.46^{x}$ & $74.38^{a}$ & $74.05^{a}$ & $74.34^{a}$ & $74.86^{a}$ \\
\hline Fat & $1.74^{x y}$ & $1.78^{x y}$ & $2.23^{y}$ & $1.55^{x}$ & $2.13^{a}$ & $1.81^{\mathrm{a}}$ & $1.98^{a}$ & $1.66^{a}$ \\
\hline Protein & $18.68^{x}$ & $19.09^{y}$ & $18.59^{x}$ & $19.76^{z}$ & $19.47^{\mathrm{a}}$ & $19.03^{a}$ & $19.04^{a}$ & $18.93^{a}$ \\
\hline Ash & $2.04^{x}$ & $2.11^{x}$ & $2.03^{x}$ & $2.08^{x}$ & $2.38^{a}$ & $2.15^{\mathrm{a}}$ & $2.22^{a}$ & $2.20^{a}$ \\
\hline
\end{tabular}

${ }^{*}$ No-soak = Fillets without soaking treatment

Water $=$ Fillets soaked in water

$\mathrm{SL}=1 \%(\mathrm{w} / \mathrm{v})$ sodium lactate solution

$\mathrm{S} / \mathrm{S}=8 \%(\mathrm{w} / \mathrm{v})$ sucrose/ sorbitol $(1: 1 \mathrm{w} / \mathrm{w})$ solution

${ }^{x y z}$ Means within fresh condition with different superscripts are different $(p<0.05)$.

${ }^{a b c}$ Means within frozen condition with different superscripts are different $(p<0.05)$. 
Table 15. Effect of cryoprotectant on proximate composition of smoked fillets produced from fresh and frozen groups.

\begin{tabular}{l|cccc||cccc}
\hline \multirow{2}{*}{ Composition, \% } & \multicolumn{5}{|c||}{ Fresh } & \multicolumn{4}{c}{ Frozen } \\
\cline { 2 - 8 } & No-soak & Water & SL & S/S & No-soak & Water & SL & S/S \\
\hline Moisture & $64.02^{y}$ & $64.13^{y}$ & $63.47^{y}$ & $62.40^{x}$ & $63.36^{a}$ & $63.66^{a}$ & $64.01^{a}$ & $63.47^{a}$ \\
Fat & $5.95^{y}$ & $6.79^{z}$ & $6.01^{y}$ & $5.14^{x}$ & $4.63^{a}$ & $5.00^{a}$ & $6.06^{b}$ & $5.21^{a}$ \\
Protein & $27.53^{x}$ & $27.27^{x}$ & $27.21^{x}$ & $27.70^{x}$ & $26.59^{\text {abc }}$ & $25.81^{a}$ & $26.89^{c}$ & $26.37^{b}$ \\
Ash & $2.94^{x}$ & $3.09^{x}$ & $2.87^{x}$ & $3.09^{x}$ & $3.44^{a}$ & $3.19^{a}$ & $3.50^{a}$ & $3.26^{a}$ \\
\hline
\end{tabular}

${ }^{*}$ No-soak = Fillets without soaking treatment

Water $=$ Fillets soaked in water

$\mathrm{SL}=1 \%(\mathrm{w} / \mathrm{v})$ sodium lactate solution

$\mathrm{S} / \mathrm{S}=8 \%(\mathrm{w} / \mathrm{v})$ sucrose/ sorbitol $(1: 1 \mathrm{w} / \mathrm{w})$ solution

${ }^{x y z}$ Means within fresh condition with different superscripts are different $(p<0.05)$.

${ }^{a b c}$ Means within frozen condition with different superscripts are different $(p<0.05)$. 
Table 16. Effect of $0.5 \%(\mathrm{w} / \mathrm{v})$ phosphate on proximate composition of brined fillets produced from fresh and frozen groups.

\begin{tabular}{l|ccc||ccc}
\hline \multirow{2}{*}{ Composition, \% } & \multicolumn{3}{|c||}{ Fresh } & \multicolumn{3}{c}{ Frozen } \\
\cline { 2 - 5 } & No-soak & No phosphate & Phosphate & No-soak & No phosphate & Phosphate \\
\hline Moisture & $72.89^{\times}$ & $72.44^{\times}$ & $72.95^{\mathrm{x}}$ & $74.38^{\mathrm{a}}$ & $75.14^{\mathrm{a}}$ & $73.70^{\mathrm{a}}$ \\
Fat & $1.74^{\mathrm{x}}$ & $1.82^{\mathrm{x}}$ & $1.89^{\mathrm{x}}$ & $2.13^{\mathrm{a}}$ & $1.79^{\mathrm{a}}$ & $1.85^{\mathrm{a}}$ \\
Protein & $18.68^{\mathrm{x}}$ & $19.26^{\mathrm{x}}$ & $19.04^{\mathrm{x}}$ & $19.47^{\mathrm{a}}$ & $19.07^{\mathrm{a}}$ & $18.93^{\mathrm{a}}$ \\
Ash & $2.04^{\mathrm{x}}$ & $2.13^{\mathrm{x}}$ & $2.03^{\mathrm{x}}$ & $2.38^{\mathrm{a}}$ & $2.17^{\mathrm{a}}$ & $2.21^{\mathrm{a}}$ \\
\hline
\end{tabular}

${ }^{*}$ No-soak = Fillets without soaking treatment

${ }^{x y z}$ Means within fresh condition with different superscripts are different $(p<0.05)$.

${ }^{a b c}$ Means within frozen condition with different superscripts are different $(p<0.05)$. 
Table 17. Effect of $0.5 \%(\mathrm{w} / \mathrm{v})$ phosphate on proximate composition of cooked fillets produced from fresh and frozen groups.

\begin{tabular}{l|ccc||ccc}
\hline \multirow{2}{*}{ Composition, \% } & \multicolumn{3}{|c||}{ Fresh } & \multicolumn{3}{c}{ Frozen } \\
\cline { 2 - 5 } & No-soak & No phosphate & Phosphate & No-soak & No phosphate & Phosphate \\
\hline Moisture & $64.02^{\mathrm{y}}$ & $63.42^{\mathrm{x}}$ & $63.81^{\mathrm{xy}}$ & $63.35^{\mathrm{a}}$ & $63.42^{\mathrm{ab}}$ & $63.81^{\mathrm{b}}$ \\
Fat & $5.95^{\mathrm{x}}$ & $5.44^{\mathrm{x}}$ & $5.94^{\mathrm{x}}$ & $4.63^{\mathrm{a}}$ & $5.44^{\mathrm{b}}$ & $6.10^{\mathrm{b}}$ \\
Protein & $27.53^{\mathrm{x}}$ & $27.59^{\mathrm{x}}$ & $27.19^{\mathrm{x}}$ & $26.59^{\mathrm{a}}$ & $26.32^{\mathrm{a}}$ & $26.38^{\mathrm{a}}$ \\
Ash & $2.29^{\mathrm{x}}$ & $2.93^{\mathrm{x}}$ & $3.11^{\mathrm{x}}$ & $3.44^{\mathrm{a}}$ & $3.19^{\mathrm{a}}$ & $3.27^{\mathrm{a}}$ \\
\hline
\end{tabular}

${ }^{*}$ No-soak = Fillets without soaking treatment

${ }^{x y z}$ Means within fresh condition with different superscripts are different $(p<0.05)$.

${ }^{a b c}$ Means within frozen condition with different superscripts are different $(p<0.05)$. 
Table 18. Effect of $0.05 \%(\mathrm{w} / \mathrm{v})$ magnesium chloride $\left(\mathrm{MgCl}_{2}\right)$ on proximate composition of brined fillets produced from fresh and frozen groups.

\begin{tabular}{|c|c|c|c|c|c|c|}
\hline \multirow[b]{2}{*}{ Composition, \% } & \multicolumn{3}{|c|}{ Fresh } & \multicolumn{3}{|c|}{ Frozen } \\
\hline & No-soak* & No $\mathrm{MgCl}_{2}$ & $\mathrm{MgCl}_{2}$ & No-soak & No $\mathrm{MgCl}_{2}$ & $\mathrm{MgCl}_{2}$ \\
\hline Moisture & $72.89^{x}$ & $72.56^{x}$ & $72.83^{x}$ & $74.38^{a}$ & $73.54^{\mathrm{a}}$ & $75.29^{\circ}$ \\
\hline Fat & $1.74^{x}$ & $1.94^{x}$ & $1.77^{x}$ & $2.13^{a}$ & $1.69^{a}$ & $1.95^{\mathrm{a}}$ \\
\hline Protein & $18.68^{x}$ & $18.98^{x}$ & $19.31^{x}$ & $19.47^{\mathrm{a}}$ & $19.06^{a}$ & $18.94^{\circ}$ \\
\hline Ash & $2.04^{x}$ & $2.08^{x}$ & $2.07^{x}$ & $2.38^{\mathrm{a}}$ & $2.19^{a}$ & $2.19^{a}$ \\
\hline
\end{tabular}

${ }^{*}$ No-soak = Fillets without soaking treatment

${ }^{x y z}$ Means within fresh condition with different superscripts are different $(p<0.05)$.

${ }^{\mathrm{abc}}$ Means within frozen condition with different superscripts are different $(\mathrm{p}<0.05)$. 
Table 19. Effect of $0.05 \%(\mathrm{w} / \mathrm{v})$ magnesium chloride $\left(\mathrm{MgCl}_{2}\right)$ on proximate composition of cooked fillets produced from fresh and frozen groups.

\begin{tabular}{|c|c|c|c|c|c|c|}
\hline \multirow[b]{2}{*}{ Composition, \% } & \multicolumn{3}{|c|}{ Fresh } & \multicolumn{3}{|c|}{ Frozen } \\
\hline & No-soak* & No $\mathrm{MgCl}_{2}$ & $\mathrm{MgCl}_{2}$ & No-soak & No $\mathrm{MgCl}_{2}$ & $\mathrm{MgCl}_{2}$ \\
\hline Moisture & $64.02^{y}$ & $63.50^{x}$ & $63.52^{x}$ & $63.36^{\mathrm{a}}$ & $63.62^{\mathrm{ab}}$ & $63.52^{b}$ \\
\hline Fat & $5.95^{x}$ & $5.40^{x}$ & $5.37^{x}$ & $4.63^{a}$ & $6.15^{b}$ & $5.89^{b}$ \\
\hline Protein & $27.53^{x}$ & $27.40^{x}$ & $27.38^{x}$ & $26.59^{a}$ & $26.27^{\mathrm{a}}$ & $26.44^{2}$ \\
\hline Ash & $2.29^{x}$ & $3.00^{x}$ & $3.04^{x}$ & $3.44^{\mathrm{a}}$ & $3.24^{\mathrm{a}}$ & $3.23^{a}$ \\
\hline
\end{tabular}

${ }^{*}$ No-soak = Fillets without soaking treatment

${ }^{x y z}$ Means within fresh condition with different superscripts are different $(p<0.05)$.

${ }^{\mathrm{abc}}$ Means within frozen condition with different superscripts are different $(\mathrm{p}<0.05)$. 


\section{APPENDICES}




\section{APPENDIX 1}

\section{PRELIMINARY STUDY}

\section{CHEMICAL AND PHYSICAL CHANGES}

\section{IN SMOKED RAINBOW TROUT, Oncorhynchus mykiss, ASSOCIATED WITH FROZEN STORAGE}

\section{Abstract}

Fish muscle is particularly susceptible to the deleterious effects of frozen storage. Freeze-induced protein denaturation in raw material affects proteinprotein and protein-water interactions that, in turn affect product texture. The objective of this study was to determine the effect of frozen storage at $-20^{\circ} \mathrm{C}$ on the quality of smoked rainbow trout, Oncorhynchus mykiss, fillets prepared from fresh fillets and fillets frozen for $78 \mathrm{~d}$. The experimental design was a $2 \times 2 \times 4$ factorial, incomplete block design with fillet storage (fresh and frozen) as the main plot. Eight treatment combinations of two brine concentrations (8.7 and $17.4 \% \mathrm{w} / \mathrm{v}$ sodium chloride) and four brining times $(30,60,90$, and $120 \mathrm{~min})$ were the sub-plots. Treatments were replicated on three separate days and nested within fillet storage. Brined fillets were smoked in microprocessorcontrolled smokeoven to an internal temperature of $65.5^{\circ} \mathrm{C}$ and held for $50 \mathrm{~min}$. A fish mince was also prepared from each treatment and used for determining texture. Frozen storage at $-20^{\circ} \mathrm{C}$ for $78 \mathrm{~d}$ increased $(\mathrm{p}<0.05)$ total soluble protein and decreased $(p<0.05)$ myosin and actin solubility. Use of frozen fillets reduced hardness of cooked mince and shear force of smoked fillets by $86 \%$ and 
$55 \%$, respectively, and it tended to decrease cohesiveness. Fat content of smoked products prepared from frozen fillets was decreased $(p<0.05)$.

\section{Introduction}

Frozen storage is an excellent preservation method for maintaining chemical and microbiological stability of fresh foods and food products without causing major changes in size, shape, texture, color, and flavor. However, deteriorations in food texture resulting from biochemical, enzymatic, and functional changes in proteins are problems associated with formation of ice crystals, which is an integral part of the freezing process. Ice crystals can penetrate fragile membranes causing release of enclosed contents and changes in the microenvironment of food tissue. Freeze-induced protein denaturation and related functionality losses are commonly observed in frozen meat especially in fish species.

Three accepted theories are presented to explain alterations in the protein microenvironment that cause protein denaturation during freezing and frozen storage. They are: 1) an increase in solute concentration, 2) dehydration of the cell, and 3) autoxidative changes that alter the balance of protein-protein and protein-water interactions. Recent studies have demonstrated that oxidative reactions such as lipid oxidation are involved in denaturation and deterioration in functionality attributes of muscle protein by causing cross-linking between protein and lipid oxidation products. The objective of this study was determined the effect of freezing and frozen storage at $-20^{\circ} \mathrm{C}$ on smoked trout produced with varying brine concentrations and brining times. 


\section{Materials and Methods}

Trout were harvested and brought to the processing laboratory to be eviscerated and filleted. Fresh fillets were soaked in a separate container containing 8.7 or $17.4 \%(\mathrm{w} / \mathrm{v})$ sodium chloride for $30,60,90$, or $120 \mathrm{~min}$ at $3^{\circ} \mathrm{C}$. For frozen storage, fillets were vacuum packed in polyethylene bags and stored for $78 \mathrm{~d}$ at $-20^{\circ} \mathrm{C}$. Frozen fillets were thawed overnight at $3^{\circ} \mathrm{C}$ before brining.

Thermal and gel processing, and chemical and physical analyses were explained as in the materials and methods section of Chapter 1.

A $2 \times 2 \times 4$ factorial, incomplete block design was conducted with fillet storage (fresh and frozen) as the main plot. Eight treatment combinations of two brine concentrations ( 8.7 and $17.4 \% \mathrm{w} / \mathrm{v}$ sodium chloride) and four brining time $(30,60,90$ and $120 \mathrm{~min})$ were the sub-plots. Treatments were replicated on separate days and nested within fillet storage. Data were analyzed using the General Linear Model (GLM) procedure of SAS (SAS Institute, Inc., 1989) to establish main and interaction effects. Means were separated using the PDIFF of the Ismeans procedure.

\section{Results and discussion}

Frozen storage at $-20^{\circ} \mathrm{C}$ for 78 days increased $(p<0.05)$ total soluble protein and decreased $(p<0.05)$ myosin and actin solubility. The increase in protein solubility after frozen storage might be caused by modifications of chemical groups especially sulfhydryls. Decreased myosin and actin solubility may be due to increased protein-protein interactions. Use of frozen fillets reduced hardness of cooked mince and shear force of smoked fillets by $86 \%$ and 
$55 \%$, respectively, and it tended to decrease cohesiveness. Fat content of smoked products prepared from frozen fillets decreased $(p<0.05)$ because of decreased structural integrity and reduced ability to retain fat. Cook yield of products produced from frozen fillets was slightly lower than that of fresh fillets. This decreased cook yield may be due to decreased cooked fat.

\section{Conclusions}

Frozen storage resulted in lower myosin solubility that, in turn, negatively affected product texture. 
Effect of $78-\mathrm{d}$ frozen storage at $20^{\circ} \mathrm{C}$ on brined fillet characteristics

\begin{tabular}{lcc}
\hline Trait & Fresh & Frozen \\
\hline Brined $\mathrm{pH}$ & $6.37^{\mathrm{a}}$ & $6.39^{\mathrm{a}}$ \\
Brine uptake, \% & $-0.22^{\mathrm{a}}$ & $-0.21^{\mathrm{a}}$ \\
Total soluble proteins, $\mathrm{mg} / \mathrm{mL}$ & $7.31^{\mathrm{a}}$ & $9.78^{\mathrm{b}}$ \\
Myosin solubility, $\mu \mathrm{g} / \mathrm{mL}$ & $88.22^{\mathrm{b}}$ & $48.60^{\mathrm{a}}$ \\
Actin solubility, $\mu \mathrm{g} / \mathrm{mL}$ & $71.11^{\mathrm{b}}$ & $28.02^{\mathrm{a}}$ \\
Moisture, \% & $74.06^{\mathrm{a}}$ & $74.90^{\mathrm{a}}$ \\
Fat, \% & $1.06^{\mathrm{a}}$ & $1.48^{\mathrm{a}}$ \\
Protein, \% & $18.75^{\mathrm{a}}$ & $17.68^{\mathrm{a}}$ \\
\hline
\end{tabular}

${ }^{a b}$ Means within each row with different superscripts are different $(p<0.05)$. 
Effect of $78-d$ frozen storage at $20^{\circ} \mathrm{C}$ on cooked fillet characteristics

\begin{tabular}{lcc}
\hline Trait & Fresh & Frozen \\
\hline Cooked pH & $6.51^{\mathrm{a}}$ & $6.56^{\mathrm{a}}$ \\
Fillet cook yield, \% & $67.04^{\mathrm{a}}$ & $65.08^{\mathrm{a}}$ \\
Salt content, \% & $3.54^{\mathrm{a}}$ & $3.81^{\mathrm{a}}$ \\
Water-phase salt content, \% & $5.92^{\mathrm{a}}$ & $6.01^{\mathrm{a}}$ \\
Hardness of mince, g & $3398^{\mathrm{b}}$ & $466^{\mathrm{a}}$ \\
Cohesiveness of mince, \% & $46.61^{\mathrm{a}}$ & $40.84^{\mathrm{a}}$ \\
Fillet shear force, g & $1637^{\mathrm{b}}$ & $730^{\mathrm{a}}$ \\
Moisture, \% & $57.31^{\mathrm{a}}$ & $59.95^{\mathrm{a}}$ \\
Fat, \% & $8.80^{\mathrm{b}}$ & $6.26^{\mathrm{a}}$ \\
Protein, \% & $28.44^{\mathrm{a}}$ & $27.49^{\mathrm{a}}$ \\
\hline
\end{tabular}

${ }^{a b}$ Means within each row with different superscripts are different $(p<0.05)$. 


\section{APPENDIX 2}

\section{SOLUBLE MYOFIBRILLAR PROTEINS}

\section{Sodium dodecyl sulfate, polyacrylamide gel electrophoresis (SDS-PAGE)}

A vertical slab gel system (Hoefer Scientific Instruments; San Francisco, CA) was used to prepare $1.5 \mathrm{~mm}$-thick gels. Appropriate quantities of protein extract, sample buffer (0.7 M 2-mercaptoethanol; 3\% SDS; $0.05 \mathrm{M}$ tris buffer, $\mathrm{pH}$ 6.8) and $10 \%$ bromophenol blue: glycerol were combined to give a final protein concentration of $1 \mathrm{mg} / \mathrm{mL}$. Twenty microliters of the standardized sample were loaded in alternating wells of a $3 \%$ stacking gel, and sample buffer was loaded in empty wells to minimize band diffusion. A $15 \%$ bis-acrylamide resolving gel was used to separate protein bands. Electrophoresis was conducted at a constant current of $20 \mathrm{~mA}$ per slab until the tracking dye reached the resolving gel, and the current was then increased to $30 \mathrm{~mA}$ per slab. Electrophoresis proceeded until the marker dye was $4 \mathrm{~cm}$ from the bottom of the gel. Gels were fixed in $10 \%(\mathrm{w} / \mathrm{v})$ trichloroacetic acid (TCA) for $20 \mathrm{~min}$, stained in a $0.05 \%(\mathrm{w} / \mathrm{v})$ Coomassive brilliant blue G-250 (Eastman Kodak Co.; Rochester, NY), 50\% (v/v) methanol, and $9.2 \%(\mathrm{v} / \mathrm{v})$ glacial acetic acid solution for $4 \mathrm{~h}$. Gels were subsequently destained in a solution containing $10 \%(\mathrm{v} / \mathrm{v})$ methanol and $7.5 \%$ (v/v) glacial acetic acid until the background was clear. Destaining procedures for all gels were standardized. Ten $\mu \mathrm{L}$ of high (212-40 kDa) and low (31-2.5 kDa) molecular weight marker (Sigma Chemical Co.; St. Louis, MO) were loaded on the left side of each gel, and $5 \mu \mathrm{g}$ each of an actin and myosin standard (Sigma Chemical Co.; St. Louis, MO) were loaded on the right side of each gel. All other 
reagents used were analytical grade. Gel image was acquired under a video camera (Alpha Innotech Corporation; San Leandro, CA) using Fluochem ${ }^{\mathrm{TM}}$ program. Individual bands of myosin and actin were magnified at $2 x$. Soluble myosin and actin concentration ( $\mu \mathrm{g} / \mathrm{mL}$ extracted solution) were calculated according to densitometer reading compared to standards $\mathrm{x}$ (50; dilution factor). 


\section{APPENDIX 3}

\section{ALIPHATIC PROTEIN SURFACE HYDROPHOBICITY $\left(\mathbf{S}_{0}\right)$}

Fluorescent values change day-to-day and relative fluorescent intensity $(\mathrm{RFI})$ is temperature dependent; therefore, store samples under refrigeration and read RFI at a constant temperature.

Equipment spectrofluorophotometer (Model RF5000U, Shimadzu Corp., Japan)

\section{Chemicals}

1. $0.0036 \mathrm{M}$ cis-parinaric acid (CPA; Molecular Probes, Inc.; Eugene, OR): $9.94 \mathrm{mg} \mathrm{CPA}$ and $100.0 \mathrm{mg}$ butylhydroxyanisole (BHA; Sigma-Aldrich; St. Louis, MO) bring to $10 \mathrm{~mL}$ volume with absolute ethanol. (BHA is added as a preservative since CPA is highly susceptible to autoxidation.)

2. Buffer solution: $2.56 \%$ sodium chloride solution, $\mathrm{pH} 6.5$ (extracting solution)

\section{Method}

1. Prepare serial dilutions of protein with buffer solution from $0.01 \%$ to $0.05 \%$. The final volume of solution is $2 \mathrm{~mL}$.

2. Adjust zero RFI with $2 \mathrm{~mL}$ of buffer solution.

3. Add $2 \mathrm{~mL}$ of diluted sample to cuvette and read RFI at the peak value, using excitation and emission wavelength 325 and $420 \mathrm{~nm}$, respectively.

4. Add $10 \mu \mathrm{L}$ of $0.0036 \mathrm{M} \mathrm{CPA}$ and gently mix with plastic dropper.

5. Fluorescence is measured before (protein blank) and after adding CPA. Net RFI is defined as RFI of solution containing probe minus RFI of solution prior probe addition (protein blank). 
6. Slope of the curve $\left(\mathrm{S}_{0}\right)$ between net RFI and protein concentration is analyzed by linear regression. 


\section{APPENDIX 4}

\section{FREE AND TOTAL SULFHYDRYL CONTENT}

\section{Equipments}

1. Spectrophotometer (Model Spec20-D, Fisher Scientific Co.; Pittsburgh, $\mathrm{PA})$

2. Refrigerated centrifuge (Fisher Scientific Co.; Pittsburgh, PA)

\section{Chemicals}

1. Ellman's reagent (Sigma-Aldrich; St. Louis, MO): 5,5'-dithiobis-2nitrobenzoic acid (4 mg/mL Tris-glycine-EDTA).

2. Tris-glycine-EDTA buffer ( $\mathrm{pH} 8$ ): $10.4146 \mathrm{~g}$ Tris ( $\mathrm{MW}=121.1 \mathrm{~g} / \mathrm{mole}$ ), $6.7563 \mathrm{~g}$ glycine $(\mathrm{MW}=75.07 \mathrm{~g} / \mathrm{mole}), 1.4890 \mathrm{~g}$ EDTA $(\mathrm{MW}=372.24$ $\mathrm{g} / \mathrm{mole})$. Bring to $1000 \mathrm{~mL}$ with deionized, distilled water.

3. Tris-glycine-EDTA buffer-8 $\mathrm{M}$ urea $(\mathrm{pH}$ 8): $480.48 \mathrm{~g}$ urea $(\mathrm{MW}=60.06$ $\mathrm{g} / \mathrm{mole})$. All other reagents and amounts are the same as "2".

4. Tris-glycine-EDTA buffer-10 M urea-4\% $\beta$-mercaptoethanol: $600.60 \mathrm{~g}$ urea, $40.0 \mathrm{~mL}$ 2-mercaptoethanol. All other reagents and amounts are same as "2".

5. $24 \%$ Trichloroacetic acid (TCA): $120 \mathrm{~g} \mathrm{TCA}$ in $500 \mathrm{~mL}$ distilled water.

6. $12 \%$ TCA: $60 \mathrm{~g} \mathrm{TCA}$ in $500 \mathrm{~mL}$ distilled water.

\section{Method for determine free sulfhydryl content (free SH)}

1. Dilute protein solution 20 fold with Tris-glycine-EDTA buffer: for protein extracts containing $3-8 \mathrm{mg} / \mathrm{mL}$, dilute $0.5 \mathrm{~mL}$ of extract with $9.5 \mathrm{~mL}$ buffer in order to avoid protein precipitation if ionic strength is too low. 
2. Pipett $3 \mathrm{~mL}$ of diluted sample into cuvette and read absorbance at $412 \mathrm{~nm}$ and this denotes the sample blank.

3. Add $0.03 \mathrm{~mL}$ of Ellman's reagent and read absorbance after $30 \mathrm{~min}$.

4. Prepare reagent blank by pipetting $0.03 \mathrm{~mL}$ of Ellman's reagent into 3.0 $\mathrm{mL}$ of Tris-glycine-EDTA buffer.

\section{Method for determine total sulfhydryls content (total SH)}

1. Dilute protein solution 20 fold with Tris-glycine-EDTA buffer-10 M urea, 4\% 2-mercaptoethanol: dilute $0.5 \mathrm{~mL}$ of extract with $9.5 \mathrm{~mL}$ buffer.

2. Incubate at room temperature for $1 \mathrm{~h}$.

3. Precipitate protein with equal volume $(10 \mathrm{~mL})$ of $24 \%$ TCA and hold for $1 \mathrm{~h}$.

4. Centrifuge at $5000 \mathrm{xg}$ for $10 \mathrm{~min}$.

5. Pellets are resuspended twice with equal volume $(10 \mathrm{~mL})$ of $12 \%$ TCA and centrifuge at $5000 \mathrm{~g}$ for $10 \mathrm{~min}$.

6. Pellets are dissolved in equal volume $(10 \mathrm{~mL})$ of Tris-glycine-EDTA buffer$8 \mathrm{M}$ urea.

7. Pipet $3 \mathrm{~mL}$ of diluted sample into cuvette and read absorbance at $412 \mathrm{~nm}$ and this denotes the sample blank.

8. Add $0.05 \mathrm{~mL}$ of Ellman's reagent and read absorbance after $30 \mathrm{~min}$.

9. Prepare reagent blank by pipetting $0.05 \mathrm{~mL}$ of Ellman's reagent into 3.0 $\mathrm{mL}$ of Tris-glycine-EDTA buffer-8 $\mathrm{M}$ urea. 


\section{Calculations}

$\mu \mathrm{MSH} / \mathrm{g}$ protein $=\left(73.53 \times \mathrm{A}_{412} \times \mathrm{D}\right) / \mathrm{C}$

$73.53=10^{6} /\left(1.36 \times 10^{4}\right): 1.36 \times 10^{4}$ is the molar absorbtivity of Ellman's
reagent and $10^{6}$ is the conversion of mole $/ \mathrm{mg}$ to $\mu \mathrm{M} / \mathrm{g}$
$\mathrm{A}_{412}=$ net absorbance after correcting for reagent and sample blanks
$\mathrm{C}=$ sample protein concentration $(\mathrm{mg} / \mathrm{mL})$
$\mathrm{D}=$ dilution factor $(20)$

Total $\mathrm{SH}=$ Free $\mathrm{SH}+\mathrm{SH}$ from SS group 


\section{APPENDIX 5}

\section{TOTAL MYOSIN}

\section{Sample preparation}

One gram of raw, powdered sample was homogenized with $100 \mathrm{~mL}$ of cold deionized, distilled water using a Polytron homogenizer (Polytron PT10-35, Fisher Scientific Co.; Pittsburgh, PA) for 1 min (Srinivasan et al., 1997). Sample buffer (8 M urea; 2 M thiourea; 75 mM DTT; 3\% SDS; 0.05\% bromophenol blue; $0.05 \mathrm{M}$ Tris buffer, $\mathrm{pH}$ 6.8) was combined to the homogenate at 1:1 ratio to give a final protein concentration of approximately $1 \mathrm{mg} / \mathrm{mL}$.

\section{Sodium dodecyl sulfate, polyacrylamide gel electrophoresis (SDS-PAGE)}

A vertical slab gel system (Hoefer Scientific Instruments; San Francisco, CA) was used to prepare $0.75 \mathrm{~mm}$-thick gels. Ten microliters of the sample were loaded in alternating wells of a $3 \%$ stacking gel, and sample buffer was loaded in empty wells to minimize band diffusion. A $12 \%$ bis-acrylamide resolving gel was used to separate protein bands. Electrophoresis was conducted at a constant current of $20 \mathrm{~mA}$ per slab until the tracking dye reached the resolving gel, and the current was then increased to $30 \mathrm{~mA}$ per slab. Electrophoresis proceeded until the marker dye was $4 \mathrm{~cm}$ from the bottom of the gel. Gels were fixed in $10 \%(\mathrm{w} / \mathrm{v})$ trichloroacetic acid $(\mathrm{TCA})$ for $20 \mathrm{~min}$, stained in a $0.05 \%(\mathrm{w} / \mathrm{v})$ Coomassive brilliant blue G-250 (Eastman Kodak Co.; Rochester, NY), 50\% (v/v) methanol, and $9.2 \%(\mathrm{v} / \mathrm{v})$ glacial acetic acid solution for $4 \mathrm{~h}$. Gels were subsequently destained in a solution containing $10 \%(\mathrm{v} / \mathrm{v})$ methanol and $7.5 \%$ (v/v) glacial acetic acid until the background was clear. Destaining procedures 
for all gels were standardized. Ten $\mu \mathrm{L}$ of high (212-40 kDa) and low (31-2.5 kDa) molecular weight marker (Sigma Chemical Co.; St. Louis, MO) were loaded on the left side of each gel, and $5 \mu \mathrm{g}$ myosin standard (Sigma Chemical Co.; St. Louis, MO) were loaded on the right side of each gel. All other reagents used were analytical grade. Gel image was acquired under a video camera (Alpha Innotech Corporation; San Leandro, CA) using Fluochem ${ }^{\mathrm{TM}}$ program. Individual bands of myosin were magnified at $2 \mathrm{x}$. Total myosin is expressed as $\mathrm{mg} / \mathrm{g}$ muscle. 


\section{APPENDIX 6}

\section{DIFFERENTIAL SCANNING CALORIMETRY PROGRAM}

Liquid nitrogen cooling (LNCA) initial fill

1. Jump to $0.00^{\circ} \mathrm{C}$

2. Isothermal for $0.20 \mathrm{~min}$

Running experiment

1. External event 1

2. LNCA control standard

3. Equilibrate at $20.00^{\circ} \mathrm{C}$

4. External event 0

5. Ramp $10 \mathrm{C} / \mathrm{min}$ to $95.00^{\circ} \mathrm{C}$ 


\section{APPENDIX 7}

\section{ENDOGENOUS PROTEASE ACTIVITY}

\section{Chemicals}

1. Mcllvaine's buffer $\mathrm{pH} 6.5$

2. Azocasein (Sigma-Aldrich; St. Louis, MO): $10 \mathrm{mg} / \mathrm{mL}$ azocasein solution

3. $50 \%$ trichloroacetic acid (TCA) solution

4. $10 \mathrm{~N}$ sodium hydroxide solution $(\mathrm{NaOH}): 20 \mathrm{~g}$ made up to $50 \mathrm{~mL}$ with distilled water

\section{Crude enzyme extraction (CEE)}

Raw, powdered sample was blended with cold deionized, distilled water at a 1:1 ratio in a Stomacher 400 blender (Tekmar; Cincinnati, $\mathrm{OH})$ for 2 min. This slurry was then centrifuged for $30 \mathrm{~min}$ at $4^{\circ} \mathrm{C}$ in a Damon IEC B200A (870 head, $8 \times 50 \mathrm{~mL}$ tubes) refrigerated centrifuge (Fisher Scientific; Pittsburgh, PA) at $17500 \times$ g, as measured at the top of the centrifuge tube. The supernatant was collected and used as crude enzyme extract.

\section{Measurement of enzyme activity}

1. Mix $1.875 \mathrm{~mL}$ Mcllvaine's buffer with $1.125 \mathrm{~mL}$ azocasein solution and pre-incubate for $5 \mathrm{~min}$.

2. Add $0.75 \mathrm{~mL}$ of $\mathrm{CEE}$ and incubate the mixture in waterbath at $70^{\circ} \mathrm{C}$ for 1 h.

3. Add $0.6 \mathrm{~mL}$ of $50 \%$ TCA solution to stop the reaction and allow protein to precipitate for $15 \mathrm{~min}$. 
4. Transfer the mixture to $5-\mathrm{mL}$ plastic centrifuge tubes and centrifuge at $5000 x g$ for $15 \mathrm{~min}, 4^{\circ} \mathrm{C}$.

5. Pipette $2.4 \mathrm{~mL}$ of supernatant, add $0.18 \mathrm{~mL}$ of $10 \mathrm{~N} \mathrm{NaOH}$, and mix thoroughly.

6. After $15 \mathrm{~min}$, read absorbance at $450 \mathrm{~nm}$.

7. A sample blank, CEE is added at the end of incubation.

8. Enzyme activity is expressed as (Abs sample $\left.-A b s_{\text {blank }}\right)$. 
Macllvaine's buffer (Behringer, 1973)

1. $0.1 \mathrm{M}$ citric acid (anhydrous): $19.212 \mathrm{~g}$ made up to $1000 \mathrm{~mL}$ with distilled water.

2. $0.2 \mathrm{M}$ disodium phosphate (anhydrous): $28.396 \mathrm{~g}$ made up to $1000 \mathrm{~mL}$ with distilled water.

For desired $\mathrm{pH}$, mix correct amounts as indicated below. Total volume is $20 \mathrm{~mL}$.

\begin{tabular}{ccc}
\hline $\mathrm{pH}$ & Citric acid, $\mathrm{mL}$ & \multicolumn{2}{c}{ Disodium phosphate, $\mathrm{mL}$} \\
\hline 4.0 & 12.29 & 7.71 \\
4.5 & 10.92 & 9.08 \\
5.0 & 9.70 & 10.30 \\
5.5 & 8.63 & 11.37 \\
6.0 & 7.37 & 12.63 \\
6.5 & 5.80 & 14.20 \\
7.0 & 3.53 & 16.47 \\
7.5 & 1.55 & 18.45 \\
8.0 & 0.55 & 19.45 \\
\hline
\end{tabular}




\author{
Data xxx; input day storage $\$ x x x$; \\ Card; \\ Proc print; \\ Proc glm; classes day storage; \\ model $x x x=$ day storage; \\ Ismeans storage/pdiff; \\ run;
}

APPENDIX 8

STATISTICAL PROGRAM

FROZEN STORAGE EFFECTS FOR THE NO-SOAK CONTROL 


\section{STATISTICAL PROGRAM}

\section{FOR RESPONSES PRIOR TO FREEZING}

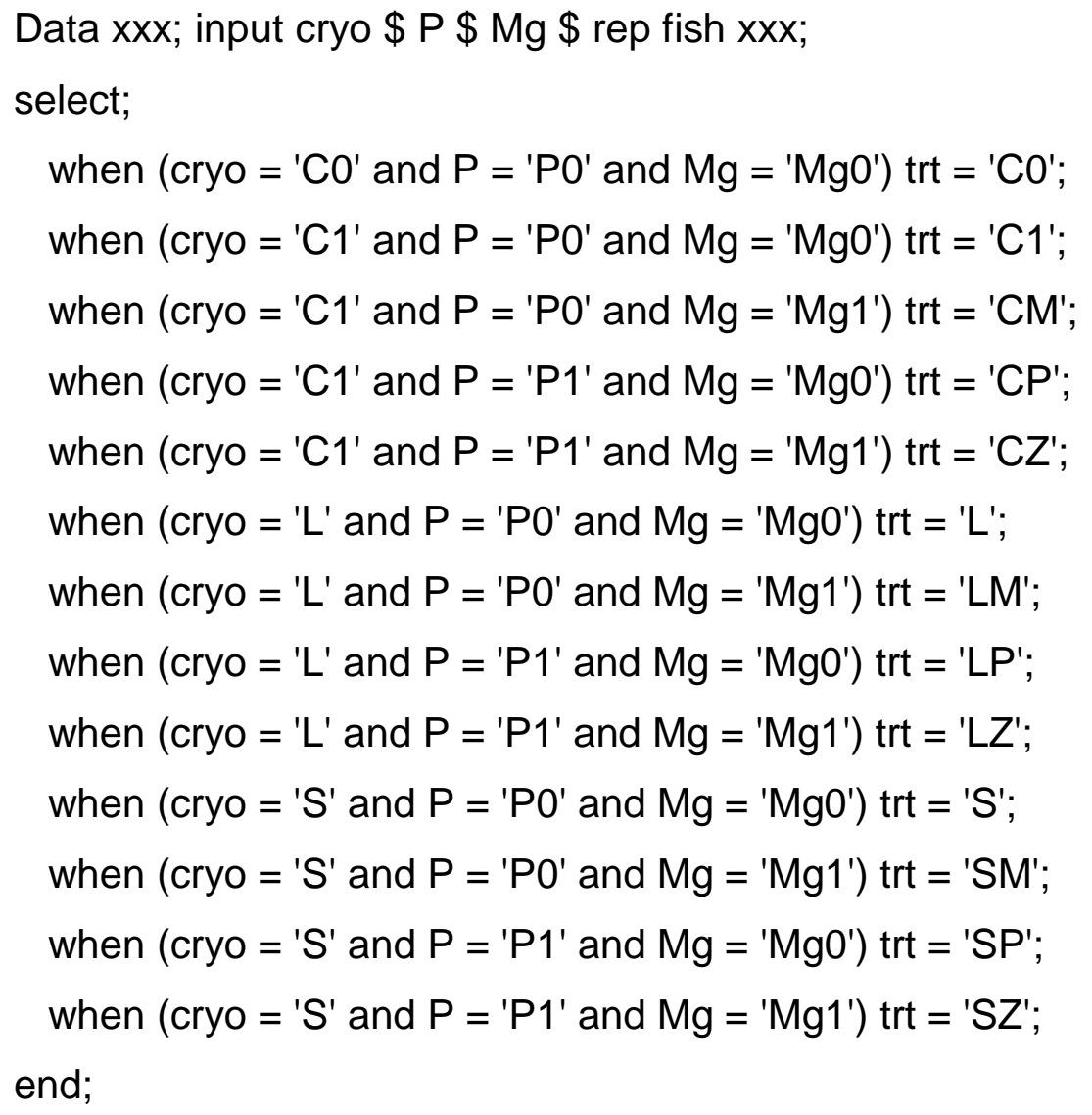

Proc print;

Proc glm; classes trt rep;

model $x x x=$ trt rep(trt);

Ismeans trt/pdiff $E=r e p(t r t)$;

run; 


\section{STATISTICAL PROGRAM}

\section{FOR RESPONSES FOLLOWING FROZEN STORAGE}

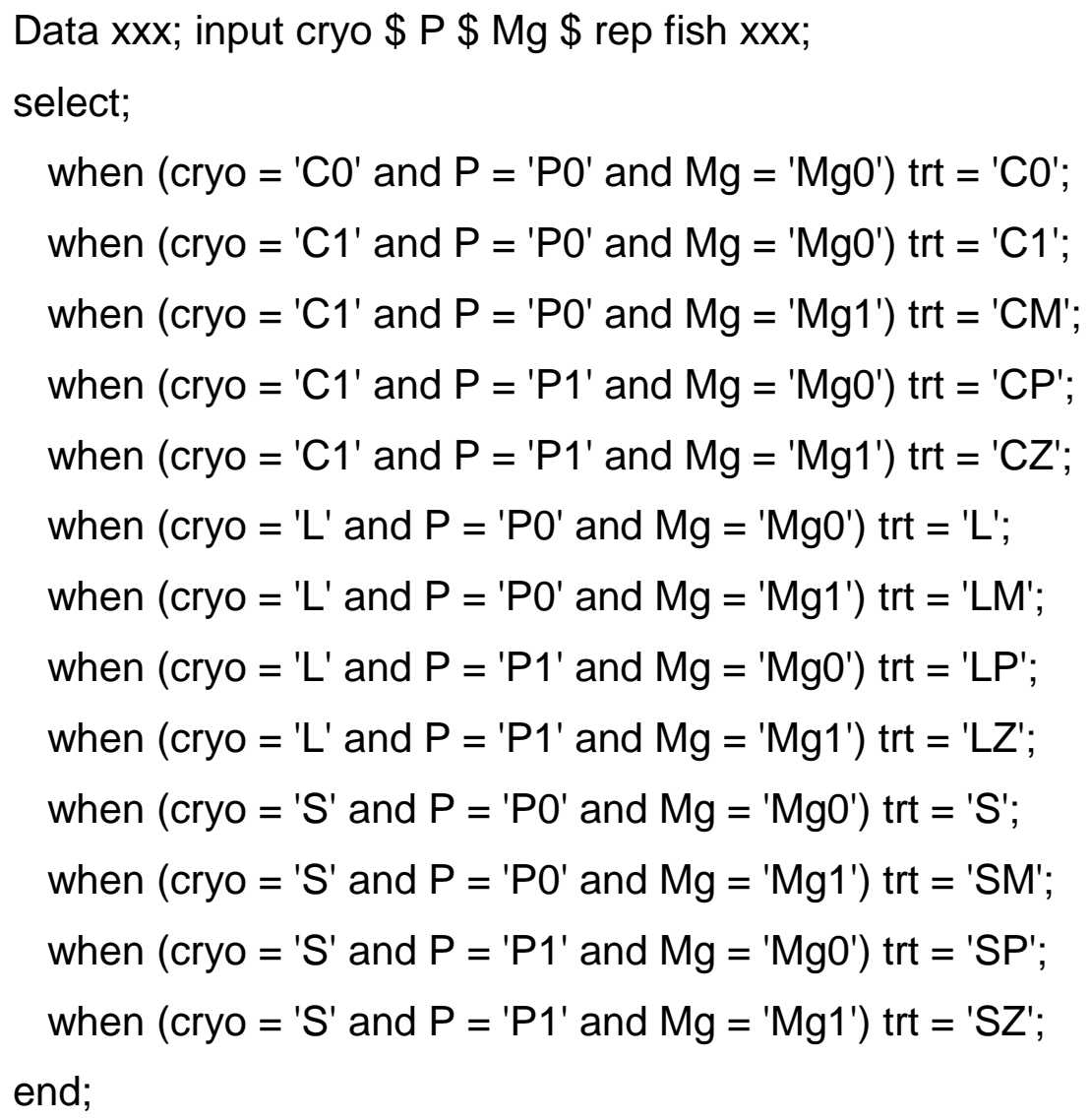

Cards;

Proc print;

Proc glm; classes trt rep;

model $x x x=$ trt rep(trt);

Ismeans trt/pdiff $E=r e p(t r t) ;$

run; 


\section{APPENDIX 9}

\section{ELECTROPHORETIC GEL PATTERNS}

\section{OF FISH MUSCLE PROTEIN FROM THE NO-SOAK CONTROL \\ OF FRESH AND FROZEN GROUPS}

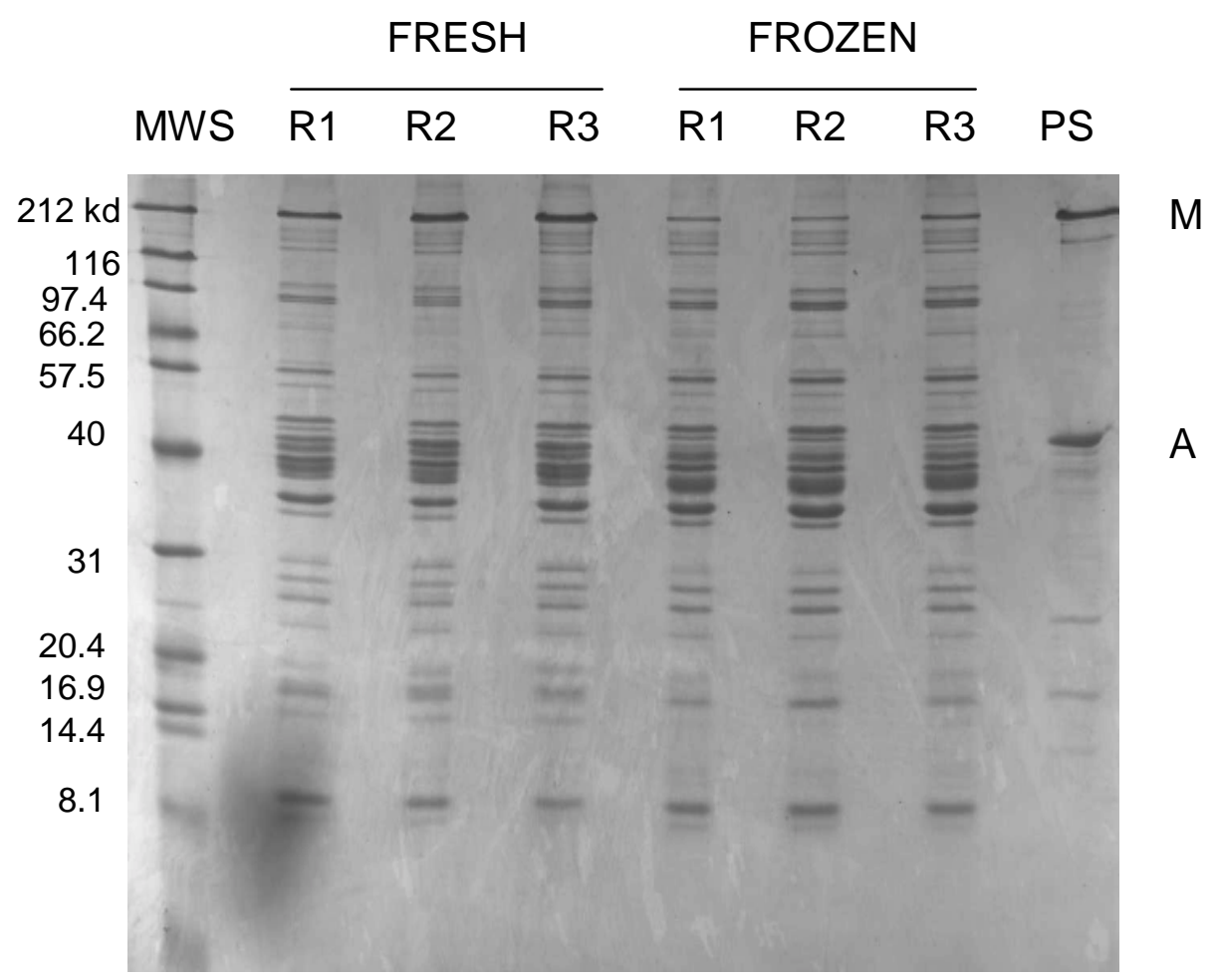

$\mathrm{R}=$ replication

MWS: molecular weight standards

PS: protein standards

M: myosin $5 \mu \mathrm{g}$

A: actin $5 \mu \mathrm{g}$ 